Florida International University FIU Digital Commons

FIU Electronic Theses and Dissertations

University Graduate School

2-17-2011

\title{
Para Subsistir Dignamente: Alberto Yarini and the Search for Cubanidad, 1882-1910
}

Mayra Beers

Florida International University, Mayra.Beers@fiu.edu

DOI: $10.25148 /$ etd.FI1 1042710

Follow this and additional works at: https://digitalcommons.fiu.edu/etd

\section{Recommended Citation}

Beers, Mayra, "Para Subsistir Dignamente: Alberto Yarini and the Search for Cubanidad, 1882-1910" (2011). FIU Electronic Theses and Dissertations. 370.

https://digitalcommons.fiu.edu/etd/370

This work is brought to you for free and open access by the University Graduate School at FIU Digital Commons. It has been accepted for inclusion in FIU Electronic Theses and Dissertations by an authorized administrator of FIU Digital Commons. For more information, please contact dcc@fiu.edu. 


\title{
FLORIDA INTERNATIONAL UNIVERSITY
}

Miami, Florida

PARA SUBSISTIR DIGNAMENTE:

ALBERTO YARINI AND THE SEARCH FOR CUBANIDAD, 1882-1910

\author{
A dissertation submitted in partial fulfillment of the \\ requirements for the degree of \\ DOCTOR OF PHILOSOPHY \\ in \\ HISTORY \\ by \\ Mayra Beers
}

2011 
To: Dean Kenneth Furton

College of Arts and Sciences

The dissertation, written by Mayra Beers, and entitled Para Subsistir Dignamente: Alberto Yarini and the Search for Cubanidad, 1882-1910, having been approved in respect to style and intellectual content, is referred to you for judgment.

We have read this dissertation and recommend that it be approved.

$\begin{array}{r}\hline \text { Thomas A. Breslin } \\ \hline \text { N. David Cook } \\ \hline \text { Mark D. Szuchman } \\ \hline \text { Sherry Johnson, Major Professor }\end{array}$

Date of Defense: February 17, 2011

The dissertation of Mayra Beers is approved.

\begin{tabular}{r} 
Dean Kenneth Furton \\
College of Arts and Sciences \\
\hline Interim Dean Kevin O’Shea \\
University Graduate School
\end{tabular}

Florida International University, 2011 


\section{DEDICATION}

I dedicate this dissertation to Randy, Jon and Josh.

Their love and support makes it all worthwhile. 


\section{ACKNOWLEDGMENTS}

Thank you is sometimes not a completely suitable phrase to express gratitude and appreciation. Even if inadequately expressed, I will try to recognize the work, support, and confidence that so many individuals have demonstrated to me over the course of my doctoral studies.

Thank you to the members of my committee, who read, counseled, pushed, and applauded. My thanks to Dr. N. David Cook who encouraged me to continue my graduate studies beyond the Masters level, provided unique opportunities for my professional development, and supported me every step of the way. Dr. Mark Szuchman, the first professor I met in the Department of History at FIU, challenged me to strive for excellence and supported my sometimes-delayed quest for a graduate degree; thanks also for all the signatures on graduate forms. Dr. Thomas Breslin, long before he was even on my committee, provided sage advice and candid encouragement; his comments made my work stronger and the degree seem achievable. Most of all, my thanks go to my Major Professor, Dr. Sherry Johnson, who saw the potential of my work long before I did and who provided countless opportunities for me to present, publish, and be recognized for my research. She has counseled, critiqued, scolded, pushed, and cheered me every step of the way through my graduate studies and, in the process, has become a true mentor and friend. From the beginning, she showed confidence in my abilities to complete my dissertation with excellence and encouraged me, sometimes with a stern hand, to achieve my goal even when I had given up hope of ever doing so. Thank you Dr. Johnson. I sincerely owe a debt of gratitude to each member of my committee for their respect and labors on my behalf. 
My heartfelt thanks to Dr. Modesto Maidique for his encouragement and for the opportunity I had to learn from him every day over the past fifteen years. His example of leadership and the countless opportunities for my professional development he provided have both stretched and strengthened my academic and professional career.

My thanks also go out to Elena Maubrey who in 1992 encouraged me to take the GRE and to pursue my dreams of obtaining a graduate degree when it seemed but a faint glimmer. Thanks also to Kristyn, Steven, Diana and Hayat for their support and assistance in completing the administrative process.

For their financial and scholarly support my thanks go to the faculty and staff of the Latin American and Caribbean Center and the Cuban Research Institute at Florida International University. I wish to thank my colleagues in Cuba who helped me comb the archives for clues and shared their work with me. I will not forget their kindness.

My thanks also to Dr. Albert Dotson, Dr. Paul Gallagher, the staffs at the Center for Leadership and the Office of the President at FIU who all knew I would someday be Dr. Beers and told me so often.

To my dear friend Roberto Pacheco, who read my work countless times, shared his knowledge, provided inspiration, expanded my intellectual horizons, and helped me so very much, thank you from the bottom of my heart.

Most of all I must say thank you to my family, my husband Randy and sons Jonathan and Joshua. Thank you for loving me all the way through this process. You put up with a lot to allow me to finish what I started. 


\title{
ABSTRACT OF THE DISSERTATION
}

PARA SUBSISTIR DIGNAMENTE:

ALBERTO YARINI AND THE SEARCH FOR CUBANIDAD, 1882-1910

\author{
by \\ Mayra Beers \\ Florida International University, 2011 \\ Miami, Florida \\ Professor M. Sherry Johnson, Major Professor
}

This study looks at the broader transformations in Cuban history through the case study of a single, yet symbolic, man, and proposes a new paradigm for understanding the dynamics of Cuban society and culture. It also examines the implications for Cuba's aspiring national identity at the turn of the twentieth century, by detailing the interplay between fact and fiction in the story of Alberto Yarini: elite born; well-educated; politically and socially well-connected; powerful; and celebrated Cuban racketeer and chulo (pimp).

Yarini was described as vibrant and triumphant at a time when other nationbuilding forces in Cuba were weak and ambivalent. A century after his dramatic death, Yarini became the quintessential public man in Cuban lore who symbolized a cubanidad (Cuban national identity) not defined in terms of the ideological hegemony of class, race, or gender, and who through his actions dispelled the ambivalence that plagued Cuban nationalism.

Using archival documents, contemporary newspaper accounts, court records, memoirs, and published works, this study analyzes the confluence of national events and 
individual action in the formation of Cuban national identity. It contends that for Cuba, the failure of nation-building experiments resulted in an ambivalent national identity based on failed philosophical and political ideals of equality and prosperity. These ideals played out within the context of the realities of racial discrimination, political dissonance, and class and gender barriers. Instead of a cohesive sense of national character, for Cubans the result was a competing set of identities including a populist version that was defined through identification with antitypes and pseudo-heroes such as Alberto Yarini y Ponce de León (1882-1910), a rising politician and celebrated chulo of the early republic. The telling and retelling of his story has given rise to what has been termed the island nation's first national myth - one that continues to evolve and grow in the twenty-first century. For many Cubans, the Yarini antitype provided an idealized national identity which in many ways was — and many argue continues to be — the expression of an elusive and ambivalent cubanidad. 
I. THE EXPRESSION OF PUBLIC DREAMS: ALBERTO YARINI AND CUBANIDAD ........................................................... 1

A Nation without a State .................................................. 4

From Evolutionaries to Revolutionaries ................................ 8

Raceless Cubanidad ....................................................... 17

Public Dreams ........................................................ 23

Conclusion ........................................................... 28

II. LA IMPENETRABLE ÉGIDA DE MI PERSONA: FROM TUSCANY TO HAVANA

Il Regno d'Italia ....................................................... 34

Hacer la America ....................................................... 37

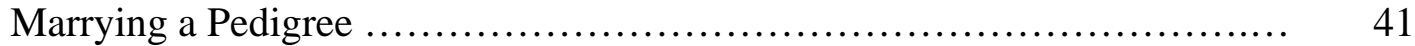

Ponce de León .......................................................... 53

Move to Havana ....................................................... 5

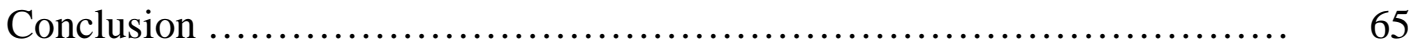

III. LA PATRIA PEQUEÑA: HAVANA ....................................... 68

Northern Suitors ........................................................ $\quad 71$

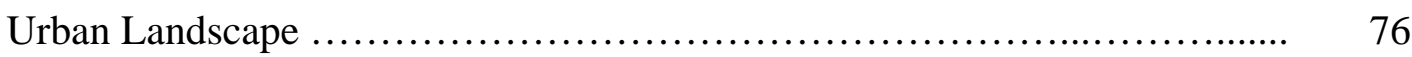

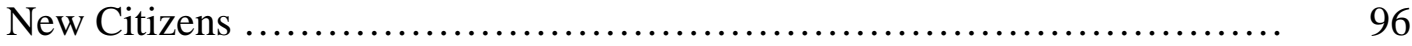

Conclusion ...................................................... 98

IV. AMBITION ATTRACTED HIM TO OUR BARRIO: THE SAN ISIDRO

DISTRICT ............................................................. 100

The Barrio ......................................................... 100

Prostitution, Abakuás, and Bolita ........................................... 103

How to become King ................................................. 130

Conclusion .............................................................. 132

V. $\quad$ PARA SUBSISTIR DIGNAMENTE: YARINI THE PATRIOT ............... 135

Ambivalent Nationhood ................................................ 136

A New Republic ............................................................ 141

Masculinity and Nationhood ............................................... 146

The Spectacle of Masculinity ........................................... 148

Hegemonic Masculinity ........................................... 160

The American ..................................................... 170

The Cuban .................................................................. 176

Conclusion .............................................................. 179 
VI. NUNCA OLVIDARE AQUEL ENTIERRO: MOURNING, PUBLIC SPACE, AND CUBANIDAD ............................................ 182

Conservatives and Liberals ............................................ 186

Apaches and Guayabitos............................................... 188

The Ambush .................................................... 192

Short-term Repercussions ........................................... 215

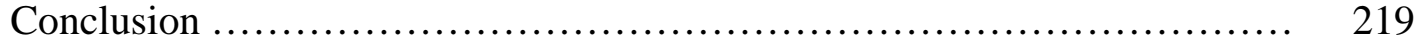

VII. EL CHULO QUE SOÑO SER PRESIDENTE:

THE BIRTH OF A CUBAN MYTH ................................... 221

The Martyr of San Isidro ............................................ 222

Long-term Implications .......................................... 223

Myths and Memory.................................................. 237

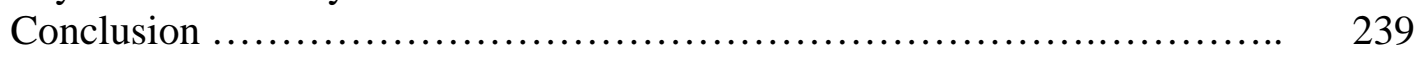

Epilogue ......................................................... 244

LIST OF REFERENCES ............................................. 245

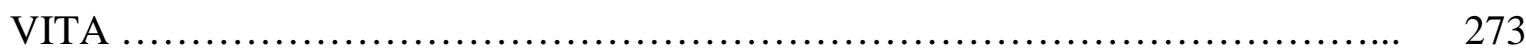




\section{LIST OF FIGURES}

FIGURE

PAGE

1. Cirilo Yarini y Ponce de León, Co-founder of the School of Dental Surgery, University of Havana .................................... 61

2. Family Tree for Alberto Yarini y Ponce de Leon .................... 67

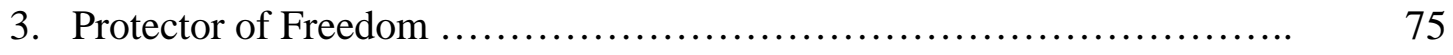

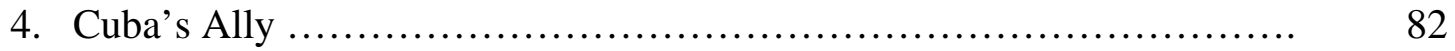

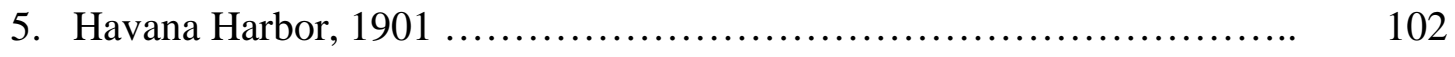

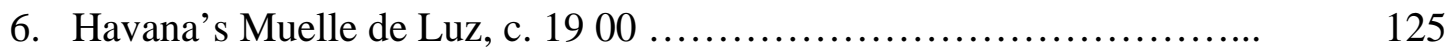

7. Acera de Louvre Colonnade, c. 1910 ................................. 150

8. Parque Central .............................................. 152

9. The Funeral Procession for Alberto Yarini ........................... 183

10. Photograph of Alberto Yarini ................................... 185

11. Front Page of La Caricatura, 25 November 1910 .......................... 211 


\title{
CHAPTER I
}

\section{THE EXPRESSION OF PUBLIC DREAMS:}

\author{
ALBERTO YARINI AND CUBANIDAD \\ [Public dreams are] the gap we open for ourselves \\ between the way we live and what we want. ${ }^{1}$
}

Ambivalence. For more than five decades, historians and pundits have often framed Cuban national identity (cubanidad) in terms of its ambivalence: a "classless" society with a stratified and elitist social order; a "raceless" society that denied political rights to its Afro-Cuban "patriots” and extinguished their political organizing; and a modern society that embraced a primitive contrapunteo. ${ }^{2}$

For sociologists, ambivalence represents the unique co-existence of contradictory yet independent impulses that lead a society to behave with uncertainty. This dual consciousness thwarts the ability of a group to act in a cohesive manner toward a

${ }^{1}$ Frances Leviston, “Scandinavia,” in Public Dream (London: Picador, 2007), 76.

2 Made famous by Fernando Ortiz (Contrapunteo cubano del tabaco y el azúcar [Consejo Nacional de Cuba, 1963]), the term is commonly used as a folk-style cadenced, confrontational, and a-harmonical improvisation, practiced by guajiros (peasants) and "poetas" a type of improvisational rhymer/poet. The contrapunteo is usually performed in informal public settings; its lyrics generally filled with innuendo and double-entendre and provide a means to get at a rival while being able to enjoy drinks with him later in the evening. The "punto guajiro" is a type of contrapunteo. 
common goal. ${ }^{3}$ Nevertheless, emerging nations, although often mired in ambivalence, at times achieve collective objectives through indirect, yet effective, means. For others, the trajectory proves more elusive.

In Ambivalent Conquests, an analysis of conquerors and conquered in the Yucatan peninsula of Mexico between 1517 and 1570, Inga Clendinnen argues that the Maya’s world-view provided the cultural resilience that allowed them to sustain elements of their traditional order while giving a nod to Spanish hegemonic institutions. ${ }^{4}$ Citing the work of labor historian, E.P. Thompson (The Making of the English Working Class), she proposes that discerning what people intend and want can be gleaned from what they say,

${ }^{3}$ Gordon Marshall, ed., Oxford Dictionary of Sociology, (Oxford: Oxford University Press, 1994). The dual consciousness thesis argues that a colonized or subordinate class must embrace two cultural identities each with a distinct set of beliefs or values which are often inconsistent. This results in an ambivalent attitude to some of the central institutions in society. For a discussion of dual consciousness, see Frantz Fanon, Black Skin, White Masks, translated by Richard Philcox (New York: Grove Press, 2008). Double-consciousness, the concept that an individual sees him/herself through the eyes of others and therefore has an ambivalent self-identity was discussed by W.E.B. DuBois in The Souls of Black Folk: Essays and Sketches (Chicago: A.C. McClurg and Co., 1903), 3.

${ }^{4}$ Inga Clendinnen, Ambivalent Conquests: Maya and Spaniard in Yucatan, 15171570 (New York: Cambridge University Press, 2003). Also see, Miguel León-Portilla, The Broken Spears: The Aztec Account of the Conquest of Mexico, (Boston: Beacon Press, 1992); Irene Silverblatt, Moon, Sun, and Witches: Gender Ideologies and Class in Inca and Colonial Peru (Princeton, NJ: Princeton University Press, 1987); and Tzvetan Todorov The Conquest of America :The Question of the Other, trans. Richard Howard (New York: Harper and Row, 1999). For a discussion of the role of symbols in constructing public meaning, the seminal work of symbolic anthropology is Clifford Geertz, The Interpretation of Cultures (New York: Basic Books, 1973), 89. Geertz outlines culture as "a system of inherited conceptions expressed in symbolic forms by means of which people communicate, perpetuate, and develop their knowledge about and attitudes toward life." 
"but even more from what they do." ${ }^{5}$ In the same way, Cuban national identity can only partially be defined by the words of its philosophers and politicians; instead, it has been shaped and transmitted through ambivalent populist interpretations and actions.

This study contends that for Cuba, the failure of nation-building experiments resulted in an ambivalent national identity based on failed philosophical and political ideals of equality and prosperity. These played out in the midst of the realities of racial discrimination, political dissonance, and class and gender barriers. Instead of a cohesive sense of nationalism, the result was a competing set of national identities largely built around personalism. These included a populist version that was defined through identification with antitypes and pseudo-heroes such as Alberto Yarini y Ponce de León (1882-1910), a rising politician and celebrated chulo (pimp) of the early republic whose exploits and charisma captured Cubans' imagination. ${ }^{6}$ The telling and retelling of his story has given rise to what has been termed the island nation's first national myth - one that continues to evolve in the twenty-first century. For many Cubans, the Yarini antitype provided an idealized national identity which in many ways was-and many argue continues to be - the expression of an elusive public dream of cubanidad: "the gap we open for ourselves/between the way we live and what we want."

\section{${ }^{5}$ Clendinnen, Ambivalent Conquests , xiv; 132.}

${ }^{6}$ One popular definition of the term chulo proposes it is a Spanish version of the word knife in "caló" the language of gypsies; Ramón Fernández Larrea, "Carta a Yarini," Encuentro, 24 (Spring 2002): 125-128, (arch1.cubaencuentro.com/pdfs/24/24rfl125.pdf), downloaded 14 March 2009.

${ }^{7}$ Quote from Leviston's “Scandinavia.” For a discussion of mythology as an expression of public dreams, see Deborah Garwood, "Myth as Public Dream: The 


\section{A Nation without a State}

But what did Cubans want? The terms nationalism and national identity imply the appropriation of a collective culture whether imagined or real; this proved an elusive undertaking for Cubans. A review of the historiography of nation-building in Cuba provides numerous refraction points to examine this phenomenon. Historians have long looked to answer this question and have argued that Cuba's aspirations for nationhood were significantly different than those of the rest of Latin America. Cuba was a nation long before it became a state; it experienced an early awakening of national consciousness that did not or could not find a voice. ${ }^{8}$

For Cuba, the concept of nation, although identified early, had no moorings on which to anchor its aspirations. Benedict Anderson has posited the power of the imagined community, the concept of nation constructed as a mental image of an affinity held by the individuals who see themselves as belonging to that group. A nation, Anderson proposes, "is imagined because the members of even the smallest nation will never know most of their fellow-members, meet them, or even hear of them, yet in the minds of each lives the

Metamorphosis of Mary Zimmerman's Metamorphoses, ” Journal of Performance and Art 25, no. 1 (January 2003): 69-78.

8 Three key studies with differing perspectives on the development of a shared Cuban identity include Josef Opatrny, Antecedentes históricos de la formación de la nación cubana (Prague: Universidad Carolina, 1986) which presents annexationist discourse of the 1850s as a foundational movement in the formation of Cuban national identity. For a discussion of subtle and overt U.S. cultural influences on the developing of Cuban national identity (from the 1850s through the Cuban revolution of 1959), see Louis A. Perez, On Becoming Cuban: Identity, Nationality, and Culture (Chapel Hill: University of North Carolina Press, 1999). 
image of their communion." ${ }^{9}$ As in the case for Cuba, the group could have a high degree of national consciousness but lack an overt ideology, "let alone a political movement on behalf of the nation." ${ }^{10}$ Thus, Cuba faltered in its search for a consciousness of nation. Lacking a native population that provided linkages to a unified past, without a long-established aristocracy or a transcendent religious culture, and with a transient, opportunistic bourgeoisie, Cuba was a nation continuously searching for an identity.

During Cuba’s protracted struggle for independence from Spain (1868-1898), there emerged no single revolutionary class that could provide a national vision. Built on the expediencies of independence struggles, Cuba’s preeminent philosopher/warrior, José Martí, promulgated a vision of a "nation for all” that could unite Cubans against Spanish control and was somewhat effective during the last Cuban war for Independence (18951898). In the wake of Martí's death, that vision collapsed in the realities of the early republic. ${ }^{11}$ In The Myth of José Martí, Lillian Guerra argues that from 1895-1921 Cuban

\footnotetext{
${ }^{9}$ Benedict Anderson, Imagined Communities: Reflections on the Origin and Spread of Nationalism (New York: Verso, 1991), 37-46, 224. For a broad treatment of issues of nationalism see John Hutchinson and Anthony Smith, eds., Nationalism (New York: Oxford University Press, 1994).

${ }^{10}$ Anthony D. Smith, Nations and Nationalism in a Global Era (Cambridge: Polity Press, 2002), 5.

${ }^{11}$ Dionisio Poey Baro, “'Race’ and Anti-Racism in Jose Marti’s 'Mi Raza,’” Contributions in Black Studies 12 (1994): 57-58. For discussions of the polarity that defined Cuban politics during 1895-1921, see Lillian Guerra, The Myth of José Martí (Chapel Hill: University of North Carolina Press, 2005); John Kirk, José Martí: Mentor of the Cuban Nation (Gainesville, FL: University of Press of Florida, 1983); Rafael Rojas, José Martí: La invención de Cuba (Madrid: Editorial Colibri, 2000); and Marial Iglesias, “José Martí: mito legitimación y símbolo,” in Diez nuevas miradas a la historia
} 
nationalists appropriated Martís vision of "social unity” to formulate competing ideologies of nationhood. Some used Martí and versions of his rhetoric to promote foreign investment and values; others looked to government to enact social change; while others rallied to build a democratic society that would enact social and economic justice. In each case, the relationship with the United States was cast in a different light: as benefactor, oppressor, or model. Because his rhetoric was so "porous" and adaptable, Martí became the one issue on which all three factions agreed and the one factor they used to discredit competing paradigms of nation. Guerra further argues that the result was a lack of consensus that plagued Cuba not only in the early years of the Republic, but which continued throughout the twentieth century. The roots of failed nationalism, however, had long antecedents in Cuba's pre-republican years. ${ }^{12}$

Twentieth-century historians have marshaled textual and data analysis to uncover the driving forces that, for almost two centuries, propelled Cuba's history as a phenomenon of an ambivalent, ever-emerging nationhood. Using new methodologies and sources opened by the "Triumph of the Revolution," the victory of Fidel Castro's grass roots revolution that overthrew the Batista government in 1959, historians of Cuba challenged the traditional heroic, constitutional histories and addressed questions of national identity through the prism of race, economics, and cultural adaptation and resistance. Their research produced a rich literature that in many aspects, rather than clarifying the issues,

de Cuba, Jose A. Piqueras, ed., (Castello de la Plana, Spain: Universitat Jaume I, 1998), 179-201.

${ }^{12}$ See C.A.M. Hennessy, “The Roots of Cuban Nationalism,” International Affairs 39, no. 3 (1963): 345-59. 
further reinforced the dilemma of the contradictory nature of Cuban national identity - a contradiction of actions, language, and texts. In turn, these studies revealed a postindependence strain of national identity that relied heavily on official constructs of race, gender and social status and which ultimately failed. In this dissertation I explore the nexus of culture and leadership which created one popular construct that may have actually worked in establishing a shared concept of a Cuban nation.

Beginning in the 1960s, historical inquiries surrounding the political and economic relations between Cuba and the U.S. took center stage - perhaps, in part, in an attempt to answer for U.S. historians "how it [the Cuban Revolution] could happen.” Historical scholarship on U.S./Cuba/Spain national dynamics and trends surrounding the birth of the Cuban republic in 1902 received significant attention. ${ }^{13}$ Couched in issues of social structures, race, and gender, historians provided explanations for the ambivalence of Cuban nationhood and its struggle to be "free" as manifested in three distinct ideologies closely paralleling Guerra's triumvirate of nationalism: the autonomist, annexationist, and independence and self-determination movements and the latter's tarnishing on issues of race.

Each of these historical political movements received its energy from the social networks that aligned within and among the three camps. The "independents," certainly, have received the most attention, but much can be learned from reflecting on the ideological

${ }^{13}$ For examples of ideological interpretation of United-States-Cuban relations and the Castro Revolution, see Jules R. Benjamin, The United States and the Origins of the Cuban Revolution (Princeton: Princeton University Press, 1990); and Louis A. Perez, Jr., Essays on Cuban History: Historiography and Research (Gainesville: University Press of Florida, 1995). 
constructs of the individuals who supported each of these divergent views of a Cuban state yet failed to bring about an imagined community of nation. For historians, the embrace or rejection of these socio-political paradigms served both as ideological "bully pulpits” and as insightful forays into a nation’s dense past. Much as Martí was appropriated by the republican nationalists in their struggle for supremacy, prerevolutionary factions were polarized along socio-economic lines that fostered ambivalence and prevented the formation of a transcendent cubanidad.

\section{From “Evolutionaries” to Revolutionaries}

Traditionally, Cuba’s historiography has provided a rich literature on the nineteenth and twentieth centuries, largely focused on the production, expansion, and collapse of the sugar industry and slavery, and Cuban opposition to colonial rule. The foundations of these movements have received much less deliberation by historians. Recently, a few scholars such as Sherry Johnson and Larry Jensen, have positioned criollo social frameworks within Spanish colonial power structures and have examined the development of political, social, and patronage networks on the island. In her study of eighteenth century military immigration and reforms, for example, Johnson argues that these critical linkages provide a means for explaining the Cuban military’s loyalty to Spain as opposed to the actions of their Creole counterparts across Latin America during nineteenth century independence struggles. The loyalty of this sector, she argues, helped thwart independence movements in Cuba until the end of the century and provided a point of consensus for loyalist action. Jensen, in turn, analyzes nineteenth-century periodicals and the editorials of the "sugarocracy” to explain the elites' ardent loyalty to 
Spain in the midst of imperial disintegration. ${ }^{14}$ The fear of economic loss, he argues, far outweighed sympathy for independence and actively sought to subdue it. Studies such as these highlight the powerful and complex social networks that worked against rallying the long-term elements of cubanidad in the face of immediate personal and economic benefits for criollo landowners. Yet the status quo would not hold for long.

By the mid-nineteenth century, a more organized Cuban bourgeoisie looked for a voice that would represent its interests. The Autonomista movement was led by Cuba's urban, professional elites who rejected talk of both annexation and independence. For two decades (1878-1898) many Cubans ardently believed that "evolution and not revolution" was the best route to self-government and a Cuban nation. ${ }^{15}$ However, after the Peace of Zanjón in 1878 which ended Cuba's first abortive attempt at independence, a demoralized Cuban creole elite and a ruined bourgeoisie were financially broken by the post-war economic chaos, and many left Cuba altogether, especially for the United States. Those who stayed behind, a group representing the Cuban middle-class lawyers, doctors, mid-size property owners, and other professionals— organized the

${ }^{14}$ Sherry Johnson, The Social Transformation of Eighteenth-Century Cuba (Gainesville: University of Florida Press, 2001). Larry Jensen, Children of Colonial Despotism: Press, Politics, and Culture in Cuba, 1790-1840 (Gainesville: University of Florida Press, 1998). See also, Alan Keuthe, Cuba, 1753-1815: Crown, Military and Society (Knoxville: University of Tennessee, 1986); and Maria Dolores Gonzalez-Ripoll Navarro, Cuba, La Isla de los Ensayos: Cultura y Sociedad, 1790-1815 (Madrid: Centro de Humanidades, 1999).

${ }^{15}$ J.C.M. Oglesby, "The Cuban Autonomist Movement's Perception of Canada, 1865-1898: Its Implication,” The Americas, 47, no. 4 ( April 1992): 445-61. See also Benjamin, The United States and the Origins of the Cuban Revolution; and Louis A. Pérez, Jr., Cuba Between Empires, 1878-1902 (Pittsburgh: University of Pittsburgh Press, 1983). 
Cuban Liberal Party (PLC) in August 1878 and established the group’s official journal, El Triunfo. ${ }^{16}$

During the 1880s as the struggle for recognition from Spain continued, autonomistas focused on increasing their representation in the Spanish parliament (Cortes) and were often faced with disillusionment, when their voices went largely unheard by the metropolis or their compatriots. By the end of the century, autonomistas envisioned Cuba as a self-governing colony within the Spanish empire - operating a form of government modeled after what Canada had established within the British Empire. It would take a compliant Spanish crown to authorize such a move. After two previous "wars for independence" and nearly three years of insurrection and stalemate on the island beginning in 1895, by 1897 the Autonomista solution became a more plausible arrangement for Spain and in January 1898 an autonomist provisional government was established in Cuba.

While the literature on the Cuban autonomy movement is limited and has not received recent scrutiny, In Cuba, the Pursuit of Freedom, Hugh Thomas suggests that given the opportunity, the autonomistas may have actually succeeded—at least in establishing a government if not in coalescing cubanidad. ${ }^{17}$ Furthermore, in his study of the Cuban

${ }^{16}$ See Juan Gualberto Gómez, La cuestión de Cuba en 1884, Historia y Soluciones de los partidos cubanos (Madrid: Aurelio J. Alaria, 1885). On 2 July 1878, El Triunfo reported the journal's founders included hacendados (owners of large landed estates), lawyers, doctors, journalists, etc. Ogelsby, "The Cuban Autonomist Movement's Perception of Canada," 449.

${ }^{17}$ Hugh Thomas, Cuba, Or, The Pursuit of Freedom (New York: Harper and Row, 1971). See also, Raymond Carr, Spain, 1808-1938 (Oxford: Clarenden Press, 1966). 
autonomistas' embrace of Canada's experiment in autonomy, J.C. Ogelsby suggests that because of eventual imposed independence in 1902, Cuba "never had a chance to evolve into an independent and free nation.” Cubans, he argues, were not given the opportunity to "evolve out of a colonial sensibility" and therefore, became "trapped in a revolutionary tradition that is, paradoxically, utterly colonial." ${ }^{18}$ Rafael Tarrago, in the 92 page introduction to his anthology of documents on Cuban political life covering the years 1513 to 1898, supports the Ogelsby study adding that, if Cubans had accepted an autonomous regime, U.S. intervention and occupation would not have happened and the transformation of Cuba into a U.S. client state would have been prevented. He contends that the failure of the autonomista movement resulted in a post-independence tradition of political violence and disparate national goals. ${ }^{19}$

If autonomistas were not given a chance to succeed, Annexationists earned a disproportionate amount of credit for their influence. Although too little studied by historians, this sector at first supported a Spanish alliance and after U.S. occupation sought to exchange the rule of one colonial power for another. An ever-current question for more than two centuries, issues of annexation surfaced again and again in Cuban political rhetoric. For example, on October 18, 1897, an editorial in the New York Times reported on “The New Cuban Question.” Reflecting on the Spanish government’s decision to allow an Autonomist provisional government to be installed in Havana as a

${ }^{18}$ Oglesby, “The Cuban Autonomist Movement’s Perception of Canada," 46.

${ }^{19}$ Rafael E. Tarrago, Experiencia de los cubanos en la Cuba Española, 15121898 (Barcelona: Puvill Libros, 1995). See also, Rafael Tarrago, “The Road to Santiago: Cuban Separatism and United States Americanism and How they Converged in 1898,” Iberoamericana, No. 3 ( 2001): 61-89. 
way to defuse the insurrection in Cuba, the Times suggested that "Cubans of prominence" from every province were organizing to secure a future "most likely to further their interests and those of the island in general," noting that prominent Cubans believed that only the U.S. government could "guarantee peace in Cuba and the protection of life and property," the elites' definition of cubanidad. While the annexationist movement may have peaked during the mid-nineteenth century, it was continuously invoked by Cubans fearing Spanish peninsular control in the frenzy of 1898 and in the post-occupation uncertainty of self-rule. $^{20}$

Historians have sparingly looked at the "pull" factor of Cuban annexationist trends and how U.S. hegemony may have been encouraged and accepted by Cubans on the island before 1898. The topic has nevertheless produced several important historical inquiries. Philip Foner, for example, argued that by 1898 "annexationists constituted a distinct [but vocal] minority in Cuba. The vast majority of the Cubans insisted on independence.”21

${ }^{20}$ Annexationism continued to echo in Cuba's political rhetoric a century later. "Castro Warns Young Cubans of U.S. Annexationist Aims," 16 August 2007, Agencia EFE, http://news.notiemail.com, (Accessed 16 November 2009). See also Graciella Cruz-Taura, "Annexation and national identity: Cuba's Mid-Nineteenth-Century Debate," Cuban Studies 27 (1997): 90-106.

${ }^{21}$ In "The Collapse of the Cuban Planter Class," Louis A. Pérez argues that Cuban independence was the last of series of events that effectively toppled the planter class. In its place emerged a bourgeoisie that looked to U.S. largess to guarantee national political and economic stability and thus promoted U.S. hegemony; Louis A. Pérez, Jr., "The Collapse of the Cuban Planter Class," Inter-American Economic Affairs 36, no. 3 (Winter 1982): 3-22 and Philip Foner, A History of Cuba and its Relations with the U.S. (New York: International Publishers, 1962), 29-30. For an analysis dispelling the international euphoria surrounding the Castro Revolution, see Theodore Draper, Castro's Revolution, Myths and Realities (New York: F. A. Praeger, 1962); Castroism, Theory and Practice (New York: F. A. Praeger, 1965); “Castro's Cuba; a revolution betrayed?” The New Leader, 5 June 1961; and "Cuba and United States policy," The New Leader, March 1961. For a short bibliography of critical analyses of the Cuban Revolution, see Sam 
Annexationist ideologies were most prevalent among the planter elite who looked to the U.S. as a solution to thwart internal and international abolitionism. ${ }^{22}$ A more recent analysis of annexationism was offered by Josef Opatrny, who argues that the annexationist movement, while never espoused by intellectuals in Cuba, was a necessary first step in the evolution of a separatist ethos. According to Opatrny, with little popular support, the annexationist cause never gained a strong following, yet it provided the counterpoint to the rallying cry for independence and was a critical first step to legitimizing armed insurrection. By and large, annexationism studies have focused on U.S. intentions rather than on patriotic sentiment and opportunities for Cubans; Opatrny provides a different view of the economic advantages and the social stability envisioned by Cuban proponents of annexation as a unifying national vision. ${ }^{23}$

By 1898, popular expressions of annexationist sentiment joined the cacophony of political alternatives for Cubans. For example, in 1901 more than 100,000 Cubans (both spectators and participants) including the "ultra-Cuban element” gathered at a demonstration led by Juan Gualberto Gómez to rally in support of U.S. annexation.

Dolgoff, The Cuban Revolution: A Critical Perspective (Montreal: Black Rose Books, 1976), 189-91.

${ }^{22}$ Robert May, The Southern Dream of a Caribbean Empire (Baton Rouge: Louisiana State University Press, 1973).

23 Josef Opatrny, U.S. Expansionism and Cuban Annexationism in the 1850s (Lewiston, NY: E. Mellen Press, 1993). Cuba's first national elections in 1900 proved a resounding defeat for annexationists. The revolutionaries (Cuban National Party) won almost every election that year and delivered a serious blow to the moneyed and influential members of the annexationist Democratic Union Party. Eee Leslie Bethell, ed., Cuba: A Short History (Cambridge, MA: Cambridge University Press, 1993); Edwin F. Atkins, Sixty Years in Cuba: Reminiscences of Edwin F. Atkins (Cambridge, MA: Riverside Press, 1926; reprint New York: Arno Press, 1980). 
Additionally, Señor Marcane, a “leading lawyer” in Santiago in western Cuba, addressed a crowd of more than 8000 men exhorting them to recognize that their interests were inextricably tied to those of the U.S. These demonstrations were regarded as a clarion call that would lead to the eventual formation of an annexation party with a view to unify Cuban populist sentiment. ${ }^{24}$ Three weeks later, led by senators Pablo Desvernine and Antonio González Lanuza and with the support of the Marquis de Montoro, a petition asking for annexation circulated throughout the city of Santiago. ${ }^{25}$ By the end of the year, merchants and planters faced worsening economic conditions with 100 pounds of sugar reportedly selling at $\$ .57$ less than it cost to produce. ${ }^{26}$ With little redress, they sought to meet with Theodore Roosevelt to ask his support in annexation, claiming the alternative was financial ruin. ${ }^{27}$ The divisions in official ideology were evident when the Captain of the Port of Havana, the American, Lucien Young, who was a strong supporter of annexation, commented that "Cubans who amount to anything want Annexation. Only

${ }^{24}$ Massachusetts Historical Society (hereafter MHS), Edwin F. Atkins Collection, Scrapbooks, newspaper clipping, 3 October 1901. Transcripts and notes from the Edwin F. Atkins Collection courtesy of Dr. Sherry Johnson.

${ }^{25}$ MHS, Edwin F. Atkins Collection, Scrapbooks, newspaper clipping, 22 October 1901.

${ }^{26}$ The newspaper accounts report that sugar sold for $\$ 3.1325$ per 100lbs while production cost was \$3.70.MHS, Edwin F. Atkins Collection, Scrapbooks, undated newspaper clipping, c. fall 1901. fall 1901.

${ }^{27}$ MHS, Edwin F. Atkins Collection, Scrapbooks, undated newspaper clipping, c. 
politicians insist upon Cuba Libre.” Merchants in Havana protested when Young was relieved of his post because of his public comments. ${ }^{28}$

Sparse research on the annexationist movement within Cuba stands in direct contrast to the multitude of studies on supposed U.S. hegemonic designs of the island. In his classic revisionist analysis Philip Foner, traced Cuba's historical development over four centuries. He posited U.S. political and economic hegemony as the inevitable root of the Cuban Revolution and the instability in Cuba's nation-building. Traditional histories also have widely documented the struggles for independence in Cuba - a significant number as a result of the interest in 1898 and the U.S. intervention in the armed struggles between Cuba and Spain. ${ }^{29}$ More recently, historians such as Louis Pérez, Jr., have labeled U.S. intervention as unnecessary since patriots were about to win the war when the U.S. intervened. With more than a quarter of a million Cubans dead (about one eighth of the island's population including large numbers of civilians) as a result of the insurrection, Cuban elites wanted the intervention to avoid added social and economic instability which endangered their economic control. ${ }^{30}$ In a study that countered both Foner and

${ }^{28}$ MHS, Edwin F. Atkins Collection, Scrapbooks, newspaper clipping, 21 November 1901 and 12 December 1901.

${ }^{29}$ For an encompassing bibliography of U.S. historical literature on the war of 1898, see Anne Cipriano Venzon, The Spanish American War: An Annotated Bibliography (New York: Garland, 1990). For a fuller exposition of studies on 1898, see Louis A. Pérez, jr., The War of 1898: The United States and Cuba in History and Historiography (Chapel Hill: University of North Carolina Press, 1998), 159-268.

${ }^{30}$ Pérez, Cuba Between Empires, xvi-xviii, 215. U.S. interest in Cuba is reflected in coverage by the Quaker weekly The American Friend, 19 October 1899, which reported that the 1887 population of Cuba was 1.62 million and Army estimates in 1899 placed it at 1.2 million. RufusM. Jones, ed., "News and Events," The American Friend VI, no. 42 (19 October 1899): 1000. 
Pérez, John Offner argues for the inevitability of U.S. intervention for a "successful" outcome to the war in $1898 .{ }^{31}$ He notes that the war united the American people and provides insights into what issues they championed, adding that the perspective of each group was refracted through the prism of their experience. In another example, Gerald Poyo's study of the development of Cuban separatism among its émigré community argues for an ambivalent wavering among the expatriates between diplomatic solutions and direct confrontation. While the émigré communities served the separatist movement well in launching the armed conflict of 1895, he argues that subsequent waves of émigrés ultimately sought diplomatic solutions in the post-independence years. ${ }^{32}$ Adding to the instability, after 1898 Spain's economic control of sugar and tobacco interests on the island were purchased by the U.S. at fire sale prices and Cubans were largely shut out of the post war profits. In late October of 1901, Bartolomé Masó, who had supported collaboration with the United States during the War, declared openly against the Americans. He was quoted in Santiago newspapers stating the intervention had been "perverted into a military occupation approaching a conquest.” In vehemently opposing the Platt amendment, he appealed openly to the Afro-Cuban vote and asked for the support of his fellow veterans of the army to oppose U.S. rule. He also called on the

${ }^{31}$ John Offner, An Unwanted War: The Diplomacy of the United States and Spain over Cuba, 1895-1898 (Chapel Hill: University of North Carolina Press, 1992). See also Offner's earlier work, The Spanish-Cuban-American War and the Birth of American Imperialism, 1895-1902, 2 Vols., (New York: Monthly Review Press, 1972).

${ }^{32}$ Gerald Poyo, "Evolution of Cuban Separatist Thought in émigré Communities of the United States, 1848-1895," Hispanic American Historical Review 66, no. 3 (August 1986): 485-507. 
Spanish to unite with the Cubans as they were the "very nerves of [Cuba's] national life"33

\section{Raceless Cubanidad}

Unlike the effect on U.S. popular opinion, the war did not prove a catalyst for forging cubanidad; more than the U.S. or Spain, the "other” hindering cubanidad was other Cubans. Participation in an anti-colonial war also shaped individuals' perception of postwar opportunities and forced the realignment of social structures. Not surprisingly, historians of independence and the early republic have focused on the impact of issues of race and nation on cubanidad. The application of U.S. norms in the wake of intervention on the heels of Plessy v. Ferguson, facilitated appropriation of U.S. designations and paradigms for national and racial identity. The first three Cuban censuses—-the first two (1899 and 1907) conducted during U.S. occupation and supervision—adopted U.S. census' race categories of "white” and "colored” and further polarized social structures within Cuba as consensus continued to elude Cuban attempts at crafting a coherent nationalism. ${ }^{34}$

Despite the multiplicity of studies of race at the turn of the twentieth century, no easily discernable trajectory on issues of racial equality or political identity has emerged. Issues of race have traditionally been framed within the rubric of slavery or U.S. hegemony and

${ }^{33}$ MHS, Edwin F. Atkins Collection, Scrapbooks, undated newspaper clipping, c. October 1901.

${ }^{34}$ See U.S. Department of War, Report on the Census of Cuba, 1899 (Washington, D.C.: Government Printing Office, 1900). Subsequent censuses were conducted in 1907 and 1919. 
classic studies of slavery in Cuba proposed numerous paradigms for examining slavery and race-relations. ${ }^{35}$ Since the 1990s, however, there has been a proliferation of studies on race beyond the confines of slavery as "Neo-Martist” historians have argued for the betrayal of the national aspirations of Afro-Cubans. These studies may be classified along issues of revolutionary participation, political recourse, and race and racial politics in the formation of national identity. Alejandra Bronfman, for example, argues that the legal, political and scientific confusion of the early republic relegated Cubans of African descent to be defined as "deviant, unfit for citizenship, and thus occupying a very ambiguous position is the national scheme.” ${ }^{36}$ In the new Republic, Cubans of color were more closely scrutinized and excluded from civic participation even while nationalist discourse provided them with an ambivalent status as citizens as long as they exhibited "good behavior."

Cataloguing and analyzing the archival records of lesser known white and Afro-Cuban insurgents' daily lives during the wars of independence, Ada Ferrer argues that the early struggles for independence were doomed by racism because of the tensions of AfroCuban military leaders' rise to the command of white troops and the Spanish propaganda

${ }^{35}$ For two classic studies of slavery and emancipation in Cuba see Manuel Moreno Fraginals, El ingenio: Complejo económico-social del azúcar , 2 vols. (Havana: Editorial de Ciencias Sociales, 1978); and Rebecca Scott, Slave Emancipation in Cuba: The Transition to Free Labor, 1860-1899 (Pittsburgh: University of Pittsburgh Press, 2000).

${ }^{36}$ Alejandra Bronfman, "Unsettled and Nomadic: Law, Anthropology and Race in Twentieth-Century Cuba," University of Maryland, Latin American Studies Center, Working Paper No. 9 (2002), 42. 
that sought to divide insurgents along color lines. ${ }^{37}$ Martí’s rhetoric provided an opening for those of African ancestry to join with whites on the island in the revolt against colonial rule and served the philosophers' rhetoric that characterized the noble fight for independence as the struggle of equals for a "nation for all.” The 1899 census reported that "no hard and fast 'color line' has separated the colored and white Cuban population, although outside of the Cuban army, there has not been much of what may be called social intercourse ... no doubt the free association of colored and white Cubans resulted from the common struggle in which they were engaged against Spain, and the fact that the laws made no discrimination against them." ${ }^{\text {38 }}$ Ferrer argues, however, that the boundaries of citizenship and nationality continually shrank for Cuban Afro-Cubans and that the "ideology of a raceless nationality" eluded the insurrectionists. Constructed in part on the rhetoric of leaders of the previous two insurrections of the late-nineteenth century, "raceless" nationalist ideology proposed a Cuban nation predicated on racial equality. As the end of the war appeared close in 1898, however, Ferrer finds that white civilian and military leaders began to construct a scaffold for citizenship for an independent Cuba based on education, civility, refinement, and whiteness. It became clear that after independence the expectations of equality of Afro-Cuban veterans did not

\footnotetext{
${ }^{37}$ For discussions of the struggle of Cubans of African descent to assert their rights of citizenship in the emerging Cuban nation, see Ada Ferrer, Insurgent Cuba: Race Nation and Revolution, 1868-1898 (Chapel Hill: University of North Carolina Press, 1999); Alejandro de la Fuente, A Nation for All: Race, Inequality, and Politics in Twentieth Century Cuba (Chapel Hill: University of North Carolina Press 2001); and Alejandra Bronfman, Measures of Equality: Social Science, Citizenship, and Race in Cuba, 1902-1940 (Chapel Hill: University of North Carolina Press, 2004).

${ }^{38}$ United States Department of War, Report of the Census of Cuba, 1899 (Washington, D.C.: Government Printing Office, 1900), 69.
} 
translate into political power, economic advantage, or social equality and were largely decimated within a decade.

Pre-dating Ferrer's work, Aline Helg's analysis of the formation of the Partido Independiente de Color (PIC), and within four years the massacre of its members, follows Ferrer's work chronologically. Noting that “race still dominated many aspects of political and socioeconomic relations in Cuba,” Helg provides a detailed study of Cuban race relations from 1816-1912 by examining the continuing socio-economic marginalization of Afro-Cubans after independence. ${ }^{39}$ According to Helg, the discrepancy in the nationalist rhetoric of a nation free of racial discrimination and equal opportunity was soon crushed by the economic marginalization, and the social and racial discrimination of its citizens of color. Established in 1908, the PIC’s platform included free education for all, judicial and penitentiary reforms, and in the aftermath Cuba's avid promotion of "white" immigration, the priority of employment and distribution of lands for Cubans. By 1909, Helg argues, with universal male suffrage, the PIC "threatened the franchise of the white power structure and electoral success [in the 1910 election] would have changed the racial makeup of the national congress." 40 She notes that mass arrests and imprisonment prevented the party’s participation in the elections and that disillusionment was widespread among Afro-Cuban citizens of the republic. Nancy

${ }^{39}$ Aline Helg, Our Rightful Share: The Afro-Cuban Struggle for Equality, 18861912 (Chapel Hill: University of North Carolina Press, 1995), 3. For discussions of the development of Afro-Cuban political thought see also, Rafael Fermoselle, Politica y Color en Cuba: La Guerrita de 1912 (Montevideo: Ediciones Géminis, 1974) and The Evolution of the Cuban Military: 1492-1986 (Miami, Ediciones Universal, 1987).

${ }^{40}$ Helg, Our Rightful Share, 5-6. 
Raquel Mirabal found in her study of Afro-Cubans in Ybor City, that despite Martís efforts to define Cuba as a nation for all, "the Cuban community remained essentially divided and stratified. Revolutionary and cultural clubs formed on the basis of race, ethnicity, gender, and class.” Similarly to the island, so Cubans abroad founded clubs like La Unión Martí-Maceo, the Obreras de La Independencia and El Círculo Cubano based on Martían principles of freedom and equality. Not one of the clubs, however, was racially integrated. ${ }^{41}$

Other studies of race and Cuban national identity have provided a broader foundation for the debate for national ambivalence. In A Nation for All: Race, Inequality, and Politics in Twentieth Century Cuba, Alejandro de la Fuente examines the issue of race in competing visions of nation building and Cuba's electoral politics from 1902 through the 1950s. He argues that for Afro-Cubans political organizing increased racism and kept Cubans from forming the "nation for all" noting that the labor market and access to education were key areas where inequality flourished. By the 1950s, de la Fuente posits that Cuba was a completely segregated society in almost every area including sports, education, entertainment and especially the labor sectors. For Cuba, the unresolved tension between racism and anti-racism in national consciousness created an atmosphere of ambivalence in racial matters that spilled over to other socio-cultural sectors. ${ }^{42}$ Robin Moore’s study

${ }^{41}$ In Tampa, “La Unión Martí- Maceo” was a male Afro-Cuban club, La Obrera de la Independencia included only white Cuban women, and white Cuban males comprised the membership of El Circulo Cubano. Nancy Raquel Mirabal, "The AfroCuban Community in Ybor City and Tampa, 1886-1910," OAH Magazine of History (Summer 1993): 19-22.

${ }^{42}$ Alejandro de la Fuente, A Nation for All: Race, Inequality, and Politics in Twentieth Century Cuba (Chapel Hill: University of North Carolina Press 2001). 
of the acceptance of Afro-Cuban rhythms in Cuban popular music, which focused on the decades from 1920 through 1940, further examines the ambivalence of nationhood as expressed in musical composition of the period. She argues that the nation continued to straddle the ambivalence of finding common ground between acknowledging the uniquely African contributions to the development of the nation and the prevailing orthodoxy of race that posited anything African with backwardness and moral degeneration. ${ }^{43}$

In a microhistorical look at racism in Cuba, Reyita: The Life of a Black Woman in the Twentieth Century, Maria de las Reyes chronicles the multiple strategies used by women of color to provide for their families. ${ }^{44}$ The story of a mixed blood Cuban woman, poor and with limited education, as told by an elderly Reyita, details the shame her family felt because she looked "black" while her three sisters did not. Reyita decided to marry a white man hoping to gain respect and standing in society -ultimately, however, it did not matter. She was consistently excluded from opportunities for upward mobility and social acceptability because of her "color” and "appearance.”

Macrohistorical issues of power, politics, and race, built on a foundation of economic disparity, reinforced the division and ambivalence in Cuban national ideology—a

${ }^{43}$ Robin Moore, Nationalizing Blackness: Afrocubanismo and Artistic Revolution in Havana, 1920-1940 (Pittsburgh, PA: University of Pittsburgh Press, 1997). For an important analysis of the dynamics of Afro-Cuban ideology and the ambivalence of its outworking in Cuba during the first four decades of the Republic see Alejandra Bronfman, Measures of Equality (Chapel Hill: University of North Carolina Press, 2004).

${ }^{44}$ Maria de la Reyes Castillo Bueno, Reyita: The Life of a Black Cuban Woman in the Twentieth Century, translated by Anne McLean (Durham: Duke University Press, 2000). 
division that appeared to contemporary observers as insurmountable. Within a few short months after the election of its first President, in May 1902, La Lucha reported that it was impossible to speak of a united Cuban nation, arguing that the divisions along lines of class and race were just too great. The promise of a new beginning on Cuban terms had failed to materialize. In its first decade, beleaguered by racism and finding little common interpretations of Liberte, the "nation for all” was plagued by a failed experiment in autonomy, post-war foreign occupation, lack of ideological or political coherence, a disgruntled Afro-Cuban population that marked its influence in sheer numbers, and a deteriorating economy with sugar production shut down, unemployment, destitution, vagrancy, and unfettered smuggling. ${ }^{45}$ It is during inflection points such as Cuba faced in the years after independence- economic disappointment, political and social ambivalence, and failed attempts at defining cubanidad — that spaces for the formation of national myths were created.

\section{Public Dreams}

Such myths have been called "public dreams.” They are seen as mechanisms that provide a society with the means to cope with dramatic and disappointing change. In her analysis of two millennia of classical mythology and identity, Karen Armstrong noted that mythmaking allows a society to experience reality through an ideal, providing “explicit shape and form to a reality people sensed intuitively." ${ }^{46}$ In particular, she

${ }^{45}$ MHS, Edwin F. Atkins Collection, Scrapbooks, undated newspaper clipping, c. June 1901.

${ }^{46}$ Karen Armstrong, A Short History of Myth (New York: Canongate, 2005), 148. 
argues that the "myth of the hero was not intended to provide us with icons to admire, but was designed to tap into the vein of heroism within ourselves. ${ }^{47}$ At the birth of the new republic Alberto Yarini y Ponce de León was perceived as one such hero, the incarnation of Cuba's public dreams in a single man. Examining the mythology of Cubanidad built around the person of Alberto Yarini in subsequent decades may provide clues as to the nature of leadership and of Cuba’s evolving natural identity; how a quasi-democratic elite, admired by "the mob," rose to power in a corrupt system and for many became a symbol of what it meant to be Cuban.

The implications of a foundational national myth argue for the creation of a system that is born of each individual's perception of his or her own reality. For Cubans, with no political ideology or cultural tethers that turned national aspirations into tactile realities, several factors combined in the creation of that myth. First, a political ambivalence existed that sharply divided the proponents of self-rule and that aligned political parties along lines of racial interests and "personalism" rather than on guiding principles. Second, a social ambivalence resulted in the aftermath of a war with a displaced and financially struggling planter class, Spaniards who remained in residence and retained Spanish citizenship—it was regarded as newsworthy when the Marques de Montoro resigned his title and became a Cuban citizen—and a merchant class that could not succeed in its aspirations. ${ }^{48}$ Third, a well-defined "other," in which the U.S. had clearly

${ }^{47}$ Ibid., 135.

${ }^{48}$ MHS, Edwin F. Atkins Collection, Scrapbooks, undated newspaper clipping, c. June 1902. The Marques was to represent the Cuban planter interests in the metropolis. In "The Collapse of the Cuban Planter Class,” Louis A. Pérez argues that Cuban independence was the last of series of events that effectively toppled the planter class. In 
replaced Spain as the focus, became a reality in Cuba at the turn of the twentieth-century. Fourth, the lengthy time period of nationalist ambivalence that followed independence provided the opportunity for a heroic myth to materialize. Last, every myth must have its hero or heroine; and young heroes, especially those martyred young, are much more effective. For Cuba, a young, defiant and charismatic hero fulfilled the need for the emergence of a "champion for all."

In the sharply debated interpretation of Latin American values, The Public Man, Glen Caudill Dealey argues that "the spirit of caudillaje" was an immutable cultural feature of the Latin American ethos. Contrasting the northern European "Protestant ethos" with “Catholic values,” Dealey argues that for Latin Americans the caudillaje life-style "embraces a concept of man personified as a leader in a public setting ... not as political leader, but as a style of life according to which everyman attempts to be a leader., ${ }^{29}$ In the "caudillo as hero" culture, the true leader measures his (almost exclusively male) virtue in terms of accumulated public power, "he thinks, acts, and has his being within a framework of public values." ${ }^{50}$ With long roots tracing back to Greco-Roman culture, the public man then is the "surrounded man" who lives out his life in a public forum where the numbers of admirers, clientes (hangers-on; clients) and seguidores (followers)

its place emerged a bourgeoisie that looked to U.S. largess to guarantee national political and economic stability and thus promoted U.S. hegemony; Pérez, "The Collapse of the Cuban Planter Class,” 3-22.

${ }^{49}$ Glen Caudill Dealey, The Public Man: An Interpretation of Latin American and Other Countries (Amherst: University of Massachusetts Press, 1977); see also Glen Caudill Dealy, The Latin Americans: Spirit and Ethos (Boulder, CO: Westview Press, 1992).

${ }^{50}$ Dealey, The Public Man, 44. 
he collects around him become the measure of his power and influence; he collects seguidores by liturgical acts that make the people indebted to the person and not the state. ${ }^{51}$ According to Dealey, the amassing of "friends" and the expansion of this network become the ultimate purpose of life for the public man and in the quest for public influence, the lines between private and public morality become blurred. In many ways, Alberto Yarini represented the ultimate Cuban "public man.”

For historians, "life stories provide authenticity and intimate portrayals of the past. They also verify or nuance important historical events or trends. ${ }^{\text {} 52}$ Microhistorical studies generally focus on outliers; on individuals who often run counter to the established norms of their societies. These individuals provide a lens through which to study "those who in one segment of society are considered obscure, strange, and even dangerous [and who] are, in other circles, at the center of attention and fully accepted in their daily affairs." 53

${ }^{51}$ Literally "to do for the people," the term liturgy (leitourgia) is from the Greek and originally was used to describe a public duty or service performed by the wealthier citizens at their own expense, especially in providing public works. The citizen would often be named to a public honor or title (e.g. the gymnasiarch, who supported the gymnasium or the choregus, who paid the singers of a chorus in the theatre). For the wealthy, the leitourgia became mandatory and very expensive (especially in the Roman Republic), securing the patron's standing among elites. It became used of general service of a public kind and was later appropriated for the performance of public religious service. See Naphtali Lewis, "Leitourgia and Related Terms," Greek, Roman and Byzantine Studies 3 (1960):175-84; and "Leitourgia and related terms,(II)," 6 Greek, Roman and Byzantine Studies (1965):226-30; John Westerdale Bowker, Oxford Dictionary of World Religions (Oxford: Oxford University Press, 1997) 582-83.; and Svatoslav Dmitriev, City Government in Hellenistic and Roman Asia Minor (New York: Oxford University Press, 2005), 17-18.

${ }^{52}$ K. Lynn Stoner, book review, Reyita: The Life of a Black Cuban Women in the Twentieth Century, The Americas 58, no.2, (April 2002): 653-655.

${ }^{53}$ Sigurdur Gylfi Magnússon, "The Singularization of History: Social History and Microhistory within the Postmodern State of Knowledge," Journal of Social History 36, 
The story of Alberto Yarini illustrates the power and influence of the public man to provide moments of solidarity amidst the chaos of Cuba's nation-building efforts. Cubans had aspirations of nationhood but lacked the power to coalesce and realize their aspirations. Amid ideological chaos, how could individuals contribute to Cuba's everemerging nationhood? By forming relationships like Yarini's that transcended class, race, gender, and politics. His story serves to illustrate the complicated interactions between individual experience and national events. ${ }^{54}$ Yarini's story and subsequent myth were resurrected throughout twentieth-century Cuban history and again in the new millennium, allowing those who felt powerless to appropriate power and alleviate a frustrated nationhood. This is the account of one person who embodied the nation's dreams and took on a reality larger than life.

The works of Tomás Fernández Robaina and Dulcida Cañizares, both of which rely on interviews of Yarini contemporaries, relatives, and on local lore, were important sources for this study. ${ }^{55}$ Through interviews, Robaina's work focuses on the prostitutes Yarini

no. 3 (Spring, 2003):701-35. On microhistory see, Rebecca J. Scott, "Small-Scale Dynamics of Large-Scale Processes," American Historical Review,105, no. 2 (2000): 472-79; Georg G. Iggers, Historiography in the Twentieth Century: From Scientific Objectivity to the Postmodern Challenge (Hanover, NH: Wesleyan University Press, 1997). See also Carlo Ginzburg, The Cheese and the Worms: the Cosmos of a SixteenthCentury Miller, trans. John and Anne Tedeschi (Baltimore, MD: Johns Hopkins University Press, 1980); and Giovanni Levi, “On Microhistory,” in Peter Burke, ed., New Perspectives on Historical Writing (Cambridge: Polity Press, 1991).

${ }^{54}$ Karen Armstrong, "Ambiguity and remembrance: individual and collective memory in Finland,” American Ethnologist 27, no.3 (2000): 591-608.

${ }^{55}$ Tomás Fernández Robaina, Historias de Mujeres Públicas (Havana: Editorial Letras Cubanas, 1998) and Dulcila Cañizares, San Isidro, 1910: Alberto Yarini y su epoca (Havana: Editorial Letras Cubanas, 2000). See also Dick Cluster and Rafael 
managed in San Isidro and provides their idealized perceptions of their protector. Cañizares’ work emphasizes Yarini’s family history and his imposing personality in Havana. My work adds to these two foundational studies by focusing on the transcending nature of the story of Yarini by examining archival records, court proceedings, memoirs, and newspaper accounts,. If Martí was the literate philosopher of freedom and the martyr to liberty, then Yarini was the masculine defender of the powerless and martyr of the helpless and marginalized. Working in the barrio among the lowest rungs of society, blocks away from the house where Martí was born, for many Cubans Yarini embodied Martí's aspirations for a "nation for all” and carried them out in the microcosm of his world. This was the only one who could truly speak up for Cuba and cubanidad: a well-to-do white man of the respectable class who embraced the struggles of the disenfranchised. As an elite-born, well-educated and socially-connected Cuban, Yarini had the standing needed to represent "his" people. His membership in the Abakuá secret society, a position generally limited to working class Afro-Cubans, guaranteed his standing among the displaced. A single act of solidarity and resistance against the U.S. embodied Cuban aspirations of strength, sovereignty and nationalism. These all interacted in the Cuban world view of class, race, and machismo.

\section{Conclusion}

Perhaps Cubans tapped into Yarini as a real life hero who emerged at a time of ideological uncertainly and “conquest,” during a period of great promise that ultimately

Hernandez, The History of Havana (New York: Palgrave and Macmillan, 2006), 123134. 
resulted in a failed nationalism and broken dreams. But why appropriate a Yarini versus a Jose Martí or Antonio Maceo? At a time when government was weak and nationalistic ideology fragmented at best, Yarini could navigate the disparate worlds of ambivalent cubanidad; he was appropriated by the popular classes because he chose to live and be identified with them. He was what they wanted to be: action-oriented, in control, brave, and —unlike what Martí or Maceo had been able to accomplish—able to provide patronage.

He was seen as a man of honor who spoke with his actions more than with his words. Yarini was not a woman, a black man or poor but through his actions he spoke to women, blacks, and the poor. Had he been black, his defiance of the U.S. probably would not have been perceived as a nationalist act but as racially reactionary. Had he been a woman he would have been little more than a chusma (lacking class; lowlife). Had he been poor, he would have little to lose and his actions would have been dismissed. One way in which overlooked groups can express themselves is through Yarini types who have no qualms joining Afro-Cuban groups or interacting with women. They will listen to Yarini and allow him to speak and act for them as a different kind of efficacious hero whose political acumen and promise made him a powerful force in official circles. Interestingly, Yarini could do what he did only because he was of the hegemonic class and race - his only transgression was directed against American power and viewed as 
justified and patriotic transgression by Cubans. When he died, assassinated by a rival French souteneur's bullet, Yarini was eulogized as a man of honor and a patriot. ${ }^{56}$

Yarini's memory and actions were resurrected at watershed moments in Cuban history and in the twenty-first century have once again risen to embody a populist Cuban ideal. ${ }^{57}$ In the aftermath of a failed republic, with the ouster of President-turned-dictator Gerardo Machado in 1934 and through the uncertainty of the 1950s there arose the need for a cultural symbol of defiance and Yarini was once again called up in the public memory as the valiant protector. In 1959, Fidel Castro transformed the face of Cuban history when his rag-tag army of revolutionaries assumed control of the island. That same year, Cuba’s foremost playwright, Carlos Felipe published his most famous play, Réquiem por Yarini. In the style of a Greek tragedy, the play chronicles the death of “Alejandro" Yarini, part man, part demi-god, and the supernatural forces that placed control of his destiny in the hands of the gods The play codified the legend of Alberto Yarini y Ponce de León, a criollo, habanero, and champion of cubanidad, who left his mark on the country during the first decade of the Cuban republic and was transformed into what has been described as Cuba's first national myth. ${ }^{58}$ Yarini was the perfectly

${ }^{56}$ Souteneur is from the French, literally "protector," from soutenir "to sustain"; its first recorded use was in 1906. The term came to mean a man who lives on the earnings of one or more prostitutes under his protection. Oxford English Dictionary (Oxford: Oxford University Press, 2008).

${ }^{57}$ Recent Cuban microhistorical studies are the topic of a collection of nineteen articles in Fernando Martinez Heredia, Rebecca J. Scott, and Orlando F. Garcia Martinez, ed., Espacios silencios y los sentidos de la libertad: Cuba entre 1878 y 1912 (Colección Clio. Havana, Cuba: Ediciones Unión, Unión de Escritores y Artistas de Cuba, 2001).

${ }^{58}$ Carlos Felipe, Réquiem por Yarini: Drama trágico en tres actos (Miami: Ediciones Calesa, 1978). 
crafted character for the play of Cuban nationalism. In the new millennium, at the centennial of his death, Yarini has gained more popularity as a national anti-hero than ever before. Over the last decade, “The man who would be President” has become a revitalized cultural icon and the account of his life has been the subject of countless popular articles, a novel, and two new movies. ${ }^{59}$ His story has been described as the foundation for Cuba's first national myth; a process that has taken a century to unfold.

“A man does not make a nation,” José Martí wrote, "but the nation at times may find its vibrant triumphant incarnation in a Man." ${ }^{60}$ This study looks at the broader transformations in Cuban history through the case study of a single, yet symbolic, man, and proposes a new paradigm for understanding the dynamics of Cuban society and culture. It also examines the implications for Cuba's aspiring national identity at the turn of the twentieth century, not in the iconography of war heroes such as Antonio Maceo or the hagiography of independence philosophers such as Jose Martí, but by detailing the interplay between fact and fiction in the story of Alberto Yarini: elite born; welleducated; politically and socially well-connected; powerful; and celebrated racketeer and chulo. He was "vibrant and triumphant" at a time when other nation-building forces in Cuba were weak and ambivalent. A century after his dramatic death, Yarini fully became the quintessential "public man" who symbolized a cubanidad not defined in terms of the ideological hegemony of class, race, or gender, but who through his actions dispelled the ambivalence of Cuban nationalism. He continues to engage the collective consciousness

59 “El chulo que soño ser presidente,” Bohemia, December 2001, 54.

${ }^{60}$ Quoted in Alistair Hennessy, “The Roots of Cuban Nationalism,” Journal of International Affairs 39, no. 3 (Jul., 1963): 345-59. 
of Cubans both on and off the island to bridge the gap "between the way [Cubans] live and what [they] want.” 61

${ }^{61}$ Leviston, "Scandinavia," 76. 


\section{CHAPTER II}

\section{“LA IMPENETRABLE ÉGIDA DE MI PERSONA”':} FROM TUSCANY TO HAVANA

Bachiller José Leopoldo Yarini Klupfel, master of the Ingenio de Nuestra Señora del Rosario in Matanzas wrote in his eye-witness account of the cholera epidemic that swept through Matanzas during 1831-33 that his slaves “firmly believed they would be protected [from the onslaught of cholera] by the impenetrable shield of [his] person and that while [he] was with them they had nothing to fear."2 The owner and guardian of the slaves of the Ingenio del Rosario had made his fortune in Cuba at a time when the island was emerging anew as Spain's colonial jewel. With the sugar revolution of the nineteenth century, Cuba transformed itself from a neglected imperial way-station to Spain's most valuable source of income. ${ }^{3}$ Partly through accidents of fortune and partly

\footnotetext{
${ }^{1}$ José Yarini Klupfel, “Relación de Cólera, 1833,” Archivo Museo Nacional de Historia de las Ciencias, Havana, Cuba; document copy courtesy Miguel Angel Sabater.

2 “Todos ellos creían firmemente estar defendidos con la impenetrable égida de mi persona, y que estando yo con ellos no tenían por que temer,” José Leopoldo Yarini Klupfell, "Relación de Cólera, 1833”. In 1995, members of the staff of the Museo Nacional found a misplaced document labeled "Cólera 1833" which was the account of José Leopoldo Yarini's experience during cholera epidemic of 1833. The document was made accessible and subsequently transcribed, translated, and digitized and is available online; "Colera en el ingenio," http://www.thefullwiki.org/wiki//C\%C3\%B3lera_en_el_Ingenio (acessed 25 June 2009).

${ }^{3}$ Franklin W. Knight, "Origins of Wealth and the Sugar Revolution in Cuba," Hispanic American Historical Review 57, no. 2 (May, 1977): 231-253. See also Cesar Ayala, American Sugar Kingdom: The Plantation Economy of the Spanish Caribbean, 1898-1934 (Chapel Hill: University of North Carolina Press, 1999); Alan Dye, Cuban
} 
by design, José Leopoldo certainly capitalized on this opportunity and in doing so

became the founder of a well-respected Cuban family that would leave a significant impact on a new nation. ${ }^{4}$

\section{Il Regno d'Italia}

José Leopoldo Yarini was born to a relatively well-off family in 1775 in Florence, in the

Kingdom of Etruria (modern day Italy), which was at the time ruled by the Austrian

Sugar in the Age of Mass Production: Technology and the Economics of the Sugar Central, 1899-1929 (Stanford: Stanford University Press, 1998); and Oscar Zanetti and Alejandro Garcia, trans. By Franklin Knight and Mary Todd, Sugar and Railroads: A Cuban History, 1837-1959 (Chapel Hill: University of North Carolina Press, 1998).

${ }^{4}$ Much has been written in the popular press about the ancestry of Alberto Yarini with many discrepancies, inaccuracies, and figments of the imagination. The story of José Leopoldo Yarini Klupfel's (JLYK) voyage to Cuba is described in his application to the University of Havana for admission and completion of a medical degree, dated 1809. Archivos de la Universidad de la Habana (hereafter AUH), Expediente administrativo, José Yarini Klupfel, 14, No. 961 (1809). Affidavits attached to the application include the following: (1) in a document dated 6 August 1809 Simón Bergaño y Villegas, Master of Arts and oficial mayor de la Secretaría de Cámara del Gobierno y Capitanía, Ceiba de Agua, testified to having seen the documents proving JLYK completed studies in philosophy during 1802-1803. It also notes the arrival of JLYK in Omoa in December 1805 when Captain José Rafael Parrigo reviewed his documents and sent a report to the capitanía general. (2) Antonio José de Morejón Sotolongo, Capitán del partido San Luis de la Ceiba, dated 11 August 1809, testifies having seen documents noting that JLYK completed his studies in Philosophy and practical physics at the Real Universidad de Latinidad of Florence in 1801; he also provides corroboration of the fire in the home of Don Tomás Ramos in 1809. (3) Pedro Alcántara Dueñas, vicar of the church of San Luis de la Ceiba, dated 15 May 1809, certified as to the loss of JLYK documents in the fire and of his "laudible conduct" during his three-years stay in the parish. He also notes that in 1809 Yarini practiced at the San Ambrosio military hospital and had completed his studies in Latin and Philosophy with practical Physics in Florence and practiced anatomy and medicine at the Liorna city hospital. (4) Joaquín Muñoz, surgeon at the San Ambrosio hospital testified that JLYK studied surgery under his direction from 1808 through December 1810 with great profit (aprovechamiento). (5) Nicolas Vicente del Valle, testified that JLYK studied medicine at University of Havana from Sept 1809 to Dec 1810 with outstanding grades. 
Dukes of Lorraine. ${ }^{5}$ He was baptized in St. John’s Parish in Siena; although his parents were probably of foreign descent: José Yarini of Turkish or Hellenistic ancestry and Maria Theresa Klupfel, reportedly the daughter of an Austrian military officer. ${ }^{6}$

Under Austrian control, Tuscany provided a stable and comfortable life for José Leopoldo. He completed his early education and began secondary studies while the family lived in Siena, where his father served as prosecutor for the Florence City Council. $^{7}$ The Napoleonic Wars, however, created uncertainty in the kingdoms of the Italian peninsula and during the decade beginning in 1799, Napoleon's armies methodically seized control of the Italian peninsula in stages, annexing its territories to

${ }^{5}$ There is a discrepancy as to the date of birth of José Leopoldo Yarini Klupfel. José Leopoldo’s birth date is listed as 1785 (LDS Family Search International Genealogical Index, v. 5.0, lists; IGI, Batch Number 8768202, Sheet 06, Source No. 1396373. José Leopoldo's application to the University of Havana in 1809 lists him as being 30 years of age at the time, placing his date of birth as 1779; AUH, Expediente administrativo José Yarini Klupfel, 14, No. 961 (1809). The Matanzas parochial burial register records José Yarini's burial “at age 50” in 1839. Archivo de la Catedral de Matanzas (hereafter ACM), Entierros de blancos, Libro 9, Folio 194v, No. 1335. If this record is accurate, it would place patriarch's date of birth as 1789 , and probably too young to have completed his medical career and traversed the Atlantic to Cuba by 1805 . (Note: there are a large number of inconsistencies in the LDS records.)

${ }^{6}$ José Yarini and Maria Therese Klupfel were married in Florence in 1782. The Yarini name is most likely a Latinization of the Hellenic Ianis (Yanis) and is found only in Cuba and subsequently in the United States. "José Yarini b. 1760 Firenze, d. 1832" is the first "Yarini" entry in the IGI International Index. Maria Klupfel is listed as having been born in 1763, in Florence, but no date of death is available; LDS IGI, Index, v5.0, Batch Number 8768202, Sheet 06, Source No. 1396373. In the United States, the Yarini name first appears in the 1920 census with an entry for Ralph (b. 1895) and Mary Yarini (b.1904) residing in Carbon, Utah; Fourteenth Census of the United States Taken in the Year 1920, Population 1920 (Washington D.C.: Government Printing Office as cited in results for "Yarini Family Search," ancestry.com (accessed 14 August 2010).

${ }^{7}$ AUH, Expediente administrativo José Yarini Klupfel, 14, No.961. 
the French empire. Austrian control of Tuscany ended in 1801 and with French permission, the Spanish ruled for a few short years.

In 1800, Napoleon signed a secret treaty with Spain under the terms of which Spain ceded Louisiana to France in return for the Kingdom of Etruria which was made a Spanish kingdom for the daughter of Charles IV, Maria Luisa. ${ }^{8}$ The ill-fated Treaty of San Ildefonso (formally announced in 1801) was short lived and ultimately granted the Spanish Crown control of Etruria for only six years. It was during that short interlude that José Leopoldo seized the opportunity afforded by the Spanish regency to flee French control. In 1803, as the instability of the political situation escalated and Franco-Spanish relations deteriorated after the sale of Louisiana to the United States, the Yarini family left their comfortable life in Siena for the coastal town of Livorno where José Leopoldo continued his studies in anatomy and medicine for approximately one year. ${ }^{9}$ Apparently the young student was unable to complete his studies because of the French expansion and occupation, political turmoil, and the family's forced flight.

${ }^{8}$ In 1737 Medici rule came to an end in Tuscany and the Austrian Dukes of Lorraine ruled the region. In 1801, Napoleon signed the Treaty of San Ildefonso with Spain which ceded Tuscany to Spain in exchange for the territory of Louisiana. Two years later (1803), France sold Louisiana to the United States reneging on the promises made to Spain in the treaty. In 1807 Napoleon dismissed the Spanish regent in Etruria and declared his sister queen, effectively ending Spanish rule in Italy.

${ }^{9}$ The Treaty of Ildefonso was ill-received in Spain; see "Sobre la Sesion de las Floridas: Carta de un español a un amigo suyo,” El censor: Periódico político y literario [Madrid] 2 (1820): 380-381: "Dícese que de resultas de un tratado ventajoso que hizo nuestro ministerio allá en San Ildefonso en el año de 1800, tuvimos la gran fortuna de cambiar la provincia de la Luisiana nada menos que por el reyno de Etruria, sin otra adeala que dar seis navíos de línea par dessus le marché. Creyose entonces que los tales navíos iban allá para traerse embarcado el susodicho reyno; pero no sucedió así, porque desde entonces no hemos vuelto a ver ni reyno, ni navíos, ni Luisiana, ni Cristo que la fundó." 
José Leopoldo found a new possibility for advancement. Seizing the opportunity of the Bourbon-Parma regency, sometime in 1804 the young José Leopoldo left Livorno for Barcelona and after a short time in the city, obtained authorization to travel to the Americas. ${ }^{10}$ He booked passage for Veracruz in New Spain, carrying letters of recommendation and certification of the extent of his studies in medicine.

\section{Hacer la América ${ }^{11}$}

During the month-long sea crossing, a storm forced a change in the ship's course and in December 1805 the vessel carrying José Leopoldo was forced to seek safe harbor in the port of Omoa in modern-day Honduras. ${ }^{12}$ The passengers spent some time in the port while the ship made repairs. Short of funds, José Leopoldo was unable to find work there even when venturing out to the surrounding villages. Somewhat discouraged and with little prospect of making a living, he once again set out to sea, although his final destination is not quite clear. He was probably still bound for Veracruz, this time via Havana, trying to complete his voyage.

Within a few days, however, the Italian arrived in Surgidero de Batabanó gravely ill. Batabanó was a small port on the south coast of Cuba which Alexander von Humboldt,

${ }^{10}$ Jose Leopoldo's affidavits for admission to the University of Havana include information that the governor of Barcelona was the Count of Santa Clara, Juan Procopio de Bassecourt y Bryas. He served as Captain General of Cuba for three years (6 December 1796 - 13 May 1799) and had returned to Spain and served as Captain General of Cataluña (14 May 1802 - 1808), the time of Yarini’s departure from Barcelona.

11 Ángel Bahamonde Magro and José Cayuela Fernández, Hacer las Américas: Las elites coloniales españolas en el siglo XIX (Madrid: Alianza Editorial, 1991).

${ }^{12}$ AUH, Expediente administrativo José Yarini Klupfel, 14, No. 961, Folio 9. 
the German naturalist who traveled throughout the Caribbean in the late 1790s, described as a tree-less marsh infested region teeming with pointed snout caymans and cocodrilos and which served as a haven for "merchants" (smugglers). Its proximity to Havana (about 25 miles) made the port important both for commerce and as a military outpost. ${ }^{13}$ With a small population of just over 1000, Batabanó and its surroundings nevertheless boasted several sugar and coffee estates. ${ }^{14}$ The experience in the region may have served José Leopoldo well in his later business dealings.

Forced to leave the ship and once again interrupt his voyage, this time because of his illness, José Leopoldo was cared for at the Villa de Santiago in Batabanó until locals suggested he move inland away from the swampy coast (perhaps because he suffered from yellow fever). Although he probably had expected to take the Camino Real from Veracruz inland to Mexico City as the end of his voyage, instead he convalesced in the small rural way-station of Ceiba del Agua outside of Havana at the home of Tomás Ramos. José Leopoldo, who seemed to always make the best of every situation, subsequently lived in the Ramos home for about three years, picking up some meager funds by teaching the villa's children and neighbors. ${ }^{15}$ Noting his "bad luck and his desire to pursue his studies, especially in medicine,” José Leopoldo also took a job as a

${ }^{13}$ Alexander von Humboldt, The Island of Cuba: A Political Essay (Princeton: Marcus Wiener Publishers, 2001), 127, 360, 364.

${ }^{14}$ In 1818 the population of Batabanó was just over 2000, with 13 sugar and 7 coffee estates. Humboldt, The Island of Cuba, 358.

${ }^{15}$ AUH, Expediente administrativo José Yarini Klupfel, 14, No. 961, Folio 10. 
surgeon's assistant at the Hospital Real Militar de San Ambrosio, in Havana from 18081810 under the direction of Joaquin Muñoz.

It was during his time as a surgeon’s apprentice that an "unexpected situation” arose in Havana during March of 1809, probably precipitated by Spain’s declaration of war against France in July 1808 and the subsequent expulsion of all "French nationals" from Cuba by order of the Captain General Marques de Someruelos. ${ }^{16}$ After riots broke out between French settlers and Cubans in Havana, José Leopoldo saw an opportunity to act on his animosity of the French and quickly joined the city's local militia (Juntas de Vigilancia) ${ }^{17}$ More than 30,000 French residents had fled Saint Domingue after the slave rebellion of 1791 and eventually settled across Cuba, buying up property and thus perceived as limiting economic opportunities for other immigrants; in his militia role José Leopoldo could take great pleasure in participating in the expulsion of the French from Cuba. $^{18}$

Now a member of the Juntas, José Leopoldo continued to advance his medical aspirations serving as an apprentice in Havana's military hospital, one of two in the city. The charity

${ }^{16}$ The order was issued on 12 March 1809 and was a reiteration of an order issued two years earlier that proved unenforceable. French nationals who had not sworn an oath of allegiance to Spain or married Spanish citizens were forced to leave Cuba - many emigrating to New Orleans. Ned Sublette, The World that Made New Orleans: From Spanish Silver to Congo Square (Chicago: Chicago Review Press, 2008), 250. For a description of the riots and the importance of the military see Johnson, The Social Transformation of Eighteenth-century Cuba, 175.

${ }^{17}$ AUH, Expediente administrativo, José Yarini Klupfel, 14, No. 961 (1809).

${ }^{18}$ Richard Gott, Cuba: A New History (Yale University Press: 2005), 45-48; and Johnson, The Social Transformation of Eighteenth-century Cuba, 176-77. 
hospital (public) San Felipe y Santiago administered by the friars of San Juan de Dios and the military hospital of San Ambrosio provided varying levels of treatment and convalescence for Havana residents. In 1814, it was reported that the annual mortality rate for San Felipe was more than 24\%, while that same year San Ambrosio boasted a mere $4 \%$ in annual patient deaths. Although more patients were admitted to San Ambrosio (about 3.5:1), the difference in mortality rates was attributed not to the quality of care, but to the severity of the cases admitted to each. In San Ambrosio, the cases were generally minor disorders which could be readily treated. Operating more like a hospice for indigents, the Friars of San Felipe admitted all cases including the aged, the incurable, and slaves, who, according to Humboldt, often were deposited there by their owners to rid themselves of their care. ${ }^{19}$ Working in the relatively salubrious and elite military hospital, José Leopoldo learned his trade well and his services were recognized and rewarded by his superiors so that after three years' work, he received a commendation of merit as practicante meritoso. ${ }^{20}$

While working at San Ambrosio, on 2 May 1809 a fire at the home of his benefactor, Don Tomás Ramos, in Ceiba del Agua reportedly destroyed all of José Leopoldo’s personal travel documents, education credentials, and apparently all his clothes, because he later noted he was unable to attend daily mass the morning following the fire as he had

${ }^{19}$ Figures for 1814 for the military hospital of San Ambrosio record that there were 4352 patients admitted that year with 164 recorded deaths. The same year, San Felipe admitted 1484 and recorded 283 deaths. Humboldt, The Island of Cuba, 115-16.

${ }^{20}$ AUH, Expediente administrativo, José Yarini Klupfel, 14 No. 961, Folio 11. 
nothing to wear. ${ }^{21}$ Perhaps prompted by his continued misfortunes and lack of funds, in October 1809, the then 30-year-old Italian applied to the University of Havana to complete his Bachelor of Arts degree. ${ }^{22}$ A series of affidavits on record at the University of Havana, detail the history of his arrival and early experiences in Cuba. The sworn statements were necessary because of the fire earlier that year, in order to prove his Catholic background, a prerequisite for admission to the university. Having proven his religious and educational qualifications through the testimony of parish priests and other vecinos (townspeople), José Leopoldo Yarini Klupfel was admitted to the University in October 1809 where he successfully completed and validated his surgeon's training the following year. ${ }^{23}$ The last records at the University of Havana indicate he completed his studies in anatomy in 1810. José Leopoldo apparently continued his studies, trying for a full medical degree which he seems not to have completed. ${ }^{24}$

\section{Marrying a Pedigree}

What happened next is difficult to know; however, shortly after his appeal to the University of Havana, José Leopoldo became relatively wealthy and married well-or the

\footnotetext{
${ }^{21}$ AUH, Expediente administrativo, José Yarini Klupfel, 14, No. 961, Folios 4
} and 5.

${ }^{22}$ Yarini's application documents for the University of Havana list him as 30 years of age when he applied. AUH, Expediente administrativo, José Yarini Klupfel, 14, No. 961.

${ }^{23}$ AUH, Expediente administrativo, José Yarini Klupfel, 14, No. 961, Folio 18. Several popular accounts note that José Leopoldo was probably still quite destitute as the legal fee for recording the degree was waived.

${ }^{24}$ AUH, Expediente administrativo, José Yarini Klupfel, 14, No. 961, Folio 20. 
other way around. ${ }^{25}$ In 1812, José Leopoldo married Josefa de Torre Lima, daughter of an influential Matanzas landowner, Don Juan de Torres y Rodríguez-Landin, Regidor y Alcalde Constitucional de Matanzas. ${ }^{26}$ That same year Yarini also relocated to the province of Matanzas as surgeon of the Regimiento de Dragones de Milicias, at the military hospital in that province at a salary of 20 pesos per month. José Leopoldo valued the perks of this military appointment because fifteen years later, in February 1827, although significantly wealthy by that time, he petitioned for a raise because of the large number of patients he was treating. He also requested a new title of médico cirujano (full surgeon). ${ }^{27}$

In Matanzas, the new Yarini family grew even more respected and rich. José Leopoldo had married into provincial power; his work at the military hospital provided him a respectable title, and his connections and business acumen allowed him to accrue significant property and wealth. According to his last will and testament, at the time of his marriage, José Leopoldo already had amassed 30,000 pesos, while his bride, Josefa,

${ }^{25}$ The date and location of the marriage is in question. Sources cite dates of 1812 and 1815, with either Havana (1812) or Matanzas (1815) as the location. Church of Latter Day Saints records list the marriage in Havana in 1812; LDS IGI, v5.0, Batch8768202, Sheet 05, Source No: 1396373.

${ }^{26}$ Francisco Xavier de Santa Cruz y Mallen, Historias de familias cubanas Vol I, (Havana: Editorial Hercules, 1940), 282; LDS IGI, v5.0, IGI, Batch Number 8768202, Sheet 05, Source 1396373. Other sources list Maria Josefa as daughter of the Regidor and Alcalde of Matanzas, Juan de Torre y Rodriguez-Landin, but Don José Lima is listed as Joséfa's father and the godfather of José de Jesús Ignacio Gabriel Yarini y Torres; ACM, Bautismos de blancos, Libro 13, Folio 58v, No. 558.

${ }^{27}$ Within a week of José Leopoldo’s petition in 1827, however, the local authorities decided not to grant him a pay raise or a new title since he already had the title of surgeon of the Regimento de Dragones de Milicias; Archivo Nacional de Cuba (hereafter ANC), Intendencia de Hacienda, Leg. 336/24. 
brought another 10,000 pesos as a dowry into the marriage. ${ }^{28}$ It is highly unlikely that the 30,000 pesos were the result of careful saving, given his lack of funds on arriving in Cuba and the subsequent a salary of 20 pesos per month as a hospital surgeon. Within five years of moving to Matanzas, by 1817 José Leopoldo had acquired an interest in a sugar mill of about 436 acres in the region of Limonar de Guamacaro, in northwest Matanzas, complete with slaves and cattle. Records identify it as the Santa Rosa sugar mill owned by Rafael Caraballo and Gregorio Alfonso "in company with Yarini."29 Founded in 1808, Limonar de Guamacaro was a small settlement of only a dozen houses nestled in the small valley between the two harbor cities of Matanzas and Cardenas. When José Leopoldo bought his share, the Ingenio Santa Rosa was among the smallest sugar mills in the region of Guamacaro, with a maximum sugar production of 312 tons. ${ }^{30}$ The young entrepreneur may have seen the possibilities for growth of the ingenio. The Limonar Valley was ideally situated for sugar production and José Leopoldo’s ingenio was in the middle of the valley. The Camino Real, which connected Havana to Santiago de Cuba in Oriente (Cuba's easternmost province), ran adjacent to Guamacaro and the main access

28 “Testamento de José Yarini Klupfel,” ANC, Escribanía de Luis López Villavicencio, Tomo 10, Folios 199-220v. For a discussion of dowries in Cuban society see Sherry Johnson, "Señoras en sus clases no ordinarias: Enemy Collaborators or Courageous Defenders of the Family," Cuban Studies 34 (2003): 11-37.

${ }^{29}$ ANC, Intendencia de Hacienda, Legajo 336, Expediente 24. In 1829, the name of the ingenio was changed to Rosario and later again to Caridad. Archivo Historico Provincial de Matanzas, Miscelanea de expedientes, comunicaciones de estadísticas agropecuarias, Leg.6/114, in Alberto Perret Ballester, El azúcar en Matanzas y sus dueños en La Habana: apuntes e iconografía (Havana: Editorial Ciencias Sociales, 2007), 167, 338, 468-69. This record included the owners' names and the number of slaves working the ingenio.

${ }^{30}$ Ballester, El azúcar en Matanzas y sus dueños en La Habana: apuntes e iconografía, 167. 
road from the port city of Matanzas ran through the Limonar Valley, making access to export shipping convenient and affordable. By 1828, with the opening of a new export wharf at Cardenas, the Yarini fortune seemed secure.

José Leopoldo’s family had grown along with his fortune and on 8 August 1820 the couple’s first son, José de Jesús Yarini was born. ${ }^{31}$ A second son, José Manuel, was born 28 August 1830 and baptized the following October (with his older brother - age 10—as godfather). ${ }^{32}$ This second child must not have survived as only José de Jesus is named in José Leopoldo’s will in $1839 .{ }^{33}$

José Leopoldo continued to serve with distinction at the Military Hospital in Matanzas for more than 25 years, including during the devastating cholera epidemic that swept the Province in 1833, the first of three epidemics that swept across Cuba during the nineteenth century. ${ }^{34}$ By the time of the outbreak, José Leopoldo was listed as sole

${ }^{31}$ ACM, Bautismos de blancos, Libro 13, Folio 58v, No. 558.

${ }^{32}$ ACM, Bautismos de blancos, Libro16, Folio 160v., No. 679. Another son, José Yarini is reported as born in 1815, in Havana - he apparently also did not survive; LDS IGI, Batch Number 8768202, Sheet 05, Source No. 1396273.

${ }^{33}$ ANC, Protocolos Notariales de la Habana. Protocolo de Luis Lopez Villavicencio, Tomo 10, Folios 199-220.

${ }^{34}$ See José Leopoldo Yarini Klupfel, Relación de Cólera, 1833, for a detailed, if incomplete, account of the cholera epidemic. The document is 260 pages of interesting details including the topography of the region, scientific reflections on Colera-Morbo, Anglo-American and Cuban slave practices, and slave religion, interspersed with quotations from Saavedra, Heredia, Virgil, Dante, and other contemporary and classical authors. It ends suddenly, perhaps attesting to the last pages of the manuscript being lost or destroyed; Klupfel, "Relación de Cólera, 1833.” 
owner of the ingenio which he renamed, Nuestra Senora del Rosario (Our Lady of the Rosary). The cholera epidemic that devastated Cuba’s slaves during 1833 - 1836 decimated plantation populations in western Cuba. Havana's first cases were identified on 25 February 1833, and within a month of the start of the epidemic, the mortality rate in the capital became overwhelming. ${ }^{35}$ The disease's major symptoms are violent and unrelenting diarrhea and vomiting which quickly dehydrate the body and subject the sufferers to excruciating muscle spasms, ruptured capillaries that make bruises appear throughout the body, and an unrelenting thirst. ${ }^{36}$ Within a week of the onset of the disease the patient succumbs to shock and finally death. ${ }^{37}$ A few weeks after the outbreak in 1833 Havana's cemeteries could not contain the dead and nearby estates and parks were called into service in order to bury the corpses. ${ }^{38}$ Within a few short months, February through September 1833, when the Governor General, Mariano Ricafort Palacín y Abarca (1832-1834), sent word to Madrid that the epidemic had abated, cholera had claimed 4200 among Cuba's white population with over five times as many among Afro-

${ }^{35}$ For a discussion of the spread of the cholera epidemic in Cuba see Manuel Salvador Vázquez, "Morbimortalidad colérica en Cuba: la epidemia de 1833 y la permanencia de la enfermedad en la isla (1834-1835)," in Enfermedad y muerte en America y Andalucía, siglos xvi-xx (Seville: Escuela de Estudios Hispanoamericanos, 2004), 283-302; and Mariola Espinosa, Epidemic Invasions: Yellow Fever and the Limits of Cuban Independence, 1878-1930 (Chicago: University of Chicago Press 2009), 10.

36 "El Colera en Guamacaro," in José Leopoldo Yarini Klupfel, "Relación de Cólera, 1833,” Archivo del Museo Nacional de Historia de las Ciencias "Carlos Finlay," Havana, Cuba.

${ }^{37}$ Kenneth F. Kiple, “Cholera and Race in the Caribbean” Journal of Latin American Studies 17 (May, 1995): 161.

${ }^{38}$ José Antonio Saco, Colección de papeles científicos, históricos, políticos, y de otros ramos sobre la isla de Cuba, Vol. 2 (Paris: Imprenta de d'Aubusson y Kugelmann, 1858), 173, 242. 
Cubans, both free and slave (22,700). ${ }^{39}$ William Shaler of Massachusetts, U.S. Consul to Havana from 1829 to1833, for example, succumbed to the disease on 28 March 1833 during the height of the epidemic. Reflecting the shortage of burial grounds and the urgency of burying the dead; the location of his grave remains unknown. ${ }^{40}$ Two weeks after the first cases surfaced in Havana, where it quickly wiped out a tenth of the city's population, the disease was transmitted to Matanzas and most of western Cuba by citydwellers fleeing to the countryside trying to avoid the urban infestations. ${ }^{41}$

The Cholera vibros, coincidentally is spread through unsanitary conditions, when human feces contaminate water and food supplies. The susceptibility of the Afro-Cuban population, in large part, was the result of living conditions on the sugar estates and the

${ }^{39}$ Kiple,"Cholera and Race in the Caribbean," 157-177. In his account of the cholera epidemic, Yarini blames the "Hebrew Cubans" with propagating the idea that blacks were immune to the disease and of storing evidence to the contrary in their "greasy cabinets, the receptacles of usury;” José Yarini Klupfel, "Relación de Cólera, 1833," Archivo del Museo Nacional de Historia de las Ciencias "Carlos Finlay," Havana, Cuba. See also William C. Van Norman, "The Process of Cultural Change Among Cuban Bozales During the Nineteenth Century” The Americas, 62, no. 2 (October 2005): 177-207.

${ }^{40}$ Lawrence Kestenbaum, Political Graveyard: A Database of Historic Cemeteries, "Politicians who died of Cholera, William Shaler," http://politicalgraveyard.com/death/cholera.html (accessed 24 August 2010).

${ }^{41}$ A second epidemic hit Havana in 1852 proceeding from England through New Orleans. The fear was such that the crew and passengers of the Philadelphia were not allowed to enter Havana Harbor but instead were sent to Key West - where they were not allowed to land. After mooring off Sand Key in the Florida Straits, the ship's captain reported on 2 July 1852 that 85 people on board had died, including 26 crew members and that many more were still sick. In 1849, when the Havana Board of Health received word that cases had been reported in New York City, a quarantine of all vessels arriving from the United States was declared but lifted later that same year. By March 1850, the Havana Hospital Militar recorded 66 deaths from cholera. From 1850-1854, 32,000 cases of cholera were reported in Cuba with more than 17,000 dead; Kiple,"Cholera and Race in the Caribbean," 163. 
under-nutrition and malnutrition of most operations. Interestingly, it was perhaps his work as the hero of the cholera epidemic that won José Leopoldo considerable fame in Matanzas. Discovered in the mid-1990s, at the Museo Nacional de Historia de Ciencias in Havana, José Leopoldo's account is a carefully detailed thesis about the arrival of the epidemic in Guamacaro and the consequences of the devastating disease. He quotes from Dante, Virgil and others throughout his elegant treatise which begins with a general introduction of the arrival of cholera in Matanzas; a topic which José Leopoldo noted was much discussed in the local café at the nearby marina. In the opening chapters he also describes the efforts of two recently arrived healers: un "Médico Chino" who provided herbal remedies for his patients, and a British "Doctor Makie” who claimed to be an expert in treating cholera but who instead reportedly left many corpses in his wake. According to the account, more slaves died under Makie's care than when they received no treatment at all. ${ }^{42}$

\footnotetext{
${ }^{42}$ Yarini's ambivalence toward slavery is clear. After a detailed description of the daily lives of slaves, slave master José Leopoldo points to slavery as the root of all illnesses - while continuing to own his slaves. The following chapters (6-11) of the treatise provide a careful recounting of the progress of cholera through the region, noting that the first cases arrived after a devastating storm and hints at a connection between the two. The next six chapters are the story of a single day in the Guamacaro valley's infected sugar mill. At the peak of the epidemic seventeen of Rosario's slaves died in a single night. Chapters 18 to 21 describe the funeral rites and prophylactic measures taken by the slaves to prevent the disease. He also records interviews with slaves about their circumstances. By June 1833, Yarini wanted to restart mill operations and Chapters 2225 recount the return of the slaves from the hills and he adds that although some symptoms remained, for the most part these were mild and treatable. The outbreak at Rosario lasted a mere three weeks. During that time 38 of the ingenio's 129 slaves died. The account ends after 26 chapters with the closing pages missing. The last extant chapter is entitled "To my slaves who died of cholera, year 1833;” Yarini Klupfel, "Relación de Cólera, 1833.”
} 
Interestingly, the savior of the slaves of the ingenio Nuestra Señora del Rosario was also their master; he wrote of the epidemic while also addressing some of the most difficult moral questions on slavery. José Leopoldo lamented the need for slavery and noted that disease and epidemics which were readily controlled on coffee plantations were a certain death-knell for slaves of the ingenios. ${ }^{43}$ He proposed that if he died of cholera he should be buried with his slaves who regarded him as a symbol of safety and assistance by his very presence among them, por la impenetrable égida de mi persona (the shelter of my very presence) ${ }^{44}$ It is possible that Yarini's own son, José Manuel, only two years old when the epidemic swept the region, may have been a casualty of the cholera. The epidemic served another purpose for the planters and merchants, however. Because of the loss of more than 22,000 slaves in little more than 6 months, cholera became a tool in their struggle to justify and perpetuate the contraband slave trade in Cuba.

Coincidentally, census records show the largest upsurge in the non-white population in Cuba during the nineteenth-century occurred between 1827 and $1841 .{ }^{45}$

José Leopoldo's work among the victims of yellow fever and cholera and his tenure at the Military Hospital were not without detractors. In a series of documents filed in the summer of 1834, following Yarini’s extended stay at Rosario tending to the cholera, Antonio Escoto, petitioned military authorities to be named permanent replacement for José Leopoldo as surgeon in the military hospital. Escoto was the next doctor in line for

43 “Los negros de los ingenios,” Klupfel, "Relación de Cólera, 1833.”

44 “El Colera en el Ingo. Nra. Sra. del Rosario de la propiedad del Ber. D. José Yarini autor de estos apuntes,” Yarini Klupfel, "Relación de Cólera, 1833.”

${ }^{45}$ U.S. Dept. of War, Report of the Census of Cuba, 1899, 97. 
promotion at the hospital and had filled in for Yarini for several years. In a petition dated 28 June 1834, Escoto suggests that José Leopoldo “because of his age or more likely because he has a valuable and productive ingenio to which he has devoted his attention, completely abandoned his duties and rarely darkened the doorway of the hospital.” 46 José Leopoldo previously had contracted with Escoto to have him fill in for him at the hospital for 10 pesos per month, half of José Leopoldo's salary (the latter was among the top paid employees of the hospital). Escoto's complaint noted that he was doing all the work for half the money. He added that he would not consider making such a petition if José Leopoldo was in need or in want, but "on the contrary, he is one of the richest landowners in Matanzas and has no need of half the wages that His Majesty grants for the assistance of soldiers at the military hospital, which duty he neglects completely." 47 Escoto had lived with this arrangement for some time, as in October of 1830 he had made a similar petition which had been denied in view of José Leopoldo’s 18 years of service in the military hospital. ${ }^{48}$ In response to the 1834 petition, José Leopoldo responded he had been forced to absent himself from his duties and reside in the country because "since the beginning of the cholera epidemic until its dissipation I was not able to be at the hospital because I was attending to the many sick, whom in those days of terror, I called upon constantly and with courage." ${ }^{49}$ He also boasted that he had a letter from the

${ }^{46}$ ANC, Intendencia General de Hacienda, Leg.337/63, Leg. 337/63, 70, 77 and Leg. 336/24.

${ }^{47}$ ANC, Intendencia General de Hacienda, Leg.337/63.

${ }^{48}$ ANC, Intendencia General de Hacienda, Leg.337/63.

${ }^{49}$ ANC, Intendencia General de Hacienda, Leg.337/63. 
Governor attesting to his valiant and honorable service during the epidemic and which he could produce "when necessary.” By September of that year, Dr. Tomás Pintado had replaced Escoto as José Leopoldo's substitute while the latter was on his estate. Further discussions and petitions must have ensued because by June of the following year, Tomas Pintado, was requesting he be awarded the post (and salary) of surgeon at the Hospital Militar since José Leopoldo remained absent from his duties. ${ }^{50}$ Escoto and his petition were not mentioned.

José Leopoldo’s last will and testament, dated 1839, recorded on his deathbed, noted that he was sole owner of the ingenio Nuestra Señora del Rosario in Guamacaro, Matanzas (See Table 1: Ownership of the Yarini Ingenio in Guamacaro). ${ }^{51}$

${ }^{50}$ ANC, Intendencia General de Hacienda, Leg. 337/77

51 The record shows the will was prepared on March 31, the day before José Leopoldo's death. This entry also shows his age at the time of death as 50 years old, corroborating the documents from the University of Havana as to his date of birth as 1789; AUH, Expediente administrativo, José Yarini Klupfel, 14, No. 961, and ACM, Entierros de blancos, Libro 9, Folio 194v, No. 1335. 
Table 1

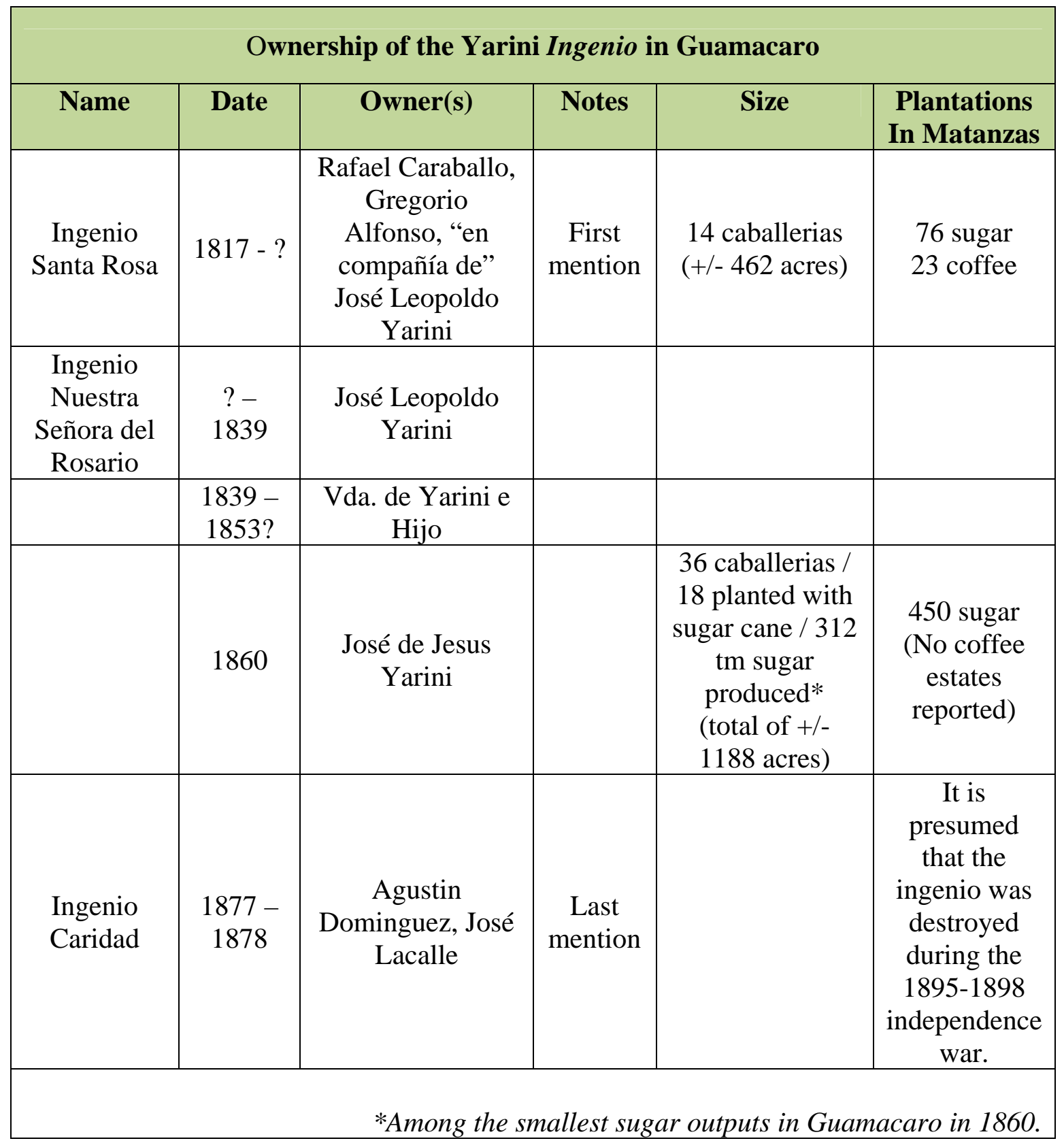

Source: Alberto Perret Ballester, El azúcar en Matanzas y sus dueños en La Habana: apuntes e iconografía (Havana: Editorial Ciencias sociales, 2007), 167, 338, 468469. 
By then the ingenio consisted of almost 1300 acres, housed 120 slaves, and boasted numerous heads of livestock. ${ }^{52}$ The will also recorded that José Leopoldo owned four houses in town: three of block and mortar, one of boards and "all with clay-tiled roofs," in addition, he had three servants, furniture, gold and silver. The will named his son, José de Jesús, his sole heir and Don Simon de Ximenes as his guardian. Perhaps acknowledging her own business acumen, José Leopoldo named his wife, Josefa, as the executor of his will noting his son, José de Jesús, was not yet of age (about 19 years old at the time).$^{53}$ Three town residents witnessed the will including Dr. Don Tomás Pintado, José Leopoldo’s replacement at the Hospital Militar. The date of signature for the will is not legible, however, the wording suggests Don José was on his death bed. The marginal notation by Luis Lopes de Vallvicencio indicated that José Leopoldo Yarini Klupfel died on 3 April 1839. The death certificate was subsequently recorded at the Matanzas Cathedral. The provisions of the will made José de Jesús a desirable catch for a Matanzas socialite.

${ }^{52}$ In Spain and countries settled by the Spanish, a caballería was a land measure of varying size. In Cuba it consists of about 33 acres, while in Puerto Rico and the Southwestern United States, about 194 and 108 acres respectively; Webster's Revised Unabridged Dictionary (Springfield, MA: C. \& G. Merriam Co., 1996). The estate was 38 and $3 / 4$ caballerias. Using this measure, the estate would be about 1300 acres; Ballester, El azúcar en Matanzas y sus dueños en La Habana: apuntes e iconografía, 167.

${ }^{53}$ AUH, Expediente administrativo, José Yarini Klupfel, 14, No. 961. The Matanzas parochial burial register records José Yarini’s burial “at age 50” in 1839. ACM, Entierros de blancos, Libro 9, Folio 194-195v, No. 1335. The practice of women serving as guardians and executors of wills had become accepted in Spanish military society at the time because the men were absent and off to service. For a discussion on women as independent actors assuming responsibilities usually reserved for men in colonial society see Johnson, "Señoras en sus clases no ordinarias," 11-37. 


\section{Ponce de León}

María de la Concepción Ponce de León Heredero, was the daughter of a well-respected Matanzas military family with distinguished ancestors that included a peninsular Secretary of War and a Lieutenant General. ${ }^{54}$ While not descendants of the legendary Juan Ponce de León, Maria’s family added legitimacy and respectability to the Yarini name. ${ }^{55}$ During the seventeenth century, the family patriarch, Don Patricio, had served as Teniente Colonel del Regimiento de Valladolid and as Regidor Perpetuo y Caballero de la Orden de Santiago. His son, Don Francisco, served as administrator of the Rentas Reales in Jerez de la Frontera. The first of this branch of the Ponce de León family to arrive in Cuba, Don José Ponce de León y Fantoni landed in Havana from Algeciras, Spain, at the close of the eighteenth century, and registered his pedigree in Havana on 23 November 1792. ${ }^{56}$ Soon widowed after his arrival, Don José Ponce de León was married a second time on 13 December 1810 to Teresa Jesús de Heredero. The couple probably moved to Matanzas shortly thereafter where their daughter, María de la Concepción, was born. Part of a "titled” Matanzas elite, the Ponce de León s mingled with government

54 José Leopoldo Yarini y Ponce de León ’s birth record in 1842 lists his mother, María de la Concepción Ponce de León Heredero, as born in Guanabacoa a township in eastern Havana bordering Matanzas; Archivo Parroquial de la Iglesia de Termino de San Carlos de Matanzas, Bautismos de blancos, Libro 27, Alforja 210, No. 826.

55 The Yarini and Ponce de León family names are linked in marriage in 1859; see Fernando Suárez de Tangíl y de Angúlo, conde de Vallellano, Nobiliario cubano: o, las grandes familias isleñas, por el conde de Vallellano, Vol. 2 (Madrid: F Beltrán, 1929).

${ }^{56}$ In these documents José Ponce de León attested to being a descendant of a distinguished military family including a Captain in the Real Armada, a Lt. General in the same, a Secretary of War, and a Caballero de la orden de Santiago; see Francisco Xavier de Santa Cruz y Mallen, Historias de Familias Cubanas, Vol. 1 (Havana: Editorial Hercules, 1940), 281-83. 
officials and military officers. A union between the Yarini and Ponce de León families had handsome implications for both sides. José de Jesus had a significant inheritance and Maria de la Concepción a peninsular pedigree. On 17 June 1841, José de Jesús Yarini Torre, José Leopoldo’s only surviving son, and Concepción Ponce de León Heredero were married in the Matanzas Cathedral. ${ }^{57}$ José de Jesús and María de la Concepción, both first generation Cubans, had at least four sons: José Leopoldo (b. 1842), named for his illustrious Klupfel grandfather; Cirilo José Aniceto (b. 1848) named, after his maternal uncle; Alberto L. Yarini (b. 1851); and José Manuel (b. 1854) ${ }^{58}$

After the death of José Leopoldo, a series of socio-economic hardships had struck the ingenios of Matanzas. On the heels of the decimating cholera epidemic of 1833, three devastating hurricanes in close proximity during the 1840s (1842, 1844 and 1846) virtually destroyed both coffee and sugar production in Guamacaro, opening opportunities for foreign investment in land and agricultural production. The destruction brought on by the hurricanes led to slave insurrections as $85 \%$ of slave living quarters collapsed, food was scarce, and production disrupted. The hurricanes' aftermath went far beyond economic considerations and also had powerful social and political repercussions for aspirations of nationhood as scarcity and uncertainty fueled unrest in the rural regions of the country. ${ }^{59}$ By 1860 , competition for sugar dollars had more than quadrupled in the

${ }^{57}$ Santa Cruz y Mallen, Historias de Familias Cubanas, 282.

${ }^{58}$ Archivo Parroquial de la Iglesia de Termino de San Carlos de Matanzas, Bautismos de blancos, Libro 27, Alforja 210, No. 826.

${ }^{59}$ In an analysis of the specific impact of three strong hurricanes on western Cuba in 1842, 1844, and 1846, Perez offers a new perspective on the role of hurricanes on the formation of the Cuban nation and culture; Louis A. Perez. Jr., Winds of Change: 
Matanzas sugar partidos, with nearly 450 ingenios operating ( up from 76 in 1817) as ruined coffee plantations were quickly transformed into more lucrative sugar cane fields. ${ }^{60}$ The Yarini's neighbor, the Saint-Domingue-born John Chartrand, for example, transformed his coffee plantation (El Laberinto) into a prosperous ingenio (La Ariadne) after the hurricanes of the 1840 s. ${ }^{61}$ Such stiff competition made life in Matanzas less than desirable for second and third generation Yarinis. Rising anti-Spanish unrest among Cubans resulted in the outbreak of the Ten Years War (1868-1878) and the resultant raids and instability were perhaps the last straw which propelled the Yarinis to leave their Matanzas patrimony. These developments, added to the meager and contentious pay at country hospitals, made the once-idyllic valley of Guamacaro less and less desirable for a family of doctors, no matter how gentrified.

Hurricanes and the Transformation of Nineteenth-Century Cuba (Chapel Hill: University of North Carolina Press, 2001).

${ }^{60}$ One of Yarini's neighbors in Guamacaro was John Chartrand, who arrived in the valley in the mid 1820s as the owner of the Ariadne coffee plantation near Limonar (perhaps inherited from an uncle). His French parents had fled Saint Domingue during the 1790s and had found a refuge in Charleston, South Carolina from where John had made his way to Matanzas and changed the name to 'El Laberinto' (The Labyrinth). During the devastating hurricanes of the mid-1840's, Chartrand then rebuilt the plantation into the highly successful ingenio"La Ariadne" which continued to expand in the Guamacaro valley. John Chartrand's sons, Esteban and Philippe, became well repected Cuban painters whose best known images include landscapes featuring ingenios of the mid-eighteenth centuries; see "Colera en el ingenio," http://www.thefullwiki.org/wiki//C\%C3\%B3lera_en_el_Ingenio (acessed 25 June 2009). The plantation was reportedly completely destroyed during the Spanish-Cuban-American war.

${ }^{61}$ For a discussion of the effects of the revolution in Haiti on politics and society in Cuba, see Louis A. Perez, Jr., Between Reform and Revolution (1988); Hugh Thomas, The Cuban Revolution; and Ada Ferrer, "Social Aspects of Cuban Nationalism." 
By the time of Doña Josefa's death around 1853, the ingenio's land holdings had more than doubled from 14 to 36 caballerias. Interestingly, provincial records show that Doña Joséfa, José Leopoldo’s widow, remained listed as co-owner of the ingenio Nuestra Señora del Rosario, along with her son José de Jesús from 1839 until 1853 - probably the year of her death. ${ }^{62}$ Seven years later, in 1860, when José de Jesús Yarini Torre was finally listed as sole owner of the ingenio, Rosario recorded the lowest production of sugar in the Partido Guamacaro, with only half its acreage planted in sugar cane. ${ }^{63}$ Sometime during the decade that followed, José de Jesús sold the ingenio and moved the family to Havana. Records show that at least from 1877 to 1878, the ingenio was owned by Augustin Dominguez and José Lacalle, its last recorded owners. ${ }^{64}$ There is no further mention of the ingenio in extant documents probably indicating its destruction or decommission during the independence struggles at the close of the nineteenth century that took a toll on rural estates. (See Table 1: Ownership of the Yarini Ingenio in Guamacaro.)

${ }^{62}$ Ballester, El azúcar en Matanzas y sus dueños en La Habana 470.

63 This account contains a full list of ingenios in Cuba and provides the owner's name, size of labor force, type of train used, property size, location of export dock, distance to wharf, and production of sugar for 1859 and 1860; Carlos Rebello, Estados relativos a la producción azucarera de la isla de Cuba, formados competentes y con la autorización de la intendencia del Ejército de Hacienda (Havana: Imprenta del Gobierno, 1860), cited in Ballester, El azúcar en Matanzas y sus dueños en La Habana , 468.

${ }^{64}$ From José Mauricio Quintero y Almeida, Apuntes para la historia de la Isla de Cuba con relación a la ciudad de Matanzas desde el año 1693 al de 1877 (Matanzas: Imprenta El Ferrocarril, 1878). This publication includes 134 ingenios and their división into 6 partidos and includes the names of owners; cited in Ballester, El azúcar en Matanzas y sus dueños en La Habana, 338, 466, 468. 


\section{Move to Havana}

Moving to Havana, the Yarinis landed on their feet once again. It is not entirely clear when or why the family relocated to Havana in the last quarter of the nineteenth century but it was probably in the mid-1870s after the sale of the ingenio or as the result of the ruinous tactics of independence war forces pillaging the Matanzas countryside. ${ }^{65}$ The four Yarini sons followed their father and grandfather in pursuing a medical career at the University of Havana. Before long they became distinguished doctors, professors and surgeons. The Yarini family had made the transition to full time life as bourgeoisie Havana elite and was comfortably, if not sumptuously, settled in the trendy Vedado section of the city, leaving the Matanzas country life behind.

The oldest of the Yarini sons, José Leopoldo (b. 1842) by 1865 held a degree from the Instituto de Segunda Ensenanzas in Matanzas and in 1872 received a degree as Doctor en Derecho y Medicina y Cirugia from the University of Havana. In 1881 he was named Assistant Professor in the School of Medicine at the university and four years later presented his credentials to become Chair (Catedra) of the department of Osteology and Dissection. ${ }^{66}$ After working at the university for 25 years, publishing numerous books and papers which were adopted for use in the study of medicine at the university,

${ }^{65}$ The effects of the independence wars on the Cuban countryside are discussed in more detail in Chapter 3.

${ }^{66}$ AUH, Expediente administrativo, José Leopoldo Yarini Ponce de León, 14, No. 964. A second entry contains José Leopoldo's doctoral thesis and the review board's comments and conclusions which commended José Leopoldo for his professionalism and "persona;" applications to the crown for promotion and approval of instructional theses and the tenure and promotion records for José Leopoldo Yarini; Madrid, Archivo Historico Nacional (hereafter AHN), Ultramar, Expediente Administrativo, José Leopoldo Yarini Ponce de Leon, 263, Exp 14 (1871); Exp 11 (1890); Exp15 (1893). 
including a five-volume textbook, Tratado de Técnicas de Anatomía General del Cuerpo Humano (1893). ${ }^{67}$ José Leopoldo died in 1898 and shortly thereafter, the university’s teaching hospital, and probably the most important hospital in Havana, the Hospital Nacional General Calixto García, named its internal medicine ward after José Leopoldo Yarini y Ponce de León . ${ }^{68}$

A year after his oldest brother's graduation, in 1872, Cirilo José applied to the University of Havana to study dental surgery. ${ }^{69}$ After graduating, Cirilo also enjoyed an illustrious university career and in 1900, after a dutiful appeal to authoritties for promotion, was named chair of the department of dental surgery at the university where he continued his research and teaching duties until his death in February 1915. The respect of his colleagues and of his illustrious career was evident; when he died, the university president ordered flags flown at half mast and all the balconies of the university's major buildings draped in black until after the internment of "such an illustrious professor.,"70 A

\footnotetext{
${ }^{67}$ Washington Rosell Puig and Ena Paneque Ramos, Evolución histórica de la enseñanza de la Anatomía en Cuba, Facultad de Ciencias Médicas "Dr. Enrique Cabrera,” (Havana, 30 March 2007).

${ }^{68}$ Other notable cátedras of the UH School of Medicine with named pavilions include the following; surgery (salas Mestre, Enrique López, San Martín, Costales, Fortún y Salón Menocal), internal medicine (Weiss, Torralbas, Landeta, Yarini,), dermatology (Luaces), parasitology (Domingo Cubas), obstetrics (Enrique Núñez), medical law (Carlos M. Céspedes), and psychiatry (Valdés-Anciano), hematology (Alberto Recio). Delgado G. García, "Hospital Clinico Quirúrgico Docente General Calixto Garíia, Recuento Histórico en su centenario,” Boletin Hospital Docente “General. Calixto García 13-14, Number 1-2 (1998- 1999): 57-60 http://www.sld.cu/uvs, accessed 25 August 2010.

${ }^{69}$ AUH Expediente administrativo, Cirilo Aniceto Yarini Ponce de León, 14, No. 963, (1881).

${ }^{70}$ AUH, Expediente administrativo, José Leopoldo Yarini, 14, No.319.
} 
third brother, José Manuel (b. 1854), applied to the University of Havana’s dental school in 1874 and followed up in 1878 with his application to graduate in oral surgery, following in the family's footsteps. Little is known about the fourth Yarini brother, Alberto Leopoldo (b. 1851).

The oldest Yarini brother was the scholar, while Cirilo, as next in line, seemed to watch over the youngest two brothers. While taking his degree at the University of Havana, in 1875, Cirilo visited New York City and took the opportunity to apply for a passport as a "naturalized and loyal citizen of the United States," a process reportedly often used by Cuban elites to avoid paying taxes. His younger brother Alberto (age 24) accompanied him and also applied for a passport at the same time. The taller of the two, Cirilo was said to be handsome and elegant, his passport application lists him as having an olive complexion with dark brown hair and eyes, while Alberto, a good two inches shorter, was of fair complexion and sported a fashionable moustache. Their applications noted they both shared one characteristic: a prominent nose. ${ }^{71}$

With the family settled in Havana and with a university degree within reach, in 1877, the handsome Cirilo married his cousin, Juana Emilia "Mimí” Ponce de León, at the Parish Church of Monserrat on Galiano Street. ${ }^{72}$ The Yarini's place of worship was home to a diverse group of habaneros. Dedicated in 1843, the church of Our Lady of Monserrat,

${ }^{71}$ NARA, National Archives Microfilm Publication M1372, General Records of the Department of State, Record Group 59, U.S. Passport applications, 1795-1925 records of Cirilo A. Yarini and Alberto L. Yarini.

${ }^{72}$ Archivo Parroquial de Monserrate (hereafter APM), Matrimonios de blancos, Libro 6, Folio 227, No. 376. The birth of Yarini's brother and sister could not be verified as Libro 16 of baptisms was missing from the Church archives. 
paradoxically served as parish for the affluent, who married, baptized and held funeral masses at Monserrat -Cuban patriot José Martí's parents were married there, and his sisters and son were baptized in Monserrat's chapel. The church also recorded the marriage of Dr. Juan Carlos Finlay (1865), Cuban physician and scientist recognized as a pioneer in yellow fever research and seven-time nominee for the Nobel Prize in medicine, and of two future presidents of the Cuban Republic, Laredo Bru (m. 1901), Alfredo Zayas (m. 1914). ${ }^{73}$ In addition, because it bordered the oldest parts of the city, Monserrat's parishioners also included members of the marginal sectors of society that called the streets of the neighboring working class district of San Isidro home: immigrants, laborers, petty criminals, and prostitutes.

Cirilo’s new bride, Emilia, was reportedly quite a catch. An accomplished pianist who was rumored to have performed at the French court for Napoleon III as a young girl, Mimí was described as tall and elegant, educated and sensible. Along with the Ponce de León pedigree, she was a desirable match for the son of such a distinguished and erudite family. ${ }^{74}$ Emilia's mother, Monserrate, was the self-proclaimed Marquesa de Aguas Claras, although probably through some dubious, and at best convoluted, genealogy. ${ }^{75}$ Although not among the richest of Havana's families, the Yarinis possessed the socioeconomic status that allowed them to enjoy the benefits of the upper middle class. The

${ }^{73}$ Memoria del Primer Centenario de la edificacion y apertura al culto de la hermita, luego parroquia de Nuestra Señora de Monserrat (Habana: Molina y Cía., 1944), 23-28.

74 "Interview with Cesar García," (Emilia Yarini’s first cousin), in Cañizares, San Isidro, 1910, 13, 37, 40.

${ }^{75}$ Cañizares, San Isidro, 1910, 38, 41. 
scientific-professional achievements of the men in the family allowed them to move in intellectual circles; their pedigree and family connections through the Ponce de León women provided entry into Havana's elite society. This interaction placed the Yarinis at the hub of Havana social circles after the turn of the twentieth century, mingling with politicians, thinkers, and revolutionary war heroes. 
Cirilo and "Mimí" had three children - the oldest, Cirilo ("Cirilito") José Anastasio was born on 2 May 1879 and the second, Emilia Maria Mauricia ("Cuca”), the following year. The third, Alberto Manuel Francisco, reportedly his mother's favorite, was born on 5 February $1882 .^{76}$ Little is known about the children's early educational. It could be deduced, however, that given the family's emphasis on education and their social standing, they subscribed to the popular method of educating young people in Havana at the time including several years in U.S. boarding schools. Popular lore suggests that the boys studied at the prestigious Colegio de San Melitón in Havana and then were sent to the United States to complete their education. ${ }^{77}$

The family often traveled to the United States including New York, Key West and New Orleans for business and pleasure. The oldest son, Cirilito, had gone to New York in 1896 probably to begin his studies in dental surgery and by 1900, had applied for his examination as a dental surgeon at the University of Havana, paying the $\$ 25$ fee in "American gold coins."78 In 1902, Cirilito was listed as a member of the faculty at the

${ }^{76}$ APM, Libro de Bautizos, Libro 17, No.45; Cañizares, San Isidro, 1910, 37.

${ }^{77}$ See Rafael Soto Paz, "Yarini: su mundo y su muerte,” Bohemia, 18 February 1949.

${ }^{78}$ Passenger lists for Havana indicate that 16-year-old Cirilo José left for New York on 20 January 1896, and again Steamship records for 1897 show him traveling alone as a "student" to the port of New Orleans; NARA, Micropublication, M259, RG036, National Archives Series T905-4, Passenger Lists of Vessels Arriving in New Orleans Louisiana, 1903-1945. The following pages detail the examination procedures: Cirilo implanted a tooth successfully on a patient in the office of Dr. Dod. A decade later, Cirilo took the examination to become a Dr. in Dental Surgery and was awarded his title on 6 August 1910; AUH, Expediente administrativo, Cirilo Yarini y Ponce de Leon, 9, No.874. 
University of Havana and before long, successful and respected, was living above his dental offices at No. 16 Galiano Street, in one of Havana's genteel neighborhoods. ${ }^{79}$

In 1900, the extended Yarini family was a Who's Who of Havana respectability. ${ }^{80}$ Cirilo José Aniceto Yarini, was a respected dental surgeon in the city, a founding member of the School of Dental Surgery (1900) and of the Sociedad de Odontologia in Havana; in addition, he was a tenured full professor (catedratico titular) at the University of Havana, and served as representative for the university before U.S. occupation governor, Leonard Wood. ${ }^{81}$ José Leopoldo (the oldest brother,) was a medical author and surgeon with a ward named after him in the Hospital General Calixto Garcia. Brother Alberto José, was also a respected dental surgeon with a significant practice in Havana. With Cirilito's appointment to the university faculty and his successful dental practice, a new generation of Yarini’s was joining their ranks.

The Yarini family was very comfortable and respected in Havana's most polite society and the family's many trips suppose a close affinity to the U.S. ${ }^{82}$ In 1901 the elder

${ }^{79}$ Advertisement for dental services, Bohemia, November 1902, 72.

${ }^{80}$ The Yarini name on a frieze at the university is still visible today and was probably inscribed on the façade in 1941 when the university was expanded.

${ }^{81}$ J.A. Foyo Martinez-Fortun, "Apuntes para la historia de la odontologia en Cuba," Cuadernos de Historia de Salud Publica, 23 (1963): 11-85. See also Felix Companioni Landin, "Aniversario 99 de la escuela de Cirugia dental en la Habana," Revista Cubana Estomatal 37, No.1 (2000): 67-71.

${ }^{82}$ Cirilo traveled to New York on 19 July 1904 aboard the Morro Castle, a steamship built for the New York \& Cuba Mail Steamship Co.; Ellis Island Foundation, Ellis Island Ship Database, "Morro Castle," http://www.ellisisland.org/search/passRecord.asp/letter=m\&half=2\&sname=Morro*Castl e (accessed September 6, 2010). Cirilo’s brother, José Yarini (age 33), arrived aboard 
Cirilo once again visited New York, with the express purpose of visiting dental surgery schools, perhaps hoping to have his youngest son, Alberto, follow in the family tradition. ${ }^{83}$ Although the family trips to the U.S. continued, during the next few yearsin 1904, the elder Cirilo visited New York once more while José de Jesus visited New Orleans, and Emilia Yarini visited New York in 1905-Alberto's education seemed to have come to a halt in his mid-teens as no further mention is made of a degree or university affiliation. While little is known of his youth, he probably followed a similar educational and social path as his older brother Cirilo, lacking for nothing. He reportedly also attended San Melitón, an obligatory way station for any young man in Havana’s highest social circles. At the all-boys school for young men of the upper classes, he reportedly took great pleasure in practicing tennis and excelled in boxing. ${ }^{84}$ Testimonies of those who knew Alberto speak of his reputation as a self-controlled young man of few words, who never raised his voice, and walked with an air of assurance and poise. ${ }^{85}$ His doting mother reportedly spoiled him, even buying him a stunning white stallion on

the Excelsior on 7 July 1904; National Archives Washington, D.C., Passenger Lists of Vessels Arriving in New Orleans Louisiana, 1903-1945, Micropublication M259, RG036, Series T905-4.

${ }^{83}$ AUH, Expediente administrativo, Cirilo Yarini Ponce de León, 14, No. 319.

${ }^{84}$ Cañizares, San Isidro, 1910, 39.

${ }^{85}$ These interviews, however, were conducted in the 1970s and may be partially influenced by the mythology that had already developed as a result of Yarini’s murder; Dulcila Cañizares, San Isidro, 1910: Alberto Yarini y su época (Havana: Editorial Letras Cubanas, 2000) and Tomas Fernández Robaina, Historias de Mujeres Publicas (Havana: Editorial Letras Cubanas), 1998. 
which he could ride to his political meetings. ${ }^{86}$ Alberto apparently never enrolled in university studies, but instead, perhaps influenced by the failure of Cuba's colonial and neo-republican institutions, made a different career choice. His last documented trip to the U.S. was when he returned to Havana via Mobile on 29 March 1906 when he was 24 years old. ${ }^{87}$ By that time he had established his reputation in a new profession for the Yarini family.

\section{Conclusion}

It is indisputable that Alberto Yarini y Ponce de León grew up as a privileged young Cuban socialite. A fourth-generation Cuban, he no doubt had heard of his great grandfather's exploits and determination to “make America” which had left the family financially comfortable. (See Table 2, Family Tree for Alberto Yarini y Ponce de Leon.) He was the offspring of three generations of Yarinis who had risen in social standing because of their professions and well-placed marriages.

Yarini had all the accoutrements of respectability. Yarini, however, came of age at a time of deep crisis in the formation of a Cuban nation, a time of dramatic and violent change in Cuba. Too young to participate in the war of 1898, during his first two decades of his

${ }^{86}$ This is only one account of how he got his horse; the stories about him, however, always include Yarini's ownership of a white horse. Cañizares, San Isidro, 1910, 38-39; 54.

${ }^{87}$ ANC, “Libro de salida de pasajeros de la Aduana de la Habana,” Libro de Registro, 1906. From the early 1800s, there were a number of small Cuban communities in the United States in cities such as New York, New Orleans, Philadelphia, and Charleston; see Kenya Dworkin y Mendez "La patria que nace de lejos: Cuba y lo cubano en la vanguardia de Martí,” Cuban Studies 36 (2005): 1-22. 
life Yarini nevertheless witnessed the end of slavery, heard the ambivalent and ineffective political debates of the autonomists, annexationists and independents about the political future that was best for Cuba, watched the ultimate demise of the Spanish colonial system, and experienced the U.S. occupation of a "free" Cuba first hand. By the time he was 16 years old, Alberto had witnessed the demise of every economic, social, racial, and political institution he had known. At the beginning of the twentieth century, Havana, the city that had welcomed his grandfather and provided opportunities for subsequent generations, was in complete fiscal disarray and embroiled in bitter internal political and racial quarrels. 
Figure 2

Family Tree for Alberto Yarini Ponce de León

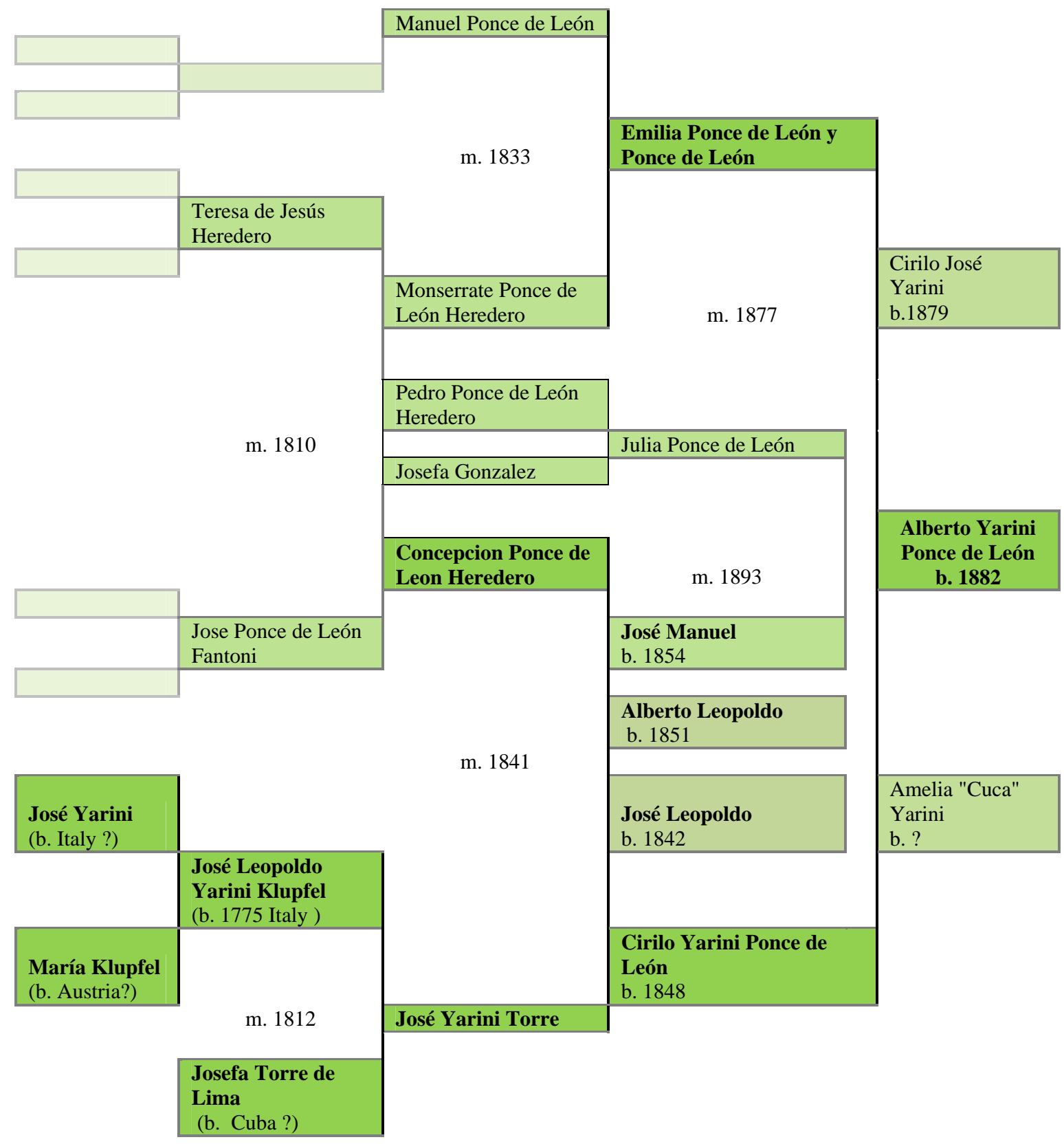




\title{
CHAPTER III
}

\section{“LA PATRIA PEQUEÑA"1 : HAVANA}

\author{
Cuando a la Habana fuí \\ cuando la mar crucé \\ nunca desfallecí, pero al llegar me mareé. ${ }^{2}$
}

In 1899, the seventeen year old Alberto Yarini y Ponce de León’s coming of age was set against the backdrop of a nascent republic physically and ideologically struggling to establish itself as a nation. The abolition of slavery by royal decree in 1880 and the subsequent end of the patronato (forced tutelage) of ex-slaves by their former owners in 1886 had precipitated the realignment of social structures along racial and social lines as former slaves were suddenly "members" of a new class of impoverished farmers and urban laborers in a "free" Cuba. ${ }^{3}$ The three-year struggle for independence from Spain

${ }^{1}$ Hugh Bradley, Havana: Cinderella’s City (New York: Doubleday, Doran and Company, 1941) 402.

2 "When to Havana I traveled/while the sea I did cross/I never was discouraged, but after I arrived I was nauseous (seasick),” from “Habanera de Cuba,” (no date), Colección Cancionera, La Tuna, http://tuna.upv.es, accessed 2 October 2010.

${ }^{3}$ In 1880, the Spanish Cortés approved an abolition law for Cuba which provided for an eight-year period of patronato approved an abolition law (1880) that mandated for an eight-year transition period for all freed slaves and required they continue working for their ex-owners at no charge. The royal decree of 7 October 1886 abolished slavery completely and ended patronato. Hugh Thomas, Cuba, or The Pursuit of Freedom (New York: Harper and Row, 1971), 279. 
(1895-1898) also wreaked havoc on economic and political institutions. ${ }^{4}$ Plantations in the Cuban countryside were either destroyed by scorched earth war tactics or ruined by the desertion of their Afro-Cuban labor force. As a result, many impoverished landowners sold off their holdings and a small but economically powerful upper class who controlled much of the official power structures emerged. Foreign investors-most from the U.S. - vied to also buy up all available land. ${ }^{5}$ An accompanying oversupply of laborers both in the city and the countryside also led to the rise of labor unrest and the formation of labor organizing movements including among the cigar makers, artisans, and iron workers. ${ }^{6}$ The onset of U.S. occupation after 1898 added still another facet to the ambivalence of emerging identity and sovereignty. Cuban public opinion was sharply divided on the U.S. intervention, with some hailing the Americans as saviors and others as the reincarnation of Spanish control. ${ }^{7}$

${ }^{4}$ John Lawrence Tone, War and Genocide in Cuba, 1895-1898 (Chapel Hill: University of North Carolina Press, 2006).

${ }^{5}$ In 1898 U.S. citizens already owned more than $\$ 50$ million of Cuban real estate. During the first decade after independence, approximately forty-two land development and colonization companies from across the United States (including one from South Dakota) were in operation in Cuba. For a listing of companies from 1898-1912, including location of incorporation in the U.S. and area of operation in Cuba, see Perez, On Becoming Cuban, 510. For a discussion of the development of U.S.-Cuba commercial networks in the first two decades of the twentieth century and their impact on the development of the Cuban republic, see Juan C. Santamarina, "The Cuba Company and the Expansion of American Business in Cuba, 1898-1915," Business History Review 74, No. 1 (Spring, 2000): 41-83.

${ }^{6}$ See Joan Casanovas, Bread or Bullets: Urban Labor and Spanish Colonialism in Cuba, 1850-1898 (Pittsburgh: University of Pittsburgh Press, 1998); and Helg, Our Rightful Share.

${ }^{7}$ On 10 December 1898 Spain and the United States signed the Treaty of Paris. The treaty provided that Spain renounce all rights to Cuba, Puerto Rico, the Philippines 
By 1901 having elected its first President and with the promise of a Cuban nation at last materializing with the impending withdrawal of U.S. forces planned for 1902, Cuba nevertheless, reeled in the aftermath of a devastating independence struggle and three years of imposed U.S. control. Citizens of the newly "independent” nation, and in particular its capital, were plagued by a dogged ambivalence manifested in large part in confused rhetoric with and about the role of the United States in a Cuba libre, dramatic shifts in the social framework, at times violent racial tension and an embryonic and conflicted sense of cubanidad. ${ }^{8}$ As seen in its main pre-independence ideological constructs - autonomista, annexationism, separatism — the issue of cubanidad had been long-debated, but the dissonance had resulted in an unresolved national identity crisis. Coming of age in the tumult of the post-1898 years, a young Alberto Yarini countered the instability that plagued visions of cubanidad and created his own version of identity for the imagined nation. The nation's ambivalence also provided a stage for him to play out his "public man” aspirations and to construct an "other” in the U.S. that would suit his political purposes.

and Guam. No Cuban representative was present at the signing and while the treaty officially granted Cuba its independence, and the U.S. flag, not the Cuban flag, was raised over Havana. An official ceremony marked the transfer of power from Spain to the U.S. was held on 1 January 1899 when the U.S. flag was raised over El Morro Fortress at the entrance to Habana's great harbor. The symbolism was not lost on the Cubans; Marial Iglesias Utset, "Imágenes en Conflicto: Cuba y la presencia imperial norteamericana (1898-1902)," in An Intimate and Contested Relation: The United States and Cuba in the Late Nineteenth and Early Twentieth Centuries , Alessandra Lorini, ed, (Florence: Firenze University Press, 2005), 32-53

${ }^{8}$ Philip S. Foner, A History of Cuba and its Relations with the United States, Vol 2 (New York: International Publishers, 1963); and Philip S. The Southern Dream of a Caribbean Empire 1854-1961 (Baton Rouge: Louisiana State University Press, 1973). 


\section{Northern Suitors}

The long-standing discourse about Cuba in the United States dated back to before the U.S.’s own revolutionary war and U. S. interests had long kept a watchful eye on developments in Cuba. For example, in a letter to President James Monroe, dated 24 October 1823, Thomas Jefferson remarked that he "ever looked at Cuba as the most interesting addition that could be made to our system of States." ${ }^{9}$ Throughout the 1840s and 1850s, fueled by the rise of Manifest Destiny and coupled with fears of the spread of slave insurrections, some argued the U.S. had providential rights to Cuba (and to other regions such as Haiti and Mexico). For example, through Congressional debates and articles in the popular press, U.S. citizens implored the government to rescue Cuba from European despotism. ${ }^{10}$ Cuba's annexation also became a ploy in the pro-slavery debate which proposed controlling Cuba's large African population as the only way to ensure the survival of slavery for the U.S. A treatise on the right of U.S. annexation of Cuba published in the 1850s even went so far as to argue that disregarding Cuba was a threat to "white life and institutions in the South."11 While welcomed by Cuban Annexationists,

${ }^{9}$ James Buchanan, J. Y. Mason and Pierre Soule,“The Ostend Manifesto,” from the House Executive Documents, 33 Cong., 2 Sess., Vol. X, pp. 127-136, http://xroads.virginia.edu/ hyper/hns/ostend/ostend.html (accessed 20 March 2003).

${ }^{10}$ See for example, "Continental Policy of the United States - the Acquisition of Cuba,” The United States Democratic Review 43, no. 1 (April, 1859), 2.

${ }^{11}$ Eric Sundquist, "Slavery, Revolution, and the American Renaissance," in Walter Benn Michaels and Donald E. Pease, eds., The American Renaissance Reconsidered (Baltimore, MD: Johns Hopkins Press, 1989), 12. For a novel highlighting U.S. - Cuba relations and racial questions in the U.S., see Martin Robison Delaney, Blake: Or the Huts of America, Floyd J. Miller, ed., (Boston: Beacon Press, 1970). 
these pleas fell largely on deaf ears as Congress was reticent to undertake such a public, international relations tussle.

By the 1850s, when more than 5,000 U.S. citizens traveled to Cuba annually for business and pleasure, the debate grew heated. In 1853, after being elected President Franklin Pierce alluded to Cuba his inaugural speech as “certain possessions not within our jurisdiction eminently important for our protection.” ${ }^{12}$ Throughout the nineteenth century, U.S. Congressmen repeatedly called for the outright purchase of Cuba, offering a price that rose steadily from approximately $\$ 30$ million in the 1820 s, to $\$ 100$ million in 1848, and $\$ 130$ million by $1854{ }^{13}$ In contrast to overtures to buy Cuba, the Ostend Manifesto of 1854 advocated outright seizure of Cuba, its authors fearing a Cuban slave rebellion that would inspire U.S. slaves to also rebel. The Manifesto claimed that "considerations exist which render delay in the acquisition of the Island exceedingly dangerous to the United States." ${ }^{\text {14 }}$

Later, U.S. historians reflected that during the mid-nineteenth century the desire to include Cuba as part of the expected American empire was such that some proposed, "if

${ }^{12}$ Franklin Pierce Inaugural Address, 4 March 1853, reprinted in Franklin Pierce, 1804-1868; Chronology, Documents, Biographical Aids. Irving Sloane, ed. (Dobbs Ferry, NY: Oceana, 1968), 17-24.

${ }^{14}$ James Buchanan, J. Y. Mason and Pierre Soule,“The Ostend Manifesto,” from the House Executive Documents, 33 Cong., 2 Sess., Vol. X, 93, http://xroads.virginia.edu/ hyper/hns/ostend/ostend.html (accessed 20 March 2003). 
Spain refused to sell Cuba . . . the United States should take it."15 The Cuba question was even featured in the Lincoln-Douglas debates on 15 January 1858 in Jonesboro, Illinois, when the ardent expansionist Douglas warned that U.S. "interests would be advanced by the acquisition of the island of Cuba" and "the people [will] decide the question of slavery for themselves.” This statement was followed by terrific applause from the crowd. ${ }^{16}$ The following year, in a speech before the U.S. Senate, James Dixon of Connecticut formally articulated a long-standing aspiration for some in the United States that "territorial acquisition [of Cuba] and America's sense of democratic mission were one."17

The U.S. Civil War refocused issues of annexation and slavery away from Cuba, but they resumed soon after the armistice. The outbreak of the Ten Years War (1868-1878) in Cuba threatened U.S. interests and grabbed international attention. In his "Second Message to Congress,” on 5 December 1870, President Ulysses S. Grant referring to the insurrection that had erupted on the island (and which would last another 8 years) noted the "unhappy condition of Cuba" and called for an end to the "exterminating conflict"

${ }^{15}$ Scott Nearing, “The Beginnings of World Dominion," in The American Empire (New York: Rand School of Social Science, 1921), 60-73.

16 “Third Debate with Stephen A. Douglas at Jonesboro, Illinois, 15 September 1858” in Harold Holzer, The Lincoln-Douglas Debates: The First Complete Unexpurgated Text (New York: Harper Collins, 1993), 154.

${ }^{17}$ James Dixon, "Speech of the Hon. James Dixon of Connecticut, on the thirty million bill, for the acquisition of Cuba. Delivered before the Senate of the United States, 25 February 1859,” (Washington: L. Towers, 1859). 
that engulfed the island. ${ }^{18}$ What means would be required in achieving that end were not enumerated.

By the close of the century, with the war of independence from Spain continuing to destroy U.S. holdings on the island, President McKinley in 1898 made one last attempt to purchase Cuba from Spain as a way to avoid entering the conflict over sovereignty that had once again engulfed the island; the offer of $\$ 300$ million was turned down by the Spanish crown. Later that year, when the United States engaged Spain in a rancorous war and quickly overpowered Spanish forces and claimed U.S. victory, thirty years of revolutionary rebellion against the Spanish Crown by the Cuban people abruptly ended. Although characterized by President Mc Kinley in an announcement to Congress on 11 April 1898 “as a neutral stop to war,” many thought that in reality, intervention measures established U.S. claim to the island by virtue of arms. ${ }^{19}$

U.S. participation in the war of 1898 was as much debated in Washington as in Madrid or Havana. In the end, however, public sentiment and political opportunism prevailed. Some U.S. observers pointed to the lackluster military operations of the Cubans in their independence struggles as indicative of the irresolute Cuban character and as a rationalization for engaging in the war. Others hailed the Cubans as patriots. For example, after being nominated as the Democratic candidate for the U.S. presidency in

${ }^{18}$ Ulysses S. Grant, Second State of the Union Address, 5 December 1876; State of the Union Address 1793-2011, http://stateoftheunionaddress.org/category/ulysses-sgrant (accessed 27 July 2010).

${ }^{19}$ William McKinley quoted in Louis A. Pérez, Cuba: Between Reform and Revolution. (New York: Oxford University Press, 1995), 178. 
1900, William Jennings Bryan noted in his acceptance speech that "when the President, supported by a practically unanimous vote of the House and Senate, entered upon a war with Spain for the purpose of aiding the struggling patriots of Cuba, the country, without regard to party, applauded."20

Figure 3

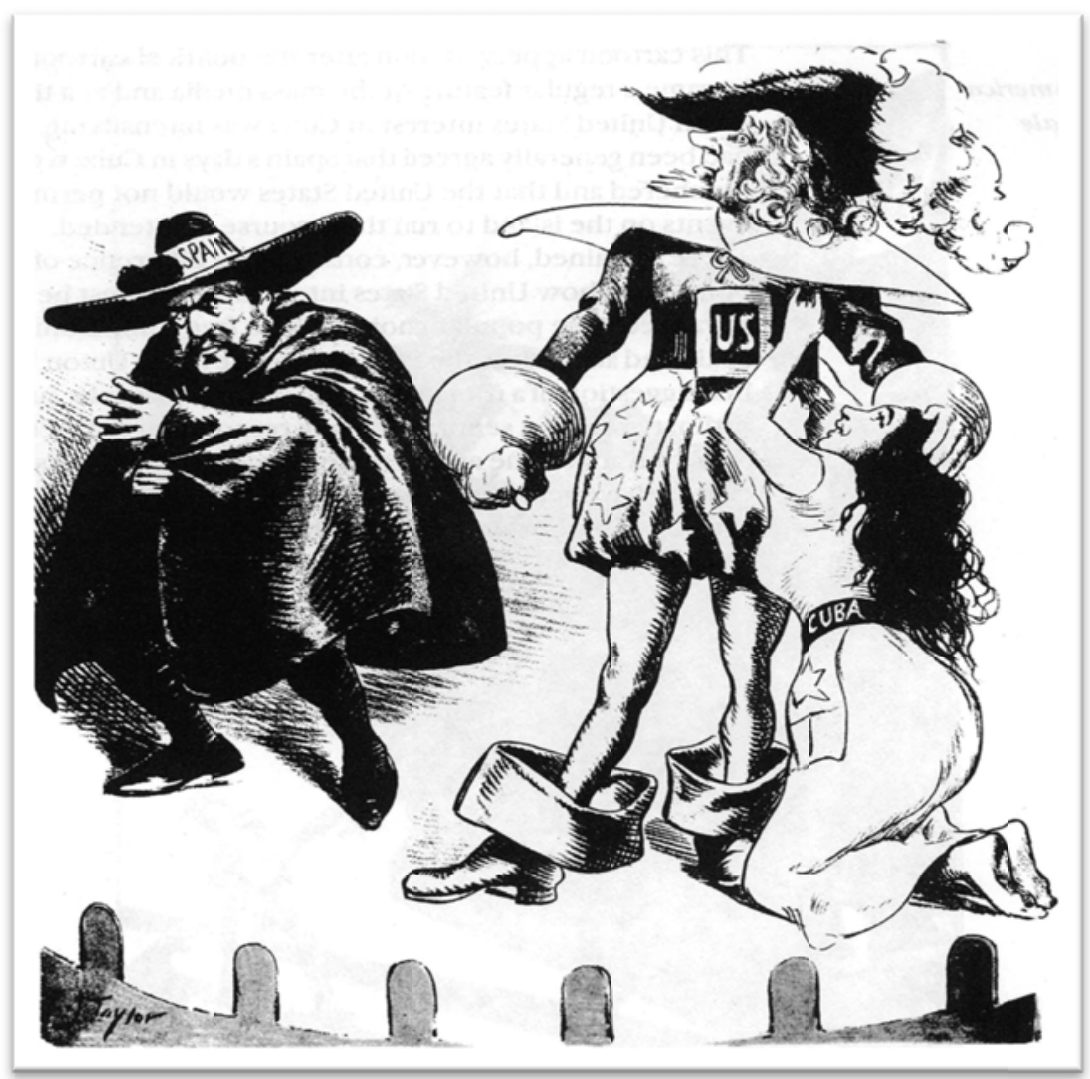

Protector of Freedom

J. Taylor, 1898

Source:

http://www.uncg.edu/ jwjones/world/visualtours/cubacartoons/cubacartoon10.html

${ }^{20}$ William Jennings Bryan, "Imperialism," in Under Other Flags: Travels, Lectures, Speeches (Lincoln, NE: Woodruff-Collins Printing Co., 1904); speech delivered by Bryan in response to the Committee appointed to notify him of his nomination to the presidency, at Indianapolis, 8 August 1900. 
With Spain's declaration of war on the United States, Cubans were denied recognition as belligerents and summarily excluded from the peace talks while the U.S. negotiated a unilateral peace at the war's conclusion. ${ }^{21}$ In addition, claiming to have ended Spain's colonial rule over Cuba, the United States established a neo-colonial protectorate -a different kind of patronato — and asserted its own right to govern Cubans. After 400 years of Spain's colonial rule, and a century of attempted machinations to purchase or annex Cuba, official U.S. occupation of the island began on 1 January $1899 .{ }^{22}$ Autonomista aspirations summarily evaporated; for the new Cuban "citizens," "Por el bien de Cuba" (for the good of Cuba) became the compelling force of both independentistas as well as for those favoring continued U.S. control.

\section{Urban Landscape}

The national drama of occupation and emerging national identity played out, in large part, on the narrow streets of the neo-republican capital and Havana, "la patria pequeña," was often described as a microcosm of the whole island. Sugar had proved a boon to Cuba during the nineteenth century and provided economic prosperity for a new elite group who built impressive homes in the capital while administering their estates in the provinces as absentee owners. Nevertheless, the Havana that greeted the U.S. occupation delegation was seen as less than its traditional description as the "pearl" of the Antilles. It was noted that “while Havana was touted as the 'emporium of Central America,' its

${ }^{21}$ Michael H. Hunt, Ideology and U.S. Foreign Policy (New Haven, CT: Yale University Press, 1987), 61-62.

22 Pérez, Cuba: Between Reform and Revolution, 178. 
visage was less than appealing.”23 In addition, Cuba’s aspiration to fully identify as a part of the "modern world" (U.S. and Western Europe) remained an exercise in ambivalence, somewhat bolstered by the U.S. presence, but proved to be unattainable hindered as it was by continued identification with Central America and the rest of Latin America.

Wars devastated the countryside and taxed Havana's ability to sustain the displaced population in a city that was plagued by inadequate infrastructure and facilities. For example, in the late 1870s, Antonio Carlo Gallenga, an Italian politician and London Times reporter sent on assignment to Cuba to assess the "rebellion,” described the capital city as both a tropical paradise and a "city of smells and noises." Arriving by ship into Havana harbor a visitor disembarked into Old Havana, a section Gallenga described as composed of narrow, crowded streets "flanked on either side by fetid gutters, paved with the hardest and most uneven stones, with raised footpaths barely ten inches wide ...” The cathedral of the colonial capital was quite large, but less than grand; it appeared "old, yet not ancient, [and quite] dilapidated ... its ugliness scarcely redeemed by the so-called 'mausoleum of Columbus'” it enshrined. ${ }^{24}$

The newer sections of the city, accessible through wide swaths cut into the colonial walls, were described as a "maze of streets . . . all unfinished, [and] many impassable.” 25

\footnotetext{
${ }^{23}$ Antonio Gallenga, Cuba: The Pearl of the Antilles (London: Chapman Hall, 1883), 11.

${ }^{24}$ Ibid., 25-26, 29.

${ }^{25}$ Ibid., 7.
} 
Although Spanish officials tore down sections of the old colonial city walls in 1853, it was a republican Cuba that completed the job in the early twentieth century in an effort to show the world its commitment to modernity. ${ }^{26}$ From its earliest history as a port of call, Havana seemed to be in a perpetual state of transition that wars transformed into near chaos. In the suburbs, by contrast, villas and cottages were rich in marble and building facades covered in Genoan marble seemed more common than those made of lumber. In these areas, the residents were mostly foreign-born, with American, German, and British on the "inside" of the nicer houses, and "Gallegos and Negroes" on the outside. ${ }^{27}$

Displaced from their provincial homes by rebel uprisings and Spanish retaliation, large numbers of Cubans sought refuge in the urban centers during the second half of the nineteenth century. Cosme de la Torriente, self-proclaimed Cuban "freedom fighter and patriot” of the Ten Years War (1868-1878), remembered the displacement when rebels, led by General Henry Reeves (El Inglesito), burned the family ingenio in Matanzas. ${ }^{28} \mathrm{He}$

${ }^{26}$ Manuel Fernández Santalices, Las Calles de la Habana entramuros: arte, historia y tradiciones en las alles y plazas de la Habana vieja (Miami: Saeta Ediciones, 1989), 26.

${ }^{27}$ Gallenga, Cuba: The Pearl of the Antilles, 30-31. For a description of the transformation of the suburbs toward El Cerro, southwest of Havana walls, during the nineteenth century, see Luis Martínez Fernández, Fighting Slavery in the Caribbean: The Life and Times of a British Family in Nineteenth-Century Havana (Armonk, NY: M.E. Sharpe, 1998).

${ }^{28}$ U.S. born Henry Reeve (1850 - 1876) was a Brigadier General in Cuba's 'Ejército Libertador' during the Ten Years' War (1868-1878) and served under the command of Máximo Gómez; Pedro Gracia y Ramón Barreras, "Brigadier Henry Reeve: El joven legionario de la libertad” Granma (Cuba), 4 August 2001, http://www.latinamericanstudies.org/cuba/henry-reeve.htm (accessed 4 July 2010). 
wrote of the family’s move to the capital and of finding life in the city to be chaotic. ${ }^{29}$ The Yarini’s extended family in Matanzas likely also underwent similar economic displacement as a result of the successive rebellions that erupted on the island beginning in 1868.

Three decades later, as a result of the fighting during the final war for independence (1895-1898), Havana — which was somewhat removed from the eastern fighting and pillaging of both Spanish regulars and Cuban rebels_-beckoned the displaced with opportunities for employment and safety. By the end of the war in 1898, a shanty-town of more than 100,000 emerged in the outskirts of the city. Blighted by disease, governed by occupation forces, and bloated with immigrants seeking to "make America" - much as José Leopoldo had done a century earlier — the bustle of the city was accompanied by the cacophonous clatter of railroad bells, roaring engines, and of myriad public conveyances. Ferries, trains, steamers, mail boats, and the constant "traffic racket joined the neverending peel of church bells, [some] 6000 victorias, tram cars, omnibuses, heavy wagons, the Babel of voices, the twang of guitars, squeak of fiddles, and the morning gun from the guard ship at daybreak.”30 To this was added the hawking of street vendors and those selling the nearly sixty periodicals that were regularly published in the city—some, like

${ }^{29}$ Cosme de la Torriente, Cuarenta Años de mi Vida: 1898-1938 (Havana: A. Muniz, 1939), xxiv.

${ }^{30}$ Gallenga, Cuba: The Pearl of the Antilles, 35. Popular during the late nineteenth-century, victorias were four-wheeled carriages that carried two passengers. Each had a high seat in front for the coachman; for a short time the term was adopted to describe early automobiles. 
the Diario de la Marina, twice each day. ${ }^{31}$ The rattle was heightened by the lack of vegetation, the "low houses, [and the] elastic air.”32 "Bald-headed money,” Spanish coins stamped with the face of King Alfonso, circulated freely, along with francs, liras, dollars, and pesos. ${ }^{33}$ Caught in a time-warp of sorts, the sights and sounds of the city changed little in the ensuing decades, and guidebooks of the 1910s and 1920s, were remarkable in the descriptions of an almost unchanged urban landscape. ${ }^{34}$

The city U.S. troops entered and occupied in 1898 also was crippled under the specter of famine and disease. Occupation General John Brooke moved vigorously to implement health reforms immediately and in 1899 assigned Major William Crawford Gorgas to effect a "permanent betterment of public health.”35 Much as José Leopoldo had written in 1833, prevailing medical thought and popular fears that were still largely based on the

${ }^{31}$ Directorio Comercial y Oficial de Cuba, Puerto Rico, y las demas Antillas, inclusas las Bermudas para el ano 1901 ( New York: The Spanish American Directories Company, 1901).

${ }^{32}$ Gallenga, Cuba: The Pearl of the Antilles, 31, 35.

${ }^{33}$ In Alberto Yarini's pockets at the time of his death, along with Cuban and French coins the police found \$5 in Spanish silver, and a \$20 U.S. gold piece; ANC, Audiencia de la Habana, Legajo 643/3, Folio 247-248.

${ }^{34}$ For various contemporary descriptions of Havana and its environs, see Albert J. Norton, Norton's Complete Handbook of Havana and Cuba (Chicago: Rand McNally, 1900); T. Philip Terry, Terry's Guide to Cuba, (Boston: Houghton Mifflin, 1927); and A. Hyatt Verrill, Cuba of Today, (New York: Dodd, Mead and Company, 1931).

${ }^{35}$ Bradley, Havana: Cinderella’s City, 386. For a description of sanitation efforts to rid Havana of yellow fever and a discussion of how endemic outbreaks in the city influenced power relationships between Cuba and the U.S., see Espinosa, Epidemic Invasions; and Mariola Espinosa, "A Fever For Empire: U.S. Disease Eradication in Cuba As Colonial Public Health,” in Alfred W. McCoy and Francisco Scarano, ed., Colonial Crucible: Empire in the Making of the Modern U.S. State (Madison: University of Wisconsin Press, 2009). 
miasma theory of diseases that considered poisonous vapor or mist filled with particles from decomposed matter as the cause of illness such as yellow fever and cholera, fueled Gorgas efforts to sanitize the city. ${ }^{36}$ Through his successful and dramatic work in eventually quelling disease-induced mortality in Havana, Gorgas acquired an international reputation as a sanitarian and his services became sought after throughout the Caribbean basin.

“Cuba’s Ally,” a political cartoon published in 1895, implied that yellow fever was probably the best "strategy" the Cuban rebels marshaled in their independence struggle. (See Figure 4$)^{37}$ During the independence War, the annual onset of "black vomit" (yellow fever) was sometimes viewed as perhaps one of Cuba's strongest weapons against the Spanish by political cartoonists in the U.S.

${ }^{36}$ Retired as Major General in October, 1918, Gorgas became famous for his handling of yellow fever in the Panama Canal region.

${ }^{37}$ See Francis Gilbert Attwood, Attwood's Pictures: An Artist's History of the Last Ten Years of the Nineteenth Century (New York: Life Publishing, 1900), August 1895, no page numbers. 
With this incentive, Havana was meticulously sanitized with "house to house cleaning and careful supervision of drainage and general sanitation” conducted by U.S. occupation troops, the sick were segregated, and neighborhoods quarantined. ${ }^{38}$ "Streets almost impassible by the accumulation of garbage were cleared;" attention was given to water supplies and public sewer systems; and as an observer noted, “'chlorinated lime’ lay over the tropical city like a freak fall of snow, the blight of pestilence that had endangered

${ }^{38}$ Gorgas to Adjutant General, Havana, 8 May 1900, Department of Havana, Report of Major William Crawford Gorgas, Chief Sanitary Officer of the City of Havana, Havana, 28 November 1900. 
troops and visitors alike was largely abated. ${ }^{39}$ Immediately after the war, however, the disease persisted despite the aggressive sanitation efforts which mistakenly targeted the disease by fumigating everything with "noisome fumes." In 1900, a "black vomit" epidemic descended upon Havana with chances of death four to one against any person contracting the disease. Gorgas was aware of the pioneering work of Cuban doctor Carlos J. Finlay, but put little stock in his theories of how yellow fever was transmitted. ${ }^{40}$ As early as 1881, Finlay specified the Aedes aegypti mosquito as the vector for yellow fever. With the outbreak of a major yellow fever epidemic in 1900, U.S. Army Major Walter Reed led a team (later named the "Reed Commission") to identify and isolate the yellow fever virus. Much of the team's work was done at facilities near Havana, using the foundational work of Finlay. It was not until the "discovery" of the role of mosquitoes in the spread of the disease that yellow fever was finally controlled in Havana and elsewhere in the Caribbean basin and in other tropical regions as far away as Hawaii. ${ }^{41}$ In a letter to Reed in February 1906, in a condescending choice of words for anything Cuban, Gorgas gave full credit for the discovery to Reed's work and asked the

${ }^{39}$ Hudson Strode, The Pageant of Cuba, in Bradley, Havana: Cinderella’s City, 387.

${ }^{40}$ Dr. Carlos Finlay (1833-1915), Cuban born son of a Scotch physician, educated at the Jefferson Medical College in Philadelphia. His early work on yellow fever was published in 1881, Carlos J. Finlay, "El mosquito hipotéticamente considerado como agente de transmisión de la fiebre amarilla." Anales de la Real Academia de Ciencias Médicas Físicas y Naturales de la Habana 18 (1881) reprinted in Medical Classics 2 (February, 1938), 147-169.

${ }^{41}$ James Carroll, Aristides Agramonte, and Jesse Lazear were Reed's assistants, but Finlay was not allowed to participate. Logan Clendening, Source Book of Medical History (Mineola, NY: Dover Publishing 1960; Toronto: General Publishing, 1942), 465, 483. 
Major to make allowances for "old” Doctor Finlay: "I acknowledge that the less that is said about [Finlay's] experiments to prove his theory, the better for the old Doctor's reputation as a scientist. But he reasoned it out and believed it and stuck to it for 20 years; You are the great man in the matter ... your name will be remembered in medicine with Jenner and Wills long after the old doctor has been forgotten so do not begrudge the old man his little need of praise.”42 Like their participation in their own independence, Cuban participation in the "betterment" of public health was discredited by U.S. authorities.

Within a year U.S. authorities claimed that no world capital surpassed Havana for cleanliness; the city that was notorious as a seasonal port of pestilence, moved to an enviable health record in a short time. The effect was long-lasting and between 1905 to 1909 a mere of 345 cases of yellow fever were reported for all of Cuba, where formerly they had numbered in the thousands, and in April 1910 the U.S. declared the island to be entirely free from the disease. In spite of the Reed Commission's report on the causes of yellow fever fumigation tents erected by U.S. health officials, in 1899 continued to dot the city for most of the first decade of the twentieth century. ${ }^{43}$

${ }^{42}$ Letter from William Crawford Gorgas to Walter Reed, 6 February 1902, The Philip S. Hench Walter Reed/Yellow Fever Collection [manuscript] / [collected by] Philip S. Hench (Charlotsville, VA.: University of Virginia, Health Sciences Library), accession number: 02604.

${ }^{43}$ In 1897, Havana reported 603 deaths from yellow fever between April and August; by 1901 Gorgas reported only 3 deaths during those months (down from 89 in 1900). W. C. Gorgas, "The Results of Yellow Fever Sanitation in Havana, Cuba, for the year 1901 up to September first, carried on upon the basis that the stegomyia mosquito is the sole means of transmission," Public Health Papers and Reports, 1901: 27,130-133. With U.S. focus on disease prevention and constant fumigation of streets, homes and 
TABLE 2

\begin{tabular}{|l|l|l|l|}
\hline \multicolumn{5}{|c|}{ International Death Rate per Thousand (1910) } \\
\hline Country & \multicolumn{1}{|c|}{ Percent } & \multicolumn{1}{c|}{ Country } & Percent \\
\hline Australia & 12.60 & Germany & 17.80 \\
\hline CUBA & 12.69 & Scotland & 18.00 \\
\hline Uruguay & 13.40 & Switzerland & 18.20 \\
\hline United States & 15.00 & Venezuela & 18.90 \\
\hline Belgium & 15.20 & France & 20.60 \\
\hline Norway & 15.60 & Japan & 20.80 \\
\hline Sweden & 16.10 & Austria & 24.40 \\
\hline Denmark & 16.40 & Italy & 29.20 \\
\hline Holland & 17.40 & Spain & 29.70 \\
\hline England & 17.70 & & \\
\hline
\end{tabular}

Source: León J. Canova, Cuba: A Pamphlet Descriptive of the Island of Cuba containing Unembellished Data for General Information, 1910

individuals, by 1909, Cuba boasted one of the lowest death rates in the world, surpassed only by Australia; a decrease of $165 \%$ in less than 10 years. See Canova, Cuba: A Pamphlet Descriptive of the Island of Cuba containing Unembellished Data for General Information, (Havana: n.p., 1910), 8, 65. See Table 3: International Death Rate per Thousand, 1910: 
Another U.S. military physician, Leonard Wood, served as Military Governor of Cuba (1899-1902) after participating in the conflict of 1898. He, too, was intent on cleansing the city and improving conditions. Governing with an iron hand, Wood's harsh and unpopular measures were seen as especially oppressive and the criollo population bristled as foreign imposed regulations multiplied and increasingly limited their soverignty. The unrest in Havana grew after the Platt Amendment, which provided for formal U.S. involvement in Cuban affairs and established U.S. claims to economic and military territories in Cuba, was approved by the U.S. Congress as part of the Army Appropriations Act on 1 March 1901. The next day, it was reported that more than 15,000 of Havana's citizens joined a torchlight procession through the city protesting the amendment. Demonstrations and meetings continued to stir popular unrest throughout March of that year. In his memoirs, Sixty Years in Cuba, Edwin Atkins recorded that fights on Havana streets frequently resulted in serious injuries and deaths among Cubans and U.S. troops. ${ }^{44}$ By April of that year the war of words intensified. On Good Friday, 5 April 1901, after the publication of a political cartoon highly critical of U.S. actions in $L a$ Discusión, one of Havana’s dailies, both the editor, Manuel Coronado, and the cartoonist, Jesús Castellanos, were arrested and jailed. ${ }^{45}$

${ }^{44}$ Atkins, Sixty Years in Cuba, 303. For a discussion of politics and society in Cuba, see Louis A. Perez, Jr., Cuba Under the Platt Amendment, 1902-1934 (Pittsburgh: University of Pittsburgh, 1986/1991).

${ }^{45}$ La Discusión was founded in 1878 by Adolfo Marquez Sterling and purchased by Manuel Coronado in 1895. The paper was a strong proponent of independence and was shut down by Spain's General Valeriano Weyler in 1896 . Undeterred, Coronado returned to Havana in 1897 and resumed publication of the daily. 
The controversial cartoon was entitled, "The Cuban Calvary." ${ }^{46}$ It depicted the "Cuban People," represented by Christ on the cross, between two thieves: General Wood and U.S. President William McKinley. Mary Magdalene, representing Cuban public opinion, was shown on her knees crying at the foot of the cross and a Roman soldier carrying a spear with "The Platt Amendment” written on it was clearly meant to be Connecticut Republican Senator Orville H. Platt. The caption read: "Destiny does not deserve a glorious resurrection for us.” Large sectors of the Cuban people were bitterly opposed to the imposition of the Platt patronato which stipulated the conditions for U.S. withdrawal from Cuba, ensured continued involvement of the U.S. in Cuban foreign and domestic affairs—including terms for the franchise-and guaranteed U.S. control of certain military and economic holdings on the island. ${ }^{47}$ Angered by the cartoonist's depictions, Governor Wood charged and arrested the men for criminal libel and held them at the Vivac, the civilian prison in the city. In addition, Wood had the offices of La Discusión boarded up. The two men were released the following day, and on 8 April La Discusión resumed operation with the defiant headline "Suppressed by Weyler, October 23, 1896; Suspended by Wood, April 6, 1901." The U.S. press bitterly condemned Wood's closure

${ }^{46}$ For a contemporary description of the cartoon, see "The Freedom of the Press," Public Opinion, Thursday, 18 April 1901, 488. See also Leopoldo Fornes Bonavia, Cuba, cronología: cinco siglos de historia, política y cultura (Madrid: Editorial Verbum, 2003). Compare with Joan Casanovas, Bread and Bullets which cites the dissolution of the daily in 1882, 145. See also Virgilio Companioni Albriza, "La oposición a la Enmienda Platt en la caricatura política de la época (1899-1902), (http://www.monografias.com/trabajos55/oposicion-enmienda-platt/oposicion-enmiendaplatt.shtml) accessed 20 August 2010.

${ }^{47}$ For a discussion on U.S. immigration and economic interests in Cuba and U.S. annexationist sentiment in the early $20^{\text {th }}$ century, see Carmen Diana Deere, "Here Come the Yankees! The Rise and Decline of United States Colonies in Cuba, 1898-1930," Hispanic American Historical Review 78, no. 4 (Nov, 1998): 729-765. 
of the paper citing freedom of the press as a foundational tenet of the North American model of government; it condemned Wood for using the "Spanish rather than the American method of dealing with a blasphemous and insolent newspaper." ${ }^{48}$ After several more months of sometimes-violent protests and demonstrations by the citizenry, the delegates of the Constitutional Convention convened in Havana acquiesced to U.S. demands and by a single vote the Platt Amendment became a part of the Cuban Constitution of $1901 .{ }^{49}$ The Amendment, while guaranteeing an end to the occupation, imposed U.S. controls on the Cuban self-government, especially in the area of foreign relations and debt restrictions (and would prove be a political fetter for Cuban self-rule until 1934). ${ }^{50}$ After the military occupation ended in 1902, Tomás Estrada Palma, a U.S. citizen who had lived in New York for 25 years, regarded as an "ultraconservative" and a U.S. ally, became the first President of the republic. That same year, Wood left Havana for the Philippines and a promotion.

During Wood's short tenure, U.S. occupation forces also worked on beautification projects of the Prado Promenade that crossed the city's center and began construction of the first section of the Malecón, the broad esplanade and seawall that runs westward along the coast from the mouth of Havana Harbor in Old Havana. After two subsequent

48 "The Freedom of the Press," 488.

${ }^{49}$ Simmons, Cuba: From Conquistador to Castro, 208-214.

${ }^{50}$ News of the adoption of the Platt Amendment sparked anti-U.S. demonstrations and on 2 March 1901, a torchlight demonstration descended on General Wood's house. The Cuban people were in an uproar and jammed telegraph lines with protests from across the island. Officials in Washington countered that there would be no compromise or concession to Cuban independence unless the Amendment was accepted. Ibid., 211; and Hunt, Ideology and U.S. Foreign Policy, 62. 
expansions, the avenue eventually extended northwest to the El Vedado district which was built in 1892 and was the favorite residential neighborhood for Havana's elite. ${ }^{51}$ Not coincidentally, the most extensive improvements and building projects were undertaken in those sectors that tourists and businessmen traveling to Havana-many from the U.S.- encountered upon disembarking from the many steamers that traveled to Havana. Wood also overhauled the justice system including the police, the courts and jails. He initiated a public school system modeled on that of Ohio, and launched sweeping reforms at the University of Havana including curriculum reform and engineered its relocation from the old Dominican Convent to its current location in El Vedado. The University was a jewel in the ravaged city and boasted an impressive medical school and faculty that included Finlay (ophthalmology), Jose Yarini (biology) and Cirilo Yarini (oral surgery) which Wood left intact. ${ }^{52}$ No doubt the young Alberto Yarini grew up surrounded by academicians, Havana's most noted doctors, and the elite that made their home in the El El Vedado district. Over family meals the Yarinis, and their colleagues at the university, including Finlay, must have had many discussions about the course of events in Havana.

With the capital's population swelling to nearly a quarter of a million, in the immediate aftermath of the war, U.S. occupation forces orchestrated massive feedings for up to

${ }^{51}$ Marial Iglesias Utset, "Imágenes en Conflicto: Cuba y la presencia imperial norteamericana (1898-1902), in Lorini, An Intimate and Contested Relation, 38-39.

52 Juan M. Dihigo, “La Universidad de la Habana: bosquejo histórico,” (Havana: Imprenta “El Siglo XX”, 1916), 160, 165. 
20,000 each day. ${ }^{53}$ The "spectacle" was not lost on the U.S. popular press that turned its support from demanding U.S. intervention in 1898 to berating the expenditures brought on by occupation. Political cartoons of the era clearly show the dramatic change in U.S. popular opinion of the island nation. For example, cartoons such as Thomas May's depiction of Cuban army regulars, "This Style of Plaster Will Cure All their Wounds," depicted Uncle Sam “bandaging” barefoot, ape-like Cuban soldiers with U.S. dollars. ${ }^{54}$

The U.S. yellow press found much material on the Cuban condition in the transition from Spanish rule to U.S. protectorate. Cartoon images published between 1896 and 1906 constitute a record of shifts in U.S. foreign policy and popular opinion. ${ }^{55}$ Pre-1898 cartoon images of Cuba romanticized the colonial experience by showing Cuba as a damsel in distress, a noble savage, and even as Eugène Delacroix’s La Liberté56. In the years immediately after 1898, however, the damsel image gave way to simianized depictions of Cuba as the object of ridicule and disdain. By the close of the first decade of the twentieth century, the feminized and simianized—but adult—depictions of Cubans,

53 The population of the city of Havana was recorded as 235,981 in the1899 Census of Cuba, United States Department of War. Report on the Census of Cuba, 1899. Washington, D.C.: Government Printing Office, 1900, 47.

54 Thomas May, “This Style of Plaster Will Cure All their Wounds,” Detroit Journal, 1899, in John J. Johnson, Latin America in Caricature (Austin: University of Texas Press, 1980).

${ }^{55}$ For discussion on the role of political cartoon and popular opinion in U.S.Cuba relations see Benjamin, The United States and the Origins of the Cuban Revolution; Johnson, Latin America in Caricature; and Adelaida de Juan, Caricatura en la República (Havana, Editorial Letras Cubanas, 1982).

${ }^{56}$ Liberty leading the People (La Liberté guidant le peuple), by Eugène Delacroix was painted in 1830, to commemorate France's July Revolution of 1830 that deposed the Bourbon King Charles X and enthroned the “citizen king” Louis-Philippe. 
were replaced in the U.S. popular press by laughable and stereotypical children which ultimately deteriorated into images of Cubans as pickanninies, highlighting Cuba’s “independence” as subordinate and inferior in the hierarchy of nations. This last permutation gained general acceptance after the second U.S. occupation (1906-1909). If, as has been argued, it is not in official rhetoric that one can gauge public opinion, then popular culture—-such as political cartoons—-may best speak for and to a people. ${ }^{57}$ Cubans were not immune to the ridicule and the sub-human depictions of their struggles for self-governance and public disaffection with all things U.S. continued to mount.

The U.S. press characterizations, however, were not without their base in actual events. Before 1898, one observer noted that "the real bane of social life in Havana lies in the deep-seated and hardly-smothered animosity of race.”58 By 1910, however, Irene Wright recoiled commenting that the "decadence and depravity in Cuba was due, largely, to the too free commingling of black blood and white.” In the analysis of the 1899 census, census takers argued that the decline of Cuba's black population at the close of the century was reflective of the race's inferiority and drew parallels to a similar phenomenon in the U.S. Hugh Thomas has argued that the "undeniable racism of AngloSaxon Americans was evident” in all sectors of the city. ${ }^{59}$ That racism extended well beyond U.S. citizenry in Havana.

${ }^{57}$ Mayra Beers and Roberto Pacheco, "Damsels, Apes and Pickanninies” (unpublished manuscript), 12.

58 Thomas, Cuba: Or the Pursuit of Freedom, 418 - 419.

${ }^{59}$ Gallenga, Cuba: The Pearl of the Antilles, 39. 
Following independence ambivalent attitudes toward race divided Cuban nationalists as they sought to create a united polity. Complicating the issue, adherents to the emerging pseudo-science of eugenics added a new vocabulary to the debate. Coined in the late nineteenth century, eugenics advocated "race improvement" through scientific and social selective human breeding and had many adherents in the U.S. and Northern Europe. U.S. citizens broadly embraced eugenics as a "modern" and scientific path to address racial confusion and the influence of eugenist thought influenced the Cuban republic's social and legal evolution. Early eugenists equated racial differences and physical proportions to mental and moral capacities that limited or enhanced participation in socio-political processes. Perhaps the most well-known example of eugenist rationale for Cuba was the publication in 1900 of Maceo's Skull: an Anthropological Study (El cáaneo de Maceo: studio antropológico) which detailed the scientific measurement of Maceo’s skull to show that he possessed the unique combination of a "white" brain and a "black" body and was thus the embodiment of a "super"man. Law, science and the social sciences had an important role in defining categories of citizenry in the early republic as scientists and jurists tried to provide means for a break with the labels of a colonial past with a new scientific approach.. During subsequent decades, black and mulatto intellectuals such as Nicolas Guillén used the writings of social scientists such as Fernando Ortíz and Israel Castellanos to counter the rising disparity of nationhood based on race with little success. Legal developments which had created opportunity for Afro-Cubans in the post independence republic had also been the source of repression and exclusion manifested in lack of opportunity and disenfranchisement. ${ }^{60}$

${ }^{60}$ For a discussion of the role of social scientists and jurists in the development of 
In the aftermath of war and with the promise of "equality" rural Afro-Cubans had settled in large numbers in Havana. Although not enough to elect their own national candidate, in 1901, Afro-Cubans (black and mulatto) made up 32\% of voters on the island, most of them living in urban areas, and should have commanded a measure of importance for politicians. ${ }^{61}$ Like their white counterparts, after the war, Afro-Cubans demanded government jobs and expanded economic opportunities. In 1907, however, the census reported that of 205 national government employees, still only 11 were Afro-Cubans. ${ }^{62}$

Adding fuel to the posivist eugenics debate of the perils of diluting racial purity, large numbers of foreigners were added to the displaced and largely destitute citizenry that moved into the congested capital city. The report from the U.S. Board of Health indicated that three-fourths of the city's population lived "in the most densely populated localities in the world;” the city's geography covered a smaller area than any other city in

a racial discourse for national polity in Cuba and the rise of eugenics in nationalist discourse through the 1930s, see Bronfman, Measures of Equality; Alessandra Lorini, "Social Scientists Wrestling with Race and Nation: A Transnational Perspective on African-American W.E.B. Du Bois and Cuban Fernando Ortiz,” in Alessandra Lorini, ed, An Intimate and Contested Relation: The United States and Cuba in the Late Nineteenth and Early Twentieth Centuries (Florence: Firenze University Press, 2005), 97-123. See also Alessandra Lorini, Rituals of Race: American Public Culture and the Search for Racial Democracy (Charlottsville: University of Virginia Press, 1999) and Daniel T. Rodgers, Atlantic Crossings: Social Politics in a Progressive Age (Cambridge: Belknap Press, 1998). For a discussion of the role of role of science in addressing the problems of race, gender, reproduction, and public health in Latin America, see Nancy Leys Stepan, The Hour of Eugenics: Race, Gender, and Nation in Latin America (Ithaca, NY: Cornell University Press, 1991). For a general account of racial thought in Cuba, see Aline Helg, "Race in Argentina and Cuba, 1880-1930," in Richard Graham, ed., The Idea of Race in Latin America, 1870-1940 (Cambridge: Cambridge University Press, 1990), 37-69.

${ }^{61}$ U.S. Dept. of War, Report on the Census of Cuba,1899, 148.

${ }^{62}$ U.S. Dept. of War, Report on the Census of Cuba, 1907. Washington, D.C.: Government Printing Office, 1908, 256. The Census reported similar proportions in other sectors except the military where Afro-Cuban participation was considerably higher. 
Europe or the Americas with similar population figures. ${ }^{63}$ With the population of Havana province approaching half a million, its inhabitants represented more than a quarter of the island's total population of some 1.6 million. Havana City alone was home to almost $15 \%$ of the island's inhabitants. Within two years of the peace in 1898, an additional 25,000 immigrants entered Havana, further swelling the city’s population and by 1907 adding to the natural population increase, improvements in health measures, and the influx of inhabitants from rural areas, more than 120,000 white immigrants arrived in Cuba, with large numbers choosing to stay in the already overburdened capital city. (See Table 3: Cuba’s Population 1887-1953.)

Table 3

\begin{tabular}{|c|l|l|l|l|l|l|}
\hline \multicolumn{7}{|c|}{ Cuba's Population: 1887-1953 } \\
\hline Year & \multicolumn{1}{|c|}{ Cuba } & $\begin{array}{c}\text { Havana } \\
\text { City }\end{array}$ & \% & Male & Female & $\begin{array}{l}\text { Foreign } \\
\text { White }\end{array}$ \\
\hline 1887 & $1,631,687$ & & & & & \\
\hline 1899 & $\begin{array}{l}1,572,797 \\
\text { net loss of } \\
3 \%\end{array}$ & 235,981 & 15.0 & 815,205 & 757,592 & 142,098 \\
\hline 1907 & $\begin{array}{l}2,048,980 \\
\text { net increase } \\
37.8 \%\end{array}$ & 290,065 & 14.8 & n/a & n/a & 268,352 \\
\hline 1919 & $2,889,004$ & 363,506 & 12.6 & $1,530,509$ & $1,358,405$ & 535,950 \\
\hline 1953 & $5,829,029$ & $1,223,900$ & 21.0 & $2,985,155$ & $2,843,874$ & 149,327 \\
\hline
\end{tabular}

Compiled from Susan Schoeder, Cuba: A Handbook of Historical Statistics (Boston, G.K. Hall, 1982), 42, 44, 50, 52, 54, 59, and 61.

${ }^{63}$ Charles B. Reynolds, Standard Guide to Havana: A Complete Handbook for Visitors, with Maps, Illustrations, History, and an English-Spanish Manual of Conversation (Havana and New York: Foster and Reynolds Co., 1905), 98. 
Adding to the political and economic turmoil, immigrant workers from Europe (usually young, male, and single) co-opted the limited employment opportunities available. ${ }^{64}$ Competing with Cuban labor in all sectors, more than a third of all immigrants stayed in the capital city. Foreigners usurped economic opportunities in every field and male peninsulares quickly replaced Cuban women (many widows of freedom fighters) as domestics. During the U.S. occupation, for example, U.S. plumbers contracted to work in the capital organized a local union which excluded Cubans. In addition, Spanish merchants became notorious for hiring relatives from Spain (generically referred to as "nephews") rather than creoles so that the term sobrinismo came into common use on the island. ${ }^{65}$

By 1907, the city's population had increased by $25 \%$ and the percentage of foreign born residents more than doubled from $10 \%$ to nearly $25 \%$. While foreigners were swelling the population figures for the island and the city, the numbers for blacks were steadily declining from $32 \%$ in 1899 to $30 \%$ by $1907 .{ }^{66}$ More than 100,000 residents of Havana province were listed as foreign born, with Spaniards accounting for 87,000, Chinese, 3000, and U.S.-born at 1700; the rest came from more than a dozen countries. ${ }^{67}$ This foreign mostly-male influx, added to domestic displacement, and deeply affected criollas who

${ }^{64}$ Simons, Cuba: From Conquistador to Castro, 221.

${ }^{65}$ Pérez, Cuba: Between Reform and Revolution, 203.

${ }^{66}$ U.S. Dept. of War, Report on the Census of Cuba 1907, 256.

${ }^{67}$ Charles Magoon, "Reporte de la administración provisional, desde 1 diciembre de 1907 hasta el 1 de diciembre de 1908," (Havana: Rambla and Bouza, 1909), 65. According to the 1909 census, the city's population grew to 538,000; U.S. Dept. of War, Report on the Census of Cuba 1907, 256. 
already faced social restrictions and economic hardships on the island; except, perhaps, by expanding the pool of "desirable, white” husbands.

In this cultural and racial bazaar, the delighted adventurer marveled that contraband still fueled the city's economy and "there is no spot in the world like [Havana] - where money can be more easily made or more extravagantly squandered.”68 For centuries, Havana served as an intermediate harbor between Spain and its American colonies and the culture of contraband flourished. In this merchant harbor, thousands of ships docked each year smugglers collaborated with opportunists, and merchants became expert contrabandists. A report by the U.S. Department of Agriculture, Commerce, and Labor noted that Havana had more foreign shipping than any U.S. port except New York, with more than 1500 ships from some 27 different companies entering the harbor each year. ${ }^{69}$ The Yarini family traveled in and out of the city often, rubbing elbows with U.S. and European entrepreneurs, adventurers, curious tourists, poor immigrant laborers, the unemployable, and vagrants on the city's congested wharves.

\section{New Citizens}

While an ascendant bourgeoisie viewed the occupation with relief and gratitude, and many creoles, such as Cirilo Yarini, held U.S. citizenship for the tax advantages, independentismo resurfaced as the most formidable challenge to North American control and talk of eventual annexation of the island. The "better-classes," U.S. officials

\footnotetext{
${ }^{68}$ Gallenga, Cuba: The Pearl of the Antilles, 42, 47

${ }^{69}$ Canova, Cuba: A Pamphlet Descriptive of the Island, 43, 57.
} 
assumed, favored annexation and only the "rabble," who was singularly unfit to govern, demanded independence. U.S. officials hoped that over time, realizing the benefits of being a part of the United States "Empire," Cubans would "come around” and clamor for annexation. General Wood noted, "the real voice of the people of Cuba has not been heard ... when they do speak, there will be more voices for annexation than there is at present any idea of $[$ sic $] .{ }^{, 70}$ But in the elections of 1900, the Cubans did not elect the U.S.-sponsored candidates and instead opted for what occupation officials termed “demagogues” and "emotional candidates," thus proving their "inadequacy for selfgovernment. ${ }^{, 11}$ In view of the Cuban people's reluctance to submit easily to the U.S. paradigm for self-governance, by 1901 the occupation quickly became an expensive burden for the U.S. - some half a million dollars a month. Wood reported that Cubans were ungrateful for U.S. aid—noting that while they wanted independence, they were not able to manage the responsibility. Fueled by the popular press, occupation forces and many North Americans looked at Cuba with a strong sense of superiority. Wood and Gorgas, often spoke of their "charges" as stupid and irresponsible and quite unprepared for democratic endeavors. Even Estrada Palma sadly noted that "in Cuba we have a republic, but no citizens." ${ }^{72}$

\footnotetext{
${ }^{70}$ Wood quoted in Pérez, Cuba: Between Reform and Revolution, 305.

${ }^{71}$ Ibid., 181.

72 Thomas, Cuba, Or, The Pursuit of Freedom, 395.
} 


\section{Conclusion}

Independence, "rather than expressing economic interest in any one class, [. . . was] expected to open up opportunities for a heterogeneous social amalgam.”73 The movement appealed to Cubans of all classes who expected independence to create a new society. In 1902, however, “Cuba entered nationhood with its social order in complete disarray and its class structure totally skewed."74 The dominant Creole bourgeoisie of the late nineteenth century had toppled in the wake of the sugar crisis and of revolution. The economic vicissitudes of the planter elite also produced a dispossessed peasantry. In an agricultural economy, agriculture was at a virtual standstill and economic opportunities in every sector were stifled. Foreigners--including U.S. citizens with over \$200 million in investments on the island--controlled sugar production, land speculation, mining, railroads, utilities, and banking. Foreign capital funded the island's limited industry and few Cubans were willing to invest in manufacture in the absence of a viable market in the face of cheap, U.S. manufactured goods which flooded the island. ${ }^{75}$

Cuban expatriates in the U.S. were kept aware of the news as newspapers proliferated and the Associated Press carried countless accounts of the developments on the island. For the U.S., Cuba had become an expensive inconvenience tolerated because of nascent imperial aspirations and passions fueled by the rise of scientific racism. In Cuba, foreign aspirations and involvement argued against the maturation of a shared national identity.

\footnotetext{
${ }^{73}$ Pérez, Between Reform and Revolution, 213.

${ }^{74}$ Ibid., 193.

75 Ibid., 193-220.
} 
Alberto Yarini came of age during this inflection period of Cuban national development from 1898-1906. Probably living in Havana during most of this period, as a sixteen year-old in 1898, Yarini witnessed the promise of an independent Cuba stifled by U.S. occupation of the island by right of arms; in 1906, barely into adulthood as a twenty-twoyear-old, he once again saw the disintegration of his country's political system, this time through civil war and the quelling of the insurrection by a second U.S. occupation at the request of the Cuban government. This cacophony of political, economic and racial posturing had reached a fever pitch just as the twenty-four-year-old Alberto Yarini returned from his U.S. trip to Mobile in 1906, disembarked on Havana's wharves and made his way home through the San Isidro district. 


\title{
CHAPTER IV
}

“AMBITION ATTRACTED HIM TO OUR BARRIO” ":

\author{
THE SAN ISIDRO DISTRICT
}

In El Gallo de San Isidro, a play by Jose Ramón Brene written in 1964, the prostitute Elena sighs, “Alberto came tonight to San Isidro. What drives him to be mixed up with our dirty, dead, evil smelling world? Is it the boredom of a young man that has everything to make him happy? Is it the desire for easy love with no commitment? . . . Now I know it was ambition that attracted him to our barrio.”

\section{The Barrio}

Located between Habana and Egido streets, the cacophony and chaos of Havana found its richest expressions in the Barrio San Isidro. ${ }^{2}$ At first glance San Isidro had little to offer 1964), 50.

${ }^{1}$ Jose Ramón Brene, El Gallo de San Isidro, (Havana: Ediciones Revolucionarias,

${ }^{2}$ The barrio San Isidro was bounded by Acosta on the north and Habana on the south; Desamparados to the east and Egido to the west. In a city notorious for changing street names often and with little provocation, San Isidro early on was renamed Calle de las Tenazas (Street of the Forceps) because of its proximity to the gate of that name in the old city walls. Following independence, it was renamed Emilio Núñez, after a War general who later became governor of Havana. Unlike what occurred to the names of many other streets in the city, neither new name stuck; the street and the barrio are still called San Isidro. Manuel Fernández Santalices, Las calles de la Habana entramuros: arte, historia y tradiciones en las calles y plazas de la Habana vieja, (Miami: Saeta Ediciones), 24, 131-32; and Francisco Rojo García, Plano de La Habana (Havana: n.p., 1951.) 
a young aristocrat like Alberto Yarini. Named after an ancient colonial church and hospice, San Isidro was the gateway to the city. It was also home to the poor, laborers, prostitutes, and pimps. The confluence of the railroad terminals and the wharves in San Isidro that handled all seaborne traffic in and out of Havana provided a unique environment for the development of shared concepts of equality and fraternity that in many ways ran counter to the elite political discourse of modernity and nationhood of the time. At the beginning of the twentieth century, Cuban women could not vote, blacks were systematically excluded from civic participation and social mobility, and wars and immigration had left a displaced native population with little economic opportunity. In San Isidro, prostitution, religion, and gambling provided economic and social opportunities closed to the marginal sectors of society in other areas of the city. For Alberto Yarini, San Isidro was a place of economic and political opportunity; it was also far removed from his elite roots and his family's expectations for his education and position in society.

An enclave for craftsmen, bricklayers and dock workers, San Isidro was home to the city's lowest socio-economic classes. That did not preclude the residents from complaining to authorities about the government's lack of interest in policing the Barrio to safeguard gente decente (decent society) from crime and the dangers related to the prostitution trade of the wharves. The gente decente might have included the young Alberto Yarini who had decided not to continue the Yarini family tradition of pursuing a university education, but instead had set himself up in San Isidro. There he enjoyed a growing reputation as an honorable man who happened to make his living with profits 
from lottery operations and earnings from his network of foreign and domestic prostitutes who provided services for travelers lured to Havana by curiosity or economic opportunity. The unwritten social order within the San Isidro district and its attendant honor code-perhaps out of place in the world of criminality that characterized the barrio- provided an amalgam for Cubans who sought a respite from the chaos. Located on Havana's commercial waterfront, San Isidro was (and still is) a small neighborhood situated on the southeast corner of Habana Vieja where it jutted into the bay.

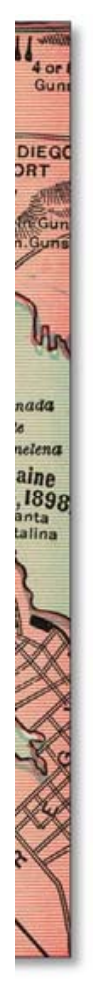

añeda 
Covering less that one square mile, the district was among the first parts of the city to be settled and its proximity to the wharves made it a perennial working class neighborhood. ${ }^{3}$ In 1898, it was home to stevedores and wharf workers, tobacco laborers and, with the new railroad station forming the barrio’s southern boundary, railroad workers. San Isidro had also gained some respectable notoriety in the pre-independence years as the birthplace of independence hero, Jose Martí. ${ }^{4}$ At the beginning of the twentieth century, with more than 5,000 inhabitants, it was a congested area with poor housing, unsanitary conditions, and socio-economic vulnerability. ${ }^{5}$ The streets were filled with the energy and endless activity associated with congested, working class neighborhoods. Although not a true tourist attraction, San Isidro certainly benefitted from the tourist trade and was a welcome sojourn for sailors while in port invariably looking for relaxation.

\section{Prostitution, Abakuás, and Bolita}

By and large, throughout its history Havana was perceived by visitors as a city whose women were invisible. One observer described it as essentially a male city populated by

${ }^{3}$ For a look at socio-economic issues in San Isidro after 1959, see Henry Louis Taylor, Inside a Barrio: a Bottom-up View of Neighborhood Life in Cuba (Sterling, VA: Kumarian Press, 2009), 149-166.

${ }^{4}$ In 1922, a grateful Havana renamed Paula Street in San Isidro, "Leonor Pérez," in honor of Martí's mother. In addition to the Railroad Station, the district is also home to the Cuban National Archives and the Iglesia de las Mercedes, an outstanding example of eighteenth-century Baroque architecture. For an overview of the development of Havana streets and buildings, see Juan de las Cuevas Toraya, 500 años de construcciones en Cuba (Madrid: D. V. Chavin, 2001).

${ }^{5}$ The 1919 Census of Cuba reported 6,584 inhabitants for San Isidro. United States Department of War, Report on the Census of Cuba, 1919 (Washington, D.C.: Government Printing Office, 1920), 156. 
priests, soldiers, sailors, and thousands of Spanish immigrants who flocked to the island seeking economic gain but had little intention of settling there. Another observer sighed that "women are scarce and those who in the least respect themselves are seldom or never to be seen abroad, except in their carriages at the Prado, in their boxes at the Opera, or behind the iron gratings at their windows." ${ }^{\prime 6}$ In fact, the male to female ratio in the province has often been reported as about three to one; however, census figures consistently show a very different picture, with the gender distribution for the city being almost even. ${ }^{7}$ Nevertheless, in Havana, respectable women generally did not venture outdoors. ${ }^{8}$ It was so uncommon for women to be seen on the streets that foreign ladies unacquainted with the custom drew curious onlookers and comments that sometimes “degenerated into impertinence.”9 As one observer noted, in Havana women generally were left to mope alone at home, "playing bo-peep with the passers-by from the window gratings, or pacing the flat roof of their house.” 10

In 1910, Irene Wright had described Havana as being a city of contrasts. On the one hand, the morals of a very Iberian and moralistic culture forbade elite and middle-class

${ }^{6}$ Gallenga, Cuba: The Pearl of the Antilles, 29, 37.

${ }^{7}$ For a discussion of marriage patterns in Cuba during the eighteenth century see Johnson, The Social Transformation of Eighteenth-Century Cuba, 97-120.

${ }^{8}$ Luis Martínez-Fernández, Fighting slavery in the Caribbean: The Life and Times of a British Family in Nineteenth-Century Havana (Armonk, NY: M.E. Sharpe, 1998), 65.

${ }^{9}$ Frederic M. Noa, The Pearl of the Antilles: A View of the Past and a Glance at the Future (New York: Knickerbocker Press, 1898) 36-37.

${ }^{10}$ Ibid., 38-39. 
women from going out alone in public; they could not attend funerals or shop unaccompanied. When young women walked down Havana's streets, albeit in tightfitting gowns, they were chaperoned everywhere they went. Men of all social classes, on the other hand, would position themselves on the narrow streets so that women passing by would have to come very close, sometimes forced to brush against them. ${ }^{11}$ Such double standards allowed men (especially those among high society) who felt constrained by the restrictive social norms that valued chastity in women and sexual prowess in men, to make their way to the streets of barrios like San Isidro.

The district's building facades were among the oldest in the city and communicated directly onto the narrow streets making engaging in "courting” rituals especially appealing. Well-meaning travelers in part misinterpreting the visual images Havana's architecture provided, reported that the "good conduct" of Havana women was reserved for the "native-born.” They were also quick to point out that "the professional profligacy, the symptoms of which are everywhere only too conspicuous and stare you in the face from many open windows in the principal streets, is of Spanish or American, at all events, altogether, of foreign importation.”12 Prostitutes were often described in terms of their race and nationality; “negras, mulatas, blancas, españolas, francesas, y

\footnotetext{
${ }^{11}$ Wright, Cuba, 95-97.

12 Noa, The Pearl of the Antilles, 38-39.
} 
norteamericanas," lined up block after block in San Isidro, with "horribly painted white faces and deep red lips” sitting by their window grates. ${ }^{13}$

Social traditions of appropriate roles for women, both within the Cuban family and the community, restricted employment opportunities, especially for white women. Carefully constructed public and private spaces insured that the women's influence was relegated to traditional roles within the private space: "the woman is at home and the man is on the street.”" ${ }^{\prime 4}$ Motherhood and female domesticity were revered in Cuba's moralistic, romantic tradition for women, and traditional cultural values, that excluded women from

${ }^{13}$ Eduardo López Bago, El Separatista: Novela Médico-Social: Primera Parte De Una Tetralogía (Charleston, SC: Nabu Press, 2010), 74.

${ }^{14}$ María del Carmen González, "La cultura popular en el drama cubano del siglo XX,” (Ph.D. Dissertation, University of Florida, 1984), 8. For a discussion of the struggle for legal rights of Cuban women and the men who supported them, see K. Lynn Stoner, From the House to the Streets: The Cuban Woman's Movement for Legal Reform, 1898-1940 (Durham: Duke University Press, 1991). The historical literature on gender and citizenship in the U.S. is varied. See, for example, Candice Lewis Bredbenner, $A$ Nationality of Her Own: Women, Marriage, and the Law of Citizenship (Berkeley, University of California Press, 1998); Nancy Isenberg, Sex and Citizenship in Antebellum America (Chapel Hill: University of North Carolina Press, 1998); Sabine Wichert and Mary O'Dowd, eds., Chattel, Servant, or Citizen: Women's Status in Church, State, and Society: Papers Read Before the XXIst Irish Conference of Historians (Institute of Irish Studies, the Queen's University of Belfast, 1995). For Latin American perspectives see Donna M. Goldstein, Laughter Out of Place: Race, Class, Violence and Sexuality in a Rio Shantytown (Berkeley: University of California Press, 2003); Daniel Balderston and Donna J. Guy, eds., Sex and Sexuality in Latin America (New York: New York University Press, 1997); June Nash and Helen Icken Safa, eds., Women and Change in Latin America : New Directions in Sex and Class (Hadley, MA: Bergin and Garvey, 1985) ; June Nash and Helen Icken Safa, eds., Sex and Class in Latin America (New York: Praeger, 1976); Asunción Lavrín, "Suffrage in South America: Arguing a Difficult Case," in Caroline Daley and Melanie Nolan, eds. Suffrage and Beyond: International Femenist Perspectives (New York: New York University Press, 1994); Asunción Lavrín, Women, Feminism and Social Change in Argentina, Chile, and Uruguay, 1890-1940 (Lincoln: University of Nebraska Press, 1995); and Lola G. Luna and Norma Villarreal M, Historia, género, y política: movimientos de mujeres y participación política en Colombia, 1930-1991 (Barcelona: Promociones y Publicaciones Universitarias, 1994). 
occupations requiring contact with men, effectively undermined female agency. ${ }^{15}$ Except for teachers, employment outside the home was not acceptable for married women and the vast majority of female wage-earners were either single or widowed. War and reconcentration efforts of the 1890s had displaced many women from the countryside and widows in post-war Cuba represented 50\% of the adult female population. "The life of a woman is very sad here in Cuba," journalist Wright commented, "the only right a woman had was the right to starve to death when her support failed.”16 This distinction crossed lines of race and class. ${ }^{17}$ Prostitution became a viable alternative for many women in Cuba.

Prostitution had a long and celebrated history in Cuba and in particular, in the capital city. Benjamin de Céspedes, in his 1888 study of prostitution and disease, noted that crew members who accompanied Columbus, as early as 1493, “prostituted” Indian women. ${ }^{18}$ The subsequent arrival of large numbers of single, young men as

${ }^{15}$ For example, Luis Martínez-Fernández argues that "of all the major cities in the New World, nineteenth-century Havana placed the most stringent limitations on the female population”; Luis Martínez-Fernández, “Life in a Male City,” in Fighting Slavery in the Caribbean, 44.

${ }^{16}$ Wright, Cuba, 101.

${ }^{17}$ Pérez notes the predominance of single and widowed in most female occupations by citing the ratios of single or widowed women to the total female workforce. In the professional ranks, 518 of 646 teachers were single or widowed and most were white. Among the occupations where women of color predominated, the single and widowed again were in the majority: 15,388 out of 20,980 laundresses; 19,970 out of 22,807 servants; 1362 out of 1580 cigar workers; and 342 out of 419 seamstresses. Pérez, Between Reform and Revolution, 210.

${ }^{18}$ Benjamín de Céspedes, La prostitución en la ciudad de la Habana (Havana: Establecimiento Tipográfico O’Reilley, 1888), 62-64. In a broad look at changing attitudes to syphillis, Claude Quétel argues that by the close of the nineteenth century 
conquistadores and colonists was accompanied by mujeres de mal vivir, who, according to Céspedes, had escaped from the persecution of the Inquisition. ${ }^{19}$ Céspedes noted that during the eighteenth century, while several governors of the island made sweeping reforms toward "good government," none addressed the issue of prostitution, so inculcated was its necessity for the economic interests of the island. A move toward reform was made in 1776 when the Marquis de la Torre established the Casa de Recogidas to house the large numbers of "delinquent and rowdy" women who lived on Havana's streets. ${ }^{20}$

doctors used the fear of venereal disease to extend their influence not only a kind of public health police, but also as arbiters of a "modern" morality; see Claude Quétel, History of Syphilis, translated by Judith Braddock and Brian Pike (Oxford: Polity Press, 1990).

${ }^{19}$ Herrera, in Céspedes, La prostitución, 66. In a letter to the King, dated 23 December 1584, Bishop Luján accused the mayor, the town's chief military officer, and the sergeant of "housing" several women. By 1657 the accusations sent to the Spanish Crown included charges against the Bishop of Havana, J. Manuel Montiel, and various priests and friars, contending that the poisoning of the previous Bishop, Diez Vara, resulted from disputes over prostitution among the clerics of the city. According to Céspedes, with the introduction of African slaves to Cuba, the prostituting of black women became a viable and profitable enterprise throughout the island as slave-owning entrepreneurs catered to the large numbers of white, single men who constituted the vast majority of Cuba's population. Thus, Céspedes argues, prostitution became the most practical means to satiate sexual needs for the transient population; Céspedes, $L a$ prostitución, 71.

${ }^{20}$ Ibid, 66-71. Havana's charitable social institutions founded under the auspices of the Catholic Church included "Casa de Depositos” (1687), "Casa Cuna” (1705), "Real Casa de Beneficiencia” (1792), and "Casa de Maternidad de María Santísima y San José” (1830). In 1852 these were combined as the "Real Casa de Beneficencia y Maternidad de La Habana.” Alberto Boix Comas. Así es Cuba!! (Habana: Cía. Petrolera Shell de Cuba, 1955), 76; and Ned Sublette, Cuba and Its Music: From the First Drums to the Mambo, Volume 1 (Chicago, IL: Chicago Review Press, 2004), 136. 
The first attempt to regulate prostitution in Cuba materialized in 1873. In April of that year, Governor Pérez de la Riva ordered that a hospital be opened to treat the large numbers of syphilitic prostitutes in the capital. Prostitutes were to be registered and licensed, with proceeds used to pay the expenses of the Hospital de Higiene that opened in June 1873. On December 27, 1873, the first regulations and laws governing prostitutes were published. Four-hundred prostitutes were listed in the registers for the inaugural year. $^{21}$ Using the revenue from the 30 pesos 80 centavos annual "license" fee, these women were to be examined at home twice weekly, once for a general external exam and once internally by use of a speculum. Many prostitutes, however, unable to pay the heavy fee, became fleteras (streetwalkers), often living and performing services between parked carriages and rail cars or in the alleys of the city. ${ }^{22}$

By 1875, military authorities, complaining that $10 \%$ of the armed forces were infected with syphillis, demanded that the government issue more stringent regulations. Instead, that year Dr. Claudio Delgado was appointed Director of Physician Hygenists and drafted a new study of the prostitution “problem,” La Higiene especial de la prostitución en la Habana, su estado actual y reformas que exige el ramo, called for more stringent enforcement of existing regulatory decrees.

The regulations and fees became fodder for political debate and the prostitutes' plight was used as a convenient tool against the Spanish Crown's colonial policies. On

${ }^{21}$ Céspedes, La prostitución, 74-75.

${ }^{22}$ Ibid.,79; Tomas Fernández-Robaina, Recuerdos secretos de dos mujeres públicas (Havana: Editorial Letras Cubanas, 1983), 85-86. 
September 9, 1888, La Cebolla, a Havana newspaper reportedly published by and for prostitutes although it has been credited to Victorino Reineri, a Spanish anarchist and activist, protested other new regulations in an editorial: "It is sinful,” the editor complained; "it is unconstitutional. It is a miscarriage of justice against unfortunate women who seek to carry out their business under the auspices of the law, for which they pay a hefty fee."23 Two weeks later the paper published an unsigned letter, supposedly from a prostitute; it further denounced the new reforms and regulations: "The Mayor, who is old and cranky, so that not even a fly dares to land on him, has disposed that we cannot exhibit ourselves in the doorways of our own establishments.” The writer further complained, "Is this fair? What country prohibits the businessman from showing the public his merchandise? The 'horizontals' of this city pay more contributions to the state than necessary. Yet, although we contribute more than any other sector to bolster the revenues of the state with the sweat of our ... brows, we are treated as if we were slaves; as if we were outlaws. In other words, we are considered citizens so as to meet our obligations, but not to enjoy the rights of citizenship. ${ }^{, 24}$ In total, the four editions of $L a$ Cebolla published in September of 1888 included centerfolds of "popular" prostitutes fully—if tantalizingly—clothed: Charo, Carmen la Rubia, La Madrileña and in the fourth

\footnotetext{
${ }^{23}$ La Cebolla, 9 September 1888.
}

${ }^{24}$ Four editions were published; La Cebolla, 9, 16, 23, and 30 September 1888. 
and last edition of the paper, La Criolla. ${ }^{25}$ Perhaps having made its point, the newspaper was not published after September.

In spite of protests, the movement for the regulation and/or the abolition of prostitution continued in Cuba as elsewhere. Increasing cases of disease among prostitutes and their clients in the 1880s and subsequent decades and the inability of the government to pass meaningful regulatory measures had spurred Céspedes to join many of his contemporaries in conducting "scientific" studies of prostitution. This coincided with many analyses of prostitution produced at a time when proving modernity was a priority for many nations. At the turn of the twentieth century, in countries such as France, Spain, England, Argentina, Brazil, and the United States, doctors, scientists, and women activists "studied” prostitution, its causes, and its regulation, especially the danger from disease. ${ }^{26}$ A second concern, culminating in the League of Nations' inquiries into the problem and subsequent resolutions, was the traffic in "white slaves.” The "white slavery scare” gripped progressive nations during the early decades of the twentieth century. The profusion of white slavery tracts that appeared in the U.S. between 1908 and the 1920s, attested that "the indignation and concern over white slavery was intense, widespread,

${ }^{25}$ For a discussion on the role of La Cebolla in nationalistic discourse, see Beatriz Calvo Pena, "Prensa, política y prostitución en La Habana finisecular: El caso de La Cebolla y la 'polémica de las meretrices,’” Cuban Studies: 36 (2005): 23-49.

${ }^{26}$ See, for example, Constancia Bernaldo de Quirós and Jesús María Llanas Aguilaniedo, La mala vida en Madrid: estudio psico-sociológico (Madrid: B. Rodríguez Serra, 1901); Paulina Luisi, El problema de la prostitución: abolicionismo o reglamentarismo (Montevideo: Sindicato Médico del Uruguay, 1926); George Jackson Kneeland, Commercialized Prostitution in New York City (New York: Century, 1913). 
and often hysterical;” readers were titillated with exotic tales of kidnapped innocents and their misadventures at the hand of the slavers. ${ }^{27}$

At the turn of the twentieth century, the debate over state regulation of prostitution and efforts (however weak) toward its control or abolition were considered essential by the new Spanish-American nations, including Cuba, in order to be to be recognized as a part of a "modern" world. ${ }^{28}$ By the second half of the nineteenth century, prostitution and its

${ }^{27}$ Mark Connelly, The Response to Prostitution in the Progressive Era (Chapel Hill: University of North Carolina Press, 1980), 114-15. For contemporary accounts, see Ernest A. Bell, Fighting the Traffic in Young Girls, or War on the White Slave Trade (Chicago: n.p., 1910); Jane Addams, A New Conscience and and Ancient Evil (New York: Macmillan, 1923); Albert Londres and Eric Sutton, The Road to Buenos Ayres (London: Constable and Co., 1928); Nylian Molinari Calleros, La trata de blancas (Buenos Aires: N.p., 1933); Cuba passed legislation to show its compliance with the League of Nations recommendations in 1925: Reglamento de la ley de inmigración y de las trata de blancas (Habana: Imprenta y Papelería de Rambla, Bouza, y Cía., 1925). Although the colonial government provision that established the Comisión de Higiene in 1873 required annual reports, I was only able to locate reports for 1888, 1902 (when by Military Order the regulations were adopted by the military government and were later extended to the republic until 1951) 1912, and 1914. In 1899, Reglamento de la prostitución en la ciudad de La Habana was published by the Comisión the Higiene Especial, adopting the colonial legislation for "independent” Cuba. See also Céspedes, La prostitución en la ciudad de la Habana ; Ramón M. Alfonso, La prostitución en Cuba y especialmente en la Habana, memoria de la Comisión de Higiene Especial de la Isla de Cuba (Havana: P. Fernández, 1902); Ramón María Alfonso, Reglamentación de la prostitución, breves apuntes como debe ser en Cuba (Havana: Havana: A. Miranda, 1912, 1912); and Matías Duque, La prostitución, sus causas, sus males, su higiene (Havana: Rambla, Bouza, y Compañía, 1914).

${ }^{28}$ During the last three decades there have been numerous studies of prostitution and its control during the $19^{\text {th }}$ and $20^{\text {th }}$ centuries. For studies of gender and nation building for Victorian England see Judith R. Walkowitz, City of Dreadful Delight (Chicago: University of Chicago Press, 1992); Judith R. Walkowitz, Prostitution and Victorian Society: Women, Class, and the State (New York: Cambridge University Press, 1980). For a discussion f prostitution in Argentina, see Donna J. Guy, "Prostitution and Female Criminality in Buenos Aires, 1875-1937,” in Lyman L. Johnson, ed., The Problem of Order in Changing Societies: Essays on Crime and Policing in Argentina and Uruguay, 1750-1940 (Albuquerque: University of New Mexico Press, 1990), 89-116; Donna J. Guy, Sex and Danger in Buenos Aires: Prostitution, Family, and Nation in 
control had become hotly debated topics both in Europe and the Americas. The massive immigration from Europe during the last two decades of the century renewed the zeal of “enlightened” nations to "clean up” the urban centers and "protect” their citizens. In

Argentina (Lincoln: University of Nebraska Press, 1995); Donna J. Guy, "White Slavery, Public Health and the Socialist Position on Legalized Prostitution in Argentina, 19131936," Latin American Research Review 23, no. 3 (1988): 60-80. Other important studies on gender images and prostitution in nation building used in support of particular political interests, see Sueann Caulfield, "Getting into Trouble: Dishonest Women, Modern Girls, and Women-Men in the Conceptual Language of Vida Policial, 19251927," Signs 19, no. 1 (Autumn 1993): 147. See also Sueann Caulfield, "The Birth of Mangue," in Daniel Balderston and Donna Guy, eds., Sex and Sexuality in Latin America (New York: New York University Press, 1997). Other studies that engage the demographics of prostitution have focused on specific regions within a country to observe community trends in dealing with prostitution. For Argentina, see Liliana Graciela Isabello, “La prostitución y la trata de blancas: 1874-1886," Todo es Historia 18, no. 223 (November 1985): 83-92, which notes the lack of enforceable prostitution regulations in Buenos Aires at the close of the 19th century. For a demographic analysis of prostitution in the Territorio Nacional de la Pampa, see María Herminia Di Liscia, María Silvia Di Liscia, and Ana María Rodríguez "Prostíbulos y control estatal en el Territorio Nacional de la Pampa,” in Lidia Knecher and Marta Panaia, eds., La mitad del país: La mujer en la sociedad argentina (Buenos Aires: Centro Editor de América Latina, 1994), 129-42; and Lilian Diodati, "Prostitutas, burdeles y reglamentos en la ciudad de Colón (Provincia de Buenos Aires),” in Knecher and Panaia, eds., La mitad del país: La mujer en la sociedad argentina. (Buenos Aires: Centro Editor de América Latina, 1994), 111-28. For Mexico, arguing for a spatial rather than a moral segregation of zonas on the U.S.-Mexican borderlands, James R. Curtis and Daniel D. Arreola, "Zonas de Tolerancia on the Mexican Border,” Geographic Review 81, no. 3 (1991): 333-44; and William E. French, "Prostitutes and Guardian Angels: Women, Work, and the Family in Porfirian Mexico, 1876-1911,” Hispanic American Historical Review 72: 4 (November 1992), 529-54, which argues that Mexico followed a North-American/European pattern in addressing prostitution issues as part of their efforts toward modernity. Compare with Lynn Stoner, who argues that the women's movement in the early Cuban Republic was uniquely Cuban in its motivation, demands, actions, and outlook and did not follow Anglicized models; K. Lynn Stoner, From the House to the Streets (Durham: Duke University Press, 1991). Fewer studies still have focused on the male procurer's role in defining the forms of prostitution or its politics. Few studies of the mechanisms of prostitution in Cuba have been published and, except for the anecdotal history by Tomás Fernández Robaina, they deal with prostitution in the post-Revolution years; see Julia O’Connel Davidson, “Sex Tourism in Cuba," Race and Class 38, no. 1 (1996): 39-50; and, tangentially, Lois M. Smith and Alfred Padula, "Twenty Questions on Sex and Gender in Revolutionary Cuba,” Cuban Studies 18 (1988): 149-58. 
masculine displays of modernity, a cadre of male politicians, criminologists, doctors, and other professionals—at times aided by female activists — targeted prostitutes in morality and public health campaigns on both sides of the Atlantic. For Spanish America modernity was the elites' vehicle for luring foreign capital, and "the aims of urban authorities [in Spanish America] included transforming the capital cities into showcases of dynamic modern nations ... and liberal professionals believed that their policies would accelerate progress, understood as a linear process through which both urban space and the culturally and ethnically diverse Latin American populations would come to resemble those of white, industrialized Europe."29 Having come late to independence, Cuba struggled to "catch up" to the rest of Latin America as it sought to define "Cuban" in white, northern European terms. At the state level this meant consolidation of the nation—although European immigration was seen as the "salvation of the nation," as it was seen in Argentina. ${ }^{30}$ At the cultural level, following Martí-style nationalism, a new kind of anti-imperialist and populist nationalism surfaced.

Often, however, there was a sharp cleavage between official rhetoric about and responses to prostitution and the realities in the streets. Unlike their more respectable counterparts in the city, San Isidro's women were at least employed and visible as they plied their trades. At the turn of the century Cuba, more than 2,440 women engaged in prostitution, the fourth largest source of employment for women on the island. After the U.S. occupation in 1898, the provisional government did not act expeditiously in issuing

\footnotetext{
${ }^{29}$ Caulfield, “Getting into Trouble,” 149.

${ }^{30}$ Helg, "Race in Argentina and Cuba," 37-69.
} 
restrictions on prostitution, although the U.S. was actively engaged in the international debate about prostitution; perhaps it was a low priority or seen as a way to provide some assistance to soldiers and sailors assigned to Cuban duty. It was not until 27 February 1902 (when U.S. troops were preparing to leave the island) that Military Order \#55 adopted the Reglamento General for the practice of prostitution both for Cuba and sought to segregate the prostitution trade, particularly in Havana. ${ }^{31}$ Within the approved zones, prostitutes catered to the vibrant maritime traffic, the large number of mostly single, male immigrants who arrived regularly, and to military personnel both Cuban and U.S.

A detailed demographic analysis of the island's prostitutes was offered by Ramón Alfonso, Secretary of the Comisión de Higiene Especial in his 1902 annual report. ${ }^{32}$ Unlike the large number of immigrants in the prostitute sector in countries such as Brazil and Argentina, in Havana, the vast majority of prostitutes were hijas del país (585 of the 744 counted for Havana were Cuban born). The prostitutes concentrated in the capital where the 1899 census listed more than 700 prostitutes living in some 338 brothels. ${ }^{33}$

${ }^{31}$ Milo Adrián Borges, ed., Compilación ordenada y completa de la legislación cubana, 1899-1950, Vol. I, Second edition (Havana: Editorial Lex, 1952), 94.

${ }^{32}$ Although the colonial government provision that established the Comisión de Higiene in 1873 required annual reports, only reports 4 reports are available: 1888, 1902 (when by Military Order the regulations were adopted by the military government and were later extended to the republic until 1951) 1912, and 1914. In 1899, Reglamento de la prostitución en la ciudad de La Habana was published by the Comisión de Higiene Especial, adopting the colonial legislation for "independent" Cuba. See also Alfonso, $L a$ prostitución en Cuba y especialmente en la Habana; Alfonso, Reglamentación de la prostitución; and Duque, La prostitución.

${ }^{33}$ United States Department of War. Report on the Census of Cuba, 1899. Washington, D.C.: Government Printing Office, 1900. The number of brothels is cited by Pérez; compare with 270 brothels in Havana by the late 1950s. Pérez, Between Reform and Revolution, 305. For a discussion on changing ideas of leisure and recreation 
More than half of Havana's prostitutes were born in the capital, while most of the rest had emigrated from provincial capitals or other national urban centers. ${ }^{34}$ These women worked in Havana's zonas de tolerancia in the oldest parts of the city, by the wharfs and industrial sectors such as San Isidro. Alfonso also noted that unlike the statistics published by Céspedes in 1888, who found that $60 \%$ of Havana's prostitutes were black, by 1902 white prostitutes were in the majority (64\%). In addition, Alfonso found that although prostitutes from the western provinces (Pinar del Río, Havana, and Matanzas) were less educated than those from the eastern part (Las Villas, Puerto Principe, and Santiago de Cuba); nevertheless, the large numbers from all regions were illiterate. ${ }^{35}$ Foreign-born prostitutes included Spaniards, Mexicans, and Puerto Ricans with a few other nationalities represented in small numbers. Of the 744 prostitutes counted, 425 were white, over 300 were illiterate, and a majority listed previous occupations as servants; a few had been laundresses and seamstresses (the most common occupations for women in Cuba according to the 1900 census). These women, generally between the ages of 18 and 25, poor and illiterate, represented the most marginalized sector of the economy. ${ }^{36}$ Many outside observers of the period held that the Cuban condition would

in Havana, with an emphasis on U.S. tourism to Cuba between 1920 and 1960, see Rosalie Schwartz, Pleasure Island (Lincoln, Nebraska: University of Nebraska Press, 1999.)

${ }^{34}$ Pérez, Cuba: Between Reform and Revolution, 207-208; and Céspedes, La prostitución, 157-59. For figures on Brazil, see Caulfield, "Birth of Mangue," 89; on Argentina, see Donna Guy, Sex and Danger, 104-105.

${ }^{35}$ Alfonso, La prostitución, 18-33.

${ }^{36}$ Pérez, Cuba: Between Reform and Revolution, 207-208. 
not be improved in such an environment of immorality and prostitution that hindered modernity and economic opportunity. ${ }^{37}$

In Cuba, female sexuality seemed to fuel all sides of the nationalistic discourse. The creole elite's home-and-hearth rhetoric regulated prostitutes and discriminated against the lower classes. The prostitutes both inside and outside the zonas de tolerancia in Havana, boasted a strict moral and social hierarchy that proposed to carve out a small sector of order in the turbulence of nation building. Especially in San Isidro, perhaps the oldest and most notorious community in Havana, there existed a "manifest camaraderie, true friendship, and solidarity ... The barrio had its ethical and moral standards and whoever

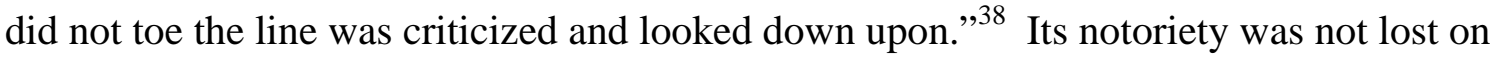
North Americans. “There are districts in Havana--one street, in particular--where, I am told,” Wright reported, “indecency beggars the average man’s imagination . . . [and] inspires many visiting women to drive, with their husbands, through this section.”39 Incidents reported in local newspapers simply read "lo de San Isidro" in identifying prostitute problems. ${ }^{40}$ San Isidro gained fame as a gathering place for prostitutes, pimps, free living, for harboring Afro-Cuban religious syncretism, and as home to all types of vices. It was described as a place where "the strongest of human passions [found] a counterpoint in racial co-existence, popular religion, and even in politics.”

\footnotetext{
${ }^{37}$ Helg, Our Rightful Share: The Afro-Cuban Struggle for Equality, 1886-1912 25.

${ }^{38}$ Fernández-Robaina, Recuerdos secretos, 41.

${ }^{39}$ Wright, Cuba, 97.

${ }^{40}$ Diario de la Marina, morning edition, 22 November 1910.
} 
The hierarchy of prostitution within the barrio depended on the nature of the prostitute; the more mobile, the less respected within the prostitution community. ${ }^{41}$ In San Isidro, members of the community differentiated among established prostitutes and fleteras (streetwalkers). On the one hand, those prostitutes who had a room or a house were held in highest regard, for even though they were at the mercy of policemen bent on extortion, they had some protection under the law. Matrons and pimps who kept their own house and had several women working for them were at the top of the social order, independents who rented a room by the month came next, fleteras ranked lowest in the female community. ${ }^{42}$ Fleteras were regularly rounded up and often beaten in the streets before being sent to the vivac, or local civil prison. ${ }^{43}$ Whether these distinctions were a result of the differentiations originally imposed by government officials in the Reglamentos or had originated within the community itself is difficult to ascertain. ${ }^{44}$

Several additional distinctions were also evident among the prostitutes. Ethnic and racial discrimination existed, although apparently not between prostitutes; it was in the clientele that racial differentiation became an issue. While Consuelo, a prostitute who lived in San Isidro during Yarini's time, reportedly slept with men of all races, many of the other

${ }^{41}$ For a discussion of similar hierarchies in other contemporary societies, see Reay Tannahill, Sex in History (New York: Stein and Day, 1980), 357-64.

${ }^{42}$ Fernández-Robaina, Recuerdos secretos, 29.

43 Ibid., 15,17.

${ }^{44}$ The reglamentos of 1899 listed several categories of prostitutes each with a different maximum monthly tax including casas con pupilas, 35 pesos; casas de aisladas, 12 pesos; casas de citas, 35 pesos; meretrices ambulantes, 5 pesos. Each of these categories was subdivided into five levels with different levels of taxation; Reglamento, 20. 
women would only sleep with white men. ${ }^{45}$ French women who regularly arrived in San Isidro after 1900 were seen as a threat to the social order in San Isidro, especially by Cuban women, since they were supposedly more sensuous and created a new standard for the barrio. ${ }^{46}$ "Religion” was also important for established prostitutes in San Isidro and it was common to see a prostitute cross herself for good luck before her first trick each night; none were beyond consulting a brujero (santería practicioner) if things were not going well. ${ }^{47}$ Race, domicile and buena suerte defined the most desirable prostitute.

The pimps of San Isidro also held different positions and demanded varying degrees of respect within the community. ${ }^{48}$ There were the "working” pimps who were employed on the wharfs, in banks or industry, or as white collar workers, depending on their social status. Another group, the “delinquent” pimps, sold drugs, and committed burglaries or petty thefts to get by. "Real” pimps did no work at all. The most respected, such as Suavecito ("smoothly"), had several women, while others had but one each with whom

${ }^{45}$ Fernández-Robaina, Recuerdos secretos, 72. The memoir published and edited by Fernández-Robaina mingles the recollections of two prostitutes, Consuelo and Violeta la Charmé. Since it is at times almost impossible to distinguish which of the two is speaking, throughout the rest of the essay Consuelo's name will be used as representative of the two.

${ }^{46}$ One French matron, waiting in Cuba for a visa to immigrate to New Orleans, is said to have left the island with thousands of dollars in profits. Ibid., 72.

${ }^{47}$ Ibid., 55, 90.

${ }^{48}$ Few studies still have focused on the male procurer's role in defining the forms of prostitution or its politics. For 20th century U.S. see, for example, Katyal, "Men Who Own Women," 791-826. For an early and sympathetic look at procurers, see Danero, El Cafishio. 
he lived in a common-law relationship. ${ }^{49}$ On the lowest rung of Havana's social ladder within the prostitute community were the café con leche pimps. These men were distinguished as the poorest and least respected. Unlike most of the "respectable" pimps who owned apartments and cars, the café con leches lived in the parks or had to hang out in the streets, waiting for the "woman" to finish with a customer, as he had nowhere else to go. ${ }^{50}$ One prostitute noted with indignation that one could easily differentiate between pimps, since café con leche pimps had to suffice with cheap watches, while the more "respectable” ones flashed expensive gold watches, bracelets, and large diamond rings. The worst insult one prostitute could hurl at another was that she belonged to a café con leche pimp. ${ }^{51}$

If their working habits distinguished the status of pimps in Havana, so did their dress. A 1908 narrative by one of Havana’s police inspectors, Rafael Rocha Monteagudo, of a typical chulo described a man who dressed to attract attention wearing a brown hat formed in specific folds with brim bent down low over the eyes. The individual often

${ }^{49}$ In Spanish the term suavecito is often used to describe smoothness and softness; Concise Oxford Spanish Dictionary(Oxford: Oxford University Press, 2005); in Spanish it is a colloquialism that implies the effortless social manner of someone who is romantically overly demonstrative (from zalamerías in Diccionario de la lengua española (Madrid: Espasa-Calpe, 2005), http://www.wordreference.com, accessed 9 January 2011. The English use of the words "suave" implies a man who is smoothly charming, confident, and elegant, but may be insincere; http://oxforddictionaries.com, accessed 9 January 2011. The Urban Dictionary defines suavecito as a "smooth guy," someone who is a player, http://www.urbandictionary.com, accessed 9 January 2011.

${ }^{50}$ In 1908, La Policía y sus misterios reported that there were domestic and clandestine chulos - those who kept houses of women and those who managed fleteras. Rafael Roche Monteagudo, "Proxelestes," in La policía y sus misterios (La Habana: Imprenta La Prueba, 1908), 186-87.

${ }^{51}$ Fernández-Robaina, Recuerdos secretos, 30. 
sported yellow shoes and red or other brightly colored socks. He wore no coat, but instead wore fancy shirts with bright splotches of bright colors or drawings over pinstriped pants. The outfit was completed by a carved walking cane. With "powdered faces and over-perfumed," chulos typically wore their hair with a curl carefully draped over the forehead and often sported long and bushy sideburns. The author reported that the men often spoke in loud voices and spent the day playing dominos, drinking cheap liquor, and keeping tabs on their women from nearby cafes. At night, they would return to their women and "beat them because their earning were not enough or because of jealousy over their affections to clients." ${ }^{52}$ The chulo was thus generally considered "a criminal - a guayabito - a rufian of the ill life."53

In contrast, Yarini, although a chulo, was described in different terms. It was said he wore only white linen and his bearing was described as elegant and refined. Members of the community were reportedly fascinated as he rode by on his white horse, or when he strolled the narrow sidewalks with his pair of hounds. ${ }^{54}$ His underwear was said to be hand embroidered with the initials AY- testimony of a quiet elegance that did not demand attention. ${ }^{55}$ Yarini was known as a man of soft and measured speech and in San

${ }^{52}$ Monteagudo, “Proxelestes,” 186-187.

${ }^{53}$ Ibid., 40-41.

54 “Testimony of Carlos Oliver, 1987,” in Lenardo Padura Fuentes, El viaje mas largo (Havana: Ediciones Unión, 1994), 177.

${ }^{55}$ Yarini, however, did own a pair of yellow shoes. After Yarini's death, among the personal effects collected by his father in June 1911 were several gold and mother of pearl shirt buttons, several pair of cufflinks, at least two made of U.S. gold coins and another set of mother of pearl, a diamond cravat pin and a gold pocket watch with hammered gold León tine (pocket watch holder) and a gold and diamond dragon charm. 
Isidro everyone looked up to him; "everything he did was good," remembered an observer, “except take the girls’ money which was good for him, but not for them.”56 Nevertheless, San Isidro prostitutes reportedly were happy to be with him - it was a mark of honor to be one of his women. Yarini had one additional characteristic that made him popular - and feared "ni como guapo ni como chulo." Although some denied it, most believed Yarini was a ñañigo, a member of one the most feared and respected group in the north-central part of Cuba, especially in Havana. ${ }^{57}$

Also known as Abakuás, ñañigos were members of secret societies that organized exclusively in Cuba and which initially worshipped the spirit of the African god Ekfe/Abakuá. Ñáñigo societies were especially powerful because adherents held to a code of honor and brotherhood that supported and protected its members against "outsiders."58 Their slogan, which emphasized their cultic brotherhood, was "partner and friend." Members were generally considered orilleros, or marginalized and were usually from the ranks of the poor and socially ostracized, although some very prominent

He also owned two straw hats and a few bullets; ANC, Audiencia de la Habana, Legajo 643/3, Folio 247-248.

${ }^{56}$ Fernández-Robaina, Recuerdos secretos, 50.

${ }^{57}$ Monteagudo, La policía y sus misterios, 187.

58 José A. Escarpanter and José A. Madrigal, Carlos Felipe: Teatro (Boulder, CO: Society of Spanish and Spanish-American Studies, 1988), 60. One of Ñáñigismo's characteristics which surfaced in popular culture was the use of colloquialisms such as mayimbe for a leader or chief; parna for friend; and la jara for the police. According to Consuelo (or Violeta) la Charmé, prostitutes in San Isidro generally called the police la jara, a ñáñigo term; Interview with Gisela Arandia , 2 April 1997, Rockefeller Fellowship Scholar, Florida International University, Miami, Florida; and FernándezRobaina, Recuerdos secretos, 40-45. See also, Jorge Castellanos and Isabel Castellanos, Cultura afrocubana (Miami: Ediciones Universal, 1994). 
Cubans were leaders in the sect. Cuban children were scared into obeying with threats that the ñànigos would get them (a Cuban version of the "bogey man”). Although relatively small in numbers, their influence was singled out by observers of the period commenting on the Cuban condition who often cited the blight of the "mulata, the ñañigo, and lazy blacks” as the root cause of Cuba’s inferior heritage and failure to achieve its potential. ${ }^{59}$

At first, Abakuá associations were the equivalent of mutual aid societies and were established in Cuba by free African-born urban males. Patterned after fraternal societies in the Calabar region of Nigeria, the cabildos de nación, as Afro-Cuban lodges were known, provided assistance to members experiencing difficulties. ${ }^{60}$ The groups often used the leopard as their symbol to represent masculine prowess and political influence, which were considered the mark of a true member. ${ }^{61}$ Beginning in the 1830s, after they

${ }^{59}$ Helg, Our Rightful Share: The Afro-Cuban Struggle for Equality, 1886-1912, 25.

${ }^{60}$ The term ñañigo was also used to designate African street dancers, especially those who paraded through Havana on Three Kings Day; they were also called diablitos and wore a festive and colorful costume with a cone-shaped hat. For a discussion of ñañigo practices and origins see Fernando Ortiz, La Tragedia de los Ñañigos, (Habana: Publicigraf, 1993); Matt Childs and Toyin Falola, eds., The Yoruba Diaspora in the Atlantic World (Bloomington, IN: Indiana University Press, 2005); "'The Defects of Being a Black Creole': The Degrees of African Ethnicity in the Cuban Cabildos de Nación" in Jane A. Landers and Barry Robinson eds., Slaves and Subjects: Blacks in Colonial Latin America (Albuquerque: University of New Mexico Press, 2006), 209-245. For an analysis identity tensions between the African-born and Cuban-born members of fraternal societies in early 19th century Havana see Philip A. Howard. Changing History: Afro-Cuban Cabildos and Societies of Color in the Nineteenth Century (Baton Rouge: Louisiana State University Press, 1998).

${ }^{61}$ The foundational work on ñañigos is presented in Fernando Ortiz's work on African influences in Cuban expressive arts, Los brujos negros (Miami: Ediciones Universal, 1973). For a popular survey of Afro-Cuban characters in Cuban literature 
began to admit creole Afro-Cubans, these societies sprang up in Cuba's major port cities of Havana and Matanzas, with a small number of lodges as far east as Cardenas. ${ }^{62}$ With expanding networks and accessibility, within two decades there were more than twenty cabildos in the region and with the admission of mulatos and the creation of an all-white lodge, cabildo numbers increased to over one-hundred at the height of participation in the late nineteenth century. ${ }^{63}$ Havana's wharves were not only home to the poor, laborers, prostitutes, and chulos, they also served as gathering points for ñañigos who congregated in areas such as San Isidro where police often winked at those just beyond the law. The classic ñañigo job was as a stevedore and, in San Isidro, they controlled the job markets of the docks. ${ }^{64}$

from the 1880s to the close of the twentieth century, see, Santiago Massetti, "El origen de la religiosidad del cubano: El que no tiene de congo, tiene de carabalí," online article, Agencia Periodistica Mercosur (8 June 2010), http://www.prensamercosur.com.ar/apm/nota_completa.php (accessed 15 September 2010) .

${ }^{62}$ Monteagudo equates the ñañigo pact of avenging brothers to the Sicilian mafia’s view that only their members can truly bring about justice in avenging a member of the family. He cites a study of the time, Mafia e Delinquenza en Sicilia. Menteagudo, "Proxelestes," 11.

${ }^{63}$ Ivor Miller, Voice of the Leopard: African Secret Societies and Cuba (Jackson: University Press of Mississippi, 2009), 178. Abakuá lodges did not spread to other parts of Cuba. It is interesting that Jose Leopoldo Yarini Klupfel had made the transition from Havana to Matanzas about the same time as the expansion of the Abakuá lodges to Matanzas occurred. See Monteagudo, for a list of “juegos de ñañigos” from Matanzas and Havana.

${ }^{64}$ Sublette, Cuba and its Music, 205. 
Figure 6

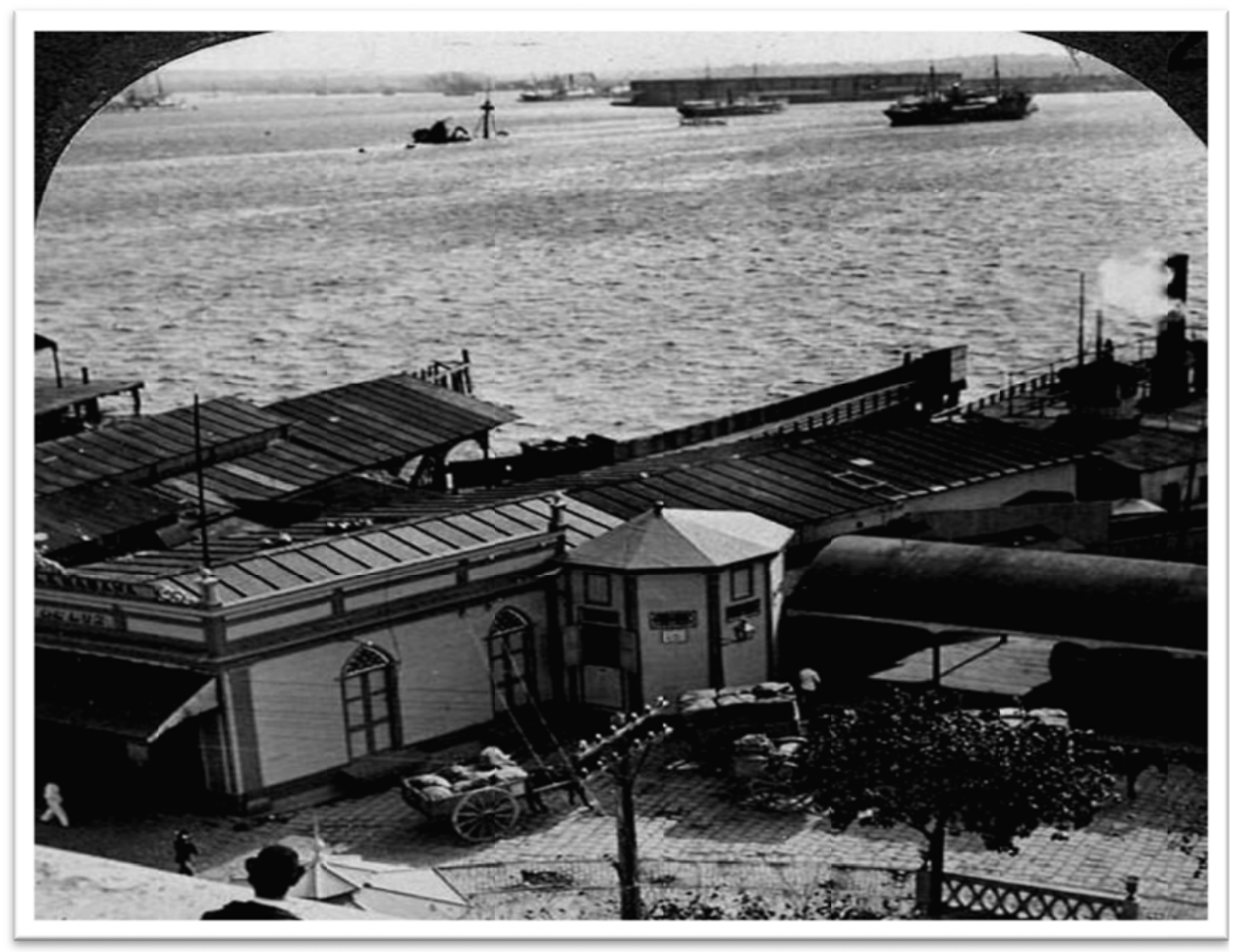

Havana’s Muelle de Luz c. 1900

Source: http://secretoscuba.cultureforum.net/t14434-fotos-de-cuba-solamentes-deantes-del-1958 (accessed 14 December 2010), image posted by QUANG, 22 July 2009.

In his 1908 narrative of issues of interest to the police, Monteagudo noted that by 1908, religion was ancillary to the ñañigo societies. Like many adherents to the pseudo-science of eugenics, he concluded the ñañigo was a criminal by birth and extremely dangerous as opposed to the brujo, a type of witchdoctor, whose role was religious and whose weapons 
were spells, not guns. ${ }^{65}$ The secrecy of the cabildos, which instituted secret rituals and ceremonies especially for member initiation and funerals, sometimes including symbolic funerals for a member who had betrayed the cabildo secrets or another brother, added to their allure. Abakuá ceremonies, although widely known in Cuba, were shrouded in secrecy. It is reported that during his initiation, the ñañigo swore to defend and revenge his cabildo brothers -sometimes the oath was sworn on a crucifix or some other object with religious connotations including African fetishes. ${ }^{66}$ The oath obligated a member of the juego (group) to avenge any grievance against a brother. Abakuás expected brothers to be industrious and law abiding, a protector of his ñañigo brothers, in short "good fathers, good children, good siblings and good friends.” One of Ñáñigismo’s other unique characteristics that surfaced in popular culture was the use of unique colloquialisms such as mayimbe for a leader or chief; parna for friend; and la jara for the police. For example, according to Consuelo la Charmé, prostitutes in San Isidro generally called the police la jara, a ñáñigo term. ${ }^{67}$

${ }^{65}$ Monteagudo, “Proxelestes,” 14-15. The ñañigos’ unique cranial characteristics are described in pages 30-40 of the same report. For a discussion of eugenics in Cuba see Bronfman, Measures of Equality.

${ }^{66}$ Monteagudo, “Proxelestes,” 10.

${ }^{67}$ Fernández-Robaina, Recuerdos secretos, 75. For issues of religion and the meaning and uses of fetishes see Brown, David. "Toward an Ethnoaesthetics of Santería Ritual Arts: The Practice of Altar Making and Gift Exchange," in Santería Aesthetics in Contemporary Latin American Art, edited by Arturo Lindsay, (Washington, D.C.: Smithsonian Institution Press, 1996), 77-146; Michael Atwood Mason, Living Santeria: Rituals and Experiences in an Afro-Cuban Religion (Washington, D.C.: Smithsonian Institution Press, 2002); Miguel Willie Ramos. "Afro-Cuban Orisha Worship," in Lindsay, ed., Santería Aesthetics in Contemporary Latin American Art, 51-76; and Stephan Palmié, Wizards and Scientists: Explorations in Afro-Cuban Modernity and Tradition (Duke University Press, 2002) 
Notwithstanding the adoption of ñañigo terms into the language, the rapid growth of Abakuá associations alarmed colonial authorities who repressed the groups and in 1885 banned them outright. In derogatory terms, Spanish colonial authorities referred to all Afro-Cuban insurgents as ñañigos. ${ }^{68}$ Members swore oaths not to reveal the cabildos’ ceremonies and initiation rites, forged binding, lifelong pacts of fraternity among members, and espoused African religious overtones that led to mistrust of the groups and repressive actions of Spanish authorities, forced the associations to go underground. Ñañigos became "scapegoats, accused of committing heinous acts." ${ }^{\text {69 }}$ Depictions of Cuba’s Abakuá in literature are generally associated with violence, vengeance, and irrational behavior. $^{70}$

Abakuás were feared and became notorious for their reputation of sacrificing humans at their initiations, charges that were never substantiated. In 1902, several were tried and convicted of the crime although it was not clear how the sentence of two to four years imprisonment and a fine of 1000 pesos each, fit the crime of cannibalism. ${ }^{71}$ Recent studies have suggested that ñañigos as a group were active participants in the wars of independence and instrumental in the formation of labor organizations. It is reported that 81.

${ }^{68}$ Helg, Our Rightful Share: The Afro-Cuban Struggle for Equality, 1886-1912,

${ }^{69}$ Miller, Voice of the Leopard, 139.

${ }^{70}$ For a discussion of the role of the Abakuá in Cuban culture and literature, see Castellanos and Castellanos, Cultura Afrocubana; and Mercedes Cros Sandoval. Worldview, the Orichas, and Santería: Africa to Cuba and Beyond. (Gainesville: University Press of Florida, 2006).

${ }^{71}$ The charges were later dropped for insufficient evidence. Helg, Our Rightful Share: The Afro-Cuban Struggle for Equality, 1886-1912, 107-108. 
a covert squadron of ñañigos had secretly escorted Antonio Maceo into the capital although Maceo never knew it. ${ }^{72}$

By the beginning of the $20^{\text {th }}$ century, members were generally considered orilleros, or marginalized and were usually from the ranks of the poor and socially ostracized, although some very prominent Cubans were reputed to be leaders in the sect. Cabildos were often officially repressed because they were viewed as detracting from official efforts at modernity. Their practices were viewed as contrary to public morals and regulations were passed that made ñañigos easier to prosecute than brujeros (santeria practicioner priests often considered a type of witch). ${ }^{73}$ The official stance backfired and the myth that developed about the Abakuá, so shrouded in secrecy and fancy, soon became a symbol for Cubans across social and racial continuums. The honor code of the Abakuá and their defense of their members made membership sought after by a broad class of individuals. Elite, white, black, poor, educated, and illiterate, all were brothers in this most democratic of Cuban institutions. “To be Abakuá was to be Cuban” - during colonial times it meant that a member sided with creoles -even if they were from the marginalized classes_-rather than with what was seen as the privilege and oppression of

${ }^{72}$ Antonio Maceo has been referred to as "Ngo La Habana” (Leopard of Havana). Miller, Voice of the Leopard, 147-148.

${ }^{73}$ Bronfman, Measures of Equality, 21-23. 
Spanish peninsulars. ${ }^{74}$ Later, Cuban politicians, seeking the working-class Afro-Cuban vote, openly courted ñañigos to establish their political clout among orilleros.

Among those politicians was José Miguel Gómez, General of the Liberation Army, who as the leader of the Liberal Party was elected as the second president of the Cuban Republic in 1908. The Gómez Liberals ran a campaign based on the need to restore Cuban identity after the end of U.S. occupation. Their symbol, a cock on a plough, and slogan of "bring back the cock," elicited nationalistic memories of a pre-U.S. occupation Cuba where cockfighting was legal and Cuban culture was not censored by foreign interests—a Cuba for Cubans. ${ }^{75}$ In fact, after he won the 1908 elections, restoring cockfights, after a ten-year ban, was one of Gómez’ first official acts. Cockfighting, however, was largely a rural sport in Cuba; in urban areas, many viewed bolita (also known as "numbers") not as an illegal gambling activity, but as a reasonable means to earn extra money. ${ }^{76}$ The re-establishment of the lottery, however, was opposed by

${ }^{74}$ Ivor Miller also claims that Maceo was Abakuá but offers no evidence; Miller, Voice of the Leopard, 177. For a discussion of the role of cabildos and sociedades in the colonial and early national period see Bronfman, Measures of Equality.

${ }^{75}$ Cockfighting and the lottery had been banned by Leonard Wood in 1898 . In 1904 Senator Morua Delgado rushed a lottery re-establishment act through the Congress, but President Palma vetoed it. Thomas, Cuba or the Pursuit of Freedom, 511-12. The Cuban lottery was under the direct control of the government and the officials who ran it personally benefitted from its revenues; see Charles Chapman, A History of the Cuban Republic: A Study in Hispanic American Politics (New York: Octagon Books, 1969), 547-63. Perhaps cockfighting was seen as a uniquely "Cuban” pastime, much as bullfighting was associated with Spanish imperialism by many Cubans. Bullfighting was also outlawed by the U.S. military government on October 10, 1899, but was not reinstated by a republican Cuba; Louis A Pérez, Jr. "Between Baseball and Bullfighting: The Quest for Nationality in Cuba, 1868-1898," Journal of American History 81, no. 2 (Sept. 1994): 493-518.

${ }^{76}$ Bolita is known as “drop-hand” in Jamaica. 
Martín Morúa Delgado, Afro-Cuban veteran and a Gomez Cabinet appointment, who had publicly warned in 1905 that if the lottery was established Cubans would know that "an insurmountable wall has been raised to separate the nation of which we dreamed ... from that which really exists." ${ }^{\text {77 }}$ Nevertheless, within a year after Gomez’ election, legislation was passed in Congress to establish a national lottery that would ostensibly provide funds for public works projects; this was described by supporters as perhaps Gomez' "most dazzling achievement."78 The Gomez administration controlled the lottery licenses and collected a significant percentage of the revenues generated. ${ }^{79}$ The vacuum of leadership that such a corrupt system engenders was not lost on Yarini who adeptly began his political ascent in the Conservative party on a platform that challenged the corruption of the Gomez presidency—albeit with a corruption of its own.

\section{How to become "King"}

Bolita's history in Cuba probably dated back to the influx of Chinese workers of the mid and late $19^{\text {th }}$ century. ${ }^{80}$ The bolita lottery system was based on a list of consecutive

${ }^{77}$ Martín Morúa Delgado quoted in Chapman, A History of the Cuban Republic, 512.

${ }^{78}$ Thomas, Cuba or the Pursuit of Freedom, 513.

${ }^{79}$ In another of the many personally enriching deals Gómez transacted during his administration, he traded the old arsenal grounds just off Havana Harbor and near San Isidro to the U.S. controlled United Railways as the site of their new dock and depot, infuriating the barrio residents and Cuban investors. There was a public outcry at the deal Gómez had made and two Congressmen fired shots during the debate on the issue in the House. Bradley, Havana: Cinderella's City, 404.

${ }^{80}$ For a discussion of the Chinese in Cuba using historical and literary texts, see Lisa Yun, The Coolie Speaks: Chinese Indentured Laborers and African Slaves of Cuba (Philadelphia: Temple University Press, 2008). Yum points to Antonio Chuffat Latour, 
numbers from 1 to 100 , each with a specific meaning. The first 36 were taken from the Chinese "Charade" that emigrated with the first indentured Chinese laborers; the rest was a truly Cuban addition, the product of popular imagination. Picking numbers was a popular sport and dreams served as a sort of magical kabala to identify winning lottery numbers. From the listing in a "dream book" players would select and purchase the appropriate numbers; for example, a dream of riding a horse might entice the participant to play the number 1 ; a dream about a policeman may have precipitated buying a chance on the number 50. Bolita was viewed not as a criminal offense, but rather as an opportunity to earn extra money for anyone who could afford the nickel wager. ¿ंTú sabes qué salió anoche? (Do you know what number was picked last night?) was the talk of the barrio in the mornings. It seemed everybody played bolita, so after just a few months in Cuba, even the most guileless newcomers knew the significance of the numbers. ${ }^{81}$

Bolita was also a communal sport with groups of wagers and curious onlookers congregating each night in cafes around the city to watch the outcome. In the evenings,

Apunte histórico de los chinos en Cuba (1927), as the earliest text to frame Chinese life in Cuban history.

${ }^{81}$ Bolita became institutionalized in 1909 as the National Lottery and was an enormous source of profit and payoffs; Nancy Hewitt and Suzanne Lebsock, eds., Visible Women: New Essays on American Activism (Urbana: University of Illinois Press, 1993), 203. The Gómez presidency established state gambling bureaus and reserved a quota of collectorships or ticket sales for administrators and members of both houses of congress, "a senator holding ten collectorships stood to supplement his salary by as much as \$54,000 during difficult economic times;” Louis A. Perez, Jr., quoted in Sublette, Cuba and its Music, Vol 1, 317. A little over a decade after its inception and amidst charges of widespread graft and ticket scalping, it was reported that the Cuban lottery was grossing \$7.5 million; “National Lottery Causes Cuba Crisis,” New York Times, 27 June 1922. 
the bolita organizers would gather and place 100 small numbered balls into a velvet bag where they would be mixed thoroughly. With odds of 80:1 and a five cent investment, a laborer could earn $\$ 4.00$, while the house and numbers sellers pocketed $20 \%$ profit on the night's take; a good sum of money for a day's work at a time when U.S. diplomats earned about $\$ 25$ per week. Cheating was a way of life for bolita operators and the games were rigged using a variety of methods from weighted balls that would sink to the bottom of the bag, adding multiple balls of the same number and omitting other numbers, or introducing ice "chilled" balls that could be easily detected. ${ }^{82}$ Among his "other" enterprises, Alberto Yarini had built a private bolita empire that extended beyond San Isidro where his influence and gambling activities earned him the title of "el Rey de San Isidro" (the King of San Isidro). ${ }^{83}$

\section{Conclusion}

The ambivalence of Cuban nationalism was evident during Cuba's early national period as politicians clashed in their visions of a Cuba libre. Experiencing a colonial system of government in 1898, U.S. occupation and an uneasy independence in 1902, and a second U.S. occupation in 1906, Cuban government's stability was elusive. In San Isidro an ambivalent order prevailed. Abakuá membership provided a mechanism for solidarity if

${ }^{82}$ McIver, A Life of Duty, 69

${ }^{83}$ The semi-criminal behavior of wealthy U.S. business leaders is described in Ted Nace, Gangs of America. With a strong anti-corporate agenda, Nace traces the growth of corporate power in the U.S. from the pre-revolutionary era, to the beginning of the twenty-first century, noting violence against organized labor and elites' use of Social Darwinism as a justifier for enacting various forms of repression at the turn of the twentieth century. Ted Nace, Gangs of America: The Rise of Corporate Power and the Disabling of Democracy (San Francisco: Berrett-Koehler Publishers, 2003). 
a moral stigma for a new republic. Prostitution fueled the merchant economy but was seen as a throwback to a primitive past; its immorality and debauchery threatened Cuba's hope for acceptance into the modern nations of the world. ${ }^{84}$ In San Isidro, however, the daily expediencies of life continued and prostitution and gambling served to make an extra dollar for the working classes and cabildos provided opportunities and protection not available through official sources. In images reminiscent of the Wild West, life on the edge was acceptable: prostitutes peeked out from every barred window, racketeers profited on the "poor man's tax" (bolita), shootouts were a regular occurrence, election ballot boxes were stuffed, police and politicians were on the take. ${ }^{85}$ According to Wright, "the most notorious street in town [was] within a block or so of the most fashionable church and of the American Legation, opposite it. In short the 'old city' [was] a grab bag--its contents unsorted.”86

${ }^{84}$ Helg, Our Rightful Share: The Afro-Cuban Struggle for Equality, 1886-1912, 25.

${ }^{85}$ In the global context, Cuba, and Havana in particular, was no more corrupt than other urban centers such as Shanghai, London, or New York City. Between 1902 and 1903, for example, Lincoln Steffens, a journalist for the New York Evening Post, wrote a series of investigative articles which were published in McClure's magazine and published as one collection in 1904. Citing that in the U.S. "the politician is a businessman with a specialty," and with the goal of inciting the public to demand reforms, Steffens work exposed government corruption in many major U.S. cities including St. Louis, Minneapolis, Pittsburgh, Philadelphia, Chicago, and New York. See Lincoln Steffens, The Shame of the Cities (New York: McClure Phillips, 1904).

${ }^{86}$ Wright, Cuba, 10. 
Such "disorder" and ambivalence created a space for Yarini to emerge as "el más cubano de todos” (the most Cuban of all). ${ }^{87}$ As a quintessential public man, Yarini worked his clientele as the patrician with a following -the equivalent of the colonial adelantado "who took life by the horns and carved out a piece of the world for himself.",88 Elite, white, a proxeneta, and a ñañigo, by 1906, Alberto Yarini had found a place among the misfits of the barrio; he had become the King of San Isidro whose political and social patronage was a sought after commodity by prostitutes and politicians alike. ${ }^{89}$

87 "Carmen," (who refused to give her last name), personal communication with the author, on the streets of San Isidro, 27 January 2001.

${ }^{88}$ Anonymous, Juan Banal posting, $\underline{H}$-Latam@h-net.msu.edu, 28 February 2002.

${ }^{89}$ Escarpantier and Madrigal, Carlos Felipe, 50. 


\section{CHAPTER V}

\section{“PARA SUBSISTIR DIGNAMENTE”": YARINI THE PATRIOT}

"Freedom is not asked or begged for, it is won,” wrote Evaristo Estenoz, Liberation Army veteran and political activist, in the inaugural edition of Prevision, the official voice of the newly formed political party for Afro-Cubans, the Agrupacion Independiente de Color. "Rights are fought for [emphasis added by the author] and belong to all," he continued, "if we go on asking for our rights, we will die waiting because we will have lost them. Faith kills the spirit, when we have faith in others rather than ourselves, because it kills initiative.”2 Published on 30 August 1908, this sentiment of failed expectations and political disenchantment expressed by the Afro-Cuban population had widespread meaning among all Cubans searching for a "Cuba for Cubans.”3 Belligerence seemed a justifiable course of action in achieving aspirations of a unifying public dream, not the reality of how Cubans experienced life in the chaos of nation-building, but the dream of what they wanted to be.

\footnotetext{
${ }^{1}$ Diario La Marina, 25 September 1908.

2 Evaristo Estenoz, “Elección y Selección,” Prevision, 30 August 1908.

${ }^{3}$ Editorial, Prevision, 15 September 1908.
} 


\section{Ambivalent Nationhood}

Political ambivalence and disaffection were hallmarks of Cuban national rhetoric in 1908; it was said that in Cuba, nothing was more like a Liberal than a Conservative.

After a second occupation of the island by the U.S. in 1906, cubanidad was still trying to coalesce in terms of the "other." The debilitating ambivalence in defining cubanidad made political parties thoroughly porous and official recourse ineffective. As during colonial times, political organizations provided no clear ideology and party labels were largely meaningless. Instead, Cuba's fascination with the cult of personality that seeks out idealized heroic public figures led to the formation of countless political parties and factions. ${ }^{4}$ Political ideals often took a back seat to the individual search for power and wealth and men easily switched party allegiances as it became necessary. ${ }^{5}$

\footnotetext{
${ }^{4}$ As with many emerging states, Cuba's political parties were fluid with candidates often changing sides on a given issue. The Reformistas, Autonomistas, and Consevadores aligned along social and economic lines in the colonial period. The Partido Revolucionario Cubano, José Marti’s party formed in exile, had been abandoned with the beginning of the republic. Between 1899 and 1902, many more parties were formed, including the Partido Nacional Cubano (Estrada Palma's party), Liga Nacional Cubana (which also backed Palma), the Partido Federal Democrático (Santiago de Cuba), the Partido Republicano Federal (Las Villas), Unión Democrática (1900), Partido Republicano Independiente, Partido Moderado (1904) under the leadership of Morúa Delgado, the Partido Liberal (1905), founded by J Miguel Gómez, Bartolomé Masó and Alfredo Zayas) founded in opposition to the Estrada Palma candidacy. After the failed elections of 1906 and Palma's insolvency and inability to govern, his Moderate party dissolved and two major political parties emerged in anticipation of the 1908 presidential elections. The Liberal Historical Party, organized under the leadership of Eusebio Hernandez, Orestes Ferrara, and Martín Morúa Delgado, backed José Miguel Gomez for the presidency. Gomez was seen as a natural leaders and fighter who was respected by the American military government: "As Cuban politicians go, he [was] honest and [gave] evidence of rising as nearly to the level of true patriotism as any politician on the island"; MHS, Edwin Atkins Collection, Scrapbooks, newspaper clipping, 11 October 1906. The Liberal party, under the leadership of Afro-Cuban activists Juan Gualberto Gomez and
} 
For Cubans, achieving political identity proved repeatedly elusive. In 1901, the Republican Liberals, headed by José Miguel Gómez, and the National Liberals, headed by Alfredo Zayas, both had supported Estrada Palma’s bid for the presidency. By 1905 on the eve of a new election, however, the pervasive disillusionment of what had been accomplished in Cuba in the preceding four years, both Liberal parties and the recently organized Moderate Party, led by the Afro-Cuban Martín Morúa Delgado, accused the other parties of fraud in the elections. A new united Liberal Party reorganized in 1905 to challenge the Estrada Palma reelection bid, yet was unable to provide a unifying ideology for the country and again split into two factions after losing the elections. One faction was led by Gómez (miguelistas) and another by Zayas (zayistas) former running mates in 1905. ${ }^{6}$ The re-election of the moderate U.S. citizen Palma for a second term as president of the Republic of Cuba in the fall of 1905 was a great disappointment for the Liberal party. The Palma Conservative Republicans (moderates) were in power but being challenged by new political coalitions as Palma's style of government proclaimed a "Cuba for Cubans," but was based on what was perceived as North American political protocol.

Demetrio Castillo Duaney, backed Alfredo Zayas. Zayas was seen at best as a political organizer, but certainly not a fighter. He reportedly was a man of influence who "had many friends, bears himself with dignity, and lives simply and quietly"; MHS, Edwin Atkins Collection, Scrapbooks, newspaper clipping, 11 October 1906.

${ }^{5}$ Stoner, From the House to the Streets, 6-7.

${ }^{6}$ The Moderate party’s newspaper was La Discusión. 
After the election of Palma, liberals organized raids against the government across the island. ${ }^{7}$ By July 1906, reportedly under the leadership of Gómez, the defeated Liberal candidate for president, a full-fledged anti-Moderate and anti-Conservative revolution had materialized on the island. Palma, however, considered the skirmishes that ensued to be of little consequence and felt he could contain them with the resources at hand. Over the next month, the situation continued to deteriorate. In August 1906, in a clash outside Havana, popular revolutionary leader Quintín Banderas, having become an insurgent organizer, was killed, and a few days later Gómez was jailed, although reports held he did not participate in the rebellion but was jailed by the Palma administration for political reasons. ${ }^{8}$

With insurgents and the government's rural police force facing off throughout the country in late summer 1906, Palma began to offer cash for volunteers to strengthen government forces, requesting guns and about two million rounds of ammunition from supporters in New York. ${ }^{9}$ By September, the insurgents were engaging in machete fights with government forces and one hundred of Palma’s cavalry officers deserted and joined the insurgency. As things continued to go from bad to worse, Palma declared martial law

${ }^{7}$ Skirmishes were reported in Havana, Pinar del Rio, Santiago, Sancti Spiritu, and Santa Clara; MHS, Edwin Atkins Collection, Scrapbooks, newspaper clipping, 29 April 1910.

${ }^{8}$ MHS, Edwin F. Atkins Collection, Scrapbooks, newspaper clippings, 11 October 1906. Gómez was later released under the amnesty ordered by Secretary of War William Taft.

${ }^{9}$ George Washington Crichfield, American Supremacy: The Rise and Progress of the Latin American Republics and Their Relations to the United States Under the Monroe Doctrine, Volume 1, (New York: Brentano, 1908), 170-75. 
and requested U.S. warships be stationed in Havana harbor. The recently-elected Palma announced his resignation as President of the Republic on 25 September 1906 and more than a dozen U.S. warships and 11,000 troops stood ready to occupy the island. That same day Havana newspapers reported that the insurgent camp at La Lisa, outside of Havana, had become a tourist attraction of sorts. The report noted thousands of Habaneros "encouraged by reports that peace was imminent ... dared to gratify their curiosity and show their great sympathy for the revolutionary cause... Although it was raining yesterday afternoon, this did not dampen the ardor of those who wished to visit the insurgents. Many extra trolley cars were in operation ... but they were not sufficient as many walked the twelve miles from Havana to the [insurgent] camp." ${ }^{\prime 10}$

During the protests, both moderates and liberals worried about the social, economic, and judicial implications of renewed U.S. occupation. For example, La Discusión, a moderate newspaper considered the Palma government's semi-official voice, noted intervention would be "worse than death" for Cubans "both white and those of color." The editor warned that "the colored race may tremble before possible intervention ... Americans hate and despise Negroes. Even their own Negroes ... are treated like dogs, lynched and hardly considered human. If it is so with Negroes in their own land and language, what would happen to the Cuban Negro?” The warning continued, noting whites had much to fear as well; they would be displaced from their posts by men such as General Tasker Bliss, who as Administrator of Customs, demanded everyone speak English only. The judicial system would also be compromised because "instead of our deliberate and

${ }^{10}$ MHS, Edwin F. Atkins Collection, Scrapbooks, newspaper clipping, 25 September 1906. 
refined judges, we would have judges like Pitchers [Captain William Pitchers] with their '\$10 or ten days.”’ The notorious and hated Pitchers was the U.S.-appointed judge trying and sentencing misdemeanors in Havana. His style of passing judgment was viewed by Cubans as dismissive rather than the result of careful deliberation. In addition, the paper noted, Cuban womanhood was threatened by the arrival of "beer-drinking American officers with clanking spurs, masters of all, [who would ravish] our adorable virgins.”11 The liberals were more belligerent in their opinions as Faustino "Pino" Guerra Puente, leader of the liberal insurgents warned, "We want our independence ... Americans would make us slaves. The only intervention we want is new elections, otherwise, we fight back."12 Cubans were determined to regain control of their destiny even if once again through belligerent means.

Four days after Palma's resignation as a result of the insurrection, on 29 September, U.S. troops reoccupied Cuba and an uneasy peace ensued under Secretary of War William Taft as provisional governor. The following month Cuba once again was fully under U.S. military control and governed by President Theodore Roosevelt's appointee, Charles Magoon. It was becoming evident that the dream of Cuba libre was disintegrating and insurgency had become a spectator sport.

${ }^{11}$ Quoted in Crichfield, American Supremacy, 174-75.

${ }^{12}$ Quoted in Ibid., 175. For a description of the Liberal insurrection of 1906 by the self-proclaimed leader of the insurrection see Faustino Guerra Puente, "Causes of the Cuban insurrection,” North American Review. 183, No. 599 (21 September 1906), 53840 . 
As the U.S. occupied Cuba for a second time it installed a provisional government compelled to protect the substantial U.S. economic interests on the island. By 1907, however, the New York Times reported that "the settlement had proved so unexpectedly satisfactory, that ... the United States could withdraw and give those people another opportunity for self-government no later than [September of 1907].” The terms of withdrawal became a subject of acrimonious debate in Cuba, with the Times reporting that "while the parties had not agreed among themselves ... still they have agreed with [Secretary of War Taft] on the terms." ${ }^{\text {13 }}$ The report heightened tension and polarized public opinion in both the United States and in Cuba as U.S. politicians continued to debate appropriate strategies for withdrawal and Cuban self-government and Cuban political coalitions continued to realign along opportunistic lines. A September 1907 U.S. withdrawal did not occur. A year later, however, the 1908 national elections scheduled for November promised a new start for the Cuban Republic and a subsequent withdrawal of U.S. occupation forces in early 1909.

\section{A New Republic}

What political paradigm was to define the new republic this time around? Several factions proposed the answer. In the face of the general disaffection with Liberal politics, a new Conservative Party was organized in February 1907 under the leadership of Enrique José Varona, newspaper editor and professor at the University of Havana. Varona had held government posts during the U.S. occupation in 1898 as Secretario de Hacienda and Secretary of Public Education and Fine Arts where he implemented the

\footnotetext{
13 “Cuba Free September, 1908,” New York Times, April 28, 1907.
} 
"Plan Varona," for the modernization of public education in Cuba. Disillusioned, he had returned to his post at the University after Palma's election in 1902. The Conservative Party he helped found was the "elite's” party, representing Havana’s rich bourgeoisie, while the Liberals presented themselves as the party of the people. ${ }^{14}$ In 1907, La Razon, a self-proclaimed "political newspaper of general interest," reported that one of the Conservative's stated purposes was to "end the dissidence which divides and separates Liberal zayistas (Zayas’ party) and miguelistas (Gómez’ party), which today seems an impossible task.” ${ }^{15}$ The paper lamented that the many demonstrations across Havana that year were evidence of the lack of patriotism and love of Cuba by the leaders of both parties, "If Gómez and Zayas were patriots and had heartfelt love for Cuba, they would put aside the self-love that dominates them ... they would stop running for office ... would unite as one party," and elect a new president. The Diario de Cuba reported in April 1908 that "both Mr. Zayas and General Gómez pretend indifference at the new party, but the truth is that the Conservative Party is their highest preoccupation.” The editor warned that "both liberal groups [zayistas and miguelistas] will have to contend with the new party's determined and robust platform that will block the progress of

${ }^{14}$ When Mario Menocal ran unsuccessfully for the presidency on the Conservative party ticket in 1908, Rafael Montoro, although he strongly campaigned for the vice-presidential nomination of his party, was passed over as his running mate. Menocal was eventually elected in 1912 and served two terms. Varona became the Party's first elected Vice President under Mario Menocal from 1913-1917; Thomas, Cuba, or the Pursuit of Freedom, 489.

${ }^{15}$ La Razón. 23 June 1907. 
liberals’ ambitions." ${ }^{\text {16 }}$ Just coming of age at the time of its formation, Alberto Yarini would align himself closely with the new Conservative Party.

The Liberal party, reorganized in 1908 with new hopes of electoral success, this time lacked support from the vocal Afro-Cuban sector. Although the Liberal Army enjoyed the vast support of Afro-Cubans during the 1906 uprising, the Liberals strongly backed the Ley de Imigracion of the Palma government. ${ }^{17}$ The law allocated $\$ 1$ million to promote European immigration, especially white immigration, that had lured more than 150,000 Spaniards and thousands of other white Europeans to Cuba between 1899 and 1905, especially through the island's main port of Havana. These immigrants filled countless jobs to which displaced army liberators, most of them Afro-Cubans, aspired. ${ }^{18}$ In response to the Liberal platform that did not address their economic and political aspirations, Afro-Cubans organized their own party in 1908, in part, demanding an end to racial discrimination and a lifting of the ban on "non-white" immigration. ${ }^{19}$ Basing its hopes on political organizing, with each attempt, a sector of the Cuban population in

16 “Liberales y Conservadores,” Diario de Cuba, 14 April 1908

${ }^{17}$ Gott, Cuba: A New History, 121.

${ }^{18}$ Duvon C. Corbitt, "Immigration in Cuba," Hispanic American Historical Review 22, No. 2 (May 1942): 304-305; and Gott, Cuba: A New History, 107. See also Consuelo Naranjo Orovio and Armando García González, Medicina y racismo en Cuba: La ciencia ante la inmigración canaria en el siglo XX, (Tenerife: Centro de la Cultura Popular Canaria, 1996).

${ }^{19}$ The Partido Independiente de Color (PIC) founded in August 1908 grew at a tremendous rate. By 1910 it had more than 73,000 members, including 12 Afro-Cuban independence generals, 30 colonels, and more than 15,000 soldiers; Ada Ferrer, Insurgent Cuba, 145-59. 
Havana sought ways to gain a hold of their cubanidad through sundry organized official ways; others took things more personally.

Political posturing, popular opinion and opportunism, coupled with social upheavals and the growing political and racial tension on the island, proved a destabilizing and divisive combination for the new Republic. ${ }^{20}$ Arguably, such is the tumultuous nature of nationbuilding. Nevertheless, in Havana, expressions of cubanidad were challenged not only in political and military forums, but on every street corner, by both creoles and foreigners, by different classes and racees, in both orchestrated and spontaneous ways. If, as has been proposed by historians, in 1898 and its aftermath U.S. national interest was manifested in corporate mobilization through war and intervention in Cuba, for Cubans, national interest was often expressed in very personal terms. ${ }^{21}$

${ }^{20}$ The control of resources and revenues was the "central, if unstated, issue of politics at all levels of the [Cuban] republic.” As economic conditions worsened during the Cuban republic's first decade, so did corruption and patronage. According to Pérez, by $1903,20,000$ Cubans were on the public payroll with $40 \%(8,000)$ of those in the city of Havana; by 1911 the number had risen to 40,000 federal employees, requiring that two-thirds of the budget be expended for payroll. In Cuba at the turn of the twentieth century, politics was a matter of "economic and social urgency"; Pérez, Between Reform and Revolution, 205, 220.

${ }^{21}$ Many explanations have been proposed for U.S. intervention in the latenineteenth-century independence wars with Spain. Historians have reviewed a number of issues on the coming of War and the U.S. role in its outcome. The role of the press and of public opinion in the coming of the war see Joséph E. Wisan, The Cuban Crisis as Reflected in the New York Press, 1895-1898 (New York: Columbia University Press, 1934); Marcus M. Wilkerson, Public Opinion and the Spanish-American War (Baton Rouge: Louisiana State University Press, 1932); Thomas A. Bailey, The Man in the Street: The Impact of Public Opinion on Foreign Policy (New York: Peter Smith Publishing Company, 1964); John E. Mueller, War, Presidents, and Public Opinion (New York: Wiley, 1973); and Robert Hildebrand, Power and the People: Executive Management of Public Opinion in Foreign Affairs, 1897-1921 (Chapel Hill: University of North Carolina Press, 1981). The imperialistic and economic aspects of the war are the 
As with armed resistance, the defender of Cuban nationhood often derived popular appeal from the Machiavellian interplay between virtù, a successful leader's personal qualities (good and evil), and fortuna, the unpredictability of life and the inevitable enemy of political order. In the Machiavellian order, fortuna overcomes only when there is no suitable leader capable of varying her/his conduct from good to evil and back again "as fortune and circumstances dictate.,22 In Havana’s “theater of the street and the square,”

subject of a number of works including Ernest R. May, Imperial Democracy: The Emergence of America as a Great Power (New York: Harcourt, Brace, and World, 1961); David Healey, U.S. Expansionism: The Imperialist Urge in the 1890s (Madison: University of Wisconsin Press, 1970); Walter LaFeber, The American Age, 2 vols., (New York: Norton, 1994); Thomas G. Patterson, "United States Intervention in Cuba, 1898: Interpretations of the Spanish-American-Cuban-Filipino War," History Teacher 29 (May 1996) 341-61; Hugh de Santis, "The Imperialistic Impulse and American Innocence, 1865-1900," in Gerald K. Haines and Samuel Walker, eds., American Foreign Relations: A Historiographical Review (Westport, CT: Greenwood Press, 1981), 65-90; Joseph A. Fry, "William McKinley and the Coming of the Spanish-American War: A Study of the Besmirching and Redemption of a Historical Image," Diplomatic History 3 (Winter 1979), 77-97; Joseph A. Fry, "From Open Door to World Systems: Economic Interpretations of Late-Nineteenth-Century American Foreign Relationsm” Pacific Historical Review 65 (May 1996), 277-303; and Thomas Schoonover, Uncle Sam's War of 1898 and the Origins of Globalization (Lexington: University Press of Kentucky, 2003). U.S.-Cuba relations from the Cuban perspective were addressed by Enrique Collazo, Los Americanos en Cuba (Havana: C. Martinez y Comp, 1905); and José Antonio Medel, La Guerra hispano-americana y sus resultados (Havana : P. Fernández, 1929). Specialized studies have also used 1898 as a prism for describing issues of gender in U.S. belligerence. See, for example, Kristin Hoganson, Fighting for American Manhood: How Gender Politics Provoked the Spanish-American and PhilippineAmerican Wars (New Haven, CT: Yale University Press, 1998). The two major U.S. political parties in 1896 nominated perhaps the most devout pair of presidential candidates in American history: Methodist Republican William McKinley and Presbyterian Democrat William Jennings Bryan. Two years later, McKinley, the winning nominee, ushered in a new phase of "manifest destiny" when he led the United States to war against Spain; the focus on religious overtones of 1898 is found in Thomas A. Breslin, Rum versus Whiskey: The Great Anglo-Celtic Divide in the History of American Foreign Relations, forthcoming.

${ }^{22}$ Nicolo Machiavelli, The Chief Works and Others, A. Gilbert (trans.), 3vols., (Durham: Duke University Press, 1965), quoted in Stanford Encyclopedia of Philosophy, 
virtù capitalized on the instability provided by fortuna through a masculinity defined in terms of the individual's audacity and boldness expressed in male hegemonic action.

\section{Masculinity and Nationhood}

The Reciprocity Treaty and the Platt Amendment of 1903 had guaranteed economic and military "rights" to the U.S. and Cubans railed against such American hegemony in official and clandestine ways. ${ }^{23}$ In the face of perceived powerlessness through official and political channels, Cubans looked for a different kind of champion who could challenge the monolithic U.S. presence and the ineffective Cuban official responses to occupation and self-government. Cuba needed a classic "public man,” a real man who could act on behalf of the people and serve the cause of cubanidad on Cubans' own terms. ${ }^{24}$

It has been proposed that white men's masculinities can only be constructed through their oppression of "the beast": women, black men, or members of other cultures regarded as

http://plato.stanford.edu, (accessed October 21, 2009). Machiavelli’s virtù and conventional virtue differ in that the Prince must "maintain his state" and "achieve great things," and thus is expected to be capable of behaving in a completely evil fashion if the situation (fortuna) warrants. This is the basis of Machiavelli's recommendation that above all the Prince should acquire a "flexible disposition"; that alone constitutes true virtù. See also Sebastian de Grazia, Machiavelli in Hell (Princeton, NJ: Princeton University Press, 1975), 211-12; Hanna F. Pitkin, Fortune is a Woman: Gender and Politics in the Thought of Niccolò Machiavelli (Berkeley: University of California Press, 1984); and Roberto Pacheco, "Fortune is a Woman," Atlantic Millennium Journal, Vol. 2, 1994, 133-147.

${ }^{23}$ For a discussion of the terms and developments of the Platt Amendment in Cuba see Perez, Cuba under the Platt Amendment.

${ }^{24}$ Dealey, The Public Man, 44. 
inferior. In particular, the male proclivity is to "prove" masculinity through aggressive and violent behavior. Thus, the conflict between "hero" and "beast" differentiates two understandings of manhood and provides a framework for understanding hegemony. ${ }^{25}$ Hegemony, in turn, posits the successful claim to authority by whatever means. Hegemonic masculinity, then, has been described as the ideal and culturally normative male behavior in a society. It occupies the dominant position in a relational pattern-a position that is always contested —and is often positioned against a "marginalized" masculinity that disenfranchises a race or class. ${ }^{26}$ Relations between these different types of masculinities are often defined through alliances, dominance, and subordination. ${ }^{27}$ Such relationships are often underpinned by violence, and violence thus becomes a way of publicly asserting hegemonic masculinity. ${ }^{28}$ Certainly such expressions of masculinity were decisive in shaping the imagined Cuban nation.

After almost a half-century of insurgency against Spain and the resultant political instability of a dubiously obtained "freedom," Cubans were not exempt from their own hegemonic posturing. Some sought power through political machinations while others, such as Havana's elites in their ritualized expressions of nationhood, fought U.S.

${ }^{25}$ For a study of racial images in western discourse and the linkages between racism and sexism, see Paul Hoch, White Hero, Black Beast: Racism, Sexism and the Mask of Masculinity (London: Pluto Press, 1976).

${ }^{26}$ Connell, Masculinities, 77.

${ }^{27}$ Ibid., 37.

${ }^{28}$ Ibid., 83. For a discussion of masculinity and culture, especially in the U.S. South, see Edward E. Baptist, Creating an Old South: Middle Florida's Plantation Frontier before the Civil War (Chapel Hill: University of North Carolina Press, 2002), 88-119. 
imposition figuratively. Through elaborate public performances a new Creole elite sought to replace Spanish imperial class structures with those of their own making. For example, the statue of revolutionary hero and patriot of liberty José Martí in the Parque Central in central Havana had been dedicated in February 1905, during Palma's first term in office. The ceremony was marked with great pageantry and official speeches as Marti’s likeness was placed where a replica of the Statue of Liberty had stood—and from where a bronze of Queen Isabella had been removed in 1898. The ritual included a dignified and orchestrated parade through the streets. ${ }^{29}$ Other examples of republican showmanship such as the unevenly attended, although carefully orchestrated, public funerals of war heroes went largely unnoticed by the populace. Only a few such as that of Maximo Gómez in 1905, drew large crowds. Elites of the new republic crafted such displays as shows of political power and control where "the people" were allowed to participate in the pageantry only as spectators in rituals of a contrived cubanidad that further fostered the ambivalence of nation. Other Cubans, however, staked their claims to popular power more literally and "virtuously."

\section{The Spectacle of Masculinity}

On Tuesday evening, 22 September 1908, Alberto Yarini, president of the newly-formed Conservative party's committee for San Isidro, sat with ten or twelve of his friends at a long table in the small but crowded El Cosmopolita café in Havana. The café was

${ }^{29}$ For a discussion of the use of Marti's image in Cuba during the $20^{\text {th }}$ century as a source of coalescing nationalism, see Mauricio Augusto Font and Alfonso W. Quiroz, The Cuban Republic and José Martí: Reception and Use of a National Symbol (Lanham, MD: Lexington Books, 2006). 
situated off the Acera del Louvre, a sidewalk colonnade that served as the gathering place for Havana’s young creole aristocracy. ${ }^{30}$ In El Separatista, a novel by Eduardo López Bago, the draw of the popular sidewalk and its outdoor seating for Havana's youth was called a vice, it was described as an enticing spot where young aristocrats and underworld elites often met. ${ }^{31}$ The district's proximity to the fashionable Teatro Tacón not only attracted theatergoers, but also war heroes, journalists, musicians, and painters. The sidewalk in front of the café was especially known as a breeding ground for revolutionary conspiracies and expressions of resistance and bravado such as the incident of the "broken sword," when a Spanish military officer broke his sword in open protest over the shooting of several university students by Spanish regulars in $1871 .^{32}$ The Acera was reportedly the site of regular, if not frequent, tiritos bobos or "idle" shots - an oxymoron at best— which were never meant to kill, but delivered simply as a warning.

${ }^{30}$ Manuel Moreno Fraginals, Cuba/Espana, Esspana/Cuba, (Barcelona: Critica, 1996), 263.

${ }^{31}$ Ferrer, Insurgent Cuba, 146; and Eduardo Lopez Bago, El Separatista: novela medico-social: primera parte de una tetralogia, Part 1 (Charleston, SC: Nabu Press, 2010), 74. The novel is a treatment of separatist sentiment just prior to the outbreak of the Cuban-Spanish-American War and, while arguing the merits of separatism, concludes Cuba should not try to secede from Spain.

${ }^{32}$ Miller describes men who gathered at the café as "tacos - well dressed men with elegant mannerisms," although I have found no other reference to the term tacos for Cuba; Miller, Voice of the Leopard, 120. The Acera is also known because of its association with Nicolas Estevanez, a colonial Spanish military official, who in 1871, in protest over the students shot by Spanish authorities for supposedly desecrating a tomb in the Colon cemetery broke his sword in front of a crowd. A plaque on the Hotel Inglaterra and an annual ceremony commemorates this event; Marjorie Peregrin and Teresa de Jesus Torres, "Fundamentos y esencias en un acto de recordacion," Noticias Habana Patrimonial, Dirección de Patrimonio Cultural, 27 November, 2007, http://www.ohch.cu/noticias (accessed 21 September 2010). 


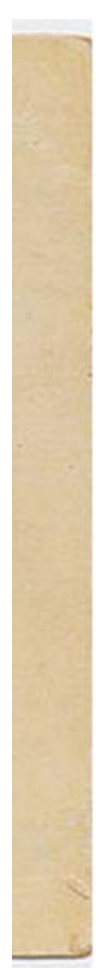

ard

1).

In a prime location on the Acera, El Cosmopolita café served as a popular gathering place for both locals and foreign visitors and was reputed as the only place in the city to get a good slice of “American” pie. ${ }^{33}$ E. deForest Winslow, an American journalist touting

${ }^{33}$ Perez, On Becoming Cuban, 126. The Café was situated next to the Hotel Inglaterra and remained a popular eatery well into the 1950s. See "Who's Who," Havana Magazine, Advertisement, July 14, 1938 from havanajournal.com/politics (accessed 25 August 2010); and Consuelo Kamholz Hermer and Marjorie May, Havana Mañana: A Guide to Cubans (New York, Random house 1941), archive.org/stream/havanamananaagui011712mbp; (accessed 25 August 2010). In 2001, 
opportunities in the plumbing supply trade in Havana, noted that El Cosmopolita not only provided good fare - if perhaps too heavy for "healthy” American stomachs—but also had the advantage that usually a fellow diner could translate an order for the non-English speaking waiters. ${ }^{34} \mathrm{El}$ Cosmopolita was a popular gathering place for American travelers and one of the most popular locations on the Acera. With its façade open to the broad sidewalk and its doors always thrown open, the café commanded a full view of the Parque Central.

As a young, politically aspiring aristrocrat, Alberto Yarini frequented the Acera de Louvre and often sipped coffee with friends at El Cosmopolita. Yarini, was especially known for putting action behind his words. He had been convicted of tiritos bobos numerous times, each time getting a slap on the wrist from authorities. ${ }^{35}$ First arrested at age eighteen, over the course of six years (August 1900 to October of 1906) Yarini had been arrested 22 times by Havana police, yet never received a significant sentence. Often the charges were dropped or he was fined the proverbial $\$ 10$ and released. His offenses included disturbing the peace, inflicting wounds, carrying and discharging a firearm, and

when the author visited the establishment, the café was still serving customers, although the fare had been reduced to café and a few "chucherías."

${ }^{34}$ E. de Forest Winslow, “A Glimpse of Havana,” Domestic Engineering and Journal of Mechanical Contracting 48, no. 864 (3 July 1909): 49.

${ }^{35}$ G. Cornell Tarler correspondence to Justo Garcia Velez, 14 October 1908; Microfilm, Series M862, Cabinet 43/5-45/3, Roll 907 (Sept. 1908), file group 14963, U.S. Department of State Numerical and Minor File 1906-1910, U.S. National Archives and Record Administration (College Park, MD) hereafter NARA II. 
one charge for "threats of death.” On 11 July 1905 Yarini was arrested for homicide, however, no record of a conviction was ever recorded; the case just disappeared. In spite of his long criminal record, in Havana Yarini was quickly acquiring a reputation as a brave and honorable man, despite his lucrative sidelines: prostitution and racketeeringinstead, he had gained a reputation as a "true friend" and a worthy representative of heroic Cuban manhood.

Figure 8

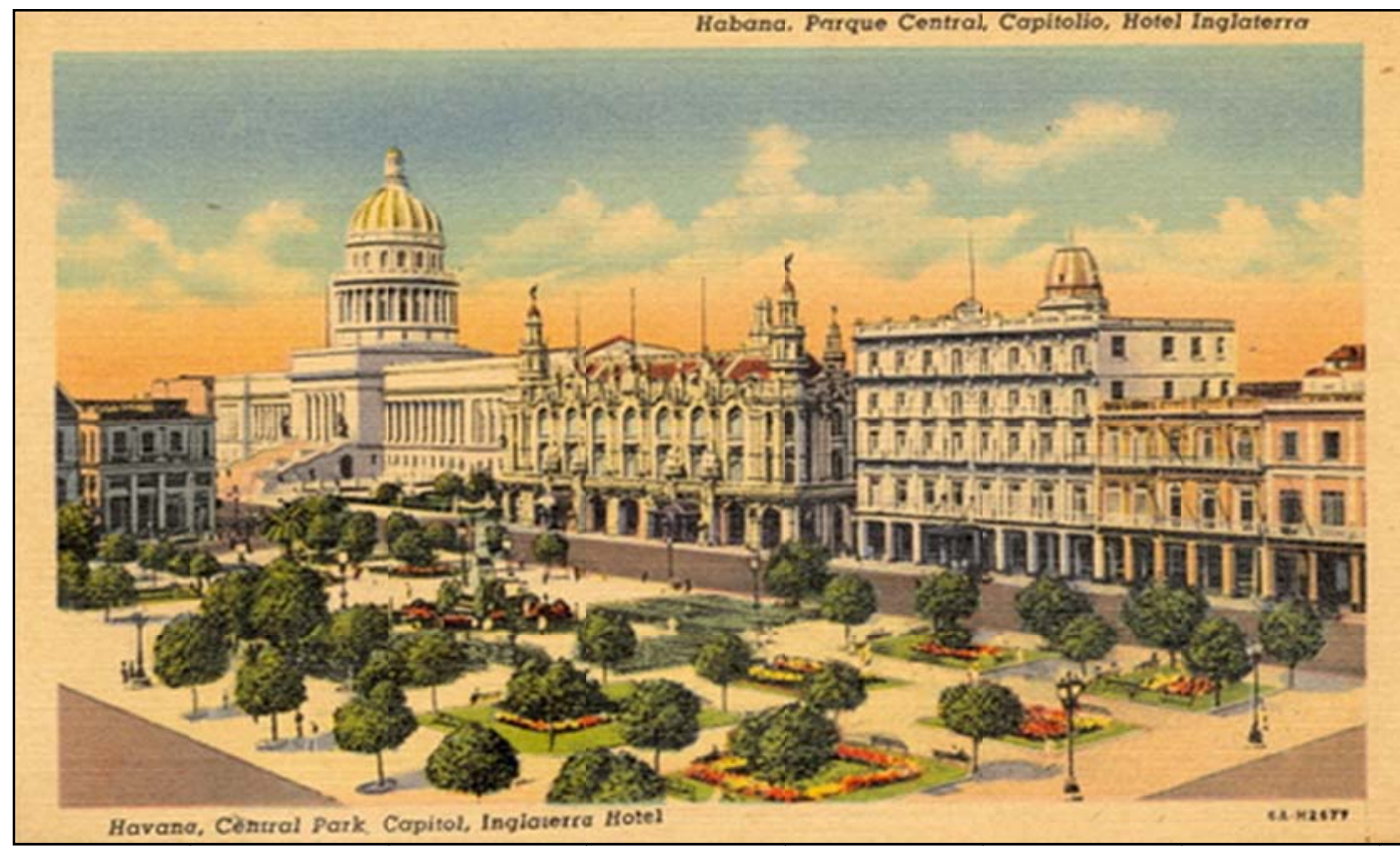

Parque Central

The Acera de Louvre colonnade facing Havana’s Parque Central. The Capitol building (1929) on the left was modeled after the U.S. capitol and is slightly taller; the Teatro Tacon (today the Gran Teatro de la Habana) is the ornate building in the center; and the Hotel Inglaterra (still in use today) is on the right.

It housed the El Cosmopolita café on the Acera.

Source: "Havana, Central Park, Capitol, Inglaterra Hotel," http://www.flickr.com/photos/9teen87/3523094419/ (accessed 15 January 2011). 
Among Yarini’s friends enjoying drinks and the balmy evening breeze at the Cosmopolita were several members of the Cuban Army later described as "aged negroes.”36 The group included the U.S.-educated Colonel Eugenio Silva, commander of the Holguín regiment during the independence war and member of the cabinet of the Republic in Arms, habanero Arturo Planas, and Liberation Army General Florencio Salcedo, commander from Baire, Oriente, veteran of three independence wars, and one of the leaders of the initial uprising against Spain in $1868 .^{37}$ The gathering was rounded out by several young Cubans who frequented the café, no doubt like Yarini, of the young aristocratic ilk. ${ }^{38}$ The group was engaged in a lively conversation about Cuba's political

36 “Cornell Tarler Assaulted by Cuban Politician in Cosmopolitan Café,” Havana Post, 23 September 1908.

${ }^{37}$ These three men were named by Alberto Yarini in his trial defense deposition and listed as possible witnesses; ANC, Audiencia de la Habana, leg. 224, no. 10. Eugenio Silva was an officer of Liberation Army, U.S.-educated, he held a number of posts in the Cuban Army from 1902 to 1924. After retiring, he worked to establish military type schools throughout Cuba and in 1943 was lobbying for his education plan to be adopted across the Americas as a means of hindering future dictatorships such as Hitler's; see Eugenio Silva, "Contribution of the Americas to the War and to Peace," Annals of the American Academy of Political and Social Science (July 1943): 21-24. After leaving the Army, Silva received a commission as Reciprocal Induction Agreement Officer in the United States and served as liaison officer for American troops with Spanish-speaking peoples. Perez argues that by 1921, Silva had espoused “'Americanization' as a strategy to defend cubanidad.” Silva equated American institutions and industry with being a vehicle to bring enlightment to Cuba - the U.S. was the example of progress and national development Cuba should follow; Perez, On Becoming Cuban, 162-63. Florencio Salcedo Torres (1852-1931) Dominican father and Cuban mother, he was head of the beginning of the Independence War in 1895 in Jiguani and a hero of the battle of Los Negros.” Mario Riera Hernández, Ejército Libertador, 1895-1898 (Miami: self published, n/d), 167-68.

${ }^{38}$ G. Cornell Tarler correspondence to García Velez, 14 October 1908; U.S. Department of State Numerical and Minor File 1906-1910, no.14963, NARA II. 
situation, reportedly discussing the rally for the Agrupación Independiente de Color that met just a few blocks away the previous evening.

The Agrupacion had been created in the aftermath of the provincial elections during the summer of 1908. Afro-Cuban candidates working within all the mainstream parties ran for municipal and provincial office and were resoundingly defeated in the elections on 1 August. Within a week, on 7 August 1908 just a few blocks away from the Cosmopolita, Afro-Cubans formed a new political party: the Agrupación Independiente de Color, which later became the Partido Independiente de Color (PIC). Under the leadership of Evaristo Estenoz and journalist Gregorio Surín, the Agrupacion became the first independent black political party in the Americas. Some have suggested the U.S. occupation imposed American "separate but equal values" on the Cuban people further complicating the existing racial tensions on the island. Technically, the Cuban Constitution of 1901 provided male suffrage based on property, literacy, and war service, making no mention of race. Practically, however, the equality implied in suffrage was not evenly applied. Troops of color received little in the way of recompense after the War and the institutions of the new Republic did not reflect the social composition of its people. For Afro-Cuban war veterans, "the race barrier became more unjust than ever."39 For example, of 205 national employees listed in the 1907 Census, only 11 were AfroCuban. ${ }^{40}$ Although black and mulatto voters made up about one third of voters (with

${ }^{39}$ Helg, Our Rightful Share, 119.

${ }^{40}$ Censo de la Republica de Cuba 1907, 210, 214-216. See also Rafael Fermoselle-Lopez, Politica y color en Cuba: La Guerrita de 1912 (Black Politics in Cuba: The Race War of 1912), (Madrid: Editorial Colibri, 1998); Aline Helg, Our Rightful Share; Silvio Castro Fernández, La Masacre De Los Independientes De Color 
higher concentrations in the cities), in the 1908 summer elections Afro-Cubans were able to elect few representatives to local and municipal posts.

The new party called for Afro-Cubans to desert the liberals and conservatives and instead assert their rights on their own terms. ${ }^{41}$ "The Republic's elections and the political parties' selection of candidates from the so-called colored race have shown many things,” wrote Estenoz, "the first is that the colored race of Cuba can expect nothing from the procedures used to date by the political parties ... by putting forward all candidates of color, as independents, it will be apparent to all that no matter how small a minority these results produce, it will be greater than what has so far been achieved by all the groups in the various parties." ${ }^{22}$ The association petitioned Lieutenant Colonel Enoch Crowder, whose job it was to oversee elections on the island, for official designation as a political party and it was officially recognized by the provisional government. On 15 August 1908 the group held its first public meeting in the Plaza de Cristo in Havana.

En 1912 (Havana: Editorial de Ciencias sociales, 2002); Rafael Conte and José M. Capmany, Guerra de Razas (Negros contra blancos en Cuba), (Havana: Imp. Militar de Antonio Perez, 1912); Serafin Portuondo Linares, Los Independientes de Color: Historia del Partido Independientes de Color (Havana: Publicaciones del Ministerio de Educación, 1950).

${ }^{41}$ The PIC's platform of “Cuba for the Cubans” included demands for state assistance for all participants in the wars who wanted to return home but were financially unable to do so; opposition to the Platt amendment; revision of all legislation introduced under U.S. occupation; job preference for Cuban born over foreign-born; free education, including university; passage of child labor laws; workman's compensation; diplomatic posts for Afro-Cubans; non-selective immigration; penal reform; and opposition to the death penalty; see Ada Ferrer, Insurgent Cuba, 145-59.

${ }^{42}$ Estenoz, “Elección y Selección,” Previsión, 30 August 1908. 
The Agrupación's rallies during subsequent weeks were the talk of Havana, and the Cosmopolita's diners engaged in passionate conversations about the meaning of this new power group. That evening, at a table near Alberto Yarini's party sat the Interim Second Secretary of the U.S. Legation, George Cornell Tarler, newly arrived in Havana, along with Captain Granville Fortescue, aide to the supervisor of the rural police force and clerk of the American Legation. The two nursed their drinks and waited for the Norwegian minister, a Dr. Bronchorst, to return from purchasing one of the evening papers, before beginning their dinner in an adjacent dining room of the Hotel Inglaterra. ${ }^{43}$

Accounts of what happened next vary in details. Sometime after the arrival of Bronchorst, the group's conversation reportedly focused on denouncing Cubans with disdain for their "mixed" practices, recent racial developments on the island, and the formation of a political party of "the colored race." ${ }^{44}$ Tarler is said to have remarked that "the problem with this filthy country is that whites and blacks sit at a table together." To which one of the other two in his party responded that it did not seem strange to him since in Cuba even in "high society blacks are seen having intimate relations with young white girls.” ${ }^{45}$ Sensing the remarks were directed at his group because the Afro-Cuban General Salcedo sat with them, Yarini addressed the Americans in English, "politely"

${ }^{43}$ Yarini's deposition suggests that the English-speaking diplomats, given the rudeness of the comments and the large number of bottles on the table, were thoroughly drunk; ANC, Audiencia de la Habana, Yarini trial defense deposition, 31 October 1908, Legajo 224/10.

${ }^{44}$ Daily Telegraph, 23 September 1908.

45 ANC, Audiencia de la Habana, Yarini trial defense deposition, 31 October 1908, Legajo 224/10. 
asking them to cease their comments. The request reportedly only precipitated additional invectives and ridicule. This version of events was later disputed by Tarler, whose official report noted it was Fortescue who had merely commented that the group sounded [emphasis added] like the Agrupacíon de Color rallies which Havana police had broken up earlier that month for disturbing the peace. ${ }^{46}$

In any case, the Cubans—-most of whom did not speak English and probably had little knowledge of the topic of conversation—were quickly ushered out of the café by their host. A few minutes later, the 26-year-old Alberto Yarini, returned to the café, demanding satisfaction from the Americans. Although in his deposition Yarini later claimed self-defense, initial accounts reported he entered the café, tapped Tarler on the shoulder and before the latter could react, punched him in the face three times, rendering him almost, or—depending on the version—completely, unconscious. Tarler fell hard against one of the café's marble tables. Another Cuban who had followed Yarini into the Cosmopolita reportedly hurled a chair at Captain Fortescue, hitting him in the arm. A police officer patrolling the Acera quickly intervened and Yarini and his companions simply walked out of the café. ${ }^{47}$ The battered Tarler was taken to the First District Emergency Hospital where he gave the alias of "Samuel Smith" and a false place of

${ }^{46}$ For Tarler's account of the incident see G. Cornell Tarler correspondence to Secretary of State Elihu Root, 25 September 1908; U.S. of State Numerical and Minor File 1906-1910, no.14963, NARA II.

${ }^{47}$ Reports vary as to whether Yarini was alone or accompanied. The "heroic" versions have him confronting the Americans alone. The court deposition presented Yarini as asking for an apology and Tarler reinterating his opinion about the "malditos negros de este pais" after which he stood up in an arrogant and menacing posture which Yarini interpreted as the provocation of the fight that ensue; Yarini trial defense deposition, 31 October 1908, ANC, Legajo 224/10. 
residence at the "Hotel Sevilla." Along with a bruised eye and jaw, Tarler’s injuries included a broken nose and a laceration above his right eye about one centimeter long. ${ }^{48}$ After a quick review of the situation, Havana police arrested Yarini a short time later at his home on Paula Street in San Isidro and charged him with disturbing the peace.

The next morning, the daily El Comercio reported that Yarini had been arrested, but only after "thoroughly drubbing Tarler." ${ }^{49}$ The story noted that after leaving the Emergency Hospital, "the three Yankees [commented they ... .] would not file charges because they first must report the incident to Mr. Greble [Leuitenant Colonel Edwin St. John Greble].” Greble had served in Cuba during the first U.S. occupation (1899-1902) as U.S. disbursement officer for charities in Havana. ${ }^{50}$ He had returned to Cuba with the second U.S. occupation "advisor" to the Cuban government and Supervisor of the Department of the Interior and Supervisor of Police. ${ }^{51}$ In the closing sentence of the report the editor noted, "We presume [the Americans] will not complain to Mr. Greble that [in Cuba] one is not permitted to speak ill of Cubans. ${ }^{\text {"52 }}$ The story in that afternoon’s edition of The

${ }^{48}$ G. Cornell Tarler, Chargés de affair ad interim, to Justo García Velez, Acting Head of the Department of State, 14 October 1908; U.S. Department of State Numerical and Minor File 1906-1910, no.14963, NARA II. 1908.

49 “El escándalo de anoche en la Acera del Louvre,” El Comercio, 23 September

${ }^{50}$ U.S. Congress, Senate, Committee on Relations with Cuba, Statement of revenues and expenditures in Cuba: as shown in auditor's statement of accounts current in May and June, 1900, and supplementary accounts from date of American occupation to June 30,1900. (Washington, D.C.: Government Printing Office, 1902)

${ }^{51}$ The Pharmaceutical Era, 39, January 9, 1908, 57.

${ }^{52}$ El Comercio, 23 September 1908. Colonel E. St. J. Greble served as advisor to the Department of Government of Cuba from 1906-1909. 
Daily Telegraph was more elaborate and contained an English translation of El Comercio's “Angry Version,” followed with the exculpatory "True Version” of events in which Tarler was an innocent victim of misguided Cuban passion. ${ }^{53}$

The pro-Spanish, conservative newspaper Diario de la Marina was one of the few newspapers that did not report the incident at the Cosmopolita. Instead, three days later, on 25 September, its editor suggestively addressed the issue of race: "before the law, there is no difference among individuals, and [in Cuba] people of color enjoy the same rights in public places as do whites. No white Cuban would deny to extend a hand of friendship to a man of color ... no white Cuban will cease to honor the memory of the great revolutionary heroes of color ... nor to acknowledge the debt owed for their efforts in our independence. If compared with the treatment of Negroes in the United States, who can bring any complaint against white Cubans? ... We are pleased that almost every black man participates in our political struggles, inspired by the system of government and not by anthropological differences.” The editor closed the editorial citing that "the Cuban Republic, in order to exist with dignity (para subsistir dignamente), must be a labor of love, and not of hate, of harmony, not of passion, in short, the work of all Cubans." ${ }^{54}$ Yarini's arraignment on charges of disturbing the peace was held the day the story appeared; Tarler, claiming diplomatic privilege did not appear in court.

53 “Cornell Tarler Assaulted by Cuban Politician in Cosmopolitan Café,” Daily Telegraph, 23 September 1908; U.S. of State Numerical and Minor File 1906-1910, no.14963, NARA II.

54 “Deber de todos,” Diario La Marina, 25 September 1908. 


\section{Hegemonic Masculinity}

Interim Second Secretary Tarler arrived in Cuba in late August 1908, just a few weeks before the incident at the Cosmopolita. ${ }^{55}$ Single and thirty-two years of age, Tarler was a New York lawyer who lived on Broadway and whose comings and goings were reported in the society columns of the New York Times. ${ }^{56}$ The well-connected Tarler had

fervently sought an appointment as a member of the U.S. diplomatic corps. ${ }^{57}$ A graduate of Columbia University, Tarler held a number of degrees, A.M., M.S., Ph.D., and LL.B., and by 1908 had practiced law for nine years in New York. He also lived in Mexico for four years on some unspecified assignment-perhaps accompanying his father who had business in Mexico. Having taken the required examination for the diplomatic service, Tarler nevertheless found himself still without a permanent position as a diplomat. ${ }^{58}$ On 30 July 1908, he received notification that his exam grade was $62 \%$ and his deficiencies

55 Tarler arrived in Havana on 28 August 1908. Acting Secretary of State Alvey A. Adee correspondence to G. Cornell Tarler, 14 September 1908; U.S. Department of State Numerical and Minor File 1906-1910, no.14963, NARA II.

${ }^{56}$ See New York Times, 4 June 1909; and 13 June 1913.

57 G. Cornell Tarler to Elihu Root, 5 March 1909; U.S. Department of State Numerical and Minor File 1906-1910, no.14963, NARA II.

58 Tarler received his A.M. from Columbia University in 1901; see Catalogue of Officers and Graduates of Columbia University from the Foundation of King's College in 1754, (page 81 of 107), accessed 17 September 2010. Prior to sailing to Havana in 1808, Tarler requested all mail be sent to \#18 Gramercy Park, Columbia University Club; G. Cornell Tarler correspondence to Acting Secretary of State Alvey A. Adee, 14 August 1908; U.S. Department of State Numerical and Minor File 1906-1910, no.14963, NARA II. In a letter of recommendation for a promotion to First Secretary of the Havana Legation, from U.S. Representative, J. Van Vechtlen Olcott, Republican from New York's $13^{\text {th }}$ district and member of the House Committee on Naval Affairs, Olcott cites Tarler's educational credentials and his fluency in Spanish, French, and German; J. Van Vechtlen Olcott letter to the U.S. Secretary of State (no name), 14 December 1908; U.S. of State Numerical and Minor File 1906-1910, no.14963, NARA II. 
included international law, diplomatic usage, and translation from English to Spanish. Unable to pass the examinations which would grant him a full appointment, Tarler was informed by Acting Secretary of State, Robert Bacon, "the Department ... has decided to waive your deficiency in examination for the time being and you will be appointed as Second Secretary of Legation at Havana. ${ }^{59}$ His salary would be $\$ 1800$ per year to be drawn quarterly. ${ }^{60}$ Relunctantly, Tarler settled for the temporary post—pending a future re-examination—as a way to gain a foothold in the corps.

Delaying his departure for Havana numerous times during the following month, Tarler left New York via Atlantic Coast Lines on 24 August 1908 and upon arrival in Havana the following Saturday, he quickly claimed his first paycheck and requested moving expenses. ${ }^{61}$ Because the Havana Legation Secretary Edwin Morgan was anxious to travel to the U.S. on unspecified business, on Sunday, 29 August 1908, Tarler temporarily

${ }^{59}$ Robert Bacon correspondence to G. Cornell Tarler, 30 July 1908; U.S. Department of State Numerical and Minor File 1906-1910, no.14963, NARA II.

${ }^{60}$ Acting Secretary Alvey A. Adee correspondence to G. Cornell Tarler, 22 August 1908; U.S. Department of State Numerical and Minor File 1906-1910, no.14963, NARA II. The stipend also included five cents per mile for travel expenses which Tarler claimed on the day he arrived in Havana: New York to Havana via Knights Key, \$80.30. Tarler may have had limited funds at his disposal as he drew his pay monthly while at his post in Havana; G Cornell Tarler to correspondence to Secretary of State Elihu Root, 11 February 1909, advising of draft drawn for salary for the month of January 1909; U.S. Department of State Numerical and Minor File 1906-1910, no.14963, NARA II. Tarler claimed to have been recommended for positions by Senators Platt and Depew and Congressmen Bennet, Olcott, Parsons, "and others”; G. Cornell Tarler correspondence to Elihu Root, 5 March 1909; U.S. Department of State Numerical and Minor File 19061910, no.14963, NARA II.

${ }^{61}$ G. Cornell Tarler correspondence to Acting Secretary of State Alvey A. Adee, 24 August 1908 and "G. Cornell Tarler to Elihu Root, Secretary of State," 28 August 1908; U.S. Department of State Numerical and Minor File 1906-1910, no.14963, NARA II. 
replaced Morgan as U.S. Chargé d'affaires ad interim in Havana for about one month (at a much higher salary of about $\$ 500$ per month). Upon Morgan’s return to Havana in early October, Tarler resumed his post as Second Secretary. ${ }^{62}$

After copious letters and telegrams during the month of August in anticipation of his arrival in Havana and later regarding his pay, Tarler's next communication to Washington, D.C., came a month later on 25 September 1908, "I have the honor to inform you that I was assaulted by a Cuban.” In Tarler’s official report of the incident at the Cosmopolita of 22 September, he reported that "the assault was entirely unwarranted . .. it was the most brutal and cowardly act conceivable." ${ }^{63}$ He added he had wanted to avoid any publicity over the incident, but since the newspapers already had published several accounts, he felt obliged to bring the matter to the attention of Justo Garcia Velez, Cuban Acting Secretary of State, and Governor Charles Magoon. Tarler’s letter recommended the incident should hardly be considered "illustrative of a supposed unfriendliness held by the Cubans towards Americans here" and that his assailant's long criminal record indicated this was not a politically motivated attack. Attached to Tarler's

${ }^{62}$ G. Cornell Tarler correspondence to Elihu Root, Secretary of State, 29 August 1908, and “G. Cornell Tarler to Elihu Root, Secretary of State," 14 October 1908; U.S. Department of State Numerical and Minor File 1906-1910, no.14963, NARA II.

${ }^{63}$ Tarler's companion at the Cosmopolita that evening, Captain Granville Fortescue, had spent some time in Cuba with Teddy Roosevelt's Rough Riders during 1898, and a decade later, after resigning his Army post, served as an inspector with the Havana rural guard. Although raised in the Roosevelt clan and biologically a Roosevelt, Fortescue had not been able to capitalize on his connection because of his illegitimate status. Fortescue was wounded in action at San Juan Hill and served in the Philippines the following year. He resigned from the army in 1906 and served in the Cuban Rural Guard until 1909. In 1909, shortly after the incident at the Cosmopolita, Fortescue left Cuba for good; see U.S. Department of State Numerical and Minor File 1906-1910, no.14963, NARA II. 
statementt was a report of Yarini's criminal record "hurriedly" compiled by Colonel Greble and the Havana Secret Police. ${ }^{64}$ According to the report of Havana's Secret Police Chief, José Varona, “this man [Yarini] has a bad record and reputation.” The report to Greble, in English noted that Yarini, "since many years has been living without doing any work, devoting himself exclusively to exploit prostitutes, having three or four of them at a time, from whom he requests all the money they obtain from their immoral commerce.” The report continued, “[Yarini] is very aggressive and quarrelsome and for that reason, all the men and women of bad character are afraid of him.” Verona attached Yarini's criminal record adding that "this is not even fifty percent of the cases [in which he was involved because] most of his victims have refused to file a complaint against him, on account of his fame of guapo (bully), fearing his threats.” 65

Within two weeks, however, Tarler was requesting a different approval from Washington regarding the incident, no doubt buoyed by his colleagues' encouragement and his grandiose self-appraisal. "The foreign office has requested my declaration in the matter of the assault," he reported, "public opinion as well as colleagues are in favor of

${ }^{64}$ G. Cornell Tarler correspondence to Secretary of State Elihu Root, 25 September 1908; U.S. Department of State Numerical and Minor File 1906-1910, no.14963, NARA II. Also attached to the report were newspaper clippings of stories about the incident in Havana newspapers on 23 September, including the Daily Telegraph, Havana Post, and El Comercio.

${ }^{65}$ José Varona, Chief of the Secret Police official report to Lt. Col. E. St. J. Greble, Supervisor of Police, 24 September 1908; U.S. Department of State Numerical and Minor File 1906-1910, no.14963, NARA II. 
prosecution of assailant even though unofficially." ${ }^{, 66}$ The next day, U.S. Secretary of State Elihu Root's telegram to Tarler indicated the Second Secretary was authorized to waive his diplomatic immunity as long as he testified by deposition and not in person with a warning that "any appearance of personal interest in the prosecution of the assailant should be excluded.” On 14 October, Tarler provided Cuban authorities with his deposition so more serious charges would be filed against Yarini. ${ }^{67}$ Tarler’s next report noted it was very likely the injury to his right eye would be permanent and he had been under a doctor's care since the "brutal, cowardly, and absolutely unprovoked" attack. ${ }^{68}$ Tarler would work diligently to validate his opinion of Yarini to U.S. authorities.

Yarini was active in Havana politics and backed the newly-organized Conservative Party, serving as president of the party's San Isidro precinct. In that role, he represented the lowest rungs of Havana’s social classes who held significant popular political capital and influence even with the franchise restrictions of the Republic. Disappointed with the Liberal Party gains in the August provincial elections, Yarini was immersed in the preparations for the November national elections that promised to elect a Cuban President

${ }^{66}$ G. Cornell Tarler correspondence to Secretary of State Elihu Root, 6 October 1908; U.S. Department of State Numerical and Minor File 1906-1910, no.14963, NARA II.

${ }^{67}$ G. Cornell Tarler correspondence to Secretary of State Elihu Root, 15 October 1908; U.S. Department of State Numerical and Minor File 1906-1910, no.14963, NARA II.

${ }^{68}$ Secretary of State Elihu Root correspondence to G. Cornell to Tarler, 7 October 1908; U.S. Department of State Numerical and Minor File 1906-1910, no.14963, NARA II. 
and restore Cuban self-rule after U.S. occupation ended in 1909. It was generally believed that Yarini was positioning himself to run for the Cuban Congress and aspired to the presidency. At the Cosmopolita, the Americans had denigrated his choice of friends and the Cuban sense of equality and fraternity. Something had to be done and Yarini responded as any Cuban man was expected to do when his friends' (and by extension his country’s) honor was challenged.

The status of the final charges against Yarini was delayed because of the diplomatic implications of the case. After the incident at the Cosmopolita, Yarini was first arrested for disturbing the peace and quickly released on bail, given Tarler's misrepresentation as Mr. Smith and his status as ad interim, which did not carry the severity of prosecution had he been fully U.S. minister to Havana. On 29 October Morgan received an answer from the Supervisor of the Department of State and Justice in Cuba, E.H. Crowder, containing his legal opinion: the term “'Minister' is defined to be anyone invested, even temporarily, with functions and duties of ministers. The statute applies to the case you presented of the assault upon the Secretary of the Legation.” After a month of discussions of the legal and honorable implications of the attack, Crowder recommended the case be transferred from the lower Correctional Court, where the disturbing the peace charge would be heard, to the Audiencia "with a view to a formal trial and indictment." Under Article 151 of the Cuban Penal Code, assault on a duly appointed minister of a friendly government was deemed delito contra el derecho de gentes (human rights violation) and was punishable by “correctional imprisonment” for a period of four years two months and one day (according to Article 60 of the Penal Code), and payment of 
court costs; imprisonment prior to trial to be deducted from any sentence. If convicted, Yarini would also be made to pay Tarler 500 pesetas (\$100 US) in damages, in default of which he would have to serve additional imprisonment pro-rata. Crowder added that such cases had a lengthy process, but that he would try to expedite this one through the courts. ${ }^{69}$ On 31 October 1908, Yarini was formally charged before the Audiencia and promptly released on $\$ 500$ (pesos) bail and a surety of 500 pesetas as guarantee against a possible fine. ${ }^{70}$ Two weeks later on 12 November 1908 an indictment was returned against Yarini by the Audiencia. ${ }^{71}$

With the wheels of justice grinding slowly and Cuba's November presidential elections taking up all of the government's attention, in early November Tarler telegraphed Root asking that he be considered for reexamination "with the view of being transferred to the post of Secretary of [the Havana] legation”; Morgan was scheduled to leave Cuba for another post. ${ }^{72}$ Not hearing the usual instant response from Washington, Tarler again petitioned Root three weeks later, this time requesting a "short leave of absence" for the month of December citing that legation Secretary Morgan had approved the leave. His leave was granted on 4 December and Tarler set sail for New York three days later.

${ }^{69}$ E. H. Crowder correspondence to Edwin Morgan, 29 October 1908; U.S. Department of State Numerical and Minor File 1906-1910, no.14963, NARA II.

${ }^{70}$ Opinion filed 12 November 1908, Juzgado de Instruccion del Distrito Centro, Causa \#1070/908, ANC, Audiencia de la Habana, Legajo 224/10.

71 “Indictment is returned against Alberto Yarini,” Havana Telegraph, 13 November 1908.

${ }^{72}$ G. Cornell Tarler correspondence to Elihu Root, 5 November 1908; U.S. Department of State Numerical and Minor File 1906-1910, no.14963, NARA II. 
Tarler spent the month of December 1908 in New York, no doubt regaling New York socialites with his adventures in Havana.

On 22 December, while in New York, Tarler received word that his re-examination, originally scheduled to be available to him in Havana, would be administered in Washington, D.C. on 4 January 1909 and his leave was extended until that time. ${ }^{73}$ Tarler's preoccupation with his salary was humorously addressed in the State Department's last communication to Tarler for 1908: he was informed that because diplomatic corps' appropriations were exhausted, he could not collect his pay as Chargés d'Affaires ad interim for December and that hopefully Congress would allocate additional funds for the coming year. ${ }^{74}$ Tarler nevertheless continued to prepare for his re-examination in January, which he passed, and a month later, on 9 February 1909, arrived in Havana again, still as Second Secretary of the Legation. He quickly drew a draft for his salary of $\$ 150 .^{75}$

In Havana, as José Miguel Gómez, who had been victorious in the November elections, was preparing to take the oath of office as President of a second Cuban republic at the end of January 1909, on 13 January, two months after Yarini's indictment, the Audiencia

${ }^{73}$ Acting Secretary of State Alvey A. Adee correspondence to G. Cornell Tarler, 22 December 1908, U.S. Department of State Numerical and Minor File 1906-1910, no.14963, NARA II.

${ }^{74}$ Acting Secretary Alvey A. Adee correspondence to G. Cornell Tarler, 31 December 1908; U.S. Department of State Numerical and Minor File 1906-1910, no.14963, NARA II.

${ }^{75}$ G. Cornell Tarler to Robert Bacon, 9 February 1909; U.S. Department of State Numerical and Minor File 1906-1910, no.14963/30, NARA II. 
set a trial date for March. The reaction in Havana to the filing must have been very antiTarler, as within two weeks of Tarler's return to the city, the diplomat was requesting a transfer to Mexico citing the Cuban “climate” was "extremely detrimental to [his] health.” Changing his story from the previous fall, in his communication Tarler reported his health was the true reason he had requested leave the previous November, “for the purpose of consulting my physician as I have been feeling rather poorly since I had been in Havana.” He added that his sojourn in New York had done him a world of good and that Havana’s climate was "undoubtedly detrimental” to his health. ${ }^{76}$ The request was followed with a letter of support from Tarler’s old acquaintance, U.S. Representative J. Van Vechtlen Olcott, Republican from New York's $13^{\text {th }}$ district and member of the House Committee on Naval Affairs, recommending Tarler for a post as Second Secretary in Mexico that had recently become available. ${ }^{77}$ Despite his Washington connections and the Representative's urging, a week later Tarler received the disappointing news that the position in Mexico had been filled. ${ }^{78}$ In March, things went from bad to worse for Tarler.

As scheduled, Yarini's trial for human rights violations, as outlined in the Reciprocity agreement of 1903 between Cuba and the United States, was heard before Magistrate

${ }^{76}$ G. Cornell Tarler correspondence to Secretary of State (no name), 20 Feb 1909; U.S. Department of State Numerical and Minor File 1906-1910, no.14963/33-36, NARA II.

77 J. Van Vechtlen Olcott correspondence to Robert Bacon, 24 February 1909; U.S. Department of State Numerical and Minor File 1906-1910, no.14963, NARA II.

78 Robert Bacon correspondence to G. Cornell Tarler, 27 February 1908; U.S. Department of State Numerical and Minor File 1906-1910, no.14963, NARA II. The post was filled by Thomas Ewing Dabney, Bacon to Olcott, 2 March 1909; U.S. Department of State Numerical and Minor File 1906-1910, no.14963/38, NARA II. 
Eduardo Azcárate of the Audiencia of Havana on 1 March 1909. Court Proceedings \#6895 of the Central District's municipal court recorded the charge as "lesion against the U.S. Chargés d' Affaires" citing that in Morgan's absence, Tarler was the acting minister of the Legation on the day of the assault and thus the incident required the more serious charges. ${ }^{79}$ The defendant was represented by "ex-Senator" Carlos Fonts Sterling, of the Fonts and Moré law firm in Havana, who had been a spokesperson for Palma’s Moderates in the U.S. press in $1906{ }^{80}$ His participation in the trial only added to popular attention and curiosity. In the pre-trial motion, Fonts listed ten witnesses for the defense, four of whom had not been listed in Tarler's complaint: Arturo Plana, General Salcedo, Coronel Silva, and Juan Antonio Gobel..$^{81}$

The trial was held as scheduled in the Audiencia chambers on 1 March 1909. Tarler was represented by a public defender provided by the Cuban government, identified as Gutierrez Fernandez. ${ }^{82}$ Fortescue, Tarler's chief witness, did not appear in court as in

${ }^{79}$ ANC, Audiencia de la Habana, Legajo 224/10. "Delito contra el derecho de gentes, 13 Enero, 1909.”

${ }^{80}$ Carlos Fonts y Sterling, a member of Palma's Moderate party,served as government Auditor and in the Cuban Senate during the Palma administration. Fonts had been in New York vacationing when the 1906 insurrection broke out; "Amnestry Fails to End the Rebellion,” New York Tribune, 25 August 1906; "Cubans Flocking Home: Alarmed by Insurrection, Hasten to Protect Interests,” New York Times, 28 August 1906; and Brooklyn Daily Eagle Almanac, 1906 (The Brooklyn Daily Eagle). In 1914, Fonts was a lawyer with the Havana Railway Company. Frederick Nicholas, ed., McGraw-Hill Electric Railway Manual: The Red Book of American Railway Investments, \#21 (New York: McGraw Publishing, 1914.)

${ }^{81}$ Deposed witnesses included the alleged victim, G. Cornell Tarler, Granville Fortescue, Officer Juan Iglesias, Frank Rosenhaus and Nicolas Bowler. ANC, Audencia de la Habana, Legajo 224/10.

82 “Decision in Tarler Case Awaited Today,” Havana Post, 3 March 1909. 
the time since the incident the previous fall he had left for the United States (and never returned to Cuba). ${ }^{83}$ At trial, all four of the defense's "surprise” witnesses appeared to testify. Their testimony, largely damaging to Tarler's case, may have rattled the American Tarler whose lawyer had trouble substantiating the events of the alleged assault. In an interesting development, also missing from court were the two Afro-Cuban war officers whose presence had reportedly precipitated the altercation in the Cosmopolita: Salcedo and Silva. No explanation was given about why, although subpoenaed, they would not testify. The hearing lasted a mere two hours after which the judge retired to consider a verdict.

\section{The American}

Tarler quickly penned an account of the hearing in an official report to Washington that provided the victim's interpretation of the proceedings. He reported "the prosecuting attorney [public defender Fernández], in addressing the court, expressed his regret at being obliged to accuse Yarini,” who, he believed, had acted "under the impulse of just indignation caused by the remarks of the Americans.” For the record, Fernandez noted, he would nevertheless perform "his duty." 84 The next day, La Discusión published a play by play of the trial: Yarini’s confession was admitted into evidence; Tarler did not appear, claiming his diplomatic privilege and instead provided a deposition; Fortescue did not appear, as he had left for the U.S.; police officer Juan Iglesias testified he heard

83 Edwin Morgan correspondence to Elihu Root, 4 March 1909; U.S. Department of State Numerical and Minor File 1906-1910, no.14963, NARA II.

${ }^{84}$ Edwin Morgan correspondence to Elihu Root, 4 March 1909; U.S. U.S. Department of State Numerical and Minor File 1906-1910, no.14963/39-47, NARA II. 
the commotion at the Cosmopolita but saw nothing except the aftermath; Habaneros Carlos Levy and Juan Gobel testified they were dining in the café and stepped in when one of the Americans picked up a chair with the intention of hurling it at the Cubans; Frank Rosenhaus, a Russian-born U.S. citizen, testified he had never seen the accused before the trial, and, although he was employed at the U.S. Legation as a clerk, he was just passing by the café on that evening, and could provide only hearsay testimony of the events (as told by Tarler); Nicolas Bowler, a Cuban citizen originally subpoenaed by Tarler, testified the Americans at the café were verbally denigrating Cubans and he clearly heard Yarini ask the "yanquis" to stop their tirade. He added that when the fight broke out, he had to physically restrain the Americans until the police arrived. The paper also reported that the defense attorney was sublime (elevado) in his oration. FontsSterling's arguments not only were effective, Tarler complained, but also "saturated with patriotic phrases,” asking that Yarini's case before the tribunal be dismissed or remanded to a lower court. ${ }^{85}$

Two days later, on 3 March 1909, Audiencia Judge Azcárate rendered his decision. The case would be remitted to a lower court "on the grounds not only that [Yarini] was ignorant of Mr. Tarler's diplomatic identity but that when the latter was taken to the emergency room to have his wounds treated, he waived his official rights by giving the name 'Samuel Smith.’”, 86 The story made headlines in Havana’s afternoon papers. Perhaps anticipating the official recording of the judgment, Tarler wrote former Secretary

85 “El Proceso de Yarini, agresión a un diplomático americano - El juício oral,” La Discusión, 2 March 1909.

${ }^{86}$ Havana Telegraph, 3 March 1909. 
of State Elihu Root congratulating him on his recent election as Senator for New York. In his letter, Tarler name dropped about their mutual acquaintances, citing a meeting with Root four years prior and adding his request for help in securing a diplomatic post in Europe-concluding the letter with "awaiting your favor..."

The next day, on 6 March, the Audiencia’s findings were officially recorded and charges against Yarini were dropped; the case remitted to a lower tribunal, to be tried as simple battery, "unaffected by the diplomatic character of the complaint”; Tarler had effectively waived his rights by giving a false name when interrogated by authorities at the Emergency hospital, and the injury was considered minor since it had healed within 30 days, which Tarler vehemently disputed. ${ }^{87}$ It was expected the lower Correctional Court would hear the case before the end of March and Tarler's superiors suggested he should hire his own attorney; Tarler was on his own if he wanted to pursue the case in the lower courts. ${ }^{88}$ Secretary Morgan offered little redress for Tarler; "Although it is necessary to afford Mr. Tarler every assistance in order that he may obtain justice,” he wrote, "it would appear the responsibility for securing his protection and justification [however] rests upon the Cuban government.” 89

87 Sentence \#71, 6 March 1909. Licenciado Pascual de Rojas y Pineiro, Secretary, Criminal Division, Audiencia de la Habana. Page 385, Record of Sentences for 1909, ANC, Audiencia de la Habana, Legajo 224/10.

${ }^{88}$ Edwin V. Morgan correspondence to Secretary of State Philander C. Knox, 9 March 1909; U.S. Department of State Numerical and Minor File 1906-1910, no.14963, NARA II.

${ }^{89}$ Edwin Morgan correspondence to Elihu Root, 4 March 1909; U.S. Department of State Numerical and Minor File 1906-1910, no.14963, NARA II. 
Trying to clear his name, or perhaps seeking help with attorney's fees, on 11 March Tarler sent a lengthy, exculpatory letter to Secretary of State Philander Knox providing a seven-fold "further justification" of his actions to the new Taft administration. Tarler cited the permanent nature of his injury and included a copy of the examination by Dr. Carlos Finlay, University of Havana professor and scientist who for many years worked on the etiology of yellow fever. He protested his injuries had not healed in 30 days as cited in the court proceedings and that they still caused him problems. Tarler also tried to clear his name by denying the topic of conversation that precipitated the fight at the Cosmopolita was racially motivated. He protested "Yarini never asked [them] to stop," complained that he had been assaulted from behind while seated and without warningsince he was closer to the door than Fortescue; defended himself against the accusation of being drunk since they had only been in the restaurant 20 minutes; and related the prosecuting attorney’s reluctance to prosecute. He ended his letter noting Yarini’s political connections had saved the Cuban from prosecution: "The rumored political support of my assailant may find some justification in the fact that of the numerous indictments found against him for grave offenses ... he has, with the exception of one or two cases, escaped punishment. ${ }^{90}$

${ }^{90}$ G. Cornell Tarler correspondence to Philander Knox, 11 March 1909; U.S. Department of State Numerical and Minor File 1906-1910, no.14963, NARA II. Tarler's report included a letter dated 29 October 1808 from Carlos Finlay, Professor of Eye Diseases at the University of Havana, confirming Tarler's injury had not healed completely in 30 days. The report noted Tarler suffered slight chronic congestion of the eye with slight blurring of disk margins and slight circumpapillary retinal edema of the right eye. His visual acuity was slightly impaired and could not be improved by glasses. The diagnosis: "slight retinal edema of the right eye with some diminution of vision probably due to the injury received one month ago (Sept 22).” 
An appeal was considered, no doubt at Tarler's request, and on 13 March, Morgan made a formal request to the Cuban government that an appeal to the Supreme Court be granted based on the Amnesty Act. The reason for proceeding with a new trial was rather curious. Secretary Morgan had consulted privately with Havana lawyers and had been advised that an appeal would allow Tarler to be better represented in order to "place himself in a favorable light before the Cuban public" which was inclined to believe Tarler made the remarks at the Cosmopolita, adding the "Legation [considered] itself bound to defend a member of its staff to the extent of its power.” A short reply from Washington urged Tarler to hire private counsel and prosecute. ${ }^{91}$

It is unclear what may have ensued during the next few weeks in March and April, but on 11 May, Tarler once again solicited Washington, for transfer to any post-anywhere. In another letter dated the same week, on 14 May Tarler added a footnote to his request, citing his continuing ill health and the detrimental Havana climate-it may have been not only a question of the weather for Tarler at that point, but also of the growing popular animosity to which he was subjected. Two weeks later he was granted leave to return to the U.S. with a notation added at the bottom of the communication, "Tarler will not return to Cuba."92 On 2 June 1909, resigned the case was dead and his reputation in

${ }^{91}$ Acting Secretary of State Huntington Wilson correspondence to G. Cornell Tarler,15 March 1909; U.S. Department of State Numerical and Minor File 1906-1910, no.14963, NARA II.

92 Philander Knox correspondence to Robert Morgan, 27 May 1909; U.S. Department of State Numerical and Minor File 1906-1910, no.14963, NARA II. 
Havana unsalvageable, Tarler left Cuba for New York City. His departure was duly reported in the New York Times. ${ }^{93}$

Once back in New York City, Tarler continued to work his connections to get a new diplomatic post. In August, still using Havana legation stationery which meant he was continuing to draw his salary as second secretary, he accepted a diplomatic post to Siam, ostensibly as part of Secretary Knox's shake up of the foreign service corps. ${ }^{94}$ The occurrences in Havana were no doubt heavily considered in Knox's realignment of the department. After several months of paperwork, including obstructions to taking the oath of office until he received a letter from his doctors and guarantee that "the trouble that disqualified [him] from performing [his] duties” had abated, by October 1909, a little over a year after his arrival in Havana, the diplomatic register listed Tarler’s appointment to the Legation in Bankok, Siam. He set sail for Siam on 11 December 1909, still as a Second Secretary. ${ }^{95}$

93 “G. Cornell Tarler Coming Home on Leave,” New York Times, 4 June 1909; Robert Morgan correspondence to Philander Knox, 1 June 1909 and Robert Morgan to Philander Knox, 2 June 1909; U.S. Department of State Numerical and Minor File 19061910, no.14963, NARA II.

94 “Knox Makes More Changes; This Time He Turns His Attention to UnderSecretaries of Foreign Service.” New York Times, 1 August 1909; and G. Cornell Tarler Correspondence to Acting Secretary of State Alvey A. Adee, 10 August 1909; U.S. Department of State Numerical and Minor File 1906-1910, no.14963, NARA II.

${ }^{95}$ Philander Knox correspondence to American Minister to Bangkok, Hamilton King, Esq., 29 November 1909; U.S. Department of State Numerical and Minor File 1906-1910, no.14963, NARA II. Tarler received a \$200 raise per year in his new post, The World Almanac and Book of Facts, (New York: Newspaper Enterprise Association, 1909) 628. By 1913, Tarler had been promoted and served as Secretary of the Embassy in Constantinople. "Diplomat Here for Wedding," New York Times, 13 June 1913. When the U.S. entered WWI, the Ottoman Empire severed diplomatic relations with the U.S. 


\section{The Cuban}

During the months after the decision of the Audiencia in the Tarler case, Alberto Yarini, who had been publicly quiet during the seven months of proceedings, continued his trajectory as the rising star of the new Conservative Party, perhaps aided in part by his "heroic and patriotic” display in defense of Cuban honor. The Conservatives needed a champion and a way to attract the popular vote. The reports of graft and bribery by party leaders were widespread as the Conservatives used their resources to buy up government appointments, especially among the police force, during the U.S. occupation. It was reported that there was always bail available for petty offenses, first aid and doctors' services were offered free of charge and, short of that, "there were cigars and a pat on the back for everyone."96 Yarini’s newly enhanced reputation as a "hero and patriot,” genteel family connections, influence in San Isidro, and business ventures (prostitution and bolita) made him an ideal candidate for leadership in the new party. Yarini’s influence, however, went well beyond San Isidro. After the incident at the Cosmopolita, he became indispensible to the Conservative Party seeking elected office in the next national elections.

and Tarler was transferred yet again J.C. Hurewitz, The Middle East and North Africa in World Politics: A Documentary Record. British-French Supremacy, 1914-194, (New Haven, CT: Yale University Press, 1979), 97. By late 1917, Tarler was serving as Secretary to the Embassy in Rio de Janeiro (at a salary of \$2625 p/a) and once again working under Morgan (whose salary as Ambassador was \$17,500). Chicago Daily News Almanac and Yearbook (Chicago: The Chicago Daily News, 1918), 261.

${ }^{96}$ Cañizares, San Isidro, 50-51. 
Yarini's private personality only added to the allure. He did not speak publicly often, being a quiet and reserved man, but he was not reticent to "correct" in private or to defend those wrongly accused. The Conservatives used his physical charm and charisma to their advantage. The Party leaders reportedly bought Yarini a sumptuously appointed saddle for his legendary white steed. ${ }^{97}$ Yarini would often send his horse ahead of a meeting in the townships surrounding Havana piquing anticipation of his arrival. He would arrive with his entourage, mount his horse, and lead the procession through the main streets of outlying towns to the amazement and delight of the rural voter; a not-sodifferent display as that which accompanied the installation of Marti's statue in Havana in 1905.

The Acera de Louvre aristocrats also idolized the "patriot" of El Cosmopolita; women, attracted by his reputation and good looks, jockeyed to attend one of his barrio's political meetings; blacks looked to him as a true "partner and friend"; white orilleros identified with the rich and distinguished chulo who lived down the street from them in Paula; and the poor were always sure of a real (dime) or two. The Conservatives could take care of marshaling the "respectable" voters left. Victory was all but in the bag for the next Presidential elections and the Conservatives saw their way clear to oust José Miguel Gómez, nicknamed "the shark," whose administration had become notorious for its graft and corruption. In contrast, if not altogether true, Yarini's reputation as an honorable man and padrino (godfather) who helped anyone in need was becoming legendary in

${ }^{97}$ Depending on the storyteller, the horse, was either given to him by his mother, or purchased as a political tool by the Conservatives for $\$ 1500$. Cañizares, 38 and “Testimony of Federico Morales Valcárcel to Dulcila Cañizares” from interviews 19681971, Cañizares, San Isidro, 53-54. 
Havana. How much that generosity was fueled by Conservatives' coin is difficult to ascertain.

Yarini's political star continued to rise. At the end of August 1910, Yarini led a group of Conservatives stumping in the nearby town of Güines. The Havana Electric Railroad had opened a line to the town in 1905 and the township's votes would be important in the elections. About sixty or seventy Conservative supporters gathered to welcome the train from Havana and the group posed for a photo at the train depot when the local mounted police allegedly accosted a mulato member of the group. Within a few minutes a loud signal was fired outside the town limits and the Conservative gathering was reportedly ambushed by a group which was hiding, waiting for the signal. The altercation grew to a violent brawl with several shots fired. Yarini, in the middle of the mêlée was arrested and charged with disturbing the peace. He was held in the Güines jail for about a week before the Conservatives were able to negotiate a $\$ 1000$ bail. It was reported the altercation was a Liberal plot, aided by the police, to silence the Conservatives and Yarini in particular. It backfired and once again, however, Yarini’s bravery was reported; he was in the middle of the disturbance even knocking out two of an attacker's teeth—a different technique than used by the Yarini family of dentists. The play by play and subsequent testimony was reported (with photographs) by the Conservative’s La Discusión the next day noting a trial would be held later in the year. ${ }^{98}$ By the fall, Yarini was the undisputed darling of the Conservative press, influential in Havana politics, and regarded as a leader

98 The newspaper description of the incident at Güines and the transcript of the subsequent charges is cited by Cañizares, 121-128. See fanciful interpretation of the event in León ardo Padura Fuentes, El Viaje Mas Largo (Havana: Ediciones Union, 1994), 168. 
and champion of the people. Popular opinion was that Yarini was charismatic, generous, and respected; his boasted solidarity with the lower classes and broad support across all classes in Havana, catapulted him to prominence within his Party.

On the evening of 19 November 1910, Yarini took part in the Conservative Party's celebration of its first significant political victory: Ambrosio Hernández y Montalvo, President of the Conservative committee of the Arsenal district, had been elected to the City Council. The celebrations that evening included a procession through the Arsenal barrio streets accompanied by music from the fire department band. It was an impressive impromptu pageant as Conservative sympathizers on "spirited steeds” rode alongside the revelers; throughout the route fireworks lit the sky and Cuban flags decorated the balconies. Winding its way through the streets until it reached the home of Hernandez, the procession was led by Conservative leaders including "the beloved correligionado and untiring warrior, Alberto Yarini." ${ }^{99}$ The account of the festivities was published the day before Yarini's political career would end. (For a chronology of events, see Table 5: Timeline of Yarini-Tarler Case. )

\section{Conclusion}

Anthropologists argue that masculinity, like other classifiers of society, provides specific social status. Cubans were certainly not exempt from this overarching symbolism. ${ }^{100}$ At

${ }^{99}$ Diario de Cuba, 21 November 1910.

${ }^{100}$ Adding layer upon layer, the incident at the Cosmopolita coincides with the beginning of a racial stereotype shift in Cuban society that lasted through 1912 and the 
the Cosmopolita, the U.S. views of Jim Crow and social Darwinism had been called up in defining the nascent and conflicting identities of cubanidad. For Tarler, masculinity proved elusive, he was carried away from the fray semi-conscious, then lied about his identity, and ran away from his post. Perhaps to Tarler that was unimportant because Cubans were far beneath him; his assignment to Havana was below his status; and his opponent was, after all, a criminal, and, as such, a fitting example of the barbarism of cubanidad.

Some Cuban intellectuals and politicians of the time argued that "Cuban fraternity, forged during the independence struggle was or should be based on blacks’ recognition of the great sacrifices whites had made to liberate them.”101 Perhaps it was a similar motivation that prompted Yarini to "defend" his Afro-Cuban companion at the Cosmopolita as virtú confronted fortuna and the white man's burden was hoisted in defense of honor. Perhaps it was a more calculated political move. Whatever the motivation, Yarini acted out his masculinity in belligerent terms, as the protector of Cuba and of his people, standing up to the perceived imposition of a U.S. hegemonic world view of cubanidad.

bloodshed of the Race War: the shift from the popular conception of black men as socially marginal brujeros to a definitive-if criminal- expression of masculinity, as rapists. This short-lived phenomenon in Cuba mirrors the expressions of racial unrest the Partido Independiente de Color engendered. See Aline Helg, "Black Men, Racial Stereotyping, and Violence in the U.S. South and Cuba at the Turn of the Century," Comparative Studies in Society and History 42, no. 3 (Jul., 2000): 576-604.

${ }^{101}$ Alejandro de la Fuente, "Race, National Discourse, and Politics in Cuba: An Overview,” Latin American Perspectives 25, no. 3 (May 1998): 46. 
TABLE 4

\section{Timeline of Yarini -Tarler Case}

1908

July 30 Tarler Appointed Second Secretary of the U.S. Legation in Havana

August 24 Tarler arrives in Havana

September 21 Incident at El Cosmopolita

22 Yarini arrested on charge of disturbing the peace; released on bond

October 14 Tarler deposition given; calls for more serious charges be filed for Yarini for attacking a diplomat

31 Yarini formally charged with human rights violations for assault of a diplomat

November 12 Yarini indicted by the Audiencia; arrested and released on bond

14 José Miguel Gomez elected president

December 4 Tarler sets sail for NYC on leave

\section{9}

January 28 Second U.S. occupation of Cuba ends; Gomez installed as president

13 Audiencia sets trial date in Yarini case for 1 March

February 9 Tarler returns to Havana

24 Tarler requests transfer to Mexico

March 1 Yarini case heard before the Audiencia

3 Audiencia refuses to rule on the case and remands case to lower court

May 11 Tarler requests transfer - to any post

June 2 Tarler leaves Cuba for NYC with no reassignment

October Tarler appointed Second Secretary to the U.S. legation in Siam

December Tarler sailed for Siam 


\title{
CHAPTER VI
}

\author{
“NUNCA OLVIDARÉ AQUEL ENTIERRO” \\ MOURNING, PUBLIC SPACE, AND CUBANIDAD
}

"Not since the funeral of [Máximo] Gómez [had] Havana witnessed such tremendous demonstration of popular sympathy and respect as that which attended the funeral of Alberto Yarini [y Ponce de León ].”2 On 24 November 1910, thousands of spectators lined the sidewalks as the funeral procession made its way through Havana's main boulevards, many joining the cortege as it passed by. Led by a police escort and the city's chief of police, the procession included a band playing a somber cadence setting the pace for the mourners' amble. ${ }^{3}$ Behind them came the hearse, drawn by eight plumed horses, each draped in the yellow and black finery of the city's elite Caballero funeral establishment. ${ }^{4}$ Yarini's father and brother, dressed in appropriate mourning clothes, solemnly followed the young man's coffin as men jostled in the street demanding to carry

${ }^{1}$ Cañizares, San Isidro, 1910, 198.

${ }^{2}$ Ibid., 187-200; Tampa Tribune, November 25, 1910. Irene Wright described the funeral of Gómez in much the same terms as news accounts described Yarini's cortege. Wright, 78-79. For varying descriptions of Yarini's funeral procession, see La Lucha, 24 November 1910; Diario de la Marina (Havana), 25 November 1910; New York Times, 25 November 1910; and Washington Post, 25 November 1910. The Tampa Tribune carried the story of the viewing on 24 November 1910 and the next day offered coverage of the funeral. See also Fernández-Robaina, Recuerdos secretos de dos mujeres públicas, 40

${ }^{3}$ Fernández-Robaina, Recuerdos secretos, 39.

${ }^{4}$ Wright, Cuba, 78-79. 
the bier on their shoulders. ${ }^{5}$ Next came four wagon loads of flowers followed by a procession of several thousand (one estimate calculated the crowd at more than 20,000), including delegations from Havana's various political and commercial organizations. ${ }^{6}$

${ }^{5}$ Yarini's mother was noticeably absent from the group and Consuelo la Charmé, a contemporary prostitute, noted her absence; Fernández-Robaina, Recuerdos secretos de dos mujeres públicas, 39. Irene Wright wrote that Cuban women did not attend funerals as it was not acceptable conduct in "good society." Wright, Cuba, 45.

${ }^{6}$ The population of Havana province was estimated at 538,000 in 1907 while that of the island was 2,048,980; José L. Luzón, Economía, población y territorio en Cuba 1899-1983 (Madrid: Ediciones Cultura Hispánica del Instituto de Cooperación Iberoamericana, 1987), 83. 
More than 100 carriages, carrying representatives of the best society in the city, government officials, dignitaries, and officers from the army and navy ascended the knoll known as "El Bosque" on the road to the Cementerio Colón. It was reported that President Jose Miguel Gomez was in one of the lead carriages. Also in the throng, that inched its way along Galiano Street were "all the elements of the red light district ... gaudily attired women,” and members of "vodoo societies.”7 One observer noted he would never forget that funeral. ${ }^{8}$

${ }^{7}$ For descriptions of a Cuban viewing, funeral, and burial, see Irene Wright, Cuba, 43-48; and Bradley, Havana: Cinderella’s City, 400-402.

${ }^{8}$ Cañizares, San Isidro, 1910, 198. 
Figure 10

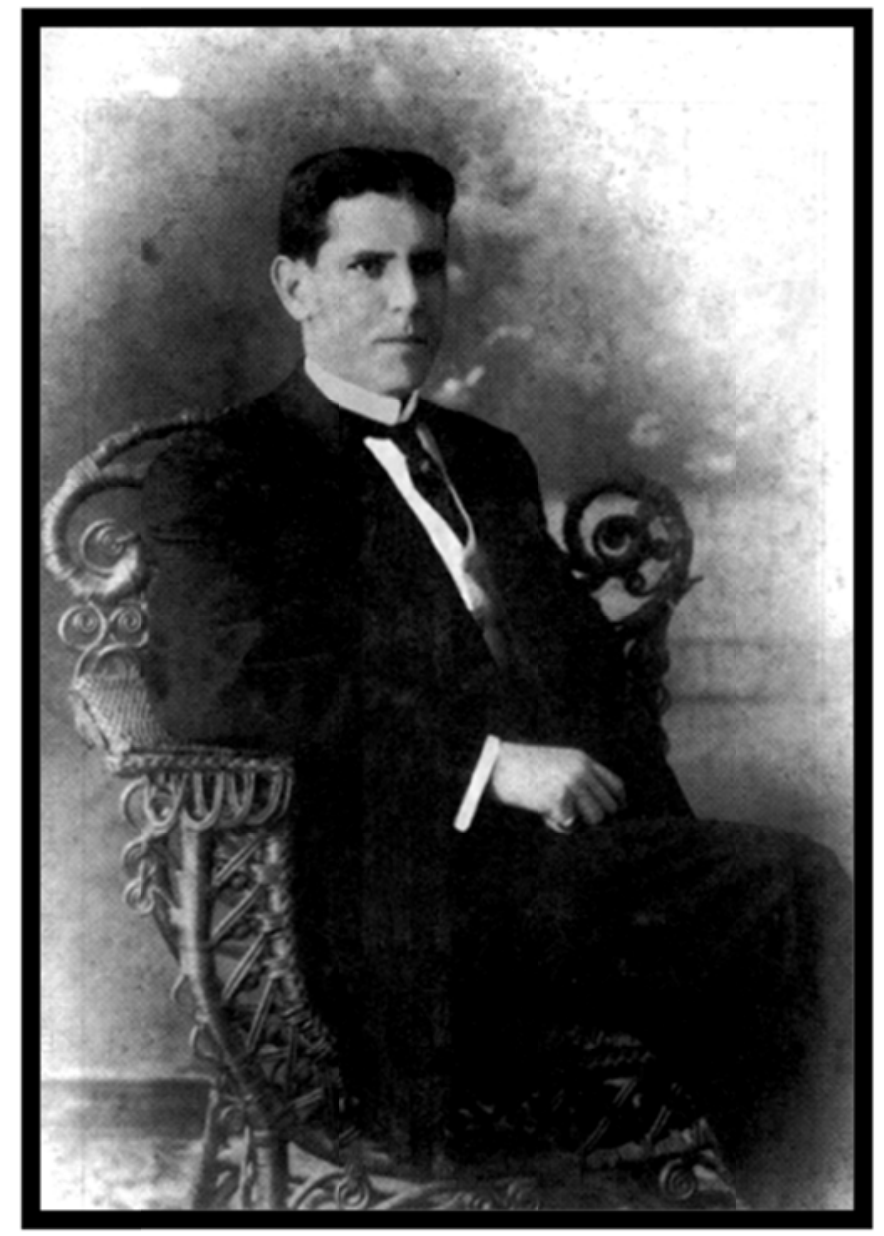

Photograph of Alberto Yarini

La Lucha, 24 November 1910.

The corpse being honored by such an outpouring of sympathy was not that of a caudillo de independencia and the procession was not another state funeral crafted by elites to instill national pride in their nation-building efforts. It was a spontaneous public expression of grief for a charismatic, 28-year-old aspiring politician who was also a notorious Havana chulo. 
The spectacle must have been impressive as coverage of Yarini's funeral was picked up by the Associated Press and featured on the pages of U. S. metropolitan dailies the day after Thanksgiving 1910. The headlines of The New York Times, the Tampa Tribune, and the Washington Post heralded the death of a white slaver and ridiculed the Cuban confusion in hailing a souteneur as a patriot. ${ }^{9}$ Perhaps, the Cuban "confusion" as to whether Yarini was a white slaver or a patriot was quite intentional—he could be both. As many habaneros saw it, Yarini had been "martyred" by French pimps who resisted the rising power of a Cuban chulo. Or perhaps the other popular interpretation was true: he was assassinated by the opposition in a complex internal political conspiracy to extinguish his rising political star. The funeral of Yarini was a milliarium in the annals of cubanidad, drawing citizens together in their grief and sorrow: Yarini’s death had cut short aspirations of a Cuban Camelot—-the Cuban dream of what might have been.

\section{Conservatives and Liberals}

Political turmoil, graft and patronage, legalized vice and prostitution, all characterized the capital city, where in 1910 the lottery was in full swing and cock-fights were scheduled each Sunday. ${ }^{10}$ As President, Gómez was amassing a personal fortune with every

${ }^{9}$ A few of the headlines made the contrast between Cuban hero and white slaver. See "Demonstrations over remains of bad man: Alberto Yarini, who assaulted American Minister, is finally put to death,” Tampa Tribune 24 November 1910; "Demi-monde of Havana in funeral cortege," Tampa Tribune 25 November 1910; "Yarini, white slaver dead: Mob at bier of notorious Havana character killed in a pistol fight," New York Times, 24 November 1910; "Laud Yarini as a patriot: Cuban popular idol for antiAmericanism, although a white slaver," New York Times 25 November 1910; and "Honor dead white slaver: Thousands of Cubans march in the funeral of Alberto Yarini," Washington Post, 25 November 1910.

${ }^{10}$ Wright, Cuba, 187. 
government project he authorized: purchases on navy vessels, dredging projects, loans, railway construction projects, lottery collectorships, bids for arms, and aqueducts, to name a few. ${ }^{11}$ As a result, his Liberal party was splintering over how to distribute the bounty. Political unrest, however, was not limited to intraparty squabbles. The Agrupación de Color sympathizers were agitating the Afro-Cuban citizenry across Cuba seeking economic and political redress and, for their part, in a bid to oust Gomez and his Liberal Party, the Conservatives had organized numerous political rallies that disrupted both Havana and the surrounding townships.

In San Isidro, however, at least on the surface, life remained ordered and honor welldefined, even if under a unique rubric. By the end of the second U.S. occupation in 1909, Yarini had already acquired a reputation as the quintessential public man, brave and honorable, who ably took on the American Goliath in defense of cubanidad, in spite of (or because of) his sideline, prostitution. Consuelo la Charmé, a prostitute who began to ply her trade at that time, remembered that Yarini "not only was a good man, but a friend, yes, sir, a good friend; the kind that when one was really in trouble [jodida] you could count on for help, without any conditions; he expected nothing in return, even though he was a politician, and a Conservative." She boasted that "he would not greet you because you were a somebody. No! He would speak with a Negro; or a Chinese; with anyone. He did not tolerate anyone who put on airs." ${ }^{\text {12 }}$ Yarini was highly respected among the inhabitants of San Isidro because of the aristocratic and political connections that he

\footnotetext{
${ }^{11}$ Bradley, Havana: Cinderella’s City, 399.

${ }^{12}$ Fernández-Robaina, Recuerdos secretos, 26.
} 
regularly used to help his friends and anyone else who sought him out. Although perhaps funded by the Conservatives looking for votes, Yarini offered financial assistance to anyone out of work or in need; he was, according to Consuelo, "the first to open his bag and the last to close it."13 Yarini’s high regard in Havana may have been his downfall because of the political danger his esteem among the lower classes posed to all other factions of the political class.

In spite of his admiration by the public, Yarini's professional life was not all he had envisioned. The aristocrat entrepreneur and aspiring politician felt the pressures of white European immigration the government actively promoted. Within sight on his daily walks in San Isidro, lay the Triscornia immigrant reception center in Havana Harbor, built by General Leonard Wood in 1900 to process the large numbers of European and North American immigrants arriving in Cuba. ${ }^{14}$ In the barrio, Yarini’s status and ordered life was being challenged by the influx of French émigrés.

\section{Apaches and Guayabitos}

Considered a sign of modernity and affinity with the continent, upper class Cubans were generally fascinated with French fashion and customs and newspapers advertised the latest issues of Chic Parisien for the ladies’ reading pleasure. ${ }^{15}$ In San Isidro, there was a

${ }^{13}$ The term "bag" was used, Consuelo noted, since during this period Cuba had no national currency and gold and silver coins from various countries including Spain, France, and the U.S. were in common circulation. Ibid, 50; and Wright, Cuba, 67.

${ }^{14}$ Gott, Cuba: A New History, 118.

15 “Periódicos y Modas,” Diario la Marina, 27 November 1910. 
different reason for wanting all things French: prostitution clients considered French women as the most sensuous and desirable, so having a French pupila (intern prostitute) could generate significant income for an entrepreneurial chulo. Generally, French pimps in Havana handled women recruited in France and on occasion they would travel back to France or to the United States and bring fresh women for the trade (especially from New Orleans), while the well-bribed Havana city officials looked the other way. ${ }^{16}$ The economic implications of the rise of the French prostitution trade in San Isidro were significant for Havana life and politics and threatened Yarini's control of the barrio and his standing as "King."

The problem between the Cuban pimps (guayabitos) and the French pimps (apaches) had deep and contentious roots and had resulted in several altercations, knifings and fights involving the two groups during the previous year. ${ }^{17}$ It was allegedly during a recruiting trip in 1910 by one of the barrio’s French pimps, Luis Lotot, one of his women, “Petite

${ }^{16}$ American entrepreneurs also actively engaged in the trade. In July 1910, the U.S. Army alerted Cuban immigration official about the anticipated arrival of one, Vivian Arlington with a house at 32 Animas in Havana, who held women against their will for the purposes of running brothels in both Havana and Panama. The authorities were alerted that Arlington would indebt the women for passage and room and board and hold them until the debts were paid as prescribed by law; F.H. Larned, Acting Commissioner of Immigration, Washington, D.C., to the Commissioner of Immigration, Havana, Cuba, 12 July 1910, ANC, Audiencia de La Habana, Legajo 836/18.

${ }^{17}$ Diario de la Marina, 22 November 1910. Diario de la Marina was Havana’s most conservative newspaper with close ties to Spain and the colonial order. The editor of La Marina saw himself as "the sole zealous support of Mother Church in the Americas.” Wright, Cuba, 142-43. Apache was a term used to describe a young, lowerclass, pimp-type Frenchman with connections to the underworld. It was also the name of a dance popular in France at the beginning of the twentieth century which reportedly reenacted a fight between a prostitute and her pimp. The dance included the man slapping the woman and throwing her to the ground. 
Bertha” Fontaine, left Lotot's "house" in San Isidro for that of Yarini. Lotot had been away for some time, reportedly in California looking for new women to augment his stable in Havana. Lotot was regarded as a player in San Isidro and was known for his ability to evade immigration regulations; "he was a specialist in legal transgressions."18 Bertha decided—or was convinced— to leave Lotot's “house” reportedly because Yarini was a better man and more respected by the police and others who mattered. In San Isidro, for example, popular songs called coplas circulated freely and touted Yarini's threat to the French apache (pimp): "Frenchmen without honor/leave Cuba right away/if you don't want Yarini/to rip out your life."19 ${ }^{19}$ addition, in the ordered demi-monde of prostitution, the worst infraction a pupila could commit was to switch houses, leave a pimp, or overstep her “place.”20 Bertha’s move and Yarini’s acceptance of her into his prostitution network had far-reaching consequences: the French pimps were outraged by the potential loss of property and standing and Cuban guayabitos' livelihood was being threatened by Petite Bertha’s move and Yarini's reluctance to abide by San Isidro’s unwritten honor code of property.

Perhaps sizing up Yarini’s political and social connections and his reputation for "bravery" proven on numerous occasions including against the Americans, when Lotot

${ }^{18}$ La Lucha, 22 November 1910.

${ }^{19}$ Cañizares, San Isidro, 1910, 133. It has been noted copla, rhyming rhythmic songs used to express collective feeling and imagination, are colloquial expressions of deep-seated communal feeling and are rarely attributed to any individual author.

${ }^{20}$ Using boarding school euphemisms, Section 8 of Article 20 of the 1899 regulations of prostitution, states that prostitutes living in a brothel, with a female madam or a male pimp, will be called pupilas. Comisión de Higiene Especial. Reglamento de la prostitución en la ciudad de La Habana (Havana: M. Pulido, 1899) 12. 
returned from California from his latest procurement trip, he thought better of provoking a full-blown confrontation and decided to let the incident slide. Reportedly he concluded that he had "come to Cuba to exploit women, not to die for them. It was his professional ethic.”21 Honor was on the line, however, and according to one report the other apaches pressured Lotot to make an example of Yarini for the good of the group; after all, "what would the apaches do if all their women, both French and Cuban, were to leave them?”22 Frequent squirmishes, erupted over the next few weeks. Just a few days before the confrontation between Lotot and Yarini, it was reported the apaches and guayabitos had scuffled on the streets of San Isidro and Lotot had been stabbed and the little finger of his left hand amputated in order to save his hand. On the morning of 21 November 1910, Lotot was interviewed by Havana police about a charge against Yarini for assault with a deadly weapon in a confrontation over property rights of San Isidro's women. ${ }^{23}$ That evening, a group of French nationals including Lotot met at a café on the corner of Habana and Desamparados Streets where they reportedly were overheard plotting Yarini's murder in order to vindicate the honor of the French apaches. At the time, it was also rumored that the Liberals had been behind the plot, perceiving Yarini as a threat and wanting to get him out of the way in the upcoming elections. ${ }^{24}$ The darling of the Conservatives, Yarini was widely supported in Havana by politicians, and especially by

${ }^{21}$ La Lucha, 22 November 1910.

${ }^{22}$ La Lucha, 22 November 1910.

${ }^{23}$ Diario La Marina, 24 November 1910.

${ }^{24}$ Diario de La Marina, 24 November 1910; and Fernández-Robaina, Recuerdos secretos, 34. 
all sectors in San Isidro including guayabitos, powerful ñañigos, and laborers who considered Yarini their hero.

\section{The Ambush}

In either case, a plan was hatched and what followed was a carefully executed ambush, although at first the authorities regarded it as a crime of passion. On the appointed night, 21 November 1910, shortly after seven o'clock in the evening, Yarini made the rounds of his houses in San Isidro. Lotot and four of his companions, including a couple of Italians, left the meeting at the café and after stopping by another establishment to down a few more drinks, three of them stationed themselves on the flat rooftops opposite \#60 on San Isidro Street. Petite Bertha generally operated from the house at \#60, but that evening, Yarini had insisted she stay at his home on Paula Street. Yarini had gone to see how things were going with Elena, another of his women and was just leaving the house when Lotot and his colleague, Jean Petijean accompanied by Lotot, arranged to “bump into" Yarini on the street as he left Elena's house. ${ }^{25}$ Lotot already had his 38 caliber pistol drawn when he faced off with Yarini. Quickly realizing it was an ambush, Yarini drew his own pistol and fired off several rounds against Lotot and Petijean. The French cadre stationed on the rooftops and with help from several Italians fired back and

25 The Diario de la Marina identified the five men on the rooftops as Jean Boggio, César Mornan, Ernesto Laviere, Cecilio Bazzout, and one known simply as Valetit. Several witnesses testified hearing footsteps on their rooftops on the night of 22 November. Diario de la Marina, morning edition, 24 November 1910. The time is published in Diario de la Marina, as part of the official report of the incident of 21 November, signed by the Francisco F. Piñero and Jesús Olive. Diario de la Marina, 25 November 1910. As with most accounts, names and details with the telling and retelling become less clear over time. Consuelo remembered the number of assailants on the rooftops as only two. Fernández-Robaina, Recuerdos secretos, 50. 
seriously wounded Yarini who apparently never saw them. José "Pepito” Bastarrechea, Yarini's constant companion and fellow Conservative who was in the house next door, heard the shots, ran outside, and fired at the pair of Frenchmen in the street. One round felled Lotot immediately, piercing his forehead. ${ }^{26}$ Bastarrechea, who was reportedly a very good shot, fired at the men on the rooftops, who quickly dispersed, and the Cuban took flight out of San Isidro, throwing his pearl-handled revolver in the gutter (Yarini owned an exact duplicate— both gifts from an admirer). ${ }^{27}$

Within minutes, the police descended on the barrio en masse. Twenty-two were quickly arrested in the round-up including eight French and two Cuban women and Bastarrechea. ${ }^{28}$ Seriously wounded, Yarini was taken directly to the Emergency hospital while Lotot was transported to the closest First Aid station. Lotot had been shot five times, with the fatal shot piercing his forehead. He was pronounced dead on arrival and identified by Jennie Fontaine (Petite Bertha’s sister and Lotot’s principal concubine) as a 28 year-old chauffeur. His body was sent to the morgue and prepared for burial the next day. ${ }^{29}$ At the time, Jennie accused Bastarrechea of killing Lotot.

${ }^{26}$ La Lucha, 22 November 1910.

${ }^{27}$ Testimony of Federico Morales Valcarcel to Dulcila Cañizares; Cañizares, San Isidro, 1910, 138, 158-61.

${ }^{28}$ Diario de la Marina, 22 November 1910; La Lucha 22 November 1910.

${ }^{29}$ Diario de la Marina, 22 November, 1910. 
At the hospital, while Yarini was being treated, Berta Fontaine, Cecília Martín, and Elena Morales, his “favorites,” paced in the waiting room. ${ }^{30}$ Yarini’s father and brother soon arrived and were told by the attending physicians that there was little hope of Yarini's survival. The shots from the rooftop assailants that hit Yarini were minor, but two of Lotot's bullets, shot at point blank range, pierced the groin area and organ damage was extensive. Emergency surgery only confirmed the diagnosis. Dying of his gunshot wounds, somehow Yarini learned that Bastarrechea was being accused of murdering Lotot. In what some describe as the last honorable deed of an honorable man, Yarini made a deathbed confession in which he took sole responsibility for Lotot's death. Written on hospital stationery, the pencil-scribbled confession was witnessed by Conservative Party leader, Fernando Freyre de Andrade, who was at Yarini’s bedside. ${ }^{31}$ The note read, "Concerning the shots that killed the Frenchman, I am solely responsible; I shot him in self defense.” No one expected less, "after all,” Consuelo noted, "that is how true men act."32 With identical pistols owned by the two friends, it could not be proved otherwise.

Havana's morning newspapers of 22 November carried the story of the shooting on its front pages. Yarini was pronounced dead that afternoon and news of Yarini's death spread like wildfire through Havana, “almost as if the President himself had died,” noted

${ }^{30}$ Diario de la Marina, 23 November 1910.

${ }^{31}$ La Lucha, 23 November 1910. A facsimile of the exculpatory note, entered into the police record, is reproduced in Cañizares, San Isidro, 1910, (unnumbered pages at end of the book)

${ }^{32}$ Fernández-Robaina, Recuerdos secretos, 39. 
one guayabito. ${ }^{33}$ According to his death certificate filed in the North Havana Civil Register, Yarini died at 2:30 p.m.

While being a chulo in Havana's barrios often involved violence and even death, the murder of Yarini had important repercussions for the city of Havana. La Lucha reported that all across Havana Yarini's death had prompted a call for revenge; police officers had to be stationed along the streets when Lotot's body (followed by 6 or 7 carriages) proceeded to the cemetery. Lotot's burial was held on the afternoon of the 22nd. As the French pimp’s small funeral cortege made its way back from the cemetery, a group of Cubans of "all races," ambushed the men in the carriages, attacking them with machetes and knives in an attempt to avenge Yarini's murder. ${ }^{34}$ The ambush after Lotot's funeral injured several Frenchmen, killing one, and resulted in several arrests; in response, the French assaulted the Cubans in the streets of San Isidro. ${ }^{35}$ The gory details were published in the papers the next day and implied the nañigos had been at work avenging their brother. Both Cuban and French pimps continued to exact vengeance, and their assaults, knifings, and shootings had the entire city on guard for several weeks. ${ }^{36}$ The retribution was spontaneous, but expected "a Cuban had been murdered by the apaches,

${ }^{33}$ Cañizares, San Isidro, 1910, 175.

${ }^{34}$ Diario de la Marina, 23 November 1910. Interestingly newspaper accounts erroneously reported Yarini died late on the evening of the 22nd - sometime after 11:00 p.m. Diario La Marina, 23 November 1910.

${ }^{35}$ La Lucha 23 November 1910.

${ }^{36}$ The police report of the details of the Cuban ambush of the French group at "El Bosque” was published in Diario de la Marina, 26 November 1910 as well as in several of the capital's newspapers. 
and complete justice was not to be expected from the authorities,” a prostitute later noted. After all, she continued, "the deceased was a conservative, the liberals were in power and had amiable relations with the apaches, who not only procured for them 'good women,' but also bags of money so they could continue their importation of women and profit from the prostitution trade in the area.”37 Almost immediately songs of warning were penned, like the one advising all Frenchmen to pick up their bedrolls and get out before Cubans broke ... their hearts:

San Isidro Street is draped in mourning

The women, filled with sorrow, weep in anguish

Because the lord of the pimps has died

Frenchmen, if you know what is good for you

Pick up your sleeping mats right away

Leave your lovers and take precautions

If you don't want us to break your . . .

$$
\text { hearts. }{ }^{38}
$$

${ }^{37}$ Fernández-Robaina, Recuerdos secretos, 50.

38 The coplas' words were, La calle de San Isidro de luto se halla vestida / Las hembras entristecidas sollozan con agonía / Porque a muerto el general de la chulería / Franceses, si ustedes saben que es bueno para ustedes/ Muden el catre enseguida / Abandonen a las queridas y anden con precaución /Si no quieren que le partamos el... corazón. Cañizares, San Isidro, 1910, 187-88. With a moralistic bent, La Marina 
The official response reflected Yarini's standing among the "gente decente." Perhaps in deference to his father's standing among the educated elite of the city, Yarini's death certificate and newspaper accounts listed his occupation at the time of his death as that of "student." ${ }^{39}$ The Conservative Party leaders requested permission to display the body for viewing at the Party headquarters, but Yarini's father refused their appeal. After a mandatory autopsy as part of the investigation, the body was kept in a refrigerated casket and taken to the family home on Galiano Street. As customary, announcements of Yarini's death were circulated throughout the city and published in all the daily papers. The family’s announcement, signed by all the men of the Yarini and Ponce de León families, ran in the major newspapers alongside that of the Conservative Party:

\section{R.I.P.}

\section{ALBERTO YARINI Y PONCE DE LEÓN HAS DIED}

Subscribers, Presidents, Delegates, and Secretaries of the National Conservative Party, beseech all affiliated with the Party and all the population in general attend the viewing, Calzada de Galiano, No. 22, tomorrow, Thursday, the 24th

published a different copla in the "Nota del Día," "El infeliz San Isidro / tiene un barrio que es un censo / pues por mucho que en el are / no sacara nada bueno." Diario La Marina, 23 November 1910.

${ }^{39}$ Death Certificate of Alberto Yarini Ponce de León ; Sección de Defunciones, Registro de Estado Civil de Norte Habana, Certificado de defunción, Defunción de Alberto Yarini, Tomo 13, Folio 291. 
of this month, at 9 a.m., and accompany the body to the Colón Cemetery, this kindness will be greatly appreciated.

The notice was signed by all the leaders of the Conservative Party who were among the most prominent men in the city. ${ }^{40}$ The list included war heroes such as Commander Miguel Coyula, who fought under General Mario Menocal in 1898; government officials such as General Fernando Freyre de Andrade, a veteran of the Independence wars, who had served as judge of the Supreme Court under Estrada Palma and then was appointed to the first Cabinet as Secretario de Gobernación in the same administration (the Emergency Hospital in Havana was later named for him); and Jose "Pepito” Bastarrechea. ${ }^{41}$

For Cubans, the velorio (viewing) was perhaps the only event that allowed few excuses for not attending. Diligence in expressing a pésame (expressions of condolences) was equated with honor for the dead and respect for the family’s standing. For example, writing in 1861, a visitor to Havana, Nicolás Tanco Armero, noted habaneros “in this are very attentive, sometimes too much so."42 For Cubans, velorios and funerals are indicative of social and community status and social responsibility. Several massive

${ }^{40}$ The names listed were, Federico G. Morales, Domingo J. Valladares, General Fernando Freyre de Andrade, Commandante Miguel Coyula, Commandante Armando André Antonio León, Capitán Emilio Sardiñas, Federico Caballero, Raúl Busquet, Pedro Quiñones, Ambrosio J. Hernández, José Bastarrechea, and Eduardo Infante. Diario la Marina, 23 November 1910.

${ }^{41}$ Willis Fletcher Johnson, The History of Cuba, Vol. 4 (New York: B.F. Buck \& company, 1920), 315.

42 "En esto son cumplidísimos, y algunas veces se pasan en serlo, pues aun no ha agonizado el paciente cuando ya vienen a acompañar la familia en su próximo dolor." Nicolás Tanco Armero, Viaje de Nueva Granada a China y de China a Francia (Paris: Imprenta Simón Racon, 1861), 50. 
expressions of grief held in Havana during the first years of the young Republic, such as the one for Máximo Gómez were indicative of popular support for its fallen heroes.

Answering the call, "guayabitos, ñáñigos, and people of all social classes” attended Yarini’s viewing. Dressed in their most somber clothes, trying not to attract undue attention, most of the prostitutes of the city also went to pay their last respects; a few were accompanied by their "husbands. ${ }^{43}$ Even some of the apaches' prostitutes went to the Yarini family home at \#22 Galiano. An unidentified woman of aristocratic bearing dressed in black organza with a large-brimmed hat and dark veil stoically stood watch over the body throughout the night. Few left the street outside the Yarini home creating an impromptu public vigil.

On 23 November, during the all-night velorio, so many people converged on 22 Galiano Street that crowd control became an issue. ${ }^{44}$ The men in the crowd formed an impromptu human barricade, creating a path for mourners who wished to express condolences to make their way to the home’s front door. Mourners formed an orderly line and entered the home in single file, walking past the body and paying their respects to the family who received visitors throughout the night in their living room. The preparations for the capilla ardiente (funeral arrangements) were under the care of Infanzón funeral home and the adjacent room, where the corpse was displayed, was filled to capacity with wreaths

${ }^{43}$ The prostitution regulations of 1899 restricted garish dress outside the zones; Comisión de Higiene Especial, Reglamento, Capítulo I, Artículo 10, Número 5.

${ }^{44}$ Noting police were needed for crowd control, the Tampa Tribune first reported the large numbers assembled at the Yarini home for the all-night vigil. Tampa Tribune, 24 November 1910. 
and flowers of every description. ${ }^{45}$ Indicating the variety of social classes represented in the crowd, some of the dedicatory ribbons accompanying the flowers were from known prostitutes, while others were from the politically well-connected:

To my unforgettable Alberto Yarini, from Mercedes Tamayo.

R.I.P. Alberto Yarini, with fond memories from Sara López.

To her unforgettable Alberto, with fond memories from la Johly. ${ }^{46}$

To Alberto, the National Conservative Party.

To our unforgettable President, the Conservative Committee of San Isidro.

Amid the messages and flowers, the deceased's family sat and stood by the door in a funereal receiving line. Four enormous silver candelabra provided an eerie light as a steady line of visitors passed by the coffin to see the hero of San Isidro one last time. ${ }^{47}$. Several women in the crowd gathered outside the Yarini home wept quietly throughout the night, but in the morning, when it came time to move the coffin from the house to the funeral carriage, most wept openly and loudly, the embodiment of Cubans' dramatic

${ }^{45}$ El Mundo, 19 June 1905. The Capilla ardiente, literally "burning chapel” is used to describe a sort of lying-in-state, generally on a raised dais, often used in the case of important citizens.

${ }^{46}$ Much has been conjectured about La Johly, the mysterious woman in the veil, she was reportedly the married daughter of one of Havana's premier jewelers, J. Borbolla and one of Yarini’s lovers who visited him in disguise in San Isidro. Cañizares, San Isidro, 1910, 167.

${ }^{47}$ Fernández-Robaina, Recuerdos secretos, 36-46. 
bereavement rites. ${ }^{48}$ The funeral cortege that left Galiano at 9 a.m. on Wednesday for the Cementerio Colón included thousands of habaneros, and stretched more than three city blocks with crowds lining the sidewalks and gathering at every cross street along the funeral route. ${ }^{49}$

In Western culture, such extensive funerals were generally the purview of royalty and privileged nobility. The European version of funeral spectacle, the royal funeral, offered times and physical spaces where subjects of varying stations could co-exist with little turmoil, if only for the few hours of the funerary liturgy. Processions were generally ordered according to rank and dominated by social expediencies. Following European tradition, in the colonies the death of King Maximilian of Mexico, for example, allowed all classes of society access during the commemorative pageants. The honored changed slightly as the Enlightenment championed the ideal of the "great man" as a "countermodel to king and nobility.” ${ }^{50}$ As linkages between religious and secular society were

${ }^{48}$ Ibid., 45. The countless stories associated with the graves at the Cementerio Colón, noted for their elaborate designs, are a tribute to Cubans' sense of drama in their tributes to the dead. More than 800,000 are interred in Colón in a system of burial crypts and ossuaries; there are more than 500 major mausoleums, chapels, and family vaults, many serving as semi-holy places for the community. Colón is one of Havana's major tourist attractions and site of pseudo-religious pilgrimages, especially to the tomb of Amelia Goire, "La Milagrosa" who died in 1901. In 2001, when the author visited Colón, the Yarini family gravesite was on a far back street, unassumingly simple, consisting of two plain sarcophagi, quite barren, and rather neglected. For a description of the layout and major monuments in Cementerio Colón, see Lohania Aruca, Narciso Menocal, and Edward Shaw, "The Cristobal Colón Cemetery in Havana," The Journal of Decorative and Propaganda Arts 22 (1996): 36-55.

49 The Associated Press report of 24 November anticipated crowd control problems during the funeral procession expected that day. Tampa Tribune, 24 November 1910.

${ }^{50}$ Avner-Ben, Amos, “The Sacred Center of Power: Paris and Republican State Funerals,” Journal of Interdisciplinary History 22, no.1 (Summer, 1991): 32. 
breaking apart in the republican era, the populace enjoyed the free spectacle afforded by a society funeral. In European countries the Christian ideal prescribed that, grief should be expressed with solemnity, restraint, and egalitarian simplicity," even at public funerals. ${ }^{51}$

With the Age of Revolution, the homage paid to titles and nobility began to be replaced by adulation for independence heroes. In the Americas, after independence, the place of honor was largely reserved for the hero who fought for the nascent state: the caudillos de independencia. The caudillo or hombre fuerte (strong man) served as the model the new nation was encouraged to emulate; enshrining their feats in the collective memory through public homage became a governmental imperative and a means of providing a guiding fiction of nation. For new nations, lacking a common history and looking for role models, these heroes represented patterns of unselfishness and beneficence, of courage and unmitigated service, as the population shifted from subjects to citizens. They were not considered great men because of lineage, but rather because of their accomplishments and contributions to the new society and thus their standing was predicated on a new order. The funeral of George Washington, for example, was accompanied by an elaborate funeral service and interment at Mt. Vernon, which Martha watched from an upstairs window. The service included cavalry, infantry, cannons, a riderless horse, solemn music and hundreds of mourners gathered at the General's country estate. Across the thirteen states, mock funerals and eulogies were organized to

${ }^{51}$ Ibid. 
honor Washington. ${ }^{52}$ It was noted that with such ceremonies, citizens were united forever with the countrymen they "loved”- even if it was a sort of "arranged marriage.,"53

For Cuba, the development of state funerals was not as linear, because the subject-citizen lines were blurred by the length of the colonial experience. For example, in preindependence Havana, when José Antonio Cortina, author and journalist died at age 31, his funeral in 1884 produced an outpouring of sentiment, as perhaps the most spectacular in nineteenth-century Cuba. ${ }^{54}$ The widespread mourning was catalogued in a compilation of funeral elegies and published in 1884, Corona fúnebre literaria en honor del ilustre cubano Don José Antonio Cortina. From one of Havana’s most elite families, Cortina was a young aspiring politician, man of letters, and editor of Revista Cubana; his death was used by the Partido Liberal in what Ana Torres and Adrián López call a

${ }^{52}$ Marcus Cunliffe, George Washington: Man and Monument (New York: Penguin, 1982); Jerry Hawn, “The Funeral of George Washington,” Mall Times, September 2007, http://www.nps.gov/mall/parknews/upload/MallTimes1.pdf, (accessed 9 January 2011). In contrast, Símon Bolivar’s embalmed body was laid in the Customs House, and while many crowded in the building to see the body. Although church bells tolled to announce the requiem mass, the funeral procession and interment at the Cathedral of Santa Marta was subdued; Bolivar enjoyed more adulation after his initial interment. His body was subsequently reinterred in Caracas Cathedral in 1842, and in the National Pantheon in 1876. John Lynch, Símon Bolivar: A Life (New Haven, CT: Yale University Press, 2007), 278-279. In a sentimental and dramatic ceremony in 2010, Venezuelan president Hugo Chavez had Bolivar's remains exhumed, and while the Venezuelan national anthem played, broadcast images of the hero's skeleton national television. Chavez ordered a DNA test of the bones to determine if Bolivar had been murdered. Chavez claims solidarity with Bolivar as "the father of the revolution." Gustavo Valdes, "Venezuelan TV Shows Exhumed Skeleton of Former Military Leader," CNN.com, 17 July 2010 http://articles.cnn.com/2010-07-17/world., (accessed 9 January 2011).

${ }^{53}$ Ana Meylin de la O Torres and Adrián López, "José Antonio Cortina: muerte civil, prensa y patriodrama,” Debates Americanos 4 (November-December, 1997), 4.

${ }^{54}$ Ibid., 8 
"patriodrama" with the press mediating the funeral rites as a sort of "priest." According to the press, the funeral allowed "all classes" to be represented and the procession took on the air of a civic demonstration. In addition, the authors commented that in the hyperbole of numbers reported in attendance and the extravagance of homage rhetoric, Cortina "ceased to be a person, and became a symbol ... and the solemnity of his funeral acquired ... all the characteristics of a historical journey." ${ }^{55}$ Indicating the admiration of the people, the press reported that the bier was carried along from shoulder to shoulder, including "those of a few black women whom no one could identify." In addition, the procession was accompanied by African drums, and by an "irreverent” tune from the Raimundo Valenzuela band. ${ }^{56}$

The components of the procession for Cortina's funeral were common to those of other "great men,” whether in Europe or America. Each usually included army units, an elaborate hearse and the family, civic and religious leaders, and delegations from popular organizations and societies with which the deceased was associated. In his analysis of republican state funerals, Abner Ben-Amos argues that state funerals "provided a complex narrative for spectators ... [telling a story] by the order of the marchers and the relative closeness of each segment to the hearse.” He noted that the procession's unfolding story was told by the proximity of the mourners to the corpse as indicative of
55 Ibid.
56 Ibid. 
the state's formal structure. ${ }^{57}$ The pomp and circumstance of republican state funerals found a new dimension in the Americas as new cultures and traditions were incorporated.

In Havana’s ever-changing social landscape, funeral practices were worthy of note. For Cubans attending a funeral in a motorized vehicle was frowned upon, as a somber walk to the cemetery was the accepted way to pay respects—although the carriages of the well to do and those for hire lined up outside the cemetery for the ride home. ${ }^{58}$ In keeping with the patriarchal script, women were not allowed to participate in the procession and generally had to be content to observe from a window or balcony. Publishing funeral announcements was an almost obligatory custom in order to attract the largest possible expression of condolence and ensure a good turnout: through newspaper advertisements for the elite and by word of mouth for the lower classes.

There was also prescribed funeral attire for Havana funerals: the family dressed in austere mourning clothes, while acompañantes wore well-pressed white pants and patent leather shoes. It was noted that, "if you did not catch a glimpse of the first coach carrying the remains accompanied by zacatecas (professional funeral attendants sometimes driving the hearse) you might think that instead of a funeral, the procession was a society promenade.” This was in sharp contrast to customs in cities such as London where somber and solemn tribute was customary and "mass discipline and silence ...

${ }^{57}$ Ben-Amos, "The Sacred Center of Power," 34.

${ }^{58}$ Miguel A. Rivas Agüero, "Velorios y entierros en el viejo Camagüey,” in María Antonia Crespí, ed. El Camagüeyano (October 1987). Online reprint in Victor Romero Soñora, “Recuerdos de Camagüey.” 23 October 2009. http://lagacetadepuertoprincipe.com/2009/10/velorios-y-entierros-en-el-viejo.html, (accessed, 12 November 2009). 
astonished [foreign] observers." ${ }^{59}$ As one spectator noted at the time, public spectacle associated with funerals was perhaps “. . . more suited to the Latin temperament.”,

Religious observances aside, popular support for state funerals was undeniable. From 1884 until 1951, the Havana press reported approximately 37 public funerals drawing significant public attention, with 16 in Havana commemorating military heroes. Several of Havana's popular expressions of grief were the result of disasters and group funerals, in part accounting for the widespread attendance: the funeral of the Havana firefighters in 1890, ceremonies from the casualties from the explosion of the U.S.S. Maine in 1898, and those from the sinking of the luxury cruise ship, Valbanera, in 1919. If, as has been argued, funeral rituals provide a symbolic function of great importance for the individual and for groups, then the grand interment of two military heroes and the commemoration of the deaths of seven others in the period from 1906 through 1910 may speak to the need for politicians to establish the nation's unifying paradigm. ${ }^{61}$ Cuba's leaders, in Havana in particular, continued to try to find ways to evoke and coalesce a model of nationhood. ${ }^{62}$

${ }^{59}$ The term zacateca is used almost exclusively in Cuba and describes a funeral attendant, usually associated with pomp and regalia of colonial funerals; Robert Justin Goldstein, "Political Funerals,” Society, (March-April, 1984), 18.

${ }^{60}$ Gavin Weightman, "Was it British? Social Analysis of Public Grieving Rituals in Great Britain,” History Today, November 1997, 6-7.

${ }^{61}$ Roger Grainger, The Social Symbolism of Grief and Mourning (London: Jessica Kingsley Publishers, 1998), 105.

${ }^{62}$ The figures and interments cited is gleaned from the analysis of the author of public funerals reported in the Havana press between 1898 and 1950. 
As already noted, in 1905, the public funeral of Máximo Gómez gripped national and international attention as a nation honored its adopted general. The body lay in state at the presidential palace flanked by an alternating honor guard representing different sectors A heterogeneous multitude attended the corpse at every stage and the national grief resonated throughout the provinces. ${ }^{63}$ El Mundo reported that "Havana has never witnessed such an expression of corporate grief” [far beyond the official expediencies, it was] the people ... [who] enveloped the gun carriage for its journey from the presidential palace to the cemetery.” The editor complained that officials intervened to prevent the people from hoisting the body aloft and carrying it on their shoulders all the way. The police intervened as violence erupted in front of the Hotel Inglaterra when several men lunged into the procession to attempt to carry Gomez’ coffin on their shoulders; nearby, as flowers rained down onto the coffin, several ladies fainted and fell out of the balconies onto the street. ${ }^{64}$ The official escort to the cemetery was so impressive that even the U.S. press found it formidable.

Such outpouring of patriotism may have prompted the flurry of commemorative observances that followed the spectacular interment of Gómez. Exhumations and reburials for other war heroes such as Antonio Maceo and Calixto García in 1906 and for Vicente García and Néstor Aranguren the following year were arranged. ${ }^{65}$ The latter

${ }^{63}$ El Mundo 21 June 1905.

${ }^{64}$ El Mundo, 19 May 1907.

${ }^{65}$ As reported by the press, the most popular funerals exhibited commonalities as the mourners were myriad and of all classes, flowers rained down from balcony windows, and men vied for an opportunity to carry the coffin on their shoulders -- which the police always had to stop. 
was not as well attended as the press had anticipated and with the death and interment of General Bartolomé Maso, the zeal for honoring fallen independence heroes peaked by 1907. In 1909 there were no public funerals held, as the Republic once again made the transition from U.S. occupation to independence. In October 1910, the last official "public" funeral of the year was staged by officials when the transfer of General Francisco Aguilera, first Vice President of the Republic at Arms, from New York City to his final resting place in Bayamo was arranged. Less than a month later, there would be a similar funeral, although this one was for a "student” and would leave from a private home rather than from a state building. ${ }^{66}$

As already described, the procession that accompanied Yarini's body to the cemetery was varied and impressive, growing longer as it made its way down Havana's most important boulevards. When the body of the young politician passed in front of the headquarters of the Conservative Party, flowers rained down on the coffin from every window. Police monitored, reportedly without incident, scuffles over who could carry Yarini’s coffin on their shoulders. Public grief and sorrow transfixed Havana in a conflicted mix of disbelief and mourning for their dead hero.

${ }^{66}$ Tampa Tribune, November 25, 1910. Irene Wright described the funeral of Gómez in much the same terms as news accounts described Yarini's cortege. Wright, Cuba, 78-79. For varying descriptions of Yarini's funeral procession, see Diario de la Marina (Havana), 25 November 1910; the New York Times, 25 November 1910; and the Washington Post, 25 November 1910. The Tampa Tribune carried the story of the viewing on 24 November 1910 and the next day offered coverage of the funeral. 
Many more mourners awaited the cortege at the cemetery where the military commander, Miguel Coyula, gave the eulogy and a Catholic service was held at the Colón chapel. ${ }^{67}$ The body was laid to rest in a simple sarcophagus owned by the Yarini family. ${ }^{68}$ The ñánigos also had a farewell ceremony, el enyoró, for Yarini in the field beyond the cemetery. ${ }^{69}$ The Abakúa ceremony, also called la despedida (the farewell), was a type of ovation to the dead to welcome the deceased into the next world. It confirmed for many Yarini's membership in the secret society because it could not be administered unless the deceased was an initiate. The liturgy of the Abakúa ceremony was a closely held secret but the drumming and the singing of the ñánigos could be heard throughout the cemetery and its surroundings. ${ }^{70}$ The events of the week of 21 November 2010 captured the public imagination and the sensational and satirical La Caricatura, was quick to chronicle the events in a front page picture spread featuring a sketch of the debonair Yarini, with his hat tilted back on his head, the dead Frenchmen on their morgue slabs, a reenactment of

${ }^{67}$ Fernández-Robaina, Recuerdos secretos,, 36. See footnote \#1 for a listing of newspaper coverage of the Yarini viewing and funeral.

${ }^{68}$ The cemetery plot was purchased in 1898 by José Leopoldo Yarini; NE, 24cc, Bv 1 Archivo Cementerio Colón, Registro de Asentimientos, Asentimiento \#1710. Cirilo Yarini was interred in the adjacent sarcophagus on 7 February 1915, Archivo Cementerio Colón, Registro de Asentimientos, Asentimiento \#1263.

${ }^{69}$ Fernández-Robaina, Recuerdos secretos, 40.

${ }^{70}$ Conversation with author, 24 January 2001, “El Negro” Vargas, at the National Archives in Cuba. 
the ambush on San Isidro streets and photographs of the Guínes meeting and the crowds that accompanied Yarini's coffin. ${ }^{71}$

${ }^{71}$ La Caricatura, “Los sangrientos sucesos de San Isidro,” 25 November 1910. Colón 
10 , 
By 24 November Diario de la Marina reported that the chief of police was proceeding to "clean-up” San Isidro with an iron hand, moving against all those violating existing immigration and prostitution laws; the lottery and political corruption were not subjects of the clean-up. His draconian measures were directed against the city's pimps and prostitutes. Even some members of the police force were reprimanded; police captain Ledón of the 10th precinct, for example, was dismissed for negligence in preventing the incidents associated with the ambush during Lotot's funeral. ${ }^{72}$ The brunt of the measures, however, was imposed against the prostitutes who were indiscriminately rounded up and sent to the vivac. Prostitution establishments and businesses in San Isidro were repeatedly “inspected," heavy fines imposed, and many ordered to close down. ${ }^{73}$ Several citizens were falsely accused and arrested for various charges allegedly related to the prostitution trade and many women resorted to fletear (turning tricks in the streets) in order to subsist. ${ }^{74}$

From all provinces of the country newspaper editors reacted, firing off editorials demanding more stringent government action. ${ }^{75}$ The initial response of Diario de la Marina was to blame the U.S. for what happened. "The Americans outlawed cock fights,

${ }^{72}$ Diario de la Marina, 24 November 1910.

${ }^{73}$ Diario de la Marina, 30 November 1910.

${ }^{74}$ Diario de la Marina, 28 and 29 November 1910.

${ }^{75}$ Diario de la Marina mentions other newspaper coverage including Havana's El Mundo and Camagüey's El Comercio, and repeatedly refers to the "immoral press," that the editor claimed sensationalized the events to increase circulation: "almost all Havana newspapers turn the accounts of the day's repulsive crimes into epic tales." Diario de la Marina, 27 November 1910. 
bullfights, and the lottery,” complained Joaquín N. Urumburú, editor of La Marina; "why then did they leave public prostitution? In the United States it does not exist, it is not permitted, and neither is it permitted in other civilized countries. ${ }^{, 76}$ In fact, during the initial occupation, the U.S. did not outlaw prostitution, but tried to enact and enforce prostitution regulations in Havana both in 1899 and again in 1902. The provisional government mandated the organization of the Department of Hygiene as an independently supported authority charged in part with monitoring prostitution and outlawed all unregistered prostitution.

Interestingly, while carrying heavy coverage of the arrests and "clean-up" campaigns associated with the murders, and publishing extensive editorials against legalized prostitution and in support of the police, La Marina did not carry any description of the funeral procession, only noting that police were on hand the day of Yarini's funeral in case of disturbances. Its coverage of the events was largely in the form of extensive editorials and official reports. For example, a two-part editorial appeared under the rubric, "Por el bien de Cuba," in the morning editions of 25 and 26 November criticizing the administration and calling for abolition of the trade. In the afternoon edition of 25 November, in a front-page editorial the newspaper's editor lambasted the city's immoral image as regressive and a cause of shame for Cuba before the international community: "Where such things happen,” Urumburú lamented, "how can anyone expect the regeneration and prosperity of collective honor and national strength?”77

\footnotetext{
${ }^{76}$ Diario de la Marina, 22 November 1910.

${ }^{77}$ Diario de la Marina, 25 November 1910.
} 
The afternoon editions on those two days also featured Baturillos, or random thoughts, on the "bloody occurrence" in San Isidro. The murder of Yarini and the two Frenchmen had "revealed, through the power of scandal, a terrible evil, a hub of moral corruption, against which [the editors] have been incessantly clamoring, although society, in whose interest we cry out, has not paid attention.” The article continued, "three men are dead . . others are injured; some are in prison; a respectable home is draped in mourning; the gray hairs of a learned old man and the decorum of an honest family stand in contrast against the irrational acts of a [dead] son ... new crimes are committed daily; and all eyes, frightened and curious, turn to that diseased zone where chulos and horizontales [prostitutes] disgrace our country, while the authorities complacently stand by.",78

The moralistic editor of Diario de la Marina also noted the prevalence of "an interminable series of pornographic stories and illustrations, postcards and epigrams, and impudent tales printed in newspapers read by women.” These publications, according to Urumburú, had made vice acceptable for Cuban society. ${ }^{79}$ While denouncing public indifference to vice, the paper also published portions of letters received from readers who voiced similar opinions; but sadly, the editor noted, these numbered only "six or eight.” One letter in particular, from a "Galician,” generated a long and pointed response. The writer contended that while regulation of prostitution was necessary in modern society, he doubted that prohibition was effective, and thought that it was actually immoral. Urumburú's response sharply criticized both society’s acceptance of “immoral
${ }^{78}$ Ibid.
${ }^{79}$ Ibid. 
vices" and the corrupt government officials who "told prurient anecdotes" in some of the most respectable living rooms of the capital and winked at the increase in prostitution and vice. $^{80}$

Two days after the shooting, Havana’s mayor ordered several brothels in the city closed. However, an editorial by José Viera published in Diario de la Marina, doubted the mayor's efficacy: "Instead of paying for their lawlessness with a jail sentence," noted Viera, "[the accused] put on airs of great gentlemen. Today, any miserable person who lives from prostitution ... looks down upon decent people with disdain and speaks with pride of his many spheres of influence ... The world belongs to murderers and prostitutes.” The piece ended with “We'll see, we'll see."

\section{Short-term repercussions}

The weeks after the funeral were devastating for the Yarini family. Cirilo, already in ill health, moved his family away from central Havana to the suburbs in Marianao. ${ }^{82}$ Uncle José de Jesús, permanently stopped all advertisements for his dental practice in Bohemia in December (which had run weekly in the magazine for several years). ${ }^{83}$ Sister Emilia (“Cuca") who was reportedly engaged to the harbor master, never married and lived out

${ }^{80}$ Diario de la Marina, 2 December 1910. title?

${ }^{81}$ Diario de la Marina, 23 November, 1910. title?

${ }^{82}$ Cirilo Yarini died in February 1915 of arteriosclerosis, Archivo Cementerio Colón, Registro de Asentimientos, Cirilo Zarini (sic), Asentimiento \#1263.

83 “Directorio Profesional,” Dr. José de Jesús Yarini, cirujano dentista, is not listed after the 12 November1910 edition of Bohemia. 
her life in guest houses in Havana, working at the university as a clerk and later, living on a state pension. ${ }^{84}$

The trials of the men who had ambushed and killed the Frenchman Finet proceeded quickly and the Cubans -all working class unknowns - were convicted and sentenced to several years in prison. Arturo Nespereira was proud of his sentence, "I did what I had to do,” he recalled, "what Yarini would have done in my place.”, Leverie disappeared amid rumors that the Conservatives had paid them off so they could not testify at the trial of Bastarrechea. The proceedings surrounding the murders of Lotot and Yarini dragged on into the following year with investigations, depositions, and hearings but little official consensus as to what charges could be prosecuted. Eventually, the charges against Bastarrechea, a Conservative and friend of Yarini, were dropped in May 1911. The closing record of the proceedings was the petition by Cirilo Yarini to the Audiencia to retrieve his son’s possessions held as evidence. They were returned. ${ }^{86}$

For all the governmental and media hyperbole and publicity following the death of Yarini, little permanent change actually ensued after 1910. Prostitution issues in Cuba took a back seat to the continued unrest of nation building for several decades after Yarini’s death. The limited response of Cuba's national government was ambivalent.

${ }^{84}$ AUH, Emilia María Mauricia Yarini y Ponce de León , Expediente administrativo, \#8427. Emilia retired on 30 June 1959 because she was sick. See also, Cañizares, San Isidro, 1910, 41.

${ }^{85}$ Cañizares, San Isidro, 1910, 213.

${ }^{86}$ ANC, Audiencia de la Habana, Legajo 643/3, Folio 247-248; and Cañizares, San Isidro, 1910, 27. 
Decree \#1158 closed San Isidro as a zona de tolerancia on 28 December 1911, and moved its operations to the barrio Luyanó. ${ }^{87}$ Under pressure, the move to Luyanó was nullified some ten months later with Decree \#883 dated 2 October $1912 .^{88}$ The Conservatives who had made some gains in the midterm elections continued to prepare for the national elections they would sweep in 1912 after Gómez announced he would not seek reelection. ${ }^{89}$ They managed to elect Conservative candidate Mario Menocal as the third President of the Republic, while fellow Conservative Freyre Andrade was elected Mayor of Havana. No doubt the memory of Yarini aided the Conservatives in their achievements.

A year after the elections, on 23 October 1913, the legislature suspended the regulations in force since 1899 and eliminated all specified zones for prostitution, thus relaxing all controls. Citing that the social and public health benefits envisioned by the drafters of the regulations had not materialized, the decree sponsored by the Department of Health and Welfare (Secretaría de Sanidad y Beneficiencia) instead contended that the opposite had occurred. State regulation had merely fostered pimping, criminalized women, and discredited the public administration. The decree further detailed that the obligatory

${ }^{87}$ The barrio Luyanó was bounded by the following streets set aside specifically for prostitution: Pérez, Arango, Juan Alonso, and Rosa Enríquez. In addition the decree moved the regulatory and enforcement powers from the Comisión de Higiene Especial to the Secretaría de Gobernación y Sanidad. The decree was signed by President Gómez and Gerardo Machado, then Minister of the Secretaría de Gobernación. Secretaría de Gobernación, Decreto No. 1158, Gaceta Oficial de la República de Cuba, 27 December 1911, 6653.

${ }^{88}$ The Secretary for the Ministerio de Gobernación was by then Federico Laredo Bru. Decreto No. 883, Gaceta Oficial de la República de Cuba, 4 October 1912, 4014.

${ }^{89}$ Diario la Marina, 28 January 1911. 
medical exam and hospitalization had proved ineffective in controlling venereal disease and instead offered the public a false sense of security. After a discussion of probable world opinion of a country that allowed prostitution to continue and the anti-republican nature of the current system of regulated prostitution in Cuba, the decree nevertheless stipulated the abolition of existing regulatory measures. ${ }^{90}$

Influenced by international pressure, the Cuban government at the same time subscribed to the international accords against the traffic in women published previously in 1904 and 1910. From 1911 until 1915 more than twenty new immigration decrees were enacted that restricted women traveling alone internationally, set the minimum age for women immigrants, required fingerprinting, and generally tightened controls for all immigrants. ${ }^{91}$ In particular, National Decree \#384 ensured Cuba’s support of the Convention by prohibiting and punishing the introduction of any women into Cuba for the purpose of prostitution. The flurry of activity by the Cuban government to mitigate the perception if not the practice of prostitution may have been calculated to enhance the nation's standing among the nations of the modern world, but avenging the murder of Yarini may have also

${ }^{90}$ Signed by President Menocal in October 1913, Decree \#964, voided existing regulations except for minors, made the treatment of syphilis the responsibility of local, not national authorities; eliminated the restriction of the trade to zonas; gave police greater power to arrest anyone engaged in "public" prostitution; allowed two months for the "public" image of brothels to be altered; moved the treasury of the Servicios de Higiene to the jurisdiction of the Secretaría de Sanidad y Beneficiencia; turned over all records of the Servicio to the Negociado de Higiene Especial de la Dirección de Sanidad; and entrusted the enforcement of the new decree to the Secretaries of Sanidad $y$ Beneficiencia, Gobernación y Justicia. The decree was signed by President Menocal and the Secretary for Sanidad y Beneficiencia, Dr. Enrique Núñez. Decreto No. 964, Gaceta Oficial de la República de Cuba, 23 October 1913, 5453-54.

${ }^{91}$ In 1925 Cuba ratified the resolutions adopted by the International Convention for the Suppression of the Traffic in Women and Children, dated 30 September 1921. 
been a motivating factor for the Menocal presidency whose main focus of repression was on the "foreign" aspects of the trade.

\section{Conclusion}

On 23 June 2001, Cuban dictator Fidel Castro made headlines on both sides of the Atlantic when he fainted during a speech in front of 60,000 spectators. Some six hours later, after returning to the podium to complete the speech, Castro's opening remark was to joke, "People might think that I faked my death to see what kind of funeral I would get." 92

Ironically, as in many cultures, for Cubans the amount and level of grief expressed at a funeral is the quintessential validation of life. ${ }^{93}$ Attendance at the velorio and interment often underscores how well-respected and influential the deceased was in life. Velorios and funerals thus are indicative of social and community values and the individual's status and social responsibility within the community. Several massive expressions of grief were staged in Havana during the first decade of the Republic that were indicative of popular support for its fallen heroes but also part of the political machinations of elites to prescribe the heroes that would define the nation.

92 "Cualquiera diría que me estaba haciendo el muerto para ver qué entierro me hacían." Quoted in Mauricio Vicent, "Castro sufre una lipotimia durante un mitin televisado en directo," El País, 24 June 2001; and Nelson del Castillo, "Castro 'lamenta' que enemigos no celebraran con ron y whisky,” El Siglo, 25 June 2001.

${ }^{93}$ For a discussion of the importance of death and funeral rituals for citizens in Early Modern Spain see, Carlos M.N. Eire, From Madrid to Purgatory: The Art and Craft of Dying in Sixteenth-Century Spain (Cambridge: Cambridge University Press, 2002). 
Ascertaining the particularities of cubanidad remained a contentious process, nevertheless, as Cubans sought to craft models of a cubanidad of their own making. The post-independence ambivalence of a nation largely influenced and controlled by foreigners—politically, economically, socially, and even in its underworld -offered the Cuban people European and North American models for nationhood. Traditional histories of Cuba enshrine the caudillos of independence and marvel at the outpouring of national pride at their state funerals, yet there emerged few Cuban versions of a "founding father" to coalesce cubanidad. Martí was dead; Palma out of favor; and race issues marred the standing of independence war heroes. For Cubans, there remained little doubt who should represent them: Yarini was the virtuous hero and the true Cuban. 


\section{CHAPTER VII}

“EL CHULO QUE SOÑO SER PRESIDENTE” ": THE BIRTH OF A CUBAN MYTH.

Al fundir el corazón, en el alma popular,

lo que se pierde de nombre, se gana de eternidad.

From “Cualquiera Canta un Cantar” by Manuel Machado Ruiz, 1919²

In the months before April 1910, Havana was tantalized by stories of the appearance of Halley’s Comet as scientists with new technology predicted the earth would be engulfed in the comet's tail. ${ }^{3}$ The apocalyptic possibilities seemed endless as stories of the comet as a harbinger of racial catastrophe for the white population in Cuba swirled throughout the city. ${ }^{4}$ In the capital, Liberals and Conservatives were locked in ideological -and physical—combat over political supremacy in acrimoniously contested elections; the Agrupación de Color was loudly protesting white Cuban hegemony; apaches and

${ }^{1}$ Bohemia, “El Chulo que soño ser presidente,” (December 2001): 54.

${ }^{2}$ Manuel Machado Ruiz (1874-1947) was a Spanish poet and lyricist. The entire 4-stanza copla reads: Hasta que el pueblo las canta/las coplas, coplas no son/y cuando las canta el pueblo/ya nadie sabe el autor. Tal es la gloria, Guillén/de los que escriben cantares/oír decir a la gente /que no los ha escrito nadie. Procura tú que tus coplas /vayan al pueblo a parar/aunque dejen de ser tuyas /para ser de los demás. Que, al fundir el corazón/en el alma popular/lo que se pierde de nombre /se gana de eternidad. http://artespoeticas.librodenotas.com/artes/1195/cualquiera-canta-un-cantar-1919, accessed 10 October 2010.

${ }^{3}$ Halley’s Comet was visible over Cuba on 19 April 1910.

${ }^{4}$ Gott, Cuba: A New History, 122-23. 
guayabitos, armed with guns and knives fought openly in the streets of Havana, no longer restrained by fear of prostitution Reglamentos or by non-enforced immigration laws. ${ }^{5}$ By the end of the year, to this chaos and ambivalence was added the murder of one of Havana’s rising stars.

\section{The Martyr of San Isidro}

The death of Alberto Yarini y Ponce de León and the display of grief at his funeral offered a public acknowledgement of his "martyrdom" in defense of cubanidad. "When they killed [Yarini]," mourned Alberto Cardenas, "it was for us as if they had murdered the hero of our lives.” ${ }^{\prime 6}$ Through his connections, influence and comportment, which for many habaneros transcended class, race and gender, Yarini had been elevated to Cuban hero status, but how would the hero be honored in the ambivalence of Havana politics and society? Shortly after Yarini's death and impressive funeral, a group of habaneros (white and Afro-Cubans) formed the thirteen-member "Yarini Band" to perform tunes in honor of the fallen hero. Little else was done to officially remember Yarini or to enshrine him among the official "heroes" of the republic; his memory, however, lived on in the collective memory of Cuba, a reminder of what might have been.

\footnotetext{
${ }^{5}$ At about the same time as the expectation of Halley's Comet, the story of the "Mallorquina's" retribution on her philandering husband, which involved very sharp scissors, displaced the fear with laughter. The copla that became popular was "no te apures Enriqueta/el mundo ya no termina/porque ayer la mallorquina/le corto el rabo al cometa.” from “El Cometa de Halley,” http://adpuello.com/anecdotario.htm, accessed 4 June 2001. 99.

6 “Testimonio de Alberto Cardenas, 1970,” in Cañizares, San Isidro, 1910, 198-
} 
Memory, however, is at times fanciful. The human mind often reconstructs memory under the present pressures of society not the facts of the event. "The 'law of remembrance,"” Pierre Nora argues, "has great coercive force: for the individual, the discovery of roots, of 'belonging' to some group, becomes the source of identity." that sense, memory is a phenomenon Cubans have used to construct a sense of nationhood, of cubanidad, through a nostalgic reflection of the past in the person of Yarini. Countless have secretly (and recently more openly) identified with the man who could rule the barrio and lead the nation, providing consensus in the midst of political, racial, and class differences. Throughout the century since Yarini's death, he has been called up during critical inflection points in Cuban history. The countless telling and retelling of Yarini's story have embellished and appropriated the facts making them almost inconsequential, in the process, helping to create an imagined past for an imagined community.

\section{Long-term implications}

With little harmony Cuban politics continued its labyrinthine development. After the Menocal administration (1912-1920) which was marked by election fraud and violence including a failed insurrection not dissimilar to that of the second term of the Palma presidency, Cuba faced a dire economic future with the collapse of sugar prices and crippling U.S. tariffs on sugar. In response, a coalition of ex-Liberals and Conservatives joined forces and backed Alfredo Zayas for President in 1911. In 1924, Zayas, who was

\footnotetext{
${ }^{7}$ Pierre Nora, Realms of Memory: Rethinking the French Past (New York: Columbia University Press, 1960), 11.
} 
supposed to back a new bid for the presidency by Menocal, instead backed the Liberal Party candidate Geraldo Machado, a member of the Gomez cabinet and vice-president of the U.S. owned Cuban Electric Company. Elected on a platform of providing roads, water and schools for Cubans, Machado instead quickly gained control of the military and instituted violent repression against his opponents. He ruled Cuba with an iron hand until his forced resignation in 1933. Subsequent leadership in Cuba was short-lived and equally tumultuous. A glimmer of hope appeared under the presidency of Grau San Martin, physiology professor at the University of Havana, when as President he instituted reforms, called for the end of the Platt amendment, abrogated the 1901 constitution and called for a constitutional convention. That respite was shortlived. In 1940, Fulgencio Batista, an army officer turned politician, became the first president under the new constitution and later assumed a new role as dictator in $1952 .^{8}$

Between 1910 and 1940 a generation had come and gone and it seemed the memory of Yarini was forgotten. In the midst of constant and violent political turmoil, during the 1940s, with a new Constitution that guaranteed civil liberties and equal rights for women, Cuba renewed its emphasis on moral reform campaigns. In 1949, Bohemia, one of Havana's most enduring and popular magazines, ran a story which was little more than a recounting of the events of Yarini's life and death. It served as a warning of what might

\footnotetext{
${ }^{8}$ For an analysis of the events leading up to the Machado crisis, see Luis E. Aguilar, Cuba: 1933: Prologue to Revolution (Ithaca, NY: Cornell University Press, 1972.) For a discussion of the role of the military in twentieth century Cuba, see Louis A. Perez, Army Politics in Cuba, 1898-1958 (Pittsburgh: University of Pittsburgh Press, 1976). On the role of students in political upheavals in Cuba from 1930 - 1960, see Jaime Suchlicki, University Students and Revolution in Cuba (Coral Gables, FL: University of Miami Press, 1969).
} 
happen if society continued to embrace current morals (or lack thereof). Accompanied by a series of photographs and reproductions of the events of Yarini's death in 1910, the author was quick to point out that "in Cuba, to say Yarini ... was equated with having many women,” not with patriotic inferences. Interestingly, the story was punctuated by the retelling of the brawl at the Cosmopolita between the U.S. Charges de Affaires, G. Cornell Tarler, and Yarini. This time, however, it was reported Yarini fought against the Americans in defense of Jesús Rabí Sablón, independence war hero and Afro-Cuban leader, reinvigorating the racial dimension of the case at a time of renewed racial tension on the island. Rabí who was praised in American military reports for his bravery during the Independence wars, was never mentioned in court or newspaper reports or subpoenaed in the original Yarini depositions and trial in 1908. Rabí had stayed out of the limelight during the racial controversy that led up to the 1912 massacre of PIC members and was regarded by many as a model of racial "propriety."9

\footnotetext{
${ }^{9}$ Major General Jesús Rabí (1845-1915) - commanded 6600 troops in the second military division. Rabí was a symbol of the warring, conquering masculinity embraced by both the Cubans and Americans. After independence, however, he disappeared from leadership positions and was not active in political causes. He was a "safe" Afro-Cuban representative for the U.S. and Cuban politicians. A "hero" of the struggles for Cuban Independence, he joined the insurrection three days after Yara in October 1868. He fought alongside Máximo Gómez, and soon achieved the rank of Captain, later joining Calixto García in 1874 at San Antonio de Baja. Rabi participated in several major battles of the war and was made a lieutenant Colonel in 1890. In 1895 he once again led the insurgent troops and is credited with defeating the Spanish forces under Colonel Zbikowsky at Los Negros. In 1896 Rabí was named Major General and fought alongside García until the peace in 1898. Jose Martí wrote of Rabí's leadership during the war and his efforts were also lauded by the Americans. José Martí, José Martí: Selected Writings, translated by Esther Allen, contributor Roberto González Echevarría (New York:

Penguin Classics, 2002), 397, 407, 412. One account by an American participant in the War credits Rabí and 500 of his troops with keeping the Spaniards occupied during the U.S. landing in Santiago. “Cuba’s Fight to be Free,” New York Times, January 4, 1896.
} 
By the mid-1950s Cuba was in a state of crisis, rocked by as much political, economic, and social instability as during its first decade of nationhood. ${ }^{10}$ U.S. organized crime, in partnership with the government of President Fulgencio Batista, enjoyed revenues from payoffs and bribes totaling in the millions of dollars. ${ }^{11}$ Batista relied heavily on his cut from gambling profits and on corrupt officials and police officers who used bribery and extortion to fill their pockets. Nationally, problems with labor and a falling standard of living further undermined the economic and social structures. Most Cubans perceived themselves worse off in the 1950s than they had been in 1920. Civil protests erupted, drawing on the Cuban people's "social frustration, economic loss, and political anger."12

The U.S. descriptions of Rabí, however, offer some interesting insight into U.S. public opinion. Rabí is variously described as (1) being "of the same mixed [Indian, white, and black] blood as the Maceos"; (2) as a striking-looking Negro chieftain, and (3) perhaps most interestingly, in a post Plessy vs. Ferguson society, as a brave "Indian." For his decades of service, General Jesús Sablón“Rabí,” received \$19,000 pesos in army pay and a post as "forest inspector." Rabí died in Bayamo in 1915, having witnessed the birthand bloody demise - of the Partido Independiente de Color mostly from the sidelines. Helg, Our Rightful Share, 127, 129.

${ }^{10}$ Pérez, Between Reform and Revolution, 295.

${ }^{11}$ During the 1950s, Batista's corrupt government courted U.S. mobsters such as Meyer Lanski to invest in Cuba's open economy. Before long the "Mob" owned the biggest luxury hotels and casinos in Havana and was instrumental in sparking Cuba's tourist boom in the 1950s; for a discussion of the Batista-Lansky connection see Meyer Lansky, see Robert Lacey, Little Man. Meyer Lansky and the Gangster Life (Little, Brown \& Company, Canada, 1991). For a pictorial journey through 1950s Havana, Peter Morruzzi, Havana Before Castro: When Cuba was a Tropical Playground (Layton, Utah: Gibbs Smith, 2008). A thorough treatment of the impact of tourism on Havana economy and society from the 1920s to the 1960s, see Schwartz, Pleasure Island. For a discussion of Cuban economic issues in the 1950s see, Geoff Simons, Cuba: From Conquistador to Castro (New York: St. Martin’s Press, 1996), 211, 263; and Raúl M. Shelton, Cuba y su cultura (Miami: Ediciones Universales, 1993), 205-11, 351.

${ }^{12}$ For union problems during the 1950s, see Pérez, Between Reform and Revolution, 300-303. It was during the 1951 funeral of the leader of Cuba's Orthodox 
On 7 January 1951, Bohemia carried an extensive photo-spread of recent murders in the barrio Colón (the new San Isidro), where a drug-dealing chulo had been murdered. The story included a photo of the dead man, the angle reminiscent of the sketch of Lotot with a bloodied face lying on a morgue slab that was published in Havana papers in 1910. The magazine lauded police action in breaking up the vice and drug cartels that were entrenched in Colón. In the opinion pages of the magazine, university professor Francisco Carone philosophized that "prostitution was as old as humanity, and satiated many primordial social, economic, and even doctrinal needs; it also carried consequences-including the existence of chulos.” In the same article, Cardinal Arteaga of Havana publicly commended government officials of the Secretaría de Gobernación for having “attacked the empire of corruption and vice, [and] for turning off all the 'red lights' of moral infection. It is what Cuba expects." ${ }^{\text {13 }}$ He applauded them for finally passing a new resolution that forbade the creation of new "zonas" in the republic. At least the "evil" had been contained if not eliminated.

Little actual change was enacted in Havana as a result of the crackdown in the 1950s. With money from U.S. organized crime and with the protection of Batista’s corrupt officials, Havana became an international center for legalized vice. Drugs, gambling, pornography, and prostitution flourished at unprecedented rates. By 1958 there were 270 party, Eduardo Chibás, who shot himself in the stomach during a live radio broadcast, that a young University of Havana student named Fidel Castro jumped on the man's grave and delivered an impassioned speech denouncing the corruption of the government. The impromptu funeral of Chibás has been likened to that of Yarini.

${ }^{13}$ Manuel de J. Zamora, "Hasta donde llegara la acción de la policía en el barrio Colón?” Bohemia, 7 January 1951, 68-74; Jorge Mañach, "La decadencia del pudor,” Bohemia, 7 January 1951, 49. See also Fernández-Robaina, Recuerdos secretos, 43, 53. 
brothels in Havana and more than 11,500 women engaged in prostitution. ${ }^{14}$ The growth of the industry was noted in an editorial published by El Mundo on 15 March 1956: "The famous barrio Colón, whose ambience was provided by two or three streets, has so grown in these last few years, that it is now impossible to clearly establish its limits ... it now borders on the most elegant and luxurious commercial establishments ... conducting its business with unprecedented civility." ${ }^{15}$ The editorial also criticized lax enforcement and control by the police but stopped short of citing complicity. ${ }^{16}$ Advertisements such as those that appeared in Información in January 1958 lured women to the trade with promises of high profits: "Wanted, young women with a pleasant appearance for the new Happy-Land Club . . . Salary \$90. Plus, commission and good tips." ${ }^{, 17}$ Another advertisement published in December of that same year had similar enticements, but particularly requested that rural girls apply for work at the Centro Bar; the ad included

${ }^{14}$ Pérez, Between Reform and Revolution, 392-93. The population of Havana province had tripled between 1907 and 1953, growing from 538,000 to 1.5 million inhabitants; the percentage of the population of the island living in the province had remained stable at about one-fourth: 26.3\% in 1907 and 26.4\% in 1953. Prostitution, however, had experienced a decrease in brothels but a dramatic increase in the number of prostitutes to 11,500; dramatic, even if the 1902 figures of 744 for the city were vastly underreported. Luzón, Economía, poblacíon y territorio en Cuba, 83. Alain Corbain argues that the decline in brothels and the growth of independent practitioners was not the result of police measures, but rather a change in patterns of male sexual desire that resulted from socio-economic change. (Other historians, such as Jill Harsin, argue that the decline of the enclosed brothel was the result of changing policing practices.) Alan Corbain, Women for Hire: Prostitution and Sexuality in France after 1850, translated by Ann Sheridan (Cambridge: Harvard University Press, 1990). 1951.

${ }^{15}$ Quoted in Fernández-Robaina, Recuerdos secretos, 61; and Bohemia, 7 January

${ }^{16}$ El Mundo, 15 March 1956.

${ }^{17}$ Información, 1 January 1958, cited in Fernández-Robaina, Recuerdos secretos, 71 . 
appropriate bus routes to the bar. ${ }^{18}$ On the streets, solicitation was commonplace. Arthur Schlesinger, Jr. recalled that U.S. citizens, in Havana for a big weekend of carousing, "reeled through the streets, picking up fourteen-year-old Cuban girls and tossing coins to make men scramble in the gutter."19

A significant difference separated the 1950s from the 1910s, however, at least in the view of the working class community of Havana. There was no Yarini to protect them from abuse, to bail them out of jail, or to influence and bribe politicians. In the 1950s, no pimps emerged who were described as "honorable," only as exploitive. ${ }^{20}$ Prostitutes did not stay within their "status" and fleteras were everywhere. Foreign, especially U.S., capitalist interests, and not the "community” ruled in barrios such as Colón. The resulting anxieties and conflicts echoed the tension between foreigners and Cubans, politicians, laborers and the police during the 1910s.

It was during the disenchantment of the 1950s that Cuban playwright Carlos Felipe made the much discussed personage of Alberto Yarini the title character of what was to become his most famous play, Réquiem por Yarini, published in 1959. First performed in 1960 and "lovingly dedicated to my people of the barrio of San Isidro," Felipe wrote Réquiem between 1955 and 1959, when with the "Triumph of the Revolution" in December 1958,

\footnotetext{
${ }^{18}$ Ibid.

${ }^{19}$ Quoted in Pérez, Between Reform and Revolution, 305.

${ }^{20}$ Bohemia, 7 January 1951.
} 
there followed still another period of dramatic political, social, and economic change for Cuba. $^{21}$

Felipe's body of work was characterized by one critic as "a constant criticism, explicit or suggested, of [Cuba’s] sociopolitical reality controlled by ... insatiable plutocrats."22 Invariably, the playwright portrays powerful elites in a negative light. Perhaps Felipe's most important contribution to Cuban theater, however, was to provide a uniquely Cuban flavor to his plays, depicting scenes set close to the harbors of Havana. "No [Cuban] dramatist,” noted José Escarpenter and José Madrigal in their critique of Felipe’s works, "has been able to portray more eloquently the transfigured and fantasy world of the Havana wharfs, where with rare articulation the vestiges of a colonial past, perpetuated in stone, mates with the cosmopolitan steam of foreign seaborne business." ${ }^{23}$ In particular, Réquiem is singled out as Felipe’s most important and most “Cuban” play. Two themes that appear often in Felipe's plays are prevalent in Réquiem: the search for happiness and the recovery of the past. In the San Isidro brothel, setting for the action, Felipe's

${ }^{21}$ Carlos Felipe, Réquiem por Yarini, was published in 1960 and first performed in Havana by the Conjunto Dramático Nacional in 1965 (Carlos Espinosa Domínguez, dir., Teatro Cubano Contemporáneo: Antología (Madrid: Fondo de Cultura Económica, 1992), 195. Requiem was later adapted for the stage as a musical tragedy in the 1990s as “La Vida en Rosa.” La Vida en Rosa, adapted by Raquel Carrio y Flora Lauten, Teatro Buendia, 1999; (http:wwwteatronacional.com.do/revista/ octubre99/cuba.htm; accessed 7 February 2001. A film version of Requiem was produced in 2001 by cinematecacubana. The play was later produced as a film; Written and directed by Ernesto Daranas "La Vida en Rosa,”, Teatro Buendía (Havana), Hemispheric Institute Digital Video Library, NYU Libraries, http://hidvl.nyu.edu/video, accessed 15 August 2010.

${ }^{22}$ Felipe in Escarpanter and Madrigal, Carlos Felipe, 22.

${ }^{23}$ Escarpanter and Madrigal, Carlos Felipe, 24. 
characters try desperately to relive the past only to find that happiness, through its chimerical changes, eludes them.

Although not a biographical work, Réquiem por Yarini is set in San Isidro on the night of 21 November 1910 and the action parallels the events of that night. The interior spaces are those of a brothel of the district, and are described as clean, decorous, and wellappointed making it what the stage directions call “an extraordinary place.”24 Its main characters include Alejandro Yarini, "king of the proxenetas in Havana”; La Jaba, Yarini’s mulata manageress who is totally dedicated to him; Luis Lotot, French pimp and Yarini’s rival; Bebo la Reposa, a priest-like character who practices santeria; La Dama del Velo (the Lady of the Veil), a mysterious veiled figure from outside San Isidro (reminiscent of recollections of the real-life La Johly); la Macorina, the beautiful (but dead) Queen of the prostitutes; and the contested Santiaguera, a prostitute for whose love Yarini is ultimately killed. ${ }^{25}$

\footnotetext{
${ }^{24}$ Carlos Felipe, Réquiem por Yarini: Drama táagico en tres actos de Carlos Felipe (Miami: Ediciones Calesa, 1978), 10.

${ }^{25}$ In Réquiem the author changes the protagonist's first name from Alberto to Alejandro. If Felipe is consciously trying to create a myth in the style of the ancient Greeks, this change could be meant as an allusion to Alexander the Great or at least to a Grecian mythological counterpart. "La Macorina” was Havana’s most famous prostitute, plying her trade in the early decades of the twentieth century, but after Yarini's time (Felipe portrays her as having lived before Yarini.) She has been immortalized in poems, such as Alfonso Comin's "La Macorina," and in popular songs like "Ponme la mano aquí Macorina” (Put your hand here, Macorina.) Disfigured in a car accident, and left destitute, she lived out her life in obscurity in a small apartment on Jovellar Street in Habana; Escarpanter and Madrigal, Carlos Felipe, note no. 81, 60; Editorial, El Nuevo Herald, Miami, FL, 10 January 1983.
} 
As was the case in the real barrio, Felipe’s San Isidro is a closed system where values are inverted in relation to the outside world. Yarini's fictional barrio is a microcosm where order reigns, where every member knows his/her function, with no racial tensions, all carefully administered under the efficient tutelage of the mulata, La Jaba. "My business is order," declares Yarini in the play, "I have rules that my interns must know and respect.” Within that "pure universe of negative values,” the beautiful and seductive Santiaguera, who is deeply in love with Yarini, represents disorder. ${ }^{26}$ It is because of her that the great lord of the pimps is murdered, a victim of disorder. He is a prisoner of love, just like la Santiaguera, and because of it dies at the hands of his rival, Lotot, whom la Santiaguera had abandoned. In this case, “disorder . . . leads to death.”27

Felipe characterizes Yarini as a politician, a gambler, and a pimp, but also as possessing transcending allure that cuts across race and class. For example, La Jaba’s opening dialogue expresses her adulation for Yarini: "Yarini the politician means nothing; Yarini the gambler is no big deal . . . but Yarini the chulo ... Yarini the chulo is the King! I would have conquered the world for him, and it would not have been enough; he deserves much more.”28 This description, however, also sets up the supernatural image of the man. In Réquiem, pimping and prostitution are shown not as a social evil, but as an activity with religious overtones. Bebo La Reposa acts as a sort of santería pastor of the

\footnotetext{
${ }^{26}$ Escarpanter and Madrigal, Carlos Felipe, 40.

${ }^{27}$ Ibid., 41.

${ }^{28}$ Escarpanter and Madrigal, Carlos Felipe, 26-27.
} 
San Isidro congregation. ${ }^{29}$ He uses the caracoles (snails) to predict Yarini's death, yet is powerless to prevent it. Yarini's ñañigo ties are alluded to throughout the play and the action is permeated with images of santería, as the characters in the play call upon Changó and Eleguá, gods of the Yoruba pantheon, for help. ${ }^{30}$ For example, when Yarini's death is predicted, all the practitioners of Afro-Cuban religion on the island intercede before their gods with prayers on Yarini's behalf. Many disparate entities of Cuban society could rally around Yarini. In San Isidro, Yarini was a king; for his “interns,” a god; men imitated his dress and his mannerisms; la Santiaguera rendered him homage. There is another dimension, the veiled adulation of the gente decente. In Réquiem, the Lady of the Veil, represents Yarini’s fame outside of San Isidro, beyond prostitution and the "Zone."31 A woman of high society who wants to meet Yarini out of curiosity, in Réquiem she speaks of Yarini as the talk of all Havana. She is enthralled that he generated great curiosity and admiration among high society and his dress and style were mimicked by men in all social circles. ${ }^{32}$ "They tell me," muses la Dama, "that he is the handsomest man in Havana. And he is; and I know men ... the danzón [Cuba's sensuous national dance] was invented for [Yarini]."33

${ }_{29}$ Santería is more palatable as a group belief as opposed to the mystique and nuances of ñañiguismo.

${ }_{30}$ Escarpanter and Madrigal, Carlos Felipe, 48.

${ }^{31}$ González, “La cultura popular,” 32.

${ }^{32}$ Ibid., 41.

${ }^{33}$ Felipe, Réquiem por Yarini, 45; and Wright, Cuba, 61. 
Two explanations have been suggested for Felipe's use of Yarini as the hero of this tragedy. The first deals with the mentalite of the Cuban people. A combination of the island's sensuality and Iberian machismo generated the admiration of society for an individual like the historic Yarini: young, handsome, seductive, with potent sexual attributes, intelligent, and self-assured, who "in his short life apparently enjoyed life to the fullest, and made the most beautiful women of his time enjoy it also., ${ }^{34}$ In his controversial analysis of the Latin American "public man," Glen Caudill Dealy argues that "public virtues such as grandeur, generosity, and manliness are useful because they help in the aggregation of followers and it is this which makes them virtues. ${ }^{35}$ The second explanation is based on Felipe's socio-historical commentary of what he perceives as the Cuban reality. In the play, the anarchy and political scandals of Cuba are described as "an era of dust and mud." ${ }^{36}$ Those, not prostitution, were regarded as the truly divisive and demoralizing forces of Cuban society. For Felipe the Cuban republic was an ambivalent creation, the sum of decades of corruption wrapped in grandiose words. This then is reflected in the microcosm of Réquiem's San Isidro where the only honor and order are found among pimps, prostitutes, and santeros.

Réquiem por Yarini has often been described as the embodiment of Cuba’s first national myth under the structure of the classic Greek tragedy. Yarini is the play's tragic hero who makes a mistake in judgment and struggles against forces more powerful than he

\footnotetext{
${ }^{34}$ Escarpanter and Madrigal, Carlos Felipe, 48.

35 Dealy, The Public Man, 41.

${ }^{36}$ Felipe in Escarpanter and Madrigal, Carlos Felipe, 48-49.
} 
(love and government); ultimately, however, he achieves more than temporary mortal power and instead finds the long sought love, honor, and order only beyond the grave. ${ }^{37}$

He was not of this world. Felipe wrote that "the Cuban artist should create his [her] own myths. With Yarini I think that I have created a myth about a person who has become legendary in San Isidro.”38 In an unintended way, Yarini was already a legend that only needed codification.

In the Catholic Church, a requiem is a mass for the dead or the music for such a mass; its less used definition is that of rest, quiet, or peace. Through Felipe’s words and characterization in Réquiem por Yarini, the legendary pimp found a kind of "rest;" he emerged from the world of rumor and innuendo and became a part of Cuba's mainstream culture. $^{39}$ To possess San Isidro was to posses the heart and soul of Havana. Thus,

${ }^{37}$ Escarpanter and Madrigal, Carlos Felipe, 49.

${ }^{38}$ Felipe, quoted in González, “La cultura popular,” 23.

${ }^{39}$ During the last two decades, Réquiem was produced several times in Madrid, New York and Miami and at least twice on the Cuban stage. In Miami, the play was produced in November 1984, October 1990, and, most recently, in June 1998 and was scheduled to open in Madrid and Havana later that year as part of the Festival Internacional de Teatro Hispano. El Nuevo Herald, 27 November 1984; 25 October 1990; and 4 June 1998. Although addressing themes of prostitution and Afro-Cuban religion, both themes opposed by Fidel Castro's revolutionary ideology, the production was well received in Cuba and critics lauded what they perceived as its moralistic themes: the young republic was corrupt and engaging in prostitution carries severe consequences. In 1986 Graciela Guzmán, entertainment reporter for Bohemia, noted in her review that Réquiem revealed the problem of "corruption and opportunism of that period ... the erotic and passionate world with a creole essence, that now has found expression in new ways to enhance our development.” Graciela Guzmán, "Irrumpe Yarini," in Bohemia (Havana), 5 September 1986. In another review, published in Trabajadores, the "workers" magazine of Cuba's Communist Party, the first decades of independence are described as a "pseudo-republic" where "pseudo morals" prevailed. Mercedes Santos Moray, "Réquiem por una puesta,” Trabajadores , 15 May 1980. Thus, Yarini served to validate Revolutionary propaganda in Cuba some seventy years 
Yarini was the mythic prototype whom many wanted to imitate and who embodied a "pure” cubanidad. In Réquiem, as in real life, Yarini’s death was necessary to transform him into something larger than life, a myth that could transcend the confines and ambivalence of race, class and culture in Cuba. ${ }^{40}$ Yarini became a sacrificial victim for the government, for his profession, and for his country. ${ }^{41}$ Felipe ends the play with, "Rest in peace, Yarini. ${ }^{, 42}$

It was unlikely that Yarini would ultimately rest in peace. Having been called upon in 1959 as a representative of elusive cubanidad, in 1964 a second dramatic work based on the life and death of Alberto Yarini was published in Havana. El Gallo de San Isidro, by Jose R. Brene, however, did not receive the acceptance and accolades of Felipe’s portrayal. In El Gallo the events of 21 November 1910 are also the focus, but Alberto Yarini is characterized as a shrewd politician who is "working" the barrio. His largess is explained as a politician's ploy to win votes. In the play, one of the pimps boasts that "Cuba has produced the best pimps in the world, rum, sugar, tobacco, and pimping, in these no one can best [the Cubans]." The play's second act hinges on the phrase "Cuba

after his death. Interestingly, one of the best documented developments of the 1980s and 1990s in Cuba is the proliferation of prostitutes in the tourist sectors of Havana. One jinetera, as prostitutes are known in Cuba at present, complained that they "are living in a time of no kindness. That doesn't exist here. Everywhere there is envy, and people value things that are not true, and everyone is selfish now, and it is very scary in my heart ... everything in the country is for sale. There is no moral center to life now." Lynn Darling, “Havana at Midnight,” Esquire, May 1995, 96-106.

${ }^{40}$ González, "La cultura popular,” 43-45.

${ }^{41}$ Ibid., 45.

${ }^{42}$ Felipe, Réquiem por Yarini, 65. 
for Cubans" and implies that Yarini somehow betrayed that ideal. ${ }^{43}$ The ambivalence of memory was evident as the Castro Revolution appropriated Yarini for its own purposes in denigrating the pre-revolutionary "republic.” The public, however, continued to demand productions of Réquiem, which within a few years were staged in Madrid, Havana, New York and Miami numerous times.

\section{Myths and Memory}

The Yarini legend continued to grow; and in the twenty-first century he has reached mythical proportions within popular Cuban culture and imagination. Since the 1960s, there have been many adaptations and appropriations of Yarini's story. A film version of Réquiem was produced in 2001 and the play was also transformed into the "Ballet Yarini,” performed in Havana in 2006 at the Federacion Estudiantial Universitaria. ${ }^{44}$ Yarini has been the subject of popular songs such as "Un chulo en la Habana," a soncubano tribute to Yarini's larger than life persona. ${ }^{45}$ He has served as inspiration for

${ }^{43}$ José R. Brene, El Gallo de San Isidro (Havana: Ediciones R., 1964), Act I.

${ }^{44}$ Requiem por Yarini, Cine Internacional Production, 2001; Martha Sánchez, “Laura Alonso, maestra de todos” Cubasi.com (online journal), http://www.cubasi.cu/desktopdefault.aspx?spk=160\&clk=44485\&lk=1\&ck=22372\&spka =35, accessed 28 January 2007.

45 Jóvenes Clásicos del Son, “Un Chulo en la Habana,” in Fruta Bomba, Tumi Music Ltd. (2006). Another Cuban band, Tesis de menta, produced a Yarini-themed album with titles such as "The man with Money," "Diary of a Look," and "Yarini, 1910," Juventud Rebelde, 4 May 2005. The son cubano, is a uniquely Cuban style of music that originated in the eastern provinces of the country in the late nineteenth century and reached Havana by 1910 . The Son sound, which incorporates elements of the traditional Spanish canción with African rhythms and the use of percussion instruments, became popular worldwide during the 1920s and 30s. After the Cuban Revolution of 1959, a new form of Son, the salsa, has become one of the most recognized and popular Latin music styles in the world. Robin Moore argues that Son provided a form of expression for Afro- 
telenovelas and countless stories in the popular press, with little attention given to the integrity or authenticity of the "facts." Recently, Miguel Angel Sabater published, Flores para una leyenda, a novel about the incalculable power of friendship using Yarini as its hero and the relationship with Bastarrechea as plot. ${ }^{46}$ In 2006, Come so Far from Havana, an autobiographical account, hit the bookstores, its author was promoted as a “descendant of Alberto Yarini, the famous gigolo in Cuban history.” Unfortunately for the credibility of the author, Yarini had no legal offspring. ${ }^{47}$ The latest adaptation of Yarini's tale is Los Dioses Rotos, a prize-winning film about a university professor who in researching the life and death of AlbertoYarini and becomes entangled in a modern day web of intrigue and murder in San Isidro with many parallels to the real life story of Yarini. It provides a contemporary rendition of the ability for a modern-day Yarini to

Cubans that was palatable to white Cubans. She credits the acceptance of musical expressions such as the Son with providing a gateway for other forms of integration of Afro-Cubans into mainstream Cuban culture. Robin Moore, "Afrocubanismo and Son," The Cuba Reader: History, Culture, Politics, Aviva Chomsky, Barry Carr, Pamela María Smorkaloff, eds. (Durham: Duke University Press, 2004), 192-99.

${ }^{46}$ Miguel Ángel Sabater, Flores para una leyenda (Havana: Union de Artistas, 2005). The protagonist/narrator in this novel is a historian who visits Yarini's grave.

${ }^{47}$ Joseph R. Yarini, Come So Far From Havana (Portland: Inkwater Press, 2006). The Amazon.com description reads "Memoirs of Joseph R. Yarini,son of Raul Yarini and descendant of Alberto Yarini, the famous gigolo in Cuban history. In 1960 'Raulito' was forced to leave his country and the people he loved to avoid persecution, oppression and communism. In contrast from others that left the lost island and kept with their customs, traditions and language, he chooses to forget - that is until now! After landing in Miami with nothing but his name, he worked hard, joined the Army, fought prejudices, became a family man, built a business, became a racecar driver, found faith and was touched by God's spirit. Adversities couldn't defeat him!" http://www.amazon.com/Come-FarHavana-Joseph-Yarini, accessed 15 August 2009. 
navigate all the racial and social strata of Havana. According to the film's producers, Dioses is a story that is "universal and important." 48

\section{Conclusion}

In Foundational Fictions, an analysis of Latin American fiction in the nineteenth and early twentieth centuries, Doris Sommer argues that during those decades, "romance and republic were often connected . . [ [novels] fueled a desire for domestic happiness that [ran] over into dreams of national prosperity; and nation-building projects invested private passions with public purpose." ${ }^{49}$ Perhaps for a newly independent Cuba, Yarini provided a similar image. In 1986, a Cuban theater critic described Yarini as "a wellknown character in his time, and not because of his great merit exercised in our historic development, on the contrary, because he was one of the most celebrated pimps of neocolonial Havana at the dawn of the twentieth century, a city and era of contrasts, where everything or nothing could happen." ${ }^{, 0}$ It was precisely because he could successfully navigate between the contradictory spheres of Havana's social and political strata, however, that Yarini emerged as a cultural icon for Cuba, embodying the coalescence of elite and popular conceptions of patria and cubanidad. The negative aspects of his life his criminal past, run-ins with the law, pimping, racketeering, and violence-are translated into heroic feats with grandiose motives by the collective memory of a nation.

\footnotetext{
${ }^{48}$ Ernesto Daranas, writer/director, Los Dioses Rotos (Havana: ICAICMINCULT, 2008), http://www.cubacine.cu/losdiosesrotos, accessed 15 August 2010.

${ }^{49}$ Doris Sommer, Foundational Fictions: The National Romances of Latin America (Berkeley: University of Califormia Press, 1993), 7.

${ }^{50}$ Guzmán, “Irrumpe Yarini,” 25.
} 
Social bandits, Eric Hobswam proposed, are a universal phenomena. Bandits were criminals who were regarded as the people’s heroes, avengers, fighters for justice. Sometimes they were seen as liberators, but always admired and supported for their beneficence to the common people and their defiance of the establishment. ${ }^{51}$ Yarini, however, represented a new version of Hobswam's social bandit. He was not a rural commoner, as are most social bandits, but rather an elite politician, a new kind of Robin Hood who was seen as having the power, money, and connections to right what was wrong with Cuba. ${ }^{52}$ It did not matter if he had not been able to do it—only that he could. He transcended class, race and gender and was the needed representative for an emerging identity. ${ }^{53}$

Throughout the last one hundred years, Yarini remained fixed in the collective memory of habaneros. It was not socially acceptable to admire Yarini openly, unless one was a member of the prostitution community, but his prowess made him a sort of hero for many

${ }^{51}$ Hobsbawm's thesis posits ordinary people (rural) as heroes and as symbols that rally those who feel oppressed and labeled it a "pre-historic social movement." Eric Hobsbawm, Bandits, Revised Edition, (New York: New Press, 2000). See also Graham Seal, "The Robin Hood Principle: Folklore, History and the Social Bandit," Journal of Folklore Research 46, no. 1 (January-April, 2009): 67-89.

${ }^{52}$ In the United States during the 1920s and 30s, Al Capone was viewed by many as a modern-day Robin Hood. Capone had moved to Chicago. In his early twenties he moved to Chicago and made a fortune as a smuggler during Prohibition and engaged in various other criminal activities, including bribery of elected officials and prostitution. Capone used money from his criminal activities to open soup kitchens for the Chicago's poor, lobbied for laws to date milk bottles to safeguard children, and made regular appearances at city hall. His reputation dwindled in the public eye after his extended incarcerations and multiple charges of murder, John Kobler, Capone: The Life and World of Al Capone (New York: DaCapo Press, 2003).

${ }^{53}$ Graham Seal, "The Robin Hood Principle: Folklore, History and the Social Bandit,” Journal of Folklore Research 146, no.1 (January-April, 2009), 68. 
Cuban men who imaged themselves to be like him, the most "public" of men. In a society where reputation and connections were all-important, he was the god of the double standard; Yarini acted in the open, not caring about what others thought. His memory long survived through gossip and popular stories only to be openly resurrected by Carlos Felipe at the close of the 1950s. When the play was published it validated in print the gossip and stories that reportedly had been much discussed in Havana for many decades..$^{54}$

What had made the Yarini story endure? Yarini the patriot, Yarini the socialite, and Yarini the pimp coexisted with dignity in a Cuba that was muddied by its attempts at nation building. Politicians capitalized on the powerless, and their moralization campaigns were criticized by Felipe’s mulata madam, la Jaba, as the "moralizing of [politician's] pockets, full of scruples without risks." ${ }^{\text {,55 }}$ In the midst of such corruption and graft, Yarini’s most important quality was honor; his ordered "regulations” for San Isidro, his patriotic comportment, his beneficence, and even his deathbed confession, made him respected and admired; all else could be forgiven or forgotten. While after his death some said that he had been mad, to others the 28-year-old martyr of San Isidro became a unique symbol of nascent cubanidad. Thus, the politics of nation-building created a truly Cuban "hero," who was also very human; not a hero crafted by elites for international interests, but one hand-picked by the common people.

\footnotetext{
${ }^{54}$ Fernández-Robaina, Recuerdos secretos, 34.

${ }^{55}$ Felipe, Réquiem por Yarini, 19.
} 
Much as Venezuelan President Húgo Chávez did in September 2010 when he exhumed Simon Bolivar's bones, announcing he wept with emotion when he saw the skeleton, Yarini has been exhumed by Cubans in times of psychological need: in the chaos of the decade of the 1950s when the renewed hope of 1940 had faded, and at the beginning of the new millennium with the possibility of a new regime. ${ }^{56}$ Mired in ambivalence, Cubans had not been able to achieve national consensus about cubanidad: politics had not worked; North American models that had served other countries well had not worked. Instead, a nation’s public dreams lay shattered.

While the heroes of independence and the intellectual giants that followed found their way into the history books, Yarini found a place in Havana's collective consciousness. It was not socially acceptable to admire a man like Yarini openly, unless one was a member of the lower classes, but his accomplishments made him a symbol for a new nation desperately trying to establish its identity. The assassination (or murder) of Yarini merely provides a prism through which to view issues of Cuban national identity. The murder catalyzed a seemingly odd convergence of Havana elites, underworld figures linked to prostitution, and the social and cultural layers in between. The confluence of class, race, and culture displayed the ambivalence that was - and some argue-remains a fundamental characteristic of Cuban national identity. This study proposes that Cuban national identity — cubanidad — was the product of a nativist counterculture that contested elite nationalist discourse. The romantic version of Yarini was the embodiment of that developing consciousness.

${ }^{56}$ “Chavez's obsession with past turns creepy -- and he's not alone,” Miami Herald, 11 September 2010. 
History, however, should act as a function of memory and strive for objectivity. ${ }^{57}$ This thesis presents the factual history of Yarini and his elevation to mythological hero and urban legend. Three characteristics of the evolution of the Yarini story reinforce its mythical status. First, as with most myths, Yarini’s story has taken decades to coalesce and will no doubt continue to evolve as part of a Cuban identity. In The Hero with a Thousand Faces, Joseph Campbell proposes that there are no new stories for people to tell, but that the retelling of familiar stories in new ways creates a sense of belonging to the group and identification with the hero. ${ }^{58}$ Second, national myths often inform national identity by creating “common shared heroic aspirations as focal points that people can rally around.”59 The transient nature of a myth allows it to accommodate new realities easily and, as in the case of Yarini and the countless retellings of his story, a society can deliberately distort or reinvent the past in view of the present. The true significance of myths, then, is not about the facts, but rather about the meaning that culture attributes to those myths. ${ }^{60}$ Third, the created mythology of nations often owes a great deal to those who died in their defense. While traditional heroes and heroines probably died in combat in the defense of country, nevertheless, heroes can take on many forms. Yarini defended his country and the honor of his countrymen against threats such

${ }^{57}$ Jacques Le Goff, History and Memory (New York: Columbia University Press, 1992), 99.

58 Joseph Campbell, The Hero with a Thousand Faces (New York: Meridian Books, 1956), 382-83. (This book reportedly was the inspiration for George Lucas’ Star Wars).

${ }^{59}$ Maurice Halbwachs, On Collective Memory (Chicago: University of Chicago Press, 1992), 134-135.

60 Ibid. 
as Tarler represented. Many thought he ultimately sacrificed his life in defense of his country's honor. His subsequent mythification provides a unique rubric for understanding the dynamics and ambivalence of Cuban society and culture.

\section{Epilogue}

In 1905, to honor Máximo Gómez, city officials held a special memorial service, erected a statue in the Plaza de Armas, and hung his portrait in City Hall. In 2001, there were rumors in Havana that Eusebio Leal, official historian of the city of Havana, proposed erecting a statue to Yarini as part of the restoration of Old Havana (Habana Vieja). ${ }^{61}$ The gente decente, however, vetoed the idea, all the while snatching up copies of the latest Bohemia, which featured an article entitled, "El chulo que soñó ser presidente" ("The pimp who dreamed of being president”). ${ }^{62}$ Yarini's memory survives and grows through gossip and popular stories, a kind of antitype hero for many Cubans who imaged themselves to be like him, the most "public" of men and the ultimate caudillo.

Sitting outside her home in Habana Vieja and asked if she knew about Yarini, "Carmen," a 60-something resident of San Isidro broke out in a toothless smile, “AHHH,” she replied, “el hombre áas bello que ha vivido en la Habana!”(the most beautiful man who ever lived in Havana). ${ }^{63}$

${ }^{61}$ Conversation with the author, (Havana), Tomás Fernández Robaina, 26 January 2001.

${ }^{62}$ Bohemia, “El chulo que soñó ser president,” December 2001.

${ }^{63}$ Conversation with the author, (Havana), "Carmen, on the Streets of Habana Vieja,” 27 January 2001. 


\section{LIST OF REFERENCES}

\section{$\underline{\text { Manuscript Collections }}$}

ACM Archivos de la Catedral de Matanzas (Matanzas, Cuba)

Archivo Cementerio Colon, Registro de Asentimiento

AHN Archivo Histórico Nacional (Madrid)

ANC Archivo Nacional De Cuba (Habana, Cuba)

APM Archivos Parroquia de Monserrate (Havana, Cuba)

AUH Archivos de la Universidad de la Habana (Havana, Cuba)

Ellis Island Foundation Archives (online)

LDS. Latter Day Saints Family Search International Genealogical Index, Volume 5.0, Batch Number 8768202, Sheet 06, Source 1396373.

LDS. Latter Day Saints Family Search International Genealogical Index. Volume 5.0, Batch8768202, Sheet 05, Source 1396373.

MHS Massachusetts Historical Society, Edwin F. Atkins Collection, Scrapbooks, Boston, MA. (Courtesy Sherry Johnson).

NARA. U.S. National Archives and Records Administration (Washington, D.C.) Micropublication, M259, RG036, National Archives Series T905-4, Passenger Lists of Vessels Arriving in New Orleans Louisiana, 1903-1945.

NARA II. U.S. National Archives and Records Administration (College Park, MD.) Microfilm, Series M862. Cabinet 43/5-45/3, Roll 907 (Sept. 1908). File group 14963. U.S. Department of State Numerical and Minor File 1906-1910.

Registro de Estado Civil de Norte Habana. Sección de Defunciónes. "Certificado de defunción de Alberto Yarini,” Tomo 13, Folio 291.

\section{$\underline{\text { Newspapers }}$}

The American Friend (Philadelphia)

Bohemia (Havana)

Chicago Daily News Almanac and Yearbook 
Diario de Cuba (Havana)

Diario la Marina (Havana)

Daily Telegraph (Havana)

El censor: Periódico político y literario (Madrid)

El Comercio (Havana)

El Mundo (Havana)

El Nuevo Herald

El Triunfo (Havana)

Gaceta Oficial de la Republica de Cuba (Havana)

Havana Magazine (Havana)

Havana Mañana: A Guide to Cubans (Havana)

Havana Post (Havana)

Havana Telegraph (Havana)

Juventud Rebelde (Havana)

La Cebolla, (Havana).

La Discusion (Havana)

La Lucha (Havana)

La Razon (Havana)

The New Leader

New York Times

The Pharmaceutical Era (New York)

Prevision (Havana)

Tampa Tribune

Trabajadores (Havana) 
The Quaker Weekly (Philadelphia)

Washington Post

Magazine Articles

“The Freedom of the Press.” Public Opinion, 18 April 1901.

Mauricio Vicent, “Castro sufre una lipotimia durante un mitin televisado en directo.” El País, 24 June 2001.

Nelson del Castillo, “Castro 'lamenta’ que enemigos no celebraran con ron y whisky,” El Siglo, 25 June 2001.

Weightman, Gavin. "Was it British? Social Analysis of Public Grieving Rituals in Great Britain.” History Today, November 1997, 6-7.

\section{Government Documents}

Comisión de Higiene Especial. Reglamento de la prostitución en la ciudad de La Habana. Havana: M. Pulido, 1899.

Decreto No. 883. Gaceta Oficial de la Republica de Cuba. 4 October 1912, 4014.

Decreto No. 964. Gaceta Oficial de la Republica de Cuba. 23 October 1913, 53-54.

Fourteenth Census of the United States Taken in the Year 1920, Population 1920.

Washington D.C.: Government Printing Office. Cited in "Yarini Family Search," ancestry.com. Accessed 14 August 2010.

Gorgas, William Crawford. Report of Major William Crawford Gorgas, Chief Sanitary Officer of the City of Havana. Havana, Headquarters Dept. of Cuba, Office of Chief Sanitary Officer of Havana, 1900.

Magoon, Charles. Reporte de la administración provisional, desde 1 diciembre de 1907 hasta el 1 de diciembre de 1908. Havana: Rambla and Bouza, 1909.

Rebello, Carlos. Estados relativos a la producción azucarera de la isla de Cuba, formados competentes y con la autorización de la intendencia del Ejercito de Hacienda. Havana: Imprenta del Gobierno, 1860.

Reglamento de la ley de inmigración y de las trata de blancas. Havana: Imprenta y Papelería de Rambla, Bouza, y Cía., 1925.

Secretaría de Gobernación, Decreto No. 1158, Gaceta Oficial de la Republica de Cuba, 27 December 1911, 6653. 
United States Congress Committee on Relations with Cuba. Statement of revenues and expenditures in Cuba: as shown in auditor's statement of accounts current in May and June,1900, and supplementary accounts from date of American occupation to June 30,1900. June 25,1902. Washington, D.C.: Government Printing Office, 1902.

United States Department of War. Report on the Census of Cuba, 1899.

Washington, D.C.: Government Printing Office, 1900.

. Report on the Census of Cuba, 1907. Washington, D.C.: Government Printing Office, 1908

. Report on the Census of Cuba, 1919. Washington, D.C.: Government Printing Office, 1920.

\section{Personal Communication}

Aranda, Gisela. Conversation with the author, 2 April 1997, at Florida International University, Miami, Florida.

"Carmen,” (who refused to give her last name). Personal conversation with the author, 27 January 2001, San Isidro, Havana, Cuba.

“El Negro” Vargas. Conversation with the author, 26 January 2001, National Archives, Havana, Cuba.

Tomás Fernández Robaína. Conversation with the author, 26 January 2001, National Archives, Havana, Cuba.

Monographs

Addams, Jane. A New Conscience and Ancient Evil. New York: Macmillan Company, 1923.

Adrián Borges, Milo, ed., Compilación ordenada y completa de la legislación cubana, 1899-1950, Vol. I. Havana: Editorial Lex, 1952.

Alfonso, Ramón M. La prostitución en Cuba y especialmente en la Habana, memoria de la Comisión de Higiene Especial de la Isla de Cuba. Havana: P. Fernández, 1902.

. Reglamentación de la prostitución, breves apuntes como debe ser en Cuba. Havana: A. Miranda, 1912.

Anderson, Benedict. Imagined Communities: Reflections on the Origin and Spread of Nationalism. New York: Verso, 1991.

Armstrong, Karen. A Short History of Myth. New York: Canongate, 2005. 
Atkins, Edwin F. Sixty Years in Cuba: Reminiscences of Edwin F. Atkins. Cambridge, MA: Riverside Press, 1926. Reprint New York: Arno Press, 1980.

Attwood, Francis Gilbert. Attwood's Pictures: An Artist's History of the Last Ten Years of the Nineteenth Century. New York: Life Publishing, 1900.

Ayala, Cesar. American Sugar Kingdom: The Plantation Economy of the Spanish Caribbean, 1898-1934. Chapel Hill: University of North Carolina Press, 1999.

Bago, Eduardo Lopez. El Separatista: Novela Medico-Social: Primera Parte De Una Tetralogia. Charleston, SC: Nabu Press, 2010.

Bailey, Thomas A. The Man in the Street: The Impact of Public Opinion on Foreign Policy. New York: Peter Smith Publishers, 1964.

Balderston, Daniel and Donna J. Guy, eds. Sex and Sexuality in Latin America. New York: New York University Press, 1997.

Bell, Ernest A. Fighting the Traffic in Young Girls, or War on the White Slave Trade. Chicago: [n. p.], 1910.

Ballester, Alberto Perret. El azúcar en Matanzas y sus dueños en La Habana: apuntes e iconografía. Havana: Editorial Ciencias Sociales, 2007.

Baptist, Edward E. Creating an Old South: Middle Florida's Plantation Frontier before the Civil War. Chapel Hill: University of North Carolina Press, 2002.

Benjamin, Jules. The United States and the Origins of the Cuban Revolution: An Empire of Liberty in an Age of National Liberation. Princeton, NJ: Princeton University Press, 1992.

Bernaldo de Quirós, Constancia and Jesús María Llanas Aguilaniedo. La mala vida en Madrid: estudio psico-sociológico. Madrid: B. Rodríguez Serra, 1901.

Bethell, Leslie, ed. Cuba: A Short History. Cambridge, MA: Cambridge University Press,1993.

Boix Comas, Alberto. Así es Cuba!! Habana: Cía. Petrolera Shell de Cuba, 1955.

Bonavia, Leopoldo Fornes. Cuba, cronología: cinco siglos de historia, política y cultura. Madrid: Editorial Verbum, 2003.

Bradley, Hugh. Havana: Cinderella’s City. Garden City, NY: Doubleday, Doran and Company, 1941.

Bredbenner, Candice Lewis. A Nationality of Her Own: Women, Marriage, and the Law of Citizenship. Berkeley: University of California Press, 1998. 
Brene, José Ramón. El Gallo de San Isidro. Havana: Ediciones Revolucionarias, 1964.

Breslin, Thomas A. Rum versus Whiskey: The Great Anglo-Celtic Divide in the History of American Foreign Relations. Forthcoming.

Bryan, William Jennings. "Imperialism." In Under Other Flags: Travels, Lectures, Speeches. Lincoln, NE: Woodruff-Collins Printing Co., 1904.

Bronfman, Alejandra. Measures of Equality: Social Science, Citizenship, and Race in Cuba, 1902-1940. Chapel Hill: University of North Carolina Press, 2004.

Campbell, Joseph. The Hero with a Thousand Faces. New York: Meridian Books, 1956.

Canizares, Dulcila. San Isidro, 1910: Alberto Yarini y su época. Havana: Editorial Letras Cubanas, 2000.

Carr, Raymond. Spain, 1808-1938 . Oxford: Clarenden Press, 1966.

Casanovas, Joan. Bread or Bullets: Urban Labor and Spanish Colonialism in Cuba, 1850-1898. Pittsburgh, PA: University of Pittsburgh Press, 1998.

Castellanos, Jorge and Isabel Castellanos. Cultura afrocubana: El Negro en Cuba, 18451959. Miami: Ediciones Universal, 1994.

Castillo Bueno, Maria de la Reyes. Reyita: The Life of a Black Cuban Woman in the Twentieth Century. Translated by Anne McLean. Durham: Duke University Press, 2000.

Castro Fernández, Silvio. La Masacre De Los Independientes De Color En 1912. Havana: Editorial de Ciencias Sociales, 2002.

Caulfield, Sueann. "The Birth of Mangue," in Daniel Balderston and Donna Guy, eds., Sex and Sexuality in Latin America. New York: New York University Press, 1997.

Chapman, Charles E. A History of the Cuban Republic: A Study in Hispanic American Politics. New York: Macmillan, 1927.

Childs, Matt and Toyin Falola, eds. The Yoruba Diaspora in the Atlantic World. Bloomington, IN: Indiana University Press, 2005.

Cipriano Venzon, Anne. The Spanish American War: An Annotated Bibliography. New York: Garland, 1990.

Clendinnen, Inga. Ambivalent Conquests: Maya and Spaniard in Yucatan, 1517-1570. New York: Cambridge University Press, 2003. 
Clendening, Logan, Source Book of Medical History. New York: Dover Publications, 1960.

Collazo, Enrique. Los Americanos en Cuba. Havana: C. Martinez y Comp, 1905.

Connell, Raewyn. Masculinities. St. Leonards, New South Wales: Allen and Undwin, 1995.

Connelly, Mark. The Response to Prostitution in the Progressive Era. Chapel Hill: University of North Carolina Press, 1980.

Conte, Rafael and José M. Capmany. Guerra de Razas (Negros contra blancos en Cuba). Havana: Imp. Militar de Antonio Perez, 1912.

Crichfield, George Washington. American Supremacy: The Rise and Progress of the Latin American Republics and Their Relations to the United States Under the Monroe Doctrine, Volume 1. New York: Brentano, 1908.

Corbain, Alain. Women for Hire: Prostitution and Sexuality in France after 1850. Cambridge: Harvard University Press, 1990.

Cunliffe, Marcus. George Washington: Man and Monument. New York: Penguin, 1982.

Danero, E. M. S. El Cafishio. Buenos Aires: Fontefrida Editora, 1971.

Dealy, Glen Caudill. The Latin Americans: Spirit and Ethos. Boulder, CO: Westview Press, 1992.

. The Public Man: An Interpretation of Latin American and Other Countries. Amherst: University of Massachusetts Press, 1977.

de Céspedes, Benjamín. La prostitución en la ciudad de la Habana. Havana: Establecimiento Tipografico O’Reilley, 1888.

de Grazia, Sebastian. Machiavelli in Hell. Princeton, NJ: Princeton University Press, 1989.

de Juan, Adelaida. Caricatura en la Republica. Havana, Editorial Letras Cubanas, 1982. de la Fuente, Alejandro. A Nation for All: Race, Inequality, and Politics in Twentieth Century Cuba. Chapel Hill: University of North Carolina Press, 2001.

Delany, Martin Robison. Blake: Or the Huts of America. Boston: Beacon Press, 1970. 
de las Cuevas Toraya, Juan. 500 años de construcciones en Cuba. Madrid: D. V. Chavin, 2001.

de las Reyes Castillo Bueno, Maria. Anne McLean, trans. Reyita: The Life of a Black Cuban Woman in the Twentieth Century. Durham, NC: Duke University Press, 2000.

de la Torriente, Cosme. Cuarenta Años de mi Vida: 1898-1938. Havana: A. Muniz, 1939.

Dihigo, Juan M. La Universidad de la Habana: bosquejo histórico. Havana: Imprenta "El Siglo XX,” 1916.

Dixon, James. "Speech of the Hon. James Dixon of Connecticut, on the thirty million bill, for the acquisition of Cuba. Delivered before the Senate of the United States, 25 February 1859.” Washington: L. Towers, 1859.

Dmitriev, Svatoslav. City Government in Hellenistic and Roman Asia Minor. New York: Oxford University Press, 2005.

Dolgoff, Sam. The Cuban Revolution: A Critical Perspective. Montreal: Black Rose Books, 1976.

Draper, Theodore. Castroism, Theory and Practice. New York: F. A. Praeger, 1965. . Castro's Revolution, Myths and Realities . New York: F. A. Praeger, 1962.

DuBois, W.E.B. The Souls of Black Folk: Essays and Sketches. Chicago: A.C. McClurg and Company, 1903.

Duque, Matias. La prostitución, sus causas, sus males, su higiene. Havana: Rambla, Bouza, y Compañía, 1914.

Dye, Alan. Cuban Sugar in the Age of Mass Production: Technology and the Economics of the Sugar Central, 1899-1929. Stanford CA: Stanford University Press, 1998.

Eire, Carlos M.N. From Madrid to Purgatory: The Art and Craft of Dying in SixteenthCentury Spain. Cambridge: Cambridge University Press, 2002.

Escarpanter, José A. and José A. Madrigal. Carlos Felipe: Teatro. Boulder, CO: Society of Spanish and Spanish-American Studies, 1988.

Espinosa Domínguez, Carlos director. Teatro Cubano Contemporáneo: Antologia. Madrid: Fondo de Cultura Económica, 1992.

Espinosa, Mariola. Epidemic Invasions: Yellow Fever and the Limits of Cuban Independence, 1878-1930. Chicago: University of Chicago Press 2009. 
Estrada, Jose Alfredo. Havana: An Autobiography of a City. New York: Palgrave Macmillan, 2007

Fanon, Frantz. Black Skin, White Masks. Translated by Richard Philcox. New York: Grove Press, 2008.

. The Public Man: An Interpretation of Latin American and Other Countries. Amherst: University of Massachusetts Press, 1977.

Felipe, Carlos. Réquiem por Yarini: Drama tragico en tres actos. Miami, FL: Ediciones Calesa, 1978.

Fermoselle, Rafael. The Evolution of the Cuban Military: 1492-1986. Miami: Ediciones Universal, 1987.

. Politica y Color en Cuba: La Guerrita de 1912. Montevideo: Ediciones Géminis, 1974.

. Rafael. Black Politics in Cuba: The Race War of 1912. Ph. Dissertation, American University, 1972.

Fernández Robaina, Tomas. Historias de Mujeres Publicas. Havana: Editorial Letras Cubanas, 1998.

. Recuerdos secretos de dos mujeres públicas. Havana: Editorial Letras Cubanas, 1983.

Fernández Santalices, Manuel. Las calles de la Habana entramuros: arte, historia y tradiciones en las calles y plazas de la Habana vieja. Miami: Saeta Ediciones, 1989.

Fernández, Silvio Castro. La Masacre De Los Independientes De Color En 1912. Havana: Editorial de Ciencias Sociales, 2002.

Ferrer, Ada. Insurgent Cuba: Race Nation and Revolution, 1868-1898. Chapel Hill: University of North Carolina Press, 1999.

Foner, Philip S. A History of Cuba and its Relations with the United States, 2 Volumes. New York: International Publishers, 1963.

Font, Mauricio Augusto and Alfonso W. Quiroz. The Cuban Republic and Jose Martí: Reception and Use of a National Symbol. Lanham, MD: Lexington Books, 2006.

Fraginals, Manuel Moreno. El ingenio: Complejo económico-social del azúcar. 2 Volumes. Havana: Editorial de Ciencias Sociales, 1978. 
Gallenga, Antonio. Cuba: The Pearl of the Antilles. London: Chapman Hall, 1883.

Geertz, Clifford. The Interpretation of Cultures. New York: Basic Books, 1973.

Ginzburg, Carlo. Translated by John and Anne Tedeschi. The Cheese and the Worms: The Cosmos of a Sixteenth-Century Miller. Baltimore, MD: Johns Hopkins University Press, 1980.

Goldstein, Donna M. Laughter Out of Place: Race, Class, Violence and Sexuality in a Rio Shantytown. Berkeley: University of California Press, 2003.

Gómez, Juan Gualberto. La cuestión de Cuba en 1884, Historia y soluciones de los partidos cubanos. Madrid, Aurelio J. Alaria, 1885.

González-Ripoll Navarro, María Dolores. Cuba, La Isla de los Ensayos: Cultura y Sociedad, 1790-1815. Madrid: Centro de Humanidades, 1999.

Gott, Richard. Cuba: A New History. New Haven, CT: Yale University Press, 2005.

Grainger, Roger. The Social Symbolism of Grief and Mourning. London: Jessica Kingsley Publishers, 1998.

Guerra, Lillian. The Myth of Jose Marti. Chapel Hill: University of North Carolina Press, 2005.

Guy, Donna J. Sex and Danger in Buenos Aires: Prostitution, Family, and Nation in Argentina. Lincoln: University of Nebraska Press, 1995.

Halbwachs, Maurice and Lewis A. Coser. On Collective Memory. Chicago: University of Chicago Press, 1992.

Helg, Aline. Our Rightful Share: The Afro-Cuban Struggle for Equality, 1886-1912. Chapel Hill: University of North Carolina Press, 1995.

Hermer, Consuelo Kamholz and Marjorie May. Havana Mañana: A Guide to Cubans. New York, Random house 1941.

Hewitt, Nancy and Suzanne Lebsock, eds., Visible Women: New essays on American Activism. Urbana: University of Illinois Press, 1993.

Hildebrand, Robert. Power and the People: Executive Management of Public Opinion in Foreign Affairs, 1897-1921. Chapel Hill: University of North Carolina Press, 1981. 
Hobsbawm, Eric. Bandits, revised edition. New York: New Press, 2000.

Hoch, Paul. White Hero, Black Beast: Racism, Sexism and the Mask of Masculinity. London: Pluto Press, 1976.

Hoganson, Kristin. Fighting for American Manhood: How Gender Politics Provoked the Spanish-American and Philippine-American Wars. New Haven, CT: Yale University Press, 1998.

Holzer, Harold. The Lincoln-Douglas Debates. New York: Harper Collins, 1993.

Hunt, Michael H. Ideology and U.S. Foreign Policy. New Haven, CT: Yale University Press, 1987.

Hurewitz, J.C. The Middle East and North Africa in world politics: a documentary record. British-French supremacy, 1914-1945. New Haven, CT: Yale University Press, 1979.

Hutchinson, John and Anthony Smith, eds. Nationalism. New York: Oxford University Press, 1994.

Iggers, Georg G. Historiography in the Twentieth Century: From Scientific Objectivity to the Postmodern Challenge. Hanover, NH: Wesleyan University Press, 1997.

Isenberg, Nancy. Sex and Citizenship in Antebellum America. Chapel Hill: University of University Press, 1998

Jensen, Larry. Children of Colonial Despotism: Press, Politics, and Culture in Cuba, 1790-1840. Gainesville: University Press of Florida, 1998.

Johnson, John J. Latin America in Caricature. Austin: University of Texas Press, 1980.

Johnson, Sherry. The Social Transformation of Eighteenth-Century Cuba. Gainesville: University of Florida Press, 2001.

Johnson, Willis Fletcher. The History of Cuba, Volume 4. New York: B.F. Buck \& company, 1920.

Keuthe Alan. Cuba, 1753-1815: Crown, Military, and Society. Knoxville: University of Tennessee Press, 1986.

Kirk, John. José Martí: Mentor of the Cuban Nation. Gainesville: University of Florida Press, 1983.

Kobler, John. Capone: The Life and World of Al Capone. New York: DaCapo Press, 2003. 
Kneeland, George Jackson. Commercialized Prostitution in New York City. New York: Century, 1913.

Lacey, Robert. Little Man. Meyer Lansky and the Gangster Life. New York: Little, Brown \& Company, 1991.

LaFeber, Walter. The American Age, 2 Volumes. New York: Norton, 1994.

Landers, Jane A. and Barry Robinson eds., Slaves and Subjects: Blacks in Colonial Latin America. Albuquerque: University of New Mexico Press, 2006.

Lavrín, Asunción. Women, Feminism and Social Change in Argentina, Chile, and Uruguay, 1890-1940. Lincoln: University of Nebraska Press, 1995

Le Goff, Jacques. History and Memory. New York: Columbia University Press, 1992.

León-Portilla, Miguel. The Broken Spears: The Aztec Account of the Conquest of Mexico. Boston, MA: Beacon Press, 1992.

Lindsay, Arturo. Santeria Aesthetics in Contemporary Latin American Art. Washington, D.C.: Smithsonian Institution Press, 1996.

Londres, Albert and Eric Sutton. The Road to Buenos Ayres. London: Constable and Co., 1928.

López Bago, Eduardo. El Separatista: Novela Medico-Social: Primera Parte De Una Tetralogia. Charleston, SC: Nabu Press, 2010.

Lorini, Alessandra. Rituals of Race: American Public Culture and the Search for Racial Democracy. Charlottsville: University of Virginia Press, 1999.

Luisi, Paulina. El problema de la prostitución: abolicionismo o reglamentarismo. Montevideo: Sindicato Médico del Uruguay, 1926.

Luna, Lola G. and Norma Villarreal M. Historia, género, y política: movimientos de mujeres y participación política en Colombia, 1930-1991. Barcelona:

Promociones y Publicaciones Universitarias, 1994.

Luzón, José L. Economía, población y territorio en Cuba 1899-1983. Madrid: Ediciones Cultura Hispánica del Instituto de Cooperación Iberoamericana, 1987.

Lynch, John. Símon Bolivar: A Life. New Haven, CT: Yale University Press, 2007.

Machiavelli, Nicolo. The Chief Works and Other. 3 Volumes. Translated by A. Gilbert Durham: Duke University Press, 1965. 
Martinez-Fernandez, Luis. American Sugar Kingdom: The Plantation Economy of the Spanish Caribbean, 1898-1934. Chapel Hill: University of North Carolina Press, 1999.

. Fighting Slavery in the Caribbean: The Life and Times of a British Family in Nineteenth-Century Havana. Armonk NY: M.E. Sharpe, 1998.

Martinez Heredia, Fernando, Rebecca J. Scott, and Orlando F. Garcia Martinez, eds. Espacios silencios y los sentidos de la libertad: Cuba entre 1878 y 1912. Colección Clio. Havana: Ediciones Unión, Unión de escritores y artistas de Cuba, 2001.

Mason, Michael Atwood. Living Santeria: Rituals and Experiences in an Afro-Cuban Religion. Washington, D.C.: Smithsonian Institution Press, 2002.

May, Ernest R. Imperial Democracy: The Emergence of America as a Great Power. New York: Harcourt, Brace, and World, 1961.

May, Robert. The Southern Dream of a Caribbean Empire. Baton Rouge: Louisiana State University Press, 1973.

McIver, George Wilcox. A Life of Duty: The Autobiography of George Willcox McIver, 1858- 1947. Charleston, SC: History Press, 2006.

Memoria del Primer Centenario de la edificacion y apertura al culto de la ermita, luego parroquia de Nuestra Señora de Monserrat. Habana: Molina y Cía., 1944.

Medel, José Antonio. La Guerra hispano-americana y sus resultados. Havana: P. Fernández, 1929.

Michener, James A. and John Kings. Six Days in Havana. Austin: University of Texas Press, 1989.

Miller, Ivor. Voice of the Leopard: African Secret Societies and Cuba. Jackson: University Press of Mississippi, 2009.

Molinari Calleros, Nylia. La trata de blancas. Buenos Aires: N.P. , 1933.

Moore, Robin. Nationalizing Blackness: Afrocubanismo and Artistic Revolution in Havana, 1920-1940. Pittsburgh, PA: University of Pittsburgh Press, 1997.

Moreno Fraginals, Manuel. Cuba/Espana, Espana/Cuba. Barcelona: Critica, 1996. . El ingenio: Complejo económico-social del azúcar. 2 Volumes. Havana: Editorial de Ciencias Sociales, 1978. 
Morruzzi, Peter. Havana Before Castro: When Cuba was a Tropical Playground. Layton, Utah: Gibbs Smith, 2008

Mueller, John E. War, Presidents, and Public Opinion. New York: Wiley, 1973.

Nace, Ted. Gangs of America: The Rise of Corporate Power and the Disabling of Democracy. San Francisco: Berrett-Koehler Publishers, 2003.

Naranjo Orovio, Consuelo and Armando García González. Medicina y racismo en Cuba: La ciencia ante la inmigración canaria en el siglo XX. Tenerife: Centro de la Cultura Popular Canaria, 1996.

Nash, June and Helen Icken Safa, eds. Sex and Class in Latin America. New York: Praeger, 1976.

. Women and Change in Latin America : New Directions in Sex and Class. Hadley, MA: Bergin and Garvey, 1985.

Navarro, Maria Dolores Gonzalez-Ripoll. Cuba, La Isla de los Ensayos: Cultura y Sociedad, 1790-1815. Madrid: Centro de Humanidades, 1999.

Nicholas, Frederick, ed., McGraw-Hill Electric Railway Manual: The Red Book of American Railway Investments, No. 21, New York: McGraw Publishing, 1914.

Noa, Frederic M. The Pearl of the Antilles: A View of the Past and a Glance at the Future. New York: Knickerbocker Press, 1898.

Nora, Pierre. Realms of Memory: Rethinking the French Past. New York: Columbia University Press, 1996.

Norton, Albert J. Norton's Complete Handbook of Havana and Cuba. Chicago: Rand McNally, 1900.

Offner, John. The Spanish-Cuban-American War and the Birth of American Imperialism, 1895-1902. 2 Volumes. New York: Monthly Review Press, 1972.

An Unwanted War: The Diplomacy of the United States and Spain over Cuba, 1895-1898. Chapel Hill: University of North Carolina Press, 1992.

Opatrny, Josef. U.S. Expansionism and Cuban Annexationism in the 1850s. Lewiston, NY : E. Mellen Press, 1993.

Antecedentes históricos de la formación de la nación cubana. Prague: Universidad Carolina, 1986. 
Ortiz, Fernando. Contrapunteo cubano del tabaco y el azúcar. Havana: Consejo Nacional de Cuba, 1963.

. La tragedia de los Ñáñigos. Habana: Publicigraf, 1993.

. Los brujos negros. Miami: Ediciones Universal, 1973.

Ortiz, Fernando and Alberto N. Pamies. Los brujos negros. Miami: Ediciones Universal, 1973.

Padura Fuentes, Leonardo. El viaje más largo. Havana: Ediciones Union, 1994.

Palmié, Stephan. Wizards and Scientists: Explorations in Afro-Cuban Modernity and Tradition. Duke University Press, 2002.

Pérez, Louis A. Cuba Between Empires, 1878-1902. Pittsburgh: University of Pittsburgh Press,1983.

. Cuba: Between Reform and Revolution. New York: Oxford University Press, 1995.

. Cuba Under the Platt Amendment, 1902-1934. Pittsburgh, PA: University of Pittsburgh, 1991.

. Essays on Cuban History: Historiography and Research. Gainesville:

University Press of Florida, 1995.

On Becoming Cuban: Identity, Nationality, and Culture. Chapel Hill:

University of North Carolna Press, 1999.

. The War of 1898: The United States and Cuba in History and

Historiography. Chapel Hill: University of North Carolina Press, 1998.

. Winds of Change: Hurricanes and the Transformation of Nineteenth-

Century Cuba. Chapel Hill: University of North Carolina Press, 2001.

Perret Ballester, Alberto. El azúcar en Matanzas y sus dueños en La Habana: apuntes e iconografía. Havana: Editorial Ciencias Sociales, 2007.

Pierce, Franklin. Irving J. Sloan, ed. Franklin Pierce, 1804-1868; Chronology, Documents, Biographical Aids. Dobbs Ferry, NY: Oceana, 1968.

Pitkin, Hanna F. Fortune is a Woman: Gender and Politics in the Thought of Niccolò Machiavelli. Berkeley: University of California Press, 1984. 
Portuondo Linares, Serafín. Los Independientes de Color: Historia del Partido Independientes de Color. Havana: Publicaciones del Ministerio de Educación, 1950.

Quétel, Claude. Translated by Judith Braddock and Brian Pike. History of Syphilis. Cambridge: Polity Press, 1990.

Quintero y Almeida, José Mauricio. Apuntes para la historia de la Isla de Cuba con relación a la ciudad de Matanzas desde el año 1693 al de 1877. Matanzas: Imprenta El Ferrocarril, 1878.

Reynolds, Charles B. Standard Guide to Havana: A Complete Handbook for Visitors, with Maps, Illustrations, History, and an English-Spanish Manual of Conversation. Havana: Foster and Reynolds Co., 1905.

. Standard Guide to Havana: A Complete Handbook for Visitors, with Maps, Illustrations, History, and an English-Spanish Manual of Conversation. Havana: Foster and Reynolds Co.,1915.

. Standard Guide to Havana: A Complete Handbook for Visitors, with Maps, Illustrations, History, and an English-Spanish Manual of Conversation. Havana: Foster and Reynolds Co., 1921.

Riera Hernandez, Mario. Ejército Libertador, 1895-1898. Miami: self published, n.d.

Roche Monteagudo, Rafael. La policía y sus misterios. Havana: Imprenta La Prueba, 1908.

Rodgers, Daniel T. Atlantic Crossings: Social Politics in a Progressive Age. Cambridge, MA: Belknap Press, 1998.

Rojas, Rafael . José Martí: La invención de Cuba . Madrid: Editorial Colibri, 2000.

Rojo García, Francisco. Plano de La Habana. Habana: [s.n.], 1951.

Sabater, Miguel Angel. Flores para una leyenda. Havana: Union de Artistas, 2005.

Saco, Jose Antonio. Colección de papeles científicos, históricos, políticos, y de otros ramos sobre la isla de Cuba, Vol II. Paris: Imprenta de d'Aubusson y Kugelmann, 1858.

Sandoval, Mercedes Cros. Worldview, the Orichas, and Santería: Africa to Cuba and Beyond. Gainesville: University Press of Florida, 2006.

Santa Cruz y Mallen, Francisco Xavier de. Historias de Familias Cubanas, Vol I. Havana: Editorial Hercules, 1940. 
Schoeder, Susan. Cuba: A Handbook of Historical Statistics. Boston: G.K. Hall, 1982.

Schoonover, Thomas. Uncle Sam's War of 1898 and the Origins of Globalization. Lexington: University Press of Kentucky, 2003.

Schwartz, Rosalie. Pleasure Island: Tourism and Temptation in Cuba . Lincoln: University of Nebraska Press, 1997.

Scott, Rebecca J. Slave Emancipation in Cuba: The Transition to Free Labor, 18601899. Pittsburgh: University of Pittsburgh Press, 2000.

Silverblatt, Irene. Moon, Sun, and Witches: Gender Ideologies and Class in Inca and Colonial Peru. Princeton, NJ: Princeton University Press,1987.

Simons, Geoff. Cuba: From Conquistador to Castro. New York: St. Martin’s Press, 1996.

Smith, Anthony D. Nations and Nationalism in a Global Era. Cambridge: Polity Press, 2002.

Steffens, Lincoln. The Shame of the Cities. New York: McClure Phillips, 1904.

Stepan, Nancy Leys. The Hour of Eugenics: Race, Gender, and Nation in Latin America. Ithaca, NY: Cornell University Press, 1991.

Stokes, Frederick A. Cartoons of Our War with Spain. New York: F.A. Stokes, 1898.

Stoner, K. Lynn. From the House to the Streets: The Cuban Woman's Movement for Legal Reform, 1898-1940. Durham: Duke University Press, 1991.

Suárez de Tangíl y de Angúlo, Fernando, conde de Vallellano. Nobiliario cubano: o, las grandes familias isleñas, por el conde de Vallellano. 2 Volumes. Madrid: F Beltrán, 1929.

Sublette, Ned. Cuba and its Music: From Drums to the Mambo. Chicago, IL: Chicago Review Press, 2004.

. The World that Made New Orleans: From Spanish Silver to Congo Square. Chicago: Chicago Review Press, 2008.

Tanco Armero, Nicolás. Viaje de Nueva Granada a China y de China a Francia. Paris: Simon Racon, 1861.

Tannahill, Reay. Sex in History. New York: Stein and Day, 1980.

Tarrago, Rafael E. Experiencia de los cubanos en la Cuba Española, 1512-1898. Barcelona: Puvill Libros, 1995. 
Taylor, Henry Louis. Inside a Barrio: A Bottom-up View of Neighborhood Life in Cuba. Sterling, VA: Kumarian Press, 2009.

Terry, T. Philip. Terry’s Guide to Cuba. Boston: Houghton Mifflin, 1927.

Thomas, Hugh. Cuba, Or, The Pursuit of Freedom. New York: Harper and Row, 1971.

Todorov, Tzvetan. The Conquest of America: The Question of the Other. Translated by Richard Howard. New York: Harper and Row, 1984.

Tone, John Lawrence. War and Genocide in Cuba, 1895-1898. Chapel Hill: University of North Carolina Press, 2006.

Turner, Victor. The Ritual Process: Structure and Anti-Structure. Ithaca, NY: Aldine, 1969.

Verrill, A. Hyatt. Cuba of Today. New York: Dodd, Mead and Company, 1931.

Von Humboldt, Alexander. The Island of Cuba: A Political Essay. Princeton: Marcus Wiener Publishers, 2001.

Walkowitz, Judith R. City of Dreadful Delight. Chicago, IL: University of Chicago Press, 1992.

. Prostitution and Victorian Society: Women, Class, and the State. New York: Cambridge University Press, 1980

Wichert, Sabine, and Mary O'Dowd, eds. Chattel, Servant, or Citizen: Women's Status in Church, State, and Society: Papers Read Before the XXIst Irish Conference of Historians. Belfast: Institute of Irish Studies, the Queen's University of Belfast, 1995.

Wilkerson, Marcus M. Public Opinion and the Spanish-American War. Baton Rouge: Louisiana State University Press, 1932.

The World Almanac and Book of Facts. New York: Newspaper Enterprise Association, 1909.

Wright, Irene. Cuba. New York: MacMillan, 1910.

Yarini, Joseph. Come So Far From Havana. Portland, OR: Inkwater Press, 2006.

Yun, Lisa. The Coolie Speaks: Chinese Indentured Laborers and African Slaves of Cuba. Philadelphia, PA: Temple University Press, 2008. 
Zanetti, Oscar, Alejandro Garcia. Translated by Franklin Knight and Mary Todd. Sugar and Railroads: A Cuban History, 1837-1959. Chapel Hill: University of North Carolina Press, 1998.

$\underline{\text { Journal Articles }}$

Armstrong, Karen. "Ambiguity and remembrance: individual and collective memory in Finland.” American Ethnologist, 27, Number 3 (Aug., 2000): 591-608.

Aruca, Lohania, Narciso Menocal, and Edward Shaw. "The Cristobal Colon Cemetery in Havana.” The Journal of Decorative and Propaganda Arts 22 (1996): 36-55.

Baro, Dionisio Poey. "'Race’ and Anti-Racism in Jose Marti’s ‘Mi Raza.” Contributions in Black Studies 12 (1994): 55-67.

Ben-Amos, Avner. "The Sacred Center of Power: Paris and Republican State Funerals.” Journal of Interdisciplinary History. 22, Number 1 (Summer 1991): 27-48.

Bliss, Katherine Elaine. "A Right to Live as Gente Decente: Sex Work, Family Life, and Collective Identity in Early-Twentieth-Century Mexico.” Journal of Women's History 15, Number 4(2004): 164-169.

Bruner, Jerome S. "Myth and Identity.” Daedalus, 88, Number 2, Myth and Mythmaking (Spring 1959): 349-58.

Calvo Pena, Beatriz. "Prensa, politica y prostitucion en La Habana finisecular: El caso de La Cebolla y la 'polemica de las meretrices.”' Cuban Studies 36 (2005): 23-49.

Caulfield, Sueann. "Getting into Trouble: Dishonest Women, Modern Girls, and WomenMen in the Conceptual Language of Vida Policial, 1925-1927.” Signs 19, Number 1 (Autumn 1993): 146-176.

Cluster, Dick and Rafael Hernandez. The History of Havana. New York: Palgrave and Macmillan, 2006.

Companioni Landin, Felix. "Aniversario 99 de la escuela de Cirugia dental en la Habana.” Revista Cubana Estomatal 37, Number 1 (2000): 67-71.

"Continental Policy of the United States - the Acquisition of Cuba." United States Democratic Review 43, issue 1 (April 1859): 2.

Corbitt, Duvon C. "Immigration in Cuba." The Hispanic American Historical Review 22. Number 2 (May 1942): 280-308.

Cruz-Taura, Graciella. "Annexation and National Identity: Cuba’s Mid-NineteenthCentury Debate.” Cuban Studies 27 (1997): 90-106. 
Curtis, James R. and Daniel D. Arreola. "Zonas de Tolerancia on the Mexican Border.” Geographic Review 81, Number 3 (1991): 333-44.

Deere, Carmen Diana. "Here Come the Yankees! The Rise and Decline of United States Colonies in Cuba, 1898-1930.” Hispanic American Historical Review 78, Number 4 (Nov, 1998): 729-765.

de la Fuente, Alejandro. "Race, National Discourse, and Politics in Cuba: An Overview." Latin American Perspectives 25, Number 3 (May 1998): 43-69.

Dworkin y Méndez, Kenya "La patria que nace de lejos: Cuba y lo cubano en la vanguardia de Marti.” Cuban Studies 36 (2005): 1-22.

Finlay, Carlos J. " Anales de la Real Academia de Ciencias Médicas Físicas y Naturales de la Habana 18 (1881). Reprinted in Medical Classics 2 (February, 1938), 147169.

French, William E. "Prostitutes and Guardian Angels: Women, Work, and the Family in Porfirian Mexico, 1876-1911.” Hispanic American Historical Review 72, Number 4 (November 1992): 529-54.

Foyo Martinez-Fortun, J.A. “Apuntes para la historia de la odontologia en Cuba.” Cuadernos de Historia de Salud Publica 23 (1963): 11-85.

Fry, Joseph A. "From Open Door to World Systems: Economic Interpretations of LateNineteenth-Century American Foreign Relations.” Pacific Historical Review 65 (May 1996), 277-303.

. "William McKinley and the Coming of the Spanish-American War: A Study of the Besmirching and Redemption of a Historical Image.” Diplomatic History 3 (Winter 1979), 77-97.

Garwood, Deborah. "Myth as Public Dream: The Metamorphosis of Mary Zimmerman's Metamorphoses." Journal of Performance and Art 25, no. 1 (January 2003): 69-78.

Goldstein, Robert Justin. “Political Funerals.” Society 21, no. 3 (March-April 1984): 1317.

Guy, Donna J. "White Slavery, Public Health and the Socialist Position on Legalized Prostitution in Argentina, 1913-1936. ” Latin American Research Review 23, Number 3 (1988): 60-80. 
Helg, Aline. "Black Men, Racial Stereotyping, and Violence in the U.S. South and Cuba at the Turn of the Century.” Comparative Studies in Society and History 42, Number 3 (July 2000): 576-604.

Hennessy, Alistair. “The Roots of Cuban Nationalism.” Journal of International Affairs 39, no. 3 (July 1963): 345-59.

Isabello, Liliana Graciela. “La prostitución y la trata de blancas: 1874-1886.” Todo es História 18, Number 223 (November 1985): 83-92.

Kiple, Kenneth F. “Cholera and Race in the Caribbean.” Journal of Latin American Studies 17 (May, 1995): 157-77.

Knight, Franklin W. "Origins of Wealth and the Sugar Revolution in Cuba." Hispanic American Historical Review 57, Number 2 (May, 1977): 231-253.

Kumar Katyal, Neal. "Men Who Own Women: A Thirteenth Amendment Critique of Forced Prostitution.” Yale Law Journal 103, Number 2 (1993): 791-826.

Lewis, Naphtali. "Leitourgia and Related Terms." Greek, Roman and Byzantine Studies 3 (1960): 175-84.

. "Leitourgia and related terms,(II)." Greek, Roman and Byzantine Studies 6 (1965): 226-30.

Magnússon, Sigurdur Gylfi. "The Singularization of History: Social History and Microhistory within the Postmodern State of Knowledge.” Journal of Social History 36, Number 3 (Spring, 2003): 701-735.

Martínez-Fernández, Luis. "Life in a "Male City: Native and Foreign Elite Women in

Meylin de la O Torres, Ana and Adrián López. "José Antonio Cortina: muerte civil, prensa y patriodrama.” Debates Americanos 4 (November-December, 1997): 147-152.

Mirabal, Nancy Raquel. "The Afro-Cuban Community in Ybor City and Tampa, 18861910.” OAH Magazine of History 7, Number 4 (Summer 1993): 19-22.

O’Connel Davidson, Julia. “Sex Tourism in Cuba.” Race and Class 38, Number 1 (1996): 39-50.

Oglesby, J.C.M. “The Cuban Autonomist Movement’s Perception of Canada, 18651898: Its Implication.” The Americas 47, Number 4 (April 1992): 445-61.

Pacheco, Roberto. “Fortune is a Woman.” Atlantic Millennium Journal, Vol. 2 (1994): 133-147. 
Patterson, Thomas G. "United States Intervention in Cuba, 1898: Interpretations of the Spanish-American-Cuban-Filipino War.” History Teacher 29 (May 1996) 341-61.

Pérez, Jr. Louis A. "Between Baseball and Bullfighting: The Quest for Nationality in Cuba, 1868-1898." Journal of American History 81, Number 2 (September 1994): 493-518.

"The Collapse of the Cuban Planter Class.” Inter-American Economic Affairs 36, Number 3 (Winter 1982): 3-22.

Poyo, Gerald. "Evolution of Cuban Separatist Thought in émigré Communities of the United States, 1848-1895.” Hispanic American Historical Review 66, Number 3 (Aug 1986): 485-507.

Puig, Washington Rosell and Ena Paneque Ramos. Evolución histórica de la enseñanza de la Anatomía en Cuba. Havana: Facultad de Ciencias Médicas "Dr. Enrique Cabrera," 30 March 2007.

Santamarina, Juan C. "The Cuba Company and the Expansion of American Business in Cuba, 1898-1915.” Business History Review 74, Number 1 (Spring, 2000): 4183.

Scott, Rebecca J. "Small-Scale Dynamics of Large-Scale Processes." American Historical Review 105, Number 2 (2000): 472-79.

Seal, Graham. "The Robin Hood Principle: Folklore, History and the Social Bandit.” Journal of Folklore Research 46, Number 1 (January-April, 2009): 67-87.

Shelton, Raúl M. Cuba y su cultura. Miami: Ediciones Universales, 1993.

Silva, Eugenio. "Contribution of the Americas to the War and to Peace." Annals of the American Academy of Political and Social Science 228 (July 1943): 21-24.

Simons, Geoff. Cuba: From Conquistador to Castro. New York: St. Martin’s Press, 1996.

Smith, Lois M. and Alfred Padula. "Twenty Questions on Sex and Gender in Revolutionary Cuba.” Cuban Studies 18 (1988): 149-58.

Somner, Doris. Foundational Fictions: The National Romances of Latin America. Berkeley: University of California Press, 1993.

Stoner, K. Lynn. "Book Review, Reyita: The Life of a Black Cuban Women in the Twentieth Century.” The Americas 58, Number 4 (April 2002), 653-55. 
Tarrago, Rafael E. "The Road to Santiago: Cuban Separatism and United States Americanism and How They Converged in 1898.” Iberoamericana, Nueva época, 3 (2001): 61-89.

Winslow, E. de Forest. “A Glimpse of Havana.” Domestic Engineering and Journal of Mechanical Contracting 48, Number 864 (3 July 1909): 47-49.

Wisan, Joseph E. The Cuban Crisis as Reflected in the New York Press, 1895-1898. New York: Columbia University Press, 1934.

Van Norman, William C. "The Process of Cultural Change Among Cuban Bozales During the Nineteenth Century.” The Americas, 62, Number 2 (October 2005), 177-207.

Dissertations and Theses

González, María del Carmen. "La cultura popular en el drama cubano del siglo XX.” Ph.D. Dissertation, University of Florida, 1984.

\section{$\underline{\text { Book Chapters }}$}

Caulfield, Sueann. "The Birth of Mangue," in Daniel Balderston and Donna Guy, eds., Sex and Sexuality in Latin America. New York: New York University Press, 1997.

de Santis, Hugh. “The Imperialistic Impulse and American Innocence, 1865-1900.” In American Foreign Relations: A Historiographical Review. Gerald K. Haines and Samuel Walker, eds. Westport, CT: Greenwood Press, 1981.

Di Liscia, María Herminia, María Silvia Di Liscia, and Ana María Rodríguez "Prostíbulos y control estatal en el Territorio Nacional de la Pampa." In Lidia Knecher and Marta Panaia, eds. La mitad del país: La mujer en la sociedad argentina. Buenos Aires: Centro Editor de América Latina, 1994.

Diodati, Lilian. "Prostitutas, burdeles y reglamentos en la ciudad de Colón (Provincia de Buenos Aires)," In La mitad del país: La mujer en la sociedad argentina. Lidia Knecher and Marta Panaia, eds. Buenos Aires: Centro Editor de América Latina, 1994.

Espinosa, Mariola. “A Fever For Empire: U.S. Disease Eradication in Cuba As Colonial Public Health.” In Alfred W. McCoy and Francisco Scarano, ed. Colonial Crucible: Empire in the Making of the Modern U.S. State. Madison: University of Wisconsin Press, 2009. 
Guy, Donna J. “Prostitution and Female Criminality in Buenos Aires, 1875-1937.” In Lyman L. Johnson, ed. The Problem of Order in Changing Societies: Essays on Crime and Policing in Argentina and Uruguay, 1750-1940. Albuquerque: University of New Mexico Press, 1990.

Halbwachs, Maurice. On Collective Memory. Chicago: University of Chicago Press, 1992.

Helg, Aline. "Race in Argentina and Cuba, 1880-1930: Theory, Policies, and Popular Reaction.” In Richard Graham, ed. The Idea of Race in Latin America, 18701940. Austin: University of Texas Press, 1990.

Iglesias, Marial. “José Martí: mito legitimacion y simbolo.” In Diez nuevas miradas a la historia de Cuba,. Edited by Jose A. Piqueras. Castello de la Plana, Spain: Universitat Jaume I, 1998.

Levi, Giovanni. “On Microhistory.” In New Perspectives on Historical Writing, Peter Burke, ed. Cambridge: Polity Press, 1991.

Lavrín, Asunción. "Suffrage in South America: Arguing a Difficult Case.” In Caroline Daley and Melanie Nolan, eds. Suffrage and Beyond: International Feminist Perspectives. New York: New York University Press, 1994.

Lorini, Alessandra. "Social Scientists Wrestling with Race and Nation: A Transnational Perspective on African-American W.E.B. Du Bois and Cuban Fernando Ortiz.” In Alessandra Lorini, ed, An Intimate and Contested Relation: The United States and Cuba in the Late Nineteenth and Early Twentieth Centuries. Florence: Firenze University Press, 2005.

Moore, Robin. “Afrocubanismo and Son.” In The Cuba Reader: History, Culture, Politics. Aviva Chomsky, Barry Carr, Pamela María Smorkaloff, edtiors. Durham: Duke University Press, 2004.

Nearing, Scott. "The Beginnings of World Dominion.” In The American Empire. New York: Rand School of Social Science, 1921.

Roche Monteagudo, Rafael. "Proxelestes.” In La policia y sus misterios. Havana: Imprenta La Prueba, 1908.

Sundquist, Eric. "Slavery, Revolution, and the American Renaissance." In Walter Benn Michaels and Donald E. Pease, eds. The American Renaissance Reconsidered. Baltimore, MD: Johns Hopkins Press, 1989.

Utset, Marial Iglesias. "Imágenes en Conflicto: Cuba y la presencia imperial norteamericana (1898-1902)." In An Intimate and Contested Relation: The United States and Cuba in the Late Nineteenth and Early Twentieth Centuries. Alessandra Lorini, ed. Florence: Firenze University Press, 2005. 
Vázquez, Manuel Salvador. "Morbimortalidad colérica en Cuba: la epidemia de 1833 y la permanencia de la enfermendad en la isla (1834-1835)." In Enfermedad y muerte en America y Andalucía, siglos xvi- $x x$. Seville: Escuela de Estudios Hispanoamericanos, 2004.

Bibliographies

Venzon, Anne Cipriano. The Spanish American War: An Annotated Bibliography. New York: Garland, 1990.

\section{Dictionaries}

Bowker, John Westerdale . Oxford Dictionary of World Religions. Oxford: Oxford University Press, 1997.

Diccionario de la lengua española. Madrid: Espasa-Calpe, 2005.Http://www.wordreference.com. Accessed 9 January 2011

Marshall, Gordon, ed. Concise Oxford Dictionary of Sociology. Oxford University Press, 1994.

\section{Other Sources}

Anonymous. Juan Banal posting. $\underline{H}$-Latam@h-net.msu.edu. 28 February 2002.

Beers, Mayra and Roberto Pacheco. "Damsels, Apes and Pickanninies.” Unpublished manuscript in possession of the author, 2000.

Bronfman, Alejandra. "Unsettled and Nomadic: Law, Anthropology and Race in Twentieth-Century Cuba." Latin American Studies Center, University of Maryland, Working Paper No. 9 (2002), 42.

Canova, Leon J. Cuba: A Pamphlet Descriptive of the Island of Cuba Containing Unembellished Data for General Information. Havana: n.p., 1910.

Clásicos del Son, Jóvenes. “Un Chulo en la Habana.” Fruta Bomba. Tumi Música Ltd., 2006.

Daranas, Ernesto, writer/director. Los Dioses Rotos. Havana, ICAIC-MINCULT, 2008. Http://www.cubacine.cu/losdiosesrotos. Accessed 15 August 2010.

. La Vida en Rosa. Teatro Buendía (Havana), Hemispheric Institute Digital Video Library, NYU Libraries. Http://hidvl.nyu.edu/video. Accessed 15 August 2010. 
Directorio Comercial y Oficial de Cuba, Puerto Rico, y las demas Antillas, inclusas las Bermudas para el ano 1901. New York: The Spanish American Directories Company, 1901.

Espinosa Dominguez, Carlos, director. Requiem por Yarini. Teatro Cubano

Contemporaneo: Antologia. Madrid: Fondo de Cultura Economica, 1992.

Leviston, Frances. “Scandinavia.” In Public Dream. London: Picador, 2007

Requiem por Yarini. Havana, Cine Internacional Production, 2001.

$\underline{\text { Internet Sources }}$

“Acera de Louvre.” University of Miami Libraries. Cuban Heritage Collection. Cuban Postcard Collection. Collection CHC0359.

Http://www.flickr.com/photos/umdigital/4457063651/ Acccessed 15 January 2011.

Albriza, Virgilio Companioni. "La oposición a la enmienda Platt en la caricature política de la epoca (1899-1902).” Monografias.com. Http://www.monografias.com/trabajos55/oposicion-enmienda-platt/oposicionenmienda-platt.shtml. Accessed 20 August 2010.

Buchanan, James, J. Y. Mason and Pierre Soule. “The Ostend Manifesto.” House Executive Documents. 33 Cong., 2 Sess., Vol. X, 93. Http://xroads.virginia.edu/ hyper/hns/ostend/ostend.html. Accessed 20 March 2003.

“Castro Warns young Cubans of U.S. annexationist aims.” 16 August 2007, Agencia EFE, Http://news.notiemail.com, November 16, 2009.

Catalogue of officers and graduates of Columbia university from the foundation of King's college in 1754, (page 81 of 107). Accessed 17 September 2010.

Cram, George F. “Havana 1901.” In Cram's Modern Atlas. Chicago: n.p., 1901. Digitized map. Perry-Castañeda Library Map Collection, Historical Maps of the Americas. Http://www.lib.utexas.edu/maps/historical/havana_harbor_1901.jpg. Accessed14 December 2010).

Ellis Island Foundation, Http://www.ellisisland.org/search/passRecord.asp. Accessed 6 September 2010.

Garcia, Delgado G. "Hospital Clínico Quirúrgico Docente General Calixto Garcia, Recuento Histórico en su centenario.” Boletín Hospital Docente "General. Calixto García 13-14 numero1-2 (1998- 1999): 57-60. Http://www.sld.cu/uvs. Accessed 25 August 2010. 
Grant, Ulysses S. Second State of the Union Address, 5 December 1876; State of the Union Address 1793-2011, Http://stateoftheunionaddress.org/category/ulysses-sgrant. Accessed 27 July 2010.

“Habanera de Cuba,” n.d. Colección Cancionera, La Tuna, Http://tuna.upv.es. Accessed 2 October 2010.

Havana, Central Park, Capitol, Inglaterra Hotel.” Online images, Flickr.com. Http://www.flickr.com/photos/9teen87/3523094419/. Accessed 15 January 2011.

“Havana’s Muelle de Luz” Digitized photograph. Image posted by QUANG, 22 July 2009. Cultureforum.net. Http://secretoscuba.cultureforum.net/t14434-fotos-decuba-solamentes-de-antes-del-1958. Accessed 14 December 2010.

Hawn, Jerry. “The Funeral of George Washington.” Mall Times. September 2007. Http://www.nps.gov/mall/parknews/upload/MallTimes1.pdf. Accessed 9 January 2011.

Kestenbaum, Lawrence. "Politicians who died of Cholera, William Shaler.” Political Graveyard: A Database of Historic Cemeteries. Http://politicalgraveyard.com/death/cholera.html. Accessed 24 August 2010.

Klupfel, José Yarini, “Relación de Cólera, 1833,” “Cólera en el ingenio.” Online translation into English. Http://www.thefullwiki.org/wiki//C\%C3\%B3lera_en_el_Ingenio. Accessed 25 June 2009.

Larrea, Ramón Fernández. “Carta a Yarini.” Encuentro 24 (Spring 2002): 125-128. Http://www.cubaencuentro.com/revista/revista-encuentro/archivo/24-primaverade-2002/presentacion-24. Accessed 14 March 2009.

Machado Ruiz, Manuel. “Cualquiera Canta un Cantar.” Poetas Andaluces.com. Http://artespoeticas.librodenotas.com/artes/1195/cualquiera-canta-un-cantar-1919. Accessed 10 October 2010.

Massetti, Santiago. "El origen de la religiosidad del cubano: El que no tiene de congo, tiene de carabalí.” Agencia Periodística Mercosur (8 June 2010). Http://www.prensamercosur.com.ar/apm/nota_completa.php. Accessed 15 September 2010 .

“Morro Castle.” Ellis Island Foundation, Ellis Island Ship Database. Http://www.ellisisland.org/search/passRecord.asp/letter=m\&half=2\&sname=Morr o*Castle. Accessed September 6, 2010.

"Nicolo Machiavelli." Stanford Encyclopedia of Philosophy Online. Http://plato.stanford.edu. Accessed October 21, 2009. 
Peregrin, Marjorie and Teresa de Jesus Torres. "Fundamentos y esencias en un acto de recordación.” Noticias Habana Patrimonial, Dirección de Patrimonio Cultural, 27 (November, 2007). Http://www.ohch.cu/noticias. Accessed 21 September 2010.

Rivas Agüero, Miguel A. "Velorios y entierros en el viejo Camaguey.” Originally published in Maria Antonia Crespí, ed. El Camagüeyano (October 1987). Online reprint in Victor Romero Soñora, "Recuerdos de Camagüey.” 23 October 2009. Http://lagacetadepuertoprincipe.com/2009/10/velorios-y-entierros-en-elviejo.html. Accessed, 12 November 2009.

Sánchez, Martha. "Laura Alonso, maestra de todos.” In Cubasi.com, online journal. Http://www.cubasi.cu/desktopdefault.aspx?spk=160\&clk=44485\&lk=1\&ck=2237 2\&spka=35. Accessed 28 January 2007.

Taylor, J. "Protector of Freedom, 1898.” Digitized cartoon image. University of North Carolina at Greensboro.

Http://www.uncg.edu/ jwjones/world/visualtours/cubacartoons/cubacartoon10.ht ml. Accessed 25 August 2010.

Valdes, Gustavo. "Venezuelan TV Shows Exhumed Skeleton of Former Military Leader.” CNN.com, 17 July 2010. Http://articles.cnn.com/2010-07-17/world. 
VITA

\section{MAYRA BEERS}

1974

1991

1991 - 1994

1994 - 1995

1995

1996 - 1998

$1996-1998$

1997

1999

2000
A.A.

Miami-Dade College

Miami, Florida

B.A., Biblical Studies

Miami Christian College/Trinity International University

Miami, Florida

Middle School Teacher

King's Christian School

Miami, Florida

Teaching Assistant

Florida International University

Miami, FL

M.A., History

Florida International University

Miami, Florida

Mellon Doctoral Fellow in Caribbean Studies

Florida International University

Miami, Florida

Editor, Atlantic Millennium

Florida International University

Miami, Florida

Jay I. Kislak Foundation Prize in History and Anthropology

Jay I. Kislak Foundation

Miami Springs, FL

Latin American and Caribbean Studies Certificate

Florida International University

Miami, Florida

African-New World Studies Certificate

Florida International University

Miami, Florida 
James R. Scobie Memorial Award

American Historical Association (AHA)

Conference on Latin American History (CLAH)

$2001-2009$

Director of Operations and Associate Corporate Secretary Board of Trustees, Florida International University Miami, FL

$2006-2009$

Chief of Staff, Office of the President

Florida International University

Miami, FL

2005 - present

Director of Operations, FIU Center for Leadership

Florida International University

Miami, FL

\section{PUBLICATIONS AND PRESENTATIONS}

Beers, M. (1995). The Economics of Bigotry: The Spanish Black Legend and the Power of Illustrated Works. The Atlantic Millennium, 3 (1995):99-120.

Beers, M. (2003). Murder in San Isidro: Politics of Gender in Republican Cuba, 19001910. Cuban Studies, 34 (2003): 97-129.

Beers, M. (January, 1999). Murder in San Isidro: Gender, Society, and Prostitution in Cuba. Paper presented at the American Historical Association Annual Meeting, Washington, D.C.

Beers, M. (January, 2009). Para Subsistir Dignamente: Manhood and Cubanidad in Neo-Republican Cuba. Paper presented at the meeting of the Conference of Latin American historians, New York City, New York.

Beers, M. (March 2003). Death and Dying in Republican Havana,1900-1910. Paper presented at the Phi Alpha Theta Colloquium, Miami, FLorida.

Beers, M. (March, 1996). Peddling the Gospel: Alonso de Sandoval's Merchant Initiatives in Seventeenth-century Cartagena. Paper presented at the meeting of the Phi Alpha Theta Regional Conference, Tampa, Florida. Winner of the Best Paper Award.

Beers, M. (October, 2002). El Velorio Cubano: Private Mourning, Public Funerals. Paper presented at the Cuban Research Institute Biannual Conference, Miami, Florida.

Beers, M., and Pacheco, R. (1998). Damsels, Apes and Pickanninies: Cartoon Images of Cuba in the U.S. Press, 1896-1906. Paper presented at the Graduate Student Conference, Miami, Florida. 